\author{
Universidade de São Paulo \\ Escola Superior de Agricultura "Luiz de Queiroz" \\ Centro de Energia Nuclear na Agricultura
}

\title{
Um estudo diagnóstico da Educação Ambiental nas Escolas do Ensino Fundamental do Município de Piracicaba/SP
}

\section{Júlia Teixeira Machado}

Dissertação apresentada para a obtenção do título de Mestre em Ecologia Aplicada

\section{Piracicaba}


Júlia Teixeira Machado

Bacharelado e Licenciatura Plena em Ciências Biológicas

Um estudo diagnóstico da Educação Ambiental nas Escolas do Ensino Fundamental do Município de Piracicaba/SP

Orientadora:

Prof ${ }^{a}$. Dra. LAURA ALVES MARTIRANI

Dissertação apresentada para a obtenção do título de Mestre em Ecologia Aplicada

\section{Piracicaba}




\author{
Machado, Júlia Teixeira \\ Um estudo diagnóstico da Educação Ambiental nas Escolas do Ensino Fundamental \\ do Município de Piracicaba/SP. - - Piracicaba, 2007. \\ 194 p. : il. \\ Dissertação (Mestrado) - - Escola Superior de Agricultura Luiz de Queiroz. Centro de \\ Energia Nuclear na Agricultura, 2007. \\ 1. Educação ambiental 2. Ensino fundamental 3. Escolas 1. Título
}

$\operatorname{CDD} 333.707$

"Permitida a copia total ou parcial deste documento, desde que citada a fonte - O autor? 
Dedico esse trabalho à minha querida familia, companheiros de minha vida...

Aos meus amados pais, Janet e José, aos irmãos, Joana e Virgilio, ao meu cunhado Júnior, as minhas queridas avós, Hilda e Armelinda e aos saudosos avôs, Oswaldo e Antônio, tios, primos e, em especial, aos meus sobrinhos, Davi, João e Helena.

Pelo amor de hoje e sempre! 


\section{AGRADECIMENTOS}

À Laura, pela atenção, dedicação, orientação e, sobretudo, por ter acreditado em meu potencial.

À Denise e à Maria Elisa, pelas conversas, críticas e sugestões que foram essenciais para o enriquecimento dessa pesquisa.

Aos meus amigos, pelo apoio, convivência e idéias compartilhadas, em especial à Raquel, à Flávia, ao Hélio, ao Lúcio e à Márcia.

À minha família, pela participação irrestrita nessa jornada, em especial ao meu pai, pela profunda dedicação com que revisou esse trabalho; ao meu irmão, pela paciência e auxílios técnicos; e a minha irmã e meu cunhado, pela ajuda na tradução do resumo.

Aos professores, coordenadores, diretores e funcionários das escolas de ensino fundamental de Piracicaba, pela gentileza e atenção com que me receberam em suas escolas. Sou eternamente grata a esses educadores que colaboraram com a realização dessa pesquisa. 


\section{SUMÁRIO}

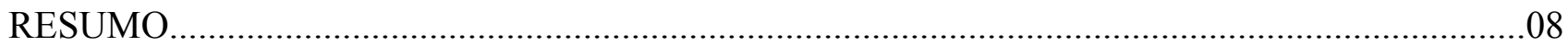

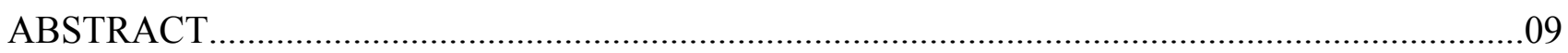

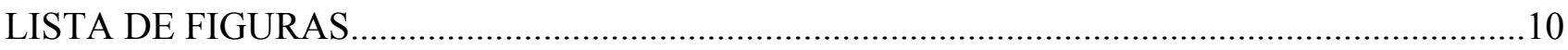

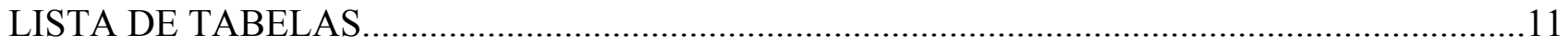

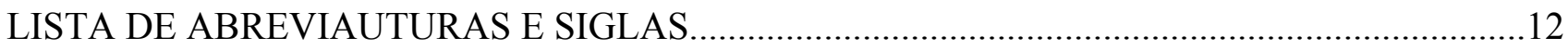

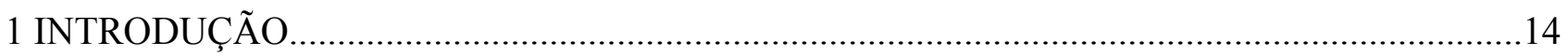

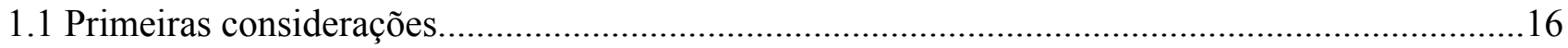

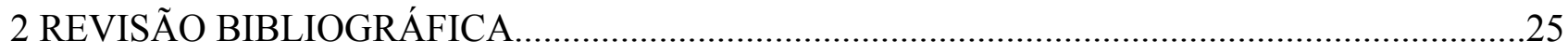

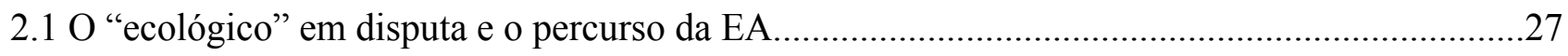

2.1.1 As políticas públicas nacionais de Educação Ambiental..............................................................34

2.2 As diferentes correntes da Educação Ambiental: uma diversidade de olhares e fazeres expressas

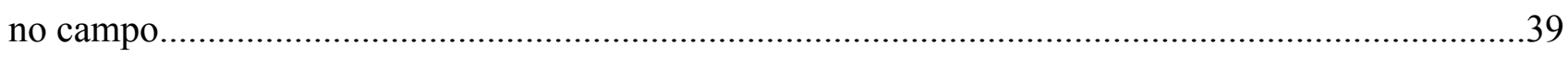

2.3 A Educação Ambiental e suas especificidades: em defesa de uma educação que seja

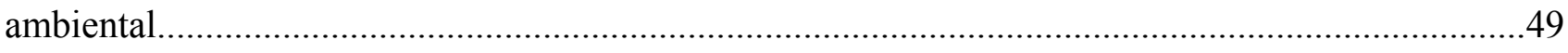

2.3.1 Situando a Educação Ambiental no Ensino Formal: possibilidades e limites.............................52

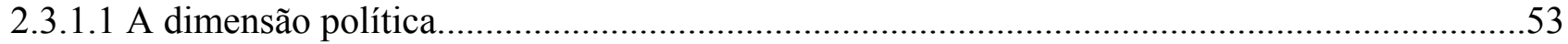

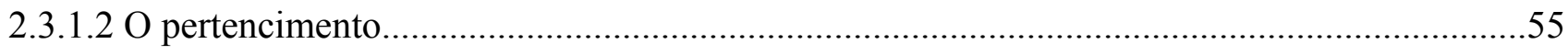

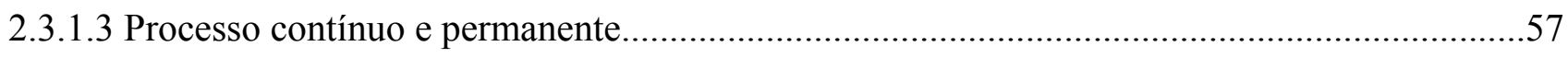

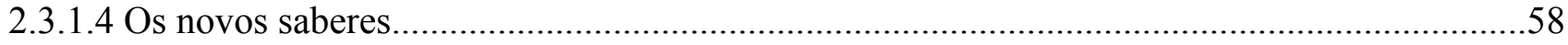

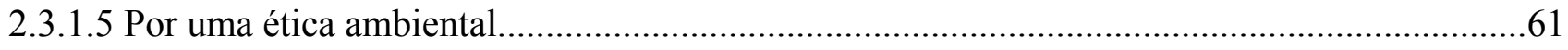

2.3.1.6 O princípio da interdisciplinaridade ...............................................................................64

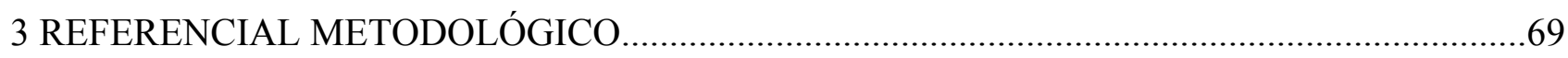

3.1 A pesquisa científica e a crise de paradigmas...........................................................................69

3.2 A pesquisa em Educação Ambiental....................................................................................

3.2.1 A trajetória da pesquisa....................................................................................................

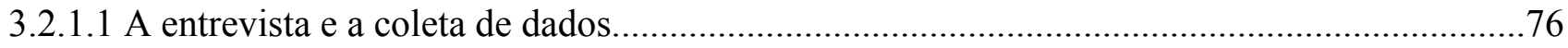

3.2.1.2 Método de análise e interpretação dos dados......................................................................77

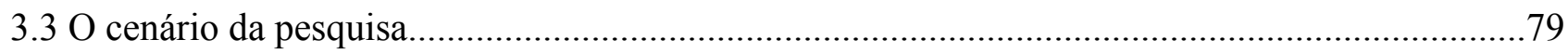




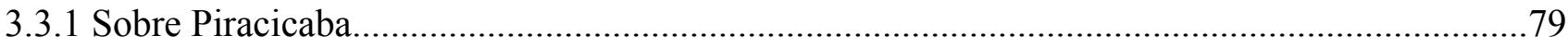

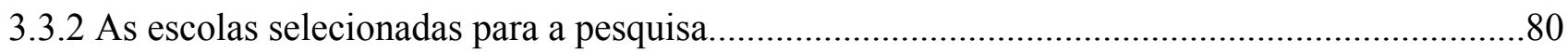

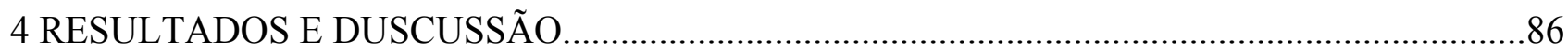

4.1 Os professores que trabalham com educação ambiental...............................................................87

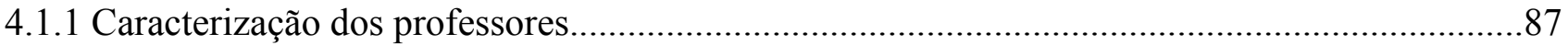

4.1.2 A motivação dos professores para trabalhar com Educação Ambiental.......................................96

4.1.3 Como a Educação Ambiental tem chegado aos professores.......................................................99

4.1.3.1 A formação dos professores em Educação Ambiental..........................................................104

4.2 As concepções de Educação Ambiental dos professores entrevistados: tendências

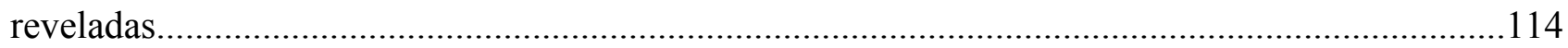

4.3 A incorporação da Educação Ambiental na escola de ensino fundamental...................................122

4.3.1 A Educação Ambiental na prática dos professores: a incorporação da temática ambiental no

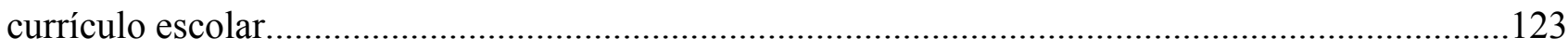

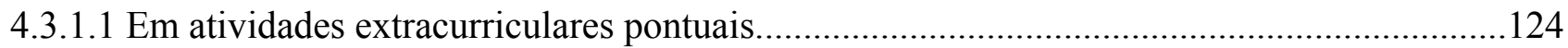

4.3.1.2 Dentro dos conteúdos programados das disciplinas.............................................................125

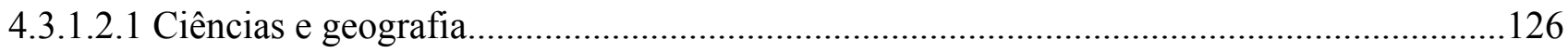

4.3.1.2.1.1 Conteúdos que os professores de Ciências e Geografia relacionam com Educação

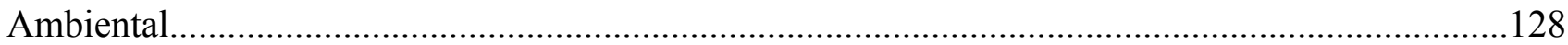

4.3.1.2.2 Conteúdos que os professores de Artes, Matemática e Português relacionam com Educação Ambiental.

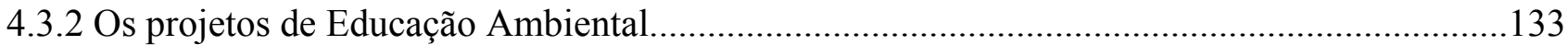

4.3.2.1 Os projetos de Educação Ambiental desenvolvidos pelas escolas..........................................134

4.3.2.2 Os projetos de Educação Ambiental desenvolvidos em parcerias/orientação externa. .136

4.3.2.3 A elaboração dos projetos de Educação Ambiental................................................................143

4.3.2.3.1 Quem escreve os projetos de Educação Ambiental..............................................................143

4.3.2.3.2 Os objetivos e as estratégias dos projetos de Educação Ambiental.....................................145

4.3.2.3.3 A abrangência dos projetos de Educação Ambiental: as disciplinas e séries

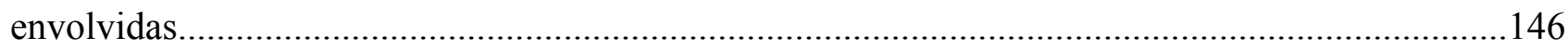

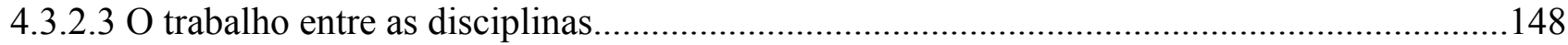

4.3.3 Os recursos utilizados com os trabalhos de Educação Ambiental................................................152 


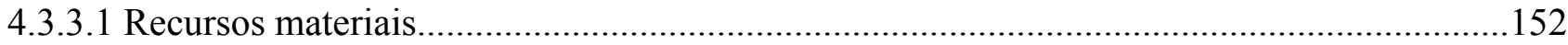

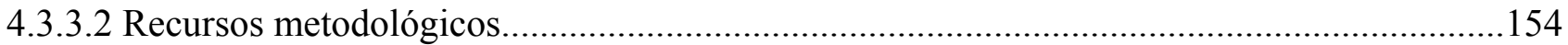

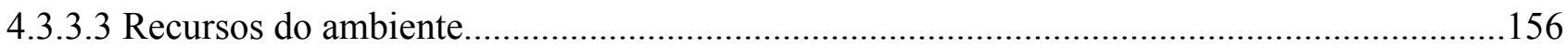

4.3.4 As carências e dificuldades nos trabalhos com Educação Ambiental na escola......................160

4.3.4.1 As dificuldades encontradas pelos professores quando trabalham com Educação

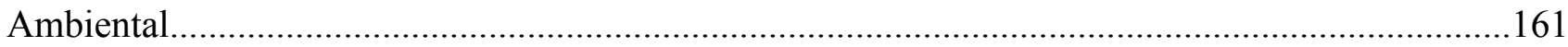

4.3.4.1.1 Em relação à estrutura escolar..................................................................................162

4.3.4.1.2 Os conteúdos programados e materiais didáticos....................................................165

4.3.4.1.3 Em relação à motivação e comprometimento.............................................................167

4.3.4.1.4 Em relação à formação dos professores.......................................................................169

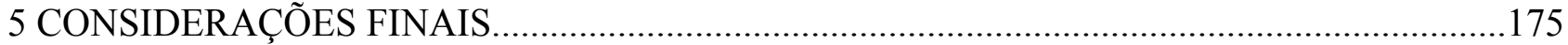

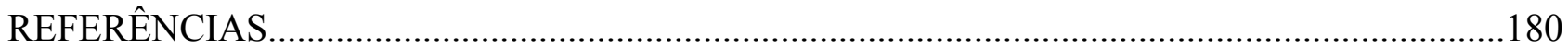

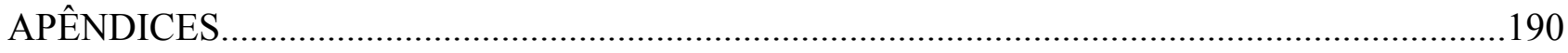




\section{RESUMO}

\section{Um estudo diagnóstico da Educação Ambiental nas Escolas do Ensino Fundamental do Município de Piracicaba/SP}

O presente trabalho teve o objetivo de realizar um estudo diagnóstico do modo como a Educação Ambiental vem sendo trabalhada nas escolas de ensino fundamental ( $5^{\mathrm{a}}$ a $8^{\mathrm{a}}$ séries) da cidade de Piracicaba/SP. A pesquisa levantou os professores que trabalham com Educação Ambiental nas escolas, as principais atividades desenvolvidas, os objetivos, as experiências vivenciadas, os materiais utilizados, as metodologias empregadas, os projetos desenvolvidos e parceiros nessas atividades. Além disso, procurou identificar as concepções de Educação Ambiental dos professores, bem como as principais carências e dificuldades na realização das atividades. $\mathrm{O}$ estudo do modo como vem se dando as práticas de Educação Ambiental nas escolas é pertinente por se tratar de um parâmetro curricular recente, desenvolvido muitas vezes de forma improvisada e adaptada, outras vezes por pessoas e instituições externas às escolas. A presente pesquisa, utilizandose de elementos da pesquisa qualitativa, realizou entrevistas junto aos coordenadores e professores das escolas estaduais e particulares do ensino fundamental e reuniu informações das estruturas escolares. A cidade de Piracicaba conta com um pouco mais do dobro de escolas de ensino fundamental da rede estadual (cinqüenta e quatro) em relação às escolas da rede privada (vinte). Para garantir que a amostra fosse representativa e proporcional, o município foi dividido em quatro regiões geográficas, sendo que em cada uma delas foram sorteadas as escolas para a realização da pesquisa, de modo que se selecionou um sexto das escolas estaduais e um terço das escolas particulares da cidade. Na dissertação demonstramos que as dificuldades, tanto das escolas estaduais quanto das particulares, são referentes às diferentes formas de interpretar e compreender a Educação Ambiental, aspectos esses relacionados ao fato de se tratar de um campo ainda novo e não devidamente incorporado nos processos de formação de professores. Além disso, observamos como agravantes a falta de tempo e espaço adequado para reuniões de planejamento, estudo e pesquisa, recursos materiais e metodológicos escassos e até inexistentes, currículos programados de modo rígido e fechado, organizados por uma estrutura fortemente disciplinar. Observamos que a Educação Ambiental vem sendo trabalhada nas escolas em disciplinas consideradas "ambientais", como Ciências e Geografia, com o desenvolvimento de projetos temáticos ou em atividades extracurriculares e pontuais. Pôde-se constatar que a Educação Ambiental vem sendo incorporada pelas escolas de maneira fragmentada, superficial, isolada e descontínua, portanto, contribuindo pouco para uma educação escolar que almeje ser crítica, transformadora e emancipatória.

Palavras-chave: Educação Ambiental; Escola; Ensino fundamental; Crise ambiental 


\section{ABSTRACT \\ A diagnosis study of the Environmental Education in the elementary schools of the city of Piracicaba/SP}

The present work has had the goal to do a diagnosis study about the way the Environmental Education has been working in the elementary schools $\left(5^{\text {th }}\right.$ to $8^{\text {th }}$ grades) of the city of Piracicaba/SP. The research mapped the teachers who work with environmental education at schools, their main activities that were developed, goals, experiences, used materials, and applied methodologies, developed projects and partners in these activities. Moreover, this research tried to identify the concepts of environmental education of these teachers as well as their main needs and difficulties in performing their activities. The study of the environmental education in the schools is important since it has recently become part of the curriculum, many times developed as an improvising and adapted way, and other times for people or institutions out of the schools. This research, using elements from the qualitative research, promoted interviews with state and private elementary schools coordinators and teachers, and collected information regarding schools structures. The city of Piracicaba has more than twice the number of state elementary schools (it has fifty four) than private schools (twenty). In order to guarantee a representative and proportional sample, the city was divided in four geographic regions, being schools randomly selected in each region for the purpose of the research, with the result of one sixth of the state schools being selected versus one third of private schools. In the dissertation we demonstrate that the difficulties, in both state and private schools, were due to the multiple ways to interpret and comprehend environmental education. These aspects related to the different concepts and goals of environmental education. Other difficulties refer to the fact that environmental education is a new subject and so far not well incorporated in the process of training teachers. Besides, we observed as an additional contribution the lack of time and adequate space to plan meetings, study and research, few or none material and methodological resources, firm and defined school programs, organized by a very rigid and disciplined structure. We also observed that the environmental education has been working at schools in disciplines considered in connection with environment, as science and geography, with the development of theme projects or in extra school program and specific activities. It has been found out that environment education has been incorporated by schools in isolated, superficial, discontinued and piecemealed way, and therefore, with a low contribution to a school education which aims to develop thinking, transformation and emancipation.

Keywords: Environmental education; School; Elementary school; Environmental crisis 


\section{LISTA DE FIGURAS}

Figura 1 - A tipologia dos paradigmas educativos na Educação Ambiental (Bertrand \& Valois, 1992).

Figura 2 - Tipologia das concepções do Desenvolvimento Sustentável na Educação Ambiental Calgary Latin American Studies Group (1994).

Figura 3 - A tipologia das concepções sobre o ambiente na Educação Ambiental (SAUVÉ, 1992, 1994).

Figura 4 - Mapa do município de Piracicaba dividido em regiões geográficas. 82

Figura 5 - Porcentagem entre diretores, coordenadores e professores entrevistados para pesquisa....83

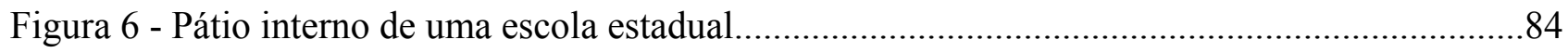

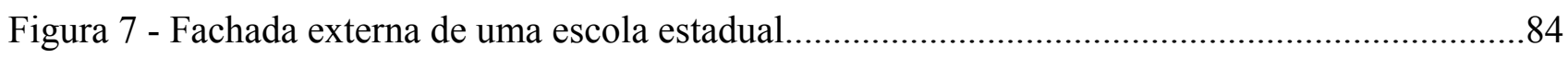

Figura 8 - Porcentagem de professores pertencentes as rede estadual e privada de ensino................87

Figura 9 - Porcentagem de mulheres e homens participantes da pesquisa.....................................88

Figura 10 - Distribuição etária dos participantes da pesquisa. .....................................................89

Figura 11 - Tempo de magistério dos professores envolvidos na pesquisa. .................................91

Figura 12 - Tempo de permanência dos professores nas escolas onde foram entrevistados. .............94

Figura 13 - Disciplinas que os professores entrevistados lecionam..........................................95

Figura 14 - Coletores de lixo seletivos de uma escola estadual...............................................137

Figura 15 - Pnues reutilizados como canteiros de flores em uma escola particular........................137

Figura 16 - Cartazes sobre reciclagem expostos no corredor de uma escola estadual....................159

Figura 17 - Sucateca de uma escola particular...................................................................... 159

Figura 18 - Dificuldades citadas pelos professores entrevistados ao se trabalhar com Educação Ambiental 


\section{LISTA DE TABELAS}

Tabela 1 - Instituições de Ensino Superior cursados pelos professores entrevistados participantes da pesquisa e o número de vezes que foram citadas.

Tabela 2 - Maneiras utilizadas pelos professores para se manterem informados em relação à Educação Ambiental e o número de vezes que são citados, em ordem decrescente. 100

Tabela 3 - Instituições responsáveis pelos momentos formativos em Educação Ambiental feitos pelos professores entrevistados e o número de vezes que foram citadas, em ordem decrescente

Tabela 4 - Conteúdos do currículo que os professores de Ciências e Geografia relacionam a Educação Ambiental, em ordem alfabética.

Tabela 5 - Recursos materiais utilizadas pelos professores e o número de vezes que foram citadas, em ordem decrescente.

Tabela 6 - Recursos metodológicos utilizados pelos professores e o número de vezes que foram citadas, em ordem decrescente. 155

Tabela 7 - Recursos do ambiente utilizados pelos professores e o número de vezes que foram citadas, em ordem decrescente 


\section{LISTA DE ABREVIATURAS E SIGLAS}

ATP - Assistente técnico pedagógico

CAPES - Fundação Coordenação de Aperfeiçoamento de Pessoal de Nível Superior

CGEA - Coordenação Geral de Educação Ambiental

CNPq - Conselho Nacional de Desenvolvimento Científico

Com-Vida - Comissões de Meio Ambiente e Qualidade de Vida nas Escolas

CPFL - Companhia Paulista de Força e Luz

DE - Diretoria de Ensino

DEA - Diretoria de Educação Ambiental

EA - Educação Ambiental

Esalq - Escola Superior de agricultura Luiz de Queiroz

FAM - Faculdade de Americana

HTP - Horário de Trabalho Pedagógico

HTPC - Horário de Trabalho Pedagógico Coletivo

Ibama - Instituto Brasileiro de Meio Ambiente

IES - Instituição de Ensino Superior

Inep - Instituto Nacional de Estudos e Pesquisa Anísio Teixeira

MEC - Ministério da Educação

MMA - Ministério do Meio ambiente

Pnuma - Programa das Nações Unidas para o Meio Ambiente

ONG - Organização Não-Governamental

ONU - Organização das Nações Unidas

PCNs - Parâmetros Curriculares Nacionais

PNEA - Política Nacional da Educação Ambiental

PRONEA - Programa Nacional de Educação Ambiental

SEMA - Secretaria Espacial de Meio Ambiente

Semae - Serviço Municipal de Água e Esgoto de Piracicaba

Senac - Serviço Nacional de Aprendizagem Comercial

SESI - Serviço Social da Indústria 
UnB - Universidade de Brasília

Unesco - Organização das Nações Unidas para Educação, Ciência e Cultura

Unicamp - Universidade de Campinas

UNIESP - Universidade do Estado de São Paulo

Unimontes - Universidade Estadual de Montes Claros

Unimep - Universidade Metodista de Piracicaba

UNISA - Universidade de Santo Amaro

USP - Universidade de São Paulo 


\section{INTRODUÇÃO}

O cuidado assume uma dupla função de prevenção de danos futuros e regeneração de danos passados. Quando amamos, cuidamos. E quando cuidamos, amamos. O cuidado constitui a categoria ventral do novo paradigma de civilização que emerge em todo o mundo.

Leonardo Boff

Nas últimas décadas, observamos o quanto a dimensão ambiental ganha destaque e deixa de ser uma preocupação de poucos para ser uma preocupação que permeia toda a sociedade. A problemática ambiental afeta a todos, ignora fronteiras geográficas e o poder econômico, tornandose, portanto, um desafio global para todos os habitantes do planeta. A escola, como não poderia deixar de ser, mostrando-se sensível aos novos desafios ambientais e, seguindo recomendações da Política Nacional de Meio Ambiente (Lei 6.938/81) e as diretrizes dos Parâmetros Curriculares Nacionais (PCNs), acaba incorporando as questões ambientais em sua grade de ensino. De fato, atualmente a Educação Ambiental (EA) é uma realidade na educação escolar. O censo escolar realizado em 2004 aponta que para 152 mil escolas, 94\% do total de escolas de todo o Brasil, a EA já faz parte das suas atividades educativas (BRASIL, 2007b).

É dentro dessa perspectiva que desenvolvemos uma pesquisa que pretendeu compreender o modo como vem sendo trabalhada a EA nas escolas da cidade de Piracicaba/SP, investigando suas práticas metodológicas, os projetos realizados e as concepções de EA dos professores. Interessa-nos saber: de que maneira a questão ambiental vem sendo trabalhada nas escolas? Como seus atores a incorporam? A possibilidade de estudar as condições da EA no ensino formal escolar é pertinente na medida em que há uma necessidade de se visualizar o modo com vem sendo desenvolvidas as práticas voltadas para a questão ambiental, verificando-se as possíveis falhas, dificuldades e necessidades dos professores e das escolas. A educação formal possui um grande potencial de transformação social e o ensino fundamental, "por ser o único nível de ensino acessível para grande maioria do povo brasileiro" (AZANHA, 1992, p. 44) pode ser uma ferramenta preciosa para formação de cidadãos. Acompanharam as indagações da pesquisa outras questões, como: de que maneira assegurar que as questões ambientais não fiquem restritas somente aos aspectos físicos e 
biológicos, mas que abordem conjuntamente os aspectos culturais, sociais, políticos e econômicos? As disciplinas do ensino formal são suficientes para disseminar entre os jovens uma consciência crítica, permitindo a formação de indivíduos autônomos, críticos e solidários como propõem as correntes de EA mais progressistas? Como organizar o currículo escolar de forma a garantir uma abordagem desse tema de modo interdisciplinar? Como enfrentar o autoritarismo tão comum na educação tradicional e ainda vigente nas escolas, para que se tenha uma educação participativa e democrática? Como inserir a temática ambiental no currículo escolar de maneira que essa possa contribuir para uma educação básica de qualidade? Essas são algumas das questões que permeiam o campo da EA e que, de maneira geral, estiveram presentes. O estudo diagnóstico da EA nas disciplinas do ensino fundamental tem o objetivo de contribuir para a reflexão da EA no ensino formal, somando-se ao conhecimento já acumulado sobre o tema e, portanto, norteando o trabalho de educadores, pesquisadores e profissionais preocupados com essas questões.

Tendo em vista essas indagações, o presente trabalho teve o objetivo de realizar um estudo diagnóstico da inserção da EA nas disciplinas do ensino fundamental ( $5^{\mathrm{a}}$ a $8^{\mathrm{a}}$ séries) em escolas estaduais e particulares do município de Piracicaba; sendo seus objetivos específicos os seguintes: i) caracterizar o tipo de trabalho que vem sendo desenvolvido por professores que dizem trabalhar a EA nas situações de ensino-aprendizagem por eles desenvolvidas na escola; ii) caracterizar o perfil desses professores em relação à sua formação e motivações para iniciar o trabalho com a questão ambiental e as maneiras pelas quais a discussão da problemática ambiental tem chegado aos docentes; iii) identificar as concepções de EA dos professores e as abordagens adotadas por eles em suas ações de ensino; iv) levantar as maneiras como os professores de diferentes disciplinas do ensino fundamental têm incorporado a EA ao currículo escolar.

As reflexões presentes neste trabalho organizam-se da seguinte forma. Nas Primeiras considerações, ainda no capítulo 1, a relação educação e sociedade é analisada e refletida para dar suporte às reflexões que envolvem a EA, a escola e a sociedade. No capítulo 2, Revisão Bibliográfica, fazemos inicialmente um breve levantamento histórico da EA e posteriormente a elaboração do quadro teórico, o qual é feito a partir do diálogo com os principais autores com quem nos aproximamos ao longo do desenvolvimento da pesquisa e que subsidia a análise e discussão dos resultados levantados na pesquisa de campo. No capítulo 3, Referencial Metodológico, expomos o contexto em que a pesquisa foi realizada, com as opções teórico-métodológicas que sustentam a 
coleta e análise dos resultados. No capítulo 4, Resultados e Discussão, reunimos os resultados obtidos pela pesquisa e sua discussão. Nesse capítulo trazemos os depoimentos dos entrevistados, as nossas interpretações e fazemos uma ponte com o contexto teórico presente no capítulo 2 , desvelando, enfim, o dia-a-dia escolar. Subdividimo-lo em três partes, a saber, Os professores que trabalham com Educação Ambiental, Concepções de Educação Ambiental dos professores entrevistados: tendências reveladas e A incorporação da Educação Ambiental na escola de ensino fundamental. E, finalmente, no capítulo 5, Considerações Finais, fazemos uma síntese dos principais pontos levantados no capítulo anterior, trazendo algumas reflexões e contribuições dessa pesquisa ao campo da EA. É importante ressaltar que esse capítulo não tem a intenção de ser conclusivo, mas sim de trazer considerações que julgamos importantes para futuros estudos direcionados a EA, como sua consolidação enquanto campo de conhecimento.

\subsection{Primeiras considerações}

Contextualizamos a presente pesquisa dentro de um cenário de crise, que teve o seu início entre as décadas de sessenta e setenta do século passado, momento em que os problemas ambientais começaram a despertar a consciência de parte da sociedade e questionamentos acerca da sobrevivência do planeta começam a ser feitos. Não que anteriormente a essa época não existissem impactos humanos sobre a natureza, uma vez que a "essência do ser humano é a transformação da natureza mediante ao trabalho" (FOLADORI, 2001, p. 107). O diferencial deste momento histórico é justamente a grandeza planetária que alcançam os problemas ambientais e a certeza de que pela primeira vez na história a espécie humana encontra-se seriamente ameaçada. Torna-se assim uma questão de sobrevivência e tem-se o princípio do despertar para um processo de busca de soluções para modos de vida alternativos - social e ambientalmente sustentáveis. Vislumbramos a emergência de uma crise ambiental e as primeiras manifestações e articulações em torno de tal crise.

$\mathrm{Na}$ década de setenta, os discursos ecológicos começam a ganhar corpo e os problemas ambientais entram nas pautas de discussões nacionais e internacionais. A partir desse período, o movimento ambientalista começa a exercer ações em âmbitos governamentais e nãogovernamentais, promover grandes conferências e encontros nacionais e internacionais e difundir cada vez mais a idéia da necessidade de uma conscientização ambiental. E se no início as discussões 
em torno das problemáticas ambientais se restringiam a alguns grupos articulados socialmente fossem eles intitulados de ambientalistas, governamentais ou representantes do status quo podemos notar o quanto nas últimas décadas essa discussão foi se disseminando. A questão ambiental passou a ocupar as manchetes de jornais e revistas, a fazer parte dos argumentos e valores de venda de diversos produtos (marketing verde), a ganhar destaque nas falas dos partidos políticos igualando-se em importância a temas como segurança, educação e saúde - e fazendo-se presente nas rodas de conversas. A despeito do espaço abrangente que a questão ambiental ocupa atualmente, podemos notar, também, o caráter superficial e genérico com que o debate muitas vezes ocorre, um preço alto a ser pago pelo movimento ambientalista e por todos aqueles que se interessam em encontrar soluções viáveis para a crise ambiental. Dessa maneira, o campo ambiental configura-se como sendo marcado por conflitos, contradições e desafios e, se há um consenso em relação à existência de uma crise ambiental, o mesmo não pode ser dito das dimensões que essa crise toma e, consequentemente, das soluções que deveriam ser tomadas para superá-la (GUIMARÃES, 2003).

Mas, afinal, quais são as faces dessa crise? Os aspectos mais óbvios já são estão amplamente assimilados por todos, como os físicos e biológicos. Entretanto, há uma crescente corrente que reivindica a inclusão de outros elementos para o debate, ampliando assim não só a abrangência dessa crise como também a sua gravidade. Assim, enquanto alguns grupos concentram a discussão nas dimensões biológicas e físicas e recorrem às soluções predominantemente de caráter técnico, outros não acreditam que poderemos entender a complexidade das questões ambientais se não a analisarmos também sob a ótica das dimensões sociais, políticas, econômicas, éticas e culturais. Guillermo Foladori (2001) é um dos autores que se mostra enfático ao colocar as soluções para as questões ambientais como primeiramente de caráter social e não técnicos. Para o autor, ao insistirmos exclusivamente nos limites físicos da natureza como causa principal da crise, “desvia-se a atenção do problema central, já que a crise ambiental, ainda que possa ser visível ou explicite um desajuste entre o ser humano e a natureza, é essencialmente uma crise das relações sociais entre seres humanos" (p. 137). É nesse sentido que acreditamos que qualquer reducionismo é incapaz de aprofundar-se na questão por centrar-se em soluções técnicas para um problema que é, primeiramente, de cunho social. Carlos Gonçalves (2004) é outro autor que defende a ampliação da discussão em torno da problemática ambiental, primeiramente, para incorporar a dimensão no âmbito político, alertando que as soluções científicas, ditas neutras, devem ser vistas com restrições: 
Ora, a ciência e a técnica são condições necessárias mas não suficientes para garantir um uso racional dos recursos naturais. Até porque o conhecimento científico se desenvolve numa relação sujeito-objeto, enquanto a prática social se dá numa relação entre sujeitos, onde o agir racional está condicionado por outras variáveis, sobretudo psíquicas, sociais e culturais. A ciência tem de reconhecer os limites de sua competência (...) (GONÇALVES, 2004, p. 57).

Para Carlos Loureiro (2004), um dos efeitos de se restringir o debate ambiental a abordagens ideológicas e simplistas é o de se dividir igualmente as responsabilidades da crise ambiental, "como se os problemas existentes decorressem da ação humana genérica" (p. 66). É daí que a crise ambiental não só nos obriga a rever a relação que temos com a natureza como também rever as relações que mantemos entre nós.

Redirecionamos assim o centro das discussões a um nível social e político, não mais unicamente ecológico. O cenário das discussões ecológicas passa a ter um caráter de movimento social e a crise ambiental amplia-se para uma "crise civilizatória, crise dos referenciais epistemológicos, filosóficos e políticos que vêm sustentando a modernidade” (TOZONI-REIS, 2002, p. 86). É nesse sentido que para Mauro Grün (1996) o cenário contemporâneo é descrito como sendo de crise generalizada, "crise de valores, crise das ideologias, crise da (ou de) ética, crise dos paradigmas, crise da modernidade, crise da cultura ocidental" (p. 60). Esse autor orienta todas essas crises para uma supercategoria que ele acredita ser a da crise ecológica, portanto, o "ambientalismo parece surgir como um grande guarda-chuva sob o qual todas as 'outras crises' podem encontrar guarida" (p. 60). De certo estamos tratando de uma crise do modo de civilização vigente, o que é particularmente verdadeiro no que tange às sociedades ocidentais, pois “(...) esta crise apresenta-se a nós como um limite no real, que ressignifica e reorienta o curso da história: limite do crescimento econômico e populacional; limite da pobreza e da desigualdade social” (LEFF, 2002, p. 191). A crise ambiental, portanto, se apresenta como resultado direto do nosso modelo de desenvolvimento: que se dá de modo altamente predador. É sobre esse atual modelo socioeconômico que devemos interferir para reverter os impactos causados ao meio ambiente. Assim, é o padrão de civilização que estamos visando transformar, e não simplesmente a busca de soluções temporárias que tendem a ajustar o modelo social vigente às atuais condições que a crise ambiental impõe. Daí que tal crise é socioambiental, pois é uma crise multidimensional, abrigando os aspectos sociais, culturais, econômicos, políticos e ecológicos.

É nesse cenário de crise socioambiental que se começa a repensar a relação entre a educação, a sociedade e o meio ambiente. Assim, uma nova abordagem para a educação é pensada, e 
a EA emerge como uma resposta, na área educacional, aos desafios trazidos pela crise ambiental (LIMA, 2004; MEDINA, 2001; TOZONI-REIS, 2002). Para Grün (1996), o simples fato de a educação moderna não contemplar o ambiente em sua totalidade e a exigência de se ter uma EA já é um sintoma de que vivemos em um momento de crise. $\mathrm{O}$ autor acredita que a EA tem como função mediar os valores existentes na relação entre os humanos e a natureza, mas, mais que inventar novos valores, a EA deveria resgatar valores esquecidos ou sufocados pela sociedade moderna, "valores estes que muitas vezes não estão no nível mais imediato da consciência, mas se encontram profundamente reprimidos ou recalcados através de um longo processo histórico" (GRÜN, 1996, p. 22).

O campo da EA nasce, pois, com a missão desafiadora de trabalhar conjuntamente com dois grandes desafios: a questão ambiental e a questão da educação (CARVALHO, 1995, 2006; TRISTÃO, 2005). Assim, ao reconhecer como legítimos os questionamentos ambientais, alguns educadores os incluem nas suas práticas educativas e passam a ser reconhecidos como educadores ambientais (CARVALHO, 2002b). A EA constitui-se desta maneira como campo de conhecimento que tem como desafio buscar respostas teóricas e práticas postas pela crise socioambiental. De certo que a EA caracteriza-se em ainda como um campo em construção (CARVALHO, 2002a; CRESPO, 1998; TOZONI-REIS, 2002, 2004; entre outros), que procura, na convergência dos campos ambiental e educacional, incorporar e contextualizar idéias herdadas dessas áreas, porém, adiciona um elemento que the confere sua especificidade: repensar as relações estabelecidas entre os indivíduos e a relação desses (sociedade) com a natureza.

É de se esperar que na aproximação entre os campos ambiental e educacional ocorram diversos e distintos encontros entre as múltiplas tendências pedagógicas e do ambientalismo (LOUREIRO, 2004b) o que imprime ao campo da EA diferentes olhares e fazeres, abrindo para sua práxis um leque de possibilidades. É desta maneira que o reducionismo existente nos debates em torno da problemática ambiental, que tratam a crise ambiental somente a partir dos seus limites externos, respinga nas propostas de EA e esta, de uma maneira geral, acaba sendo direcionada para alterar os maus hábitos e comportamentos dos indivíduos em relação à natureza. Assim, a questão ambiental acaba sendo tratada "ora como um problema estritamente ecológico, ora como um problema técnico, ora como um problema comportamental dos indivíduos", equívocos que ocorrem ao se desconsiderar a "multidimensionalidade necessária e inerente às relações entre sociedade e o ambiente" (LIMA, 2005, p. 12). De certo que há uma dificuldade em se trabalhar com propostas de 
EA que dêem conta dessa complexidade. Acrescenta-se a isso o fato de a EA ser um campo de conhecimento recente e em construção, onde diversas áreas do conhecimento transitam livremente e lhe dão sustentação teórica e prática. Configura-se, assim, como um campo "insuficientemente explorado em sua complexidade, diversidade, em sua(s) identidade(s) e alcance social" (LIMA, 2005, p. 11).

Vemos que já nas primeiras conferências internacionais e outros eventos sobre o meio ambiente tem-se o início da articulação de práticas educativas voltadas para o tema, momento em que a EA vai ganhando destaque como uma estratégia fundamental para a superação da crise ambiental. Em duas pesquisas realizadas por Crespo e Leitão (apud GUIMARÃES, 2003) - “O que o brasileiro pensa de ecologia" (1993) e "O que o brasileiro pensa do meio ambiente, do desenvolvimento e da sustentabilidade" (1997) - os autores mostram que a educação é a saída defendida pela maioria dos entrevistados. Na pesquisa realizada em 1997, os autores concluíram que para 95\% dos brasileiros a EA deveria ser obrigatória nas escolas, demonstrando que há uma forte aposta na educação para encontrar-se os caminhos que podem nos levar às mudanças necessárias. Há uma aposta cega na educação e, particularmente, na EA, como se esta, encoberta por um manto idealizador, pudesse cumprir a missão salvadora ou solucionadora dos graves problemas ambientais, supervalorizando, portanto, essa prática educativa como sendo capaz, sozinha, de reverter a crise ambiental (BURNHAN, 1993; CARVALHO, 1991, 2006; LIMA, 1999; LOUREIRO, 2003; MEYER, 1991; REIGOTA, 2001; entre outros). Essa expectativa em relação à EA impede que suas reais contribuições para a questão ambiental sejam vislumbradas. Porém, ao contrário disso, é na compreensão dos limites e possibilidades do processo educativo, na superação de tal crise, que iremos legitimar a EA enquanto prática educativa. De certo que os limites e potencialidades da educação sempre foram fonte de discussão.

A origem da educação coincide com a origem da existência humana (SAVIANI, 1988, 2000), de maneira que "não é possível fazer uma reflexão sobre o que é a educação sem refletir sobre o próprio homem" (FREIRE, 1979, p. 27). Traçando uma linha histórica, resumidamente, podemos entender como a escola vai ganhando espaço na sociedade, a tal ponto que passe a ser a forma dominante de educação. Assim, quando se fala em educação, automaticamente nos referimos à educação escolar:

(...) o desenvolvimento de processos educativos inicialmente coincidentes com o próprio ato de viver os quais foram se diferenciando progressivamente até atingir 
um caráter institucionalizado cuja forma mais conspícua se revela no surgimento da escola. Esta aparece inicialmente como manifestação secundária e derivada dos processos educativos mais gerias mas vai se transformando lentamente ao longo da História até erigir-se na forma principal e dominante de educação. Esta passagem da escola à forma dominante de educação coincide com a etapa histórica em que as relações sociais passaram a prevalecer sobre as naturais estabelecendo-se o primado de mundo da cultura (o mundo produzido pelo homem ) sobre o mundo da natureza (SAVIANI, 2000, p. 12).

Porém, ao mesmo tempo em que vemos uma hipertrofia do papel social da escola, também notamos o quanto ela é desvalorizada em nossa sociedade, contradição explicada por Saviani (2000) a partir das contradições inerentes à sociedade moderna. O autor acredita que esse paradoxo é próprio da sociedade de classes, "com interesses opostos e que a instrução generalizada da população contraria os interesses de estratificação de classes" (p. 114); de modo que a depreciação da educação escolar tem como objetivo "reduzir o seu impacto em relação às exigências de transformação da própria sociedade" (p. 114). Assim, ao mesmo tempo em que a escola se estrutura como centro por onde devem passar as transformações sociais, ela é abandonada e esvaziada de qualquer possibilidade de ação transformadora (LIBÂNEO, 1999).

É na esteira dessas discussões sobre o papel da escola que começam a surgir teorias educacionais que tentam explicar a relação da função social da escola e a divisão e marginalização de grupos sociais. Essas teorias podem ser divididas em dois pólos opostos. De um lado, estão às teorias não-críticas, que entendem a educação como um instrumento de equalização social e, portanto, tendo a escola a função de superar as divisões de classes sociais e construir uma sociedade igualitária. Do outro lado, temos as teorias críticas entre as quais, primeiramente, destacam-se as teorias crítico-reprodutivas, que percebem a educação como um instrumento de discriminação social, sendo a escola um instrumento social que reforça e legitima a marginalização, garantindo a dominação do status quo (SAVIANI, 1986; FREITAG, 1980)ํ․ Assim, a escola oscila entre a ingenuidade daqueles que supervalorizam seu poder de transformação e a descrença daqueles que, ao ver a escola apenas como uma reprodutora da ordem social, negam qualquer possibilidade de mudanças através da educação. Será que o papel da educação escolar limita-se somente a reforçar a estrutura social existente, não passando de uma força reprodutora das relações e desigualdades

\footnotetext{
${ }^{1}$ Para o autor (1986) as teorias não-críticas englobam a Pedagogia Tradicional, a Pedagogia Nova e a Pedagogia Tecnicista. As teorias crítico-reprodutivistas que tiveram maior nível de elaboração foram: Teorias do Sistema de Ensino enquanto Violência Simbólica, Teoria da Escola enquanto Aparelho Ideológico de Estado (AIE) e Teoria da Escola Dualista. Essas, porém, não contém uma proposta pedagógica, empenham-se em trazer uma explicação da educação escolar e suas críticas.
} 
sociais? Podemos lhe negar qualquer função social que venha contribuir nas transformações da sociedade vigente?

Ora, a escola está inserida numa sociedade dividida em classes com interesses opostos e é de se esperar que ela não fique imune a esses conflitos. Do mesmo modo que a educação é influenciada e determinada pela sociedade, ela também tem poder para interferir na sociedade, num movimento de ação recíproca (SAVIANI, 2000; LIBÂNEO, 1999):

Se é verdade que a transformação da sociedade não se dará exclusivamente pela ação da escola, é verdade também que a luta pedagógica é uma parte das lutas políticas. A escola mantém uma relação dinâmica com a realidade social, possibilita a luta por melhores condições de vida (...), ou seja, ela é uma ameaça à ordem estabelecida. O menosprezo da educação escolar coloca-a ao abandono, deixa-a nas mãos do sistema político vigente (LIBÂNEO, 1999, p. 49).

Entender a escola como uma instituição desvinculada das outras instituições sociais, como se pudesse ser construída de maneira autônoma da sociedade, impossibilita entender o movimento contraditório que, ao mesmo tempo em que universaliza a educação escolar, a neutraliza perante a sociedade. É nesse sentido que, a partir da imobilidade das críticas feitas ao papel social da escola, se inicia a articulação de teorias que procuram, de maneira igualmente crítica, enxergar a escola como uma instituição, entre outras instituições sociais, que é capaz de contribuir com a transformação da sociedade. Tem-se, assim, a constituição da Pedagogia Progressista, de Georges Snyders; da Pedagogia Libertadora, de Paulo Freire; da Pedagogia Libertária, de Freinet, Tratemberg e outros; e da Pedagogia Histórico-crítica, de Saviani e outros.

O equívoco, portanto, é exatamente supervalorizar o poder da educação:

Os valores não podem ser construídos pedagogicamente e difundidos didaticamente em programas educativos. Os valores se constroem nas práticas e nos saberes reciprocamente implicados. E mais do que isso, são contextualizados numa rede singular de poder que lhes confere um lugar de significação. Assim, produzir valores é se engajar nas práticas que disputam, muito concretamente, no dia a dia da vida social, o acesso ao imaginário social, e à produção dos saberes. A educação não está fora desse movimento. É também uma prática social, engajada num movimento histórico e numa formação de poder. E é desse lugar que engendra uma produção particular de saber. No entanto, esse saber não é mais legítimo que outros, uma vez que estamos falando de um saber formal, organizado em conteúdos. Nesse sentido, todas as práticas geram saber e, portanto, são educativas (CARVALHO, 1991, p. 48). 
A escola tem um papel político importante na sociedade moderna, sendo um espaço de formação de cidadãos (RODRIGUES, 2001), portanto, articula-se com outras práticas sociais comprometidas com um projeto de mudança da sociedade. $\mathrm{O}$ ato de educar é, acima de tudo, um ato político e o educador, ao traçar os objetivos da educação, "revela sua atitude em face da realidade e adota uma posição em relação a ela; orienta-se no sentido de contribuir para a reprodução, ou para a transformação da ordem social vigente" (GONÇALVES, 1994, p. 473). Dessa maneira, a construção de uma prática educativa comprometida com uma educação emancipatória nasce da compreensão das contradições históricas que permeiam a função social da escola (SAVINI, 2000), pois, se sozinha a escola não é capaz de mudar a sociedade, tão pouco podemos negar-lhe sua contribuição social. De fato, as "possibilidades da educação se expressam primeiramente na consciência de seus limites" (CURY, 1985, p.22 apud CARVALHO, 2006, p. 21).

Reconhecemos na EA sua dimensão educativa e defendemos a construção de uma escola que esteja em sintonia com os desafios contemporâneos. Acreditamos que o trabalho da incorporação da EA ao currículo escolar, com todos os seus pressupostos contemplados, é também um trabalho em defesa da qualidade da educação escolar básica (MEDINA, 1999, 2001), uma vez que sua inserção exigirá da escola mudanças que poderão refletir na melhoria da educação em geral. Assim, acreditamos que o campo da EA:

(...) guarda a potencialidade de promover a reflexão e a problematização das relações entre sociedade e o meio ambiente e de influir sobre a sensibilidade e a consciência dos indivíduos e coletividade sobre a natureza problemática dessas relações e sobre as mudanças necessárias ao seu redirecionamento. Consiste, portanto, em um instrumento, entre outros, portador da capacidade de promover mudanças que forneçam respostas aos desafios ambientais contemporâneos (LIMA, 2005, p. 12).

Entendemos, enfim, que a introdução da EA ao currículo escolar torna-se uma oportunidade ímpar para que a educação possa recuperar seu papel social de formar cidadãos, ao aproximar a escola dos desafios trazidos pela problemática ambiental e, assim, situar educandos e educadores enquanto sujeitos históricos (FREIRE, 2005). A educação escolar passa a:

(...) vincular a pedagogia do ambiente a uma pedagogia da complexidade; quer dizer, induzir e fomentar as capacidades e habilidades mentais para ver o mundo como sistemas complexos, para compreender a causalidade múltipla, a indeterminação e a interdependência entre diferentes processos; para articular-se subjetivamente na produção de conhecimentos e nos sentidos do saber. Isto 
implica em revalorizar o pensamento crítico, reflexivo e propositivo frente às condutas automatizadas que são geradas pelo pragmatismo e pelo utilitarismo da sociedade atual (LEFF, 2001, p. 126).

Acreditamos que a incorporação da EA à educação escolar guarda em si a possibilidade de se compreender a crise ambiental em todas nas dimensões social, histórica, política e cultural, ao direcionar o currículo escolar para a compreensão e interpretação crítica da realidade local-global. Assim, a EA dá fôlego para aqueles que desejam traçar caminhos concretos para as transformações no modelo social dominante ao devolver a esperança de que tais caminhos existem e são possíveis, podendo contribuir para que novas relações sejam construídas entre o indivíduo, a sociedade e a natureza. De certo que as transformações sociais que tanto almejamos nos parecem muitas vezes existirem apenas num nível utópico. Mas é também de esperanças que o educador e educando alimentam-se, pois “quando uma educação já não é utópica (...) é porque o futuro perde sua real significação ou porque se instala o medo de viver o risco do futuro como superação criadora do presente que envelhece" (FREIRE, 2002, p. 71). Sabemos o quanto é desafiadora e complexa a construção de uma educação comprometida com as mudanças sociais. Mas, qualquer que seja o caminho escolhido para tais mudanças, essas certamente passarão pela educação. É nesse sentido que para Paulo Freire qualquer processo educativo comprometido com a transformação social deve ter como um dos seus pressupostos a convicção de que a mudança, embora difícil, é possível, uma vez que a realidade social é dinâmica e composta por seres históricos:

O mundo não é. O mundo está sendo. Como subjetividade curiosa, inteligente, interferidora na objetividade com que dialeticamente me relaciono, meu papel no mundo não é só o de quem constata o que ocorre mas também o de quem intervém como sujeito de ocorrências. Não sou apenas objeto da História mas seu sujeito igualmente. No mundo da História, da cultura, da política, constato não para me adaptar mas para mudar. (...) Constatando, nos tornamos capazes de intervir na realidade, tarefa incomparavelmente mais complexa e geradora de novos saberes do que simplesmente a de nos adaptar a ela. (...) Ninguém pode estar no mundo, com o mundo e com os outros de forma neutra (FREIRE, 1996, p. 77). 


\section{REVISÃO BIBLIOGRÁFICA}

(...) a ecologia faz renascer a relação, esquecida e escondida, da sociedade com a utopia - utopia compreendida como desejo de mudança e horizonte de nossa atividade, sem que se prejulgue a respeito da possibilidade de materialização efetiva dessa mudança.

C. Castoriadis

É comum em trabalhos relacionados à EA nos depararmos com um levantamento exaustivo dos encontros e conferências internacionais e das publicações que são apontados como marcos históricos do campo ambiental, como A primavera silenciosa (1962), de Rachel Carlon, que marca o ponto de partida para o desencadeamento de uma série de encontros, eventos e publicações em torno da temática ambiental (DIAS, 1999). Publicações e eventos são muitas vezes apresentados num arranjo cronológico que levou Isabel Carvalho (2002a) a caracterizar o surgimento de um mito de origem, por interligar fatos e suas seqüências, "sugerindo a idéia de uma relação casual entre desastres ambientais e avanços da consciência ecológica" (p. 154). Para a autora o que existe é uma relação circular de auto-reflexão que contribuiu para legitimação do campo ambiental, onde "se os desastres criam a consciência ambiental, é a consciência ambiental que cria a leitura desses fatos como desastres ambientais" (p. 154-155). É nesse sentido que para Loureiro (2004a) existe um engano na simplificação do desenvolvimento da EA, como se esta tivesse surgido de um processo histórico linear, ou seja, uma modalidade educacional focada inicialmente na conservação da natureza e que, posteriormente, transformou-se em uma educação que pensa o ambiente de maneira integrada. Porém, ao contrário, do seu surgimento até os dias de hoje, a EA passou por avanços nos seus princípios que são resultado de um "conjunto complexo de relações e interações no tempo e não apenas por um acúmulo de conhecimento" tornando-se "expressão concreta e especificas de diferentes abordagens ambientalistas e pedagógicas que se configuram (...) de modo plural e tensionado" (LOUREIRO, 2004a, p. 74).

Estamos cientes de que um levantamento histórico sem o devido olhar crítico pouco poderá contribuir para o entendimento do contexto cultural e político em que a EA foi forjada. Mas, tal como aponta Carvalho (2002a) trata-se de um campo novo, um "fenômeno social recente" (p. 76) no 
Brasil e no mundo ${ }^{2}$. A aproximação histórica traz dificuldades para aqueles que pretendem compreendê-la, mas tal compreensão faz-se necessária uma vez que esse um é campo complexo e cujas indagações emergentes tornaram-se fundamentais para que os cidadãos possam tomar suas decisões de maneira consciente perante os graves e urgentes problemas ambientais. É nessa linha que Vivien Diesel (1994) acredita ser importante entender o contexto social, político e econômico das propostas de EA, porque, para a autora, sem esse esforço podemos ser levados a "sustentar estratégias educativas que tendem a perder legitimidade e poder de mobilização" (p. 35). Lima (1999) ressalva a importância de se questionar todos os documentos oficiais produzidos nas realizações de encontros e conferências que são aceitos muitas vezes como uma referência neutra e legítima. É nesse sentido que Loureiro (2004a) acredita que muitos conceitos-chave discutidos durantes as grandes conferências, como participação e interdisciplinaridade, foram indevidamente apropriados e, por isso, pouco puderam contribuir para as mudanças tão almejadas:

Ficou-se no patamar das idéias, sem que a base epistemológica e filosófica do corpo teórico utilizado e a dinâmica societária, política e econômica do que é questionado tivessem condições de ser efetivamente confrontadas, negadas e dialeticamente superadas (LOUREIRO, 2004, p. 75).

Ao levantarmos os principais acontecimentos desde o seu surgimento estamos querendo localizar a EA historicamente, atribuindo-lhe um significado ao "ambiental" que, ao ser somado à dimensão educacional, possa ir além de um simples adjetivo. Assim, estrutura-se uma EA que esteja comprometida com um projeto político-pedagógico afinado com as mudanças profundas em nossa sociedade, na medida em que seja capaz de formar novos valores éticos e reorientar a relação entre os humanos e destes com a natureza.

\footnotetext{
${ }^{2}$ A autora faz três cortes geracionais, que abrangem dos anos 70 até os anos 90, para demarcar o campo ambiental. Os fundadores - a primeira geração, aqueles com 55 anos e que "participaram do contexto fundacional no qual a questão ambiental como debate e ação organizada emerge na esfera pública como tema de interesse e relevância para a sociedade. A segunda geração, denominada de primeira geração pós-fundadores, são os indivíduos entre 35 e 55 anos e que tem na geração dos fundadores sua inspiração e modelo para ação. São indivíduos com a graduação finalizada entre o final dos anos 60 e início dos anos 80 e atuam no campo há mais de dez anos. O último corte feito foi denominado de segunda ou nova geração e seria composta por indivíduos com até 35 anos, os quais atuam no campo há pouco tempo e cursaram a graduação entre os anos 80 e 90.
} 


\subsection{0 "ecológico" em disputa e o percurso da Educação Ambiental}

O fim da década de sessenta pode ser considerado o marco mundial do início das manifestações e questionamentos ecológicos (CARVALHO, 1991, 1997, 2002a, b; DIAS, 1991, 1999; DIESEL, 1994; FOLADORI, 2001; GUIMARÃES, 2003; JACOBI, 2005; MEDINA, 1997 ; TOZONI-REIS, 2002; entre outros). Para o presente estudo esse recorte histórico faz-se necessário, mas estamos cientes de que a percepção da problemática ambiental e o surgimento de uma consciência ecológica são herdeiros de uma longa tradição de sensibilização que percorreram séculos de história humana, passando pela:

(...) compreensão iluminista de uma natureza controlada pela razão, pela visão pastoral idílica do naturalismo inglês do século XVII, pelas novas sensibilidades burguesas do século XVIII, pelo romantismo europeu dos séculos XVIII e XIX e pelo imaginário edênico sobre a América (CARVALHO, 2002a, p. 40).

É no contexto de questionamento do modelo de desenvolvimento ocidental e de uma seqüência de desastres ambientais, amplamente divulgados por publicações de impacto internacionais, que emerge o movimento ambientalista. Fruto do movimento contracultural e emancipatório dos anos sessenta que denunciava as mazelas das sociedades industrializadas (CARVALHO, 1997), extrapola o movimento conservacionista cujo interesse estava centrado na proteção exclusiva dos recursos naturais:

O novo movimento ambiental, sem descartar essas motivações, superou-as, estendendo seu interesse a uma variedade maior de fenômenos ambientais. Alegava que a violação dos princípios ecológicos teria alcançado um ponto tal que, no melhor dos casos, ameaçava a qualidade de vida e, no pior, colocava em jogo a possibilidade de sobrevivência, a longo prazo, da própria humanidade (MEDINA, 1997, p. 258).

Diferentemente de outros movimentos sociais, o ambiental já se inicia no plano internacional por incorporar variados atores sociais que trazem para sua discussão motivações e reivindicações também diversificadas. Se os anos sessenta marcaram o início de uma ebulição de uma consciência ambiental, é nos anos setenta que vislumbramos a institucionalização da problemática ambiental pelos órgãos governamentais de vários países assim como também a articulação da sociedade civil (CARVALHO, 2002a; DIESEL, 1994). É nessa década que se iniciam 
os vários eventos nacionais e internacionais que procuram encontrar soluções para a crise ambiental que já se encontrava incorporada pela sociedade. Porém, longe de representar uma expressão conciliadora, o termo "ecológico" transforma-se em alvo de disputa por grupos com interesses adversos (CARVALHO, 1991; CRESPO, 1998; DIESEL, 1994; LIMA, 2005; LOUREIRO, 2004a) que possuem um entendimento diferenciado no que se refere à relação indivíduo-natureza e os possíveis caminhos para a superação da crise ambiental (GUIMARÃES, 2003; LOUREIRO, 2004a). Essa disputa, grosso modo, pode ser representada por duas correntes principais antagônicas que Carvalho (1991) denomina de discurso ecológico oficial e discurso ecológico alternativo. Para a autora, o primeiro é produzido pelos organismos governamentais nacionais e/ou internacionais que ao institucionalizar um discurso sobre o meio ambiente o apresenta como se houvesse um consenso mundial sobre o assunto, isto é, "tende a recuperar as principais indagações do discurso ecológico alternativo, desterritorializando-as para em seguida reterritorizá-las dentro de uma ótica de sobrevivência do sistema" (p. 35). Crespo (1998) vê na corrente hegemônica, que chama de ambientalismo pragmático ou ecologia de resultados, uma preocupação de ao menos desacelerar o processo de aniquilamento dos recursos, procurando encontrar dentro dos próprios sistemas sócioeconômicos vigentes soluções que possam manter o desenvolvimento econômico e a sustentabilidade dos recursos naturais. Já a corrente que questiona esse modelo civilizatório, que a autora chama de ambientalismo ideológico, ecologismo profundo ou ecologismo ético, coloca em xeque a relação homem-natureza historicamente construída. Diesel (1994) também observa uma polarização das linhas interpretativas ecológicas nos anos 70: de um lado, o grupo preocupado com o ritmo de desenvolvimento e, de outro, os que enfatizavam a necessidade de uma nova ética e novos valores por considerarem a crise ambiental uma crise no interior da sociedade. A autora aponta como legitimação científica das teses do primeiro grupo - detentor do discurso ecológico oficial - a publicação, em 1972, pelo Clube de Roma, do estudo "Limites do Crescimento". É dentro desse campo ambiental, com disputas acirradas e antagônicas, que as propostas de uma educação voltada para o ambiente vão ganhando corpo e a EA vai sendo estruturada como prática educativa.

A publicação "Limites do Crescimento" previa catastroficamente que dentro de poucas décadas o planeta estaria com seus recursos esgotados e recomenda, como uma medida de restabelecimento do equilíbrio econômico e ecológico, o crescimento zero da população global e do capital industrial. É dentro deste contexto pessimista e de crise ambiental que, nesse mesmo ano, a Organização das Nações Unidas (ONU) e seus países membros iniciam a institucionalização da problemática ambiental e da EA e realiza-se a "Conferência das Nações Unidas para o Ambiente 
Humano", em Estocolmo. Essa conferência marca o início de uma série de encontros internacionais bancados principalmente pela ONU e juntos têm um papel importante na institucionalização da EA tanto a nível mundial quanto nacional ${ }^{3}$. A repercussão e documentos resultantes de cada um desses encontros fizeram ecos no Brasil o que ajudou muito que se iniciasse a divulgação do campo da EA no país.

Atualmente o formato de grandes encontros internacionais começa a ser questionado. Para Marcos Sorrentino (2000), após a "Conferência Internacional sobre Meio Ambiente e Sociedade: Educação e Conscientização Pública para Sustentabilidade”, ocorrida em Thessaloniki, na Grécia, em 1997, esse formato de conferências internacionais já se mostra esgotado. Foladori (2001) também é outro autor que questiona a eficiência dos grandes eventos:

(...) fica claro que a preocupação manifesta se dá em torno de como reduzir os níveis de poluição, de depredação e de pobreza e superpopulação, sem tocar na forma social de produção, ou seja, no capitalismo. Em que medida essas melhorias, que vão, aparentemente, contra a lógica da própria dinâmica capitalista, conseguem ser suficientemente eficazes é algo que somente dentro de algumas décadas poderemos saber (FOLADORI, 2001, p. 119).

A Conferência de Estocolmo, como ficou conhecida, foi um marco para o discurso ecológico oficial e suas orientações tiveram repercussão mundial e serviram de referência para a maioria das publicações, programas e documentos nesse período (Carvalho, 1991). O enfoque era a vulnerabilidade do planeta diante dos graves problemas ambientais e assinala-se a urgência da necessidade de o homem reordenar suas prioridades, colocando, assim, o ser humano como responsável pela manutenção do nosso planeta (SATO, 1997). Embora se recomende um programa internacional de EA, "com vistas a educar o cidadão comum para a compreensão dos mecanismos de sustentação da vida na Terra" (DIAS, 1991, p. 4), Diesel (1994) vê com restrições a proposta de EA produzida em Estocolmo:

A educação ambiental será definida apenas em um artigo (princípio 19) com o sentido de estabelecer a responsabilidade dos indivíduos na proteção e melhoramento do meio ambiente. Apresenta-se, portanto, de forma asséptica, destituída de seu conteúdo utópico mais genuíno, compatível com a orientação tecnocrática já observada em outras ações recomendadas neste evento (DIESEL, 1994, p. 40).

\footnotetext{
${ }^{3}$ A expressão Educação Ambiental foi, de fato, usada pela primeira vez na Conferência de Educação na Universidade Keele/Grã-Bretanha, onde os educadores reunidos sinalizaram a importância de se incluir a dimensão ambiental na educação escolar (MEDINA, 1997; MEYER, 1994).
} 
É durante a Conferência de Estocolmo que o Brasil tem uma performance polêmica ao declarar que a degradação ambiental é o preço a ser pago para o desenvolvimento econômico do país (DIAS, 1991). Assim, essa conferência fica marcada pelas posições opostas de conservacionistas dos países do Norte e desenvolvimentistas dos países do Sul (DIESEL, 1994).

Seguindo recomendações da Conferência de Estocolmo, a Organização das Nações Unidas para Educação, Ciência e Cultura (Unesco) e o Programa das Nações Unidas para o Meio Ambiente (Pnuma) assumem as organizações dos próximos encontros regionais e internacionais de EA. Assim, em 1975, na Iugoslávia, ocorre o Encontro de Belgrado, onde foram formulados os princípios e orientações para um programa internacional de EA. Em seguida, em 1977, a Unesco e Pnuma promovem em Geórgia, ex-URSS, a "Primeira Conferência Intergovernamental sobre Educação Ambiental". A Conferência de Tbilisi, como ficou conhecida, gerou a "Declaração sobre Educação Ambiental", documento sobre as finalidades, objetivos, princípios orientadores e estratégias para o desenvolvimento da EA e elegia o treinamento de pessoal, o desenvolvimento de materiais educativos, a pesquisa de novos métodos, o processamento de dados e a disseminação de informações como a mais urgente dentro das estratégias de desenvolvimento da EA (DIAS, 1999).

Para Diesel (1994), o discurso de EA em Tbilisi aparece mais articulado. Esta autora ao analisar as recomendações da Unesco vê "a transição de uma concepção de educação ambiental centrada na modificação de valores e comportamentos individuais, para uma preocupação com a transformação como projeto coletivo" (p. 45). Loureiro (2004a) também observa avanços nas propostas de Tbilisi, que une a EA ao meio educativo, articulando as dimensões ambiental e social. Também ressalta o cuidado que se tem em não creditar somente à EA a responsabilidade de reverter o quadro da crise ambiental. Embora este autor reconheça Tbilisi como uma referência para o campo da EA, sinaliza para a existência de aspectos contraditórios nas suas recomendações:

(...) os questionamentos feitos à educação tradicional se baseiam numa defesa da pedagogia tecnicista (...). Defende uma "Nova Ordem Mundial", mas não há referências a como esta seria diferenciada do modo como veio se consolidar (...). Coloca que a economia de mercado possui limites e impõe limites à sustentabilidade, mas não indica alternativas consistentes, a não ser o vago discurso da solidariedade entre países e da cooperação tecnológica em busca da eqüidade social (...) sugere-se que os problemas nos países do "terceiro mundo" decorrem de formas insuficientes de desenvolvimento, não relacionando as desigualdades entre os países a processos históricos de dominação e subordinação (LOUREIRO, 2004a, p. 74). 
No ano de 1987, dez anos após a Conferência de Tbilisi, acontece em Moscou o "Congresso Internacional de Educação Ambiental e Formação Ambiental" com o objetivo de avaliar os resultados desenvolvidos durante a década e traçar uma estratégia internacional para EA (LIMA, 1999). Neste mesmo ano, é publicado "Nosso Futuro Comum", também conhecido como Relatório Brundtland, produzido pela Comissão Mundial sobre Meio Ambiente e Desenvolvimento. O conceito desenvolvimento sustentável passa então a substituir o termo ecodesenvolvimento ${ }^{4} \mathrm{e}$ reorienta toda a política de desenvolvimento e sua relação com as questões ambientais (SORRENTINO et al., 2005). Porém, embora o discurso de desenvolvimento sustentável abrace princípios de justiça social, viabilidade econômica e prudência ecológica (LIMA, 1997), estes são tratados superficialmente e é visível seu compromisso com o discurso ecológico oficial. O debate político e conteúdo emancipatório acabam diluindo-se nas esferas econômicas e tecnológicas para que seja alcançado um discurso mais conciliador (LIMA, 2003), o que produzirá grande impacto nas propostas de EA futuras. Diesel (1994) observa que em termos gerais a Conferência de Moscou não avança muito em relação às premissas de EA já elaboradas em Tbilisi, mas, na literatura, já notamos uma preocupação em definir a EA nos princípios do desenvolvimento sustentável.

É em meados dos anos oitenta que Lima (2005) observa que no Brasil se inicia a estruturação e circulação de uma literatura voltada especificamente à EA, contribuindo para reflexões críticas sobre o assunto. O autor cita como pioneiros os trabalhos de Kazue Matshushima, Marcos Sorrentino, Isabel C. de Moura Carvalho, Luiz Marcelo Carvalho, Maria Lúcia Leonardi, Marcos Reigota, Mônica Meyer e Michele Sato.

Em 1992, é realizada no Brasil a "Conferência das Nações Unidas sobre Meio Ambiente e Desenvolvimento", a Eco-92 ou Rio-92. Mônica Meyer (1994) chama atenção para o fato de que esse foi o primeiro evento ambiental de amplitude internacional sediado por um país latinoamericano, subdesenvolvido e de terceiro mundo. A "Agenda 21", documento oficial da conferência, especialmente o Capítulo 36, recontextualiza e amplia os princípios e recomendações de Tbilisi. A EA é organizada em três eixos: "reorientação do ensino para o desenvolvimento sustentável, aumento da consciência pública e promoção do treinamento" (TOZONI-REIS, 2004, p. 5). Outro documento produzido por essa conferência foi o "Tratado de Educação Ambiental para Sociedades Sustentáveis e Responsabilidade Global”, com dezesseis princípios estabelecidos. Esse documento

\footnotetext{
${ }^{4} \mathrm{O}$ conceito de ecodesenvolvimento tem como mentor Ignacy Sachs e reúne em sua proposta desenvolvimento com valorização cultural (DIESEL, 1994; LIMA, 1997).
} 
foi elaborado em evento paralelo à Rio-92, no âmbito do "Fórum Internacional das Organizações Não-Governamentais”, promovido pelas Organizações Não-Governamentais (ONGs) - conhecido como o Fórum das ONGs.

A Rio-92 foi responsável pela popularização da ecologia assim como da EA na medida em que, desde 1989, houve uma mobilização no mundo, sobretudo no Brasil, para a preparação dessa conferência (REIGOTA, 1998; CARVALHO, 1995, 2002a). Carvalho (2002a) lembra que a sociedade civil preparou-se para o evento com a organização do Fórum das ONGs, que teve a realização de oito encontros nacionais para preparar a agenda temática da Rio-92 e organizar o Encontro Internacional de ONGs e Movimentos Sociais:

(...) houve uma interiorização da discussão ecológica, um espectro amplo dos movimentos populares, que puderam ver muitas de suas lutas como lutas também ambientais. Essa ecologização dos movimentos sociais representou igualmente uma maior politização dos movimentos ecológicos, que puderam mais facilmente associar suas lutas específicas ao questionamento dos recursos naturais e a degradação das condições de vidas das populações que dependem destes recursos para sua sobrevivência. (CARVALHO, 1995, p. 61).

Assim, para a autora, a Rio-92, particularmente o Fórum das ONGs, possibilitou a coalizão dos educadores ambientais com outros setores da sociedade civil que não só o ambiental. Se de um lado essa aproximação possibilitou uma ampliação do debate das questões ambientais por variados grupos sociais, por outro lado também ocorre uma diluição e abrangência da ideologia, temáticas e reivindicações, o que colocou em risco a identidade ambiental do evento (CARVALHO, 2002a). Porém, essa abertura do debate não impediu o sucesso do Fórum das ONGs, que termina com a construção de uma "identidade política sob o signo da qualidade de vida e da crítica ao modelo de desenvolvimento vigente" (CARVALHO, 2002a, p. 150).

O último encontro internacional que abordou a questão ambiental foi realizado em 2002 em Johannesburgo, África do Sul, quando ocorreu a Cúpula Mundial sobre Desenvolvimento Sustentável, conhecida como Rio +10 . Nesse encontro foi realizado um balanço dos dez anos da Agenda 21 e reafirmou-se a insustentabilidade do modelo econômico vigente. A EA, dentro da perspectiva desse evento, é afirmada como uma estratégia para alcançar o desenvolvimento sustentável (TOZONI-REIS, 2004).

Todos esses eventos internacionais nos permitem visualizar o surgimento e as trajetórias que a EA percorreu para a estruturação de suas propostas no contexto do campo ambiental. Assim, 
se em 1950 tínhamos uma educação que se alinhava com um movimento conservacionista, na década de 1970 observamos a composição de uma educação que procura englobar a dimensão ambiental extrapolando os limites da ciência ecológica e que passa a ter uma nova abordagem. Nessa época observamos um conjunto de experiências pioneiras relativas à EA, mas ainda marcadas por um viés naturalista. Na década de oitenta, na esteira da difusão da problemática ambiental para todos os setores sociais e a proliferação das instituições ambientais, vemos a ampliação conceitual da EA que incorpora os aspectos sociais, políticos, econômicos e culturais. Na década de noventa a EA começa a ser orientada nitidamente para uma educação para a sustentabilidade (LOUREIRO, 2004a; SATO, 1997). Notamos também o quanto os espaços conquistados pela EA na sociedade e nos governos brasileiros aconteceram por meio de caminhos tortuosos, descontínuos e na maioria das vezes de forma precária, o que demonstra que a questão ambiental não tem sido contemplada como prioridade no país (LIMA, 2005; CARVALHO, 2002a; DIAS, 1991).

Já vimos o quanto o campo ambiental é um campo em constante disputa de diversos grupos sociais e, portanto, encontra-se longe de ser homogêneo. O mesmo é de se esperar das propostas relacionadas à EA. Assim, se de um lado temos as correntes que idealizam uma EA que prioriza a informação e a racionalidade técnico-científica apostando em mudanças de hábitos e atitudes para a superação da crise ambiental dentro dos limites do sistema vigente, do outro temos as correntes que acreditam em novos valores, nova sensibilidade e nova ética individual e coletiva, capazes de estabelecer uma relação entre sociedade e natureza que não seja a mesma existente dentro do modelo civilizatório esgotado atual; que estão, enfim, em busca de uma novo paradigma científico e social (RUSCHEINSKY, 2001). Se esta última corrente defende o ambiental como substantivo e alinha a EA dentro de um campo ambiental que é social e historicamente construído, contextualizando-a nos limites das lutas dos movimentos sociais e ecológicos que criticam o modo de vida dominante (CARVALHO, 2002b), a primeira corrente procura neutralizar a expressão ambiental, classificandoa como adjetivo. Na esteira dessa primeira corrente vemos a Unesco introduzindo a década (20052014) da "Educação para o Desenvolvimento Sustentável” (CARVALHO, 2002b; LIMA, 2003; MEIRA; SATO, 2005; SAUVÉ, 2005a) como já era sinalizado nas propostas de EA das últimas conferências. Lucie Sauvé (2005a) vê um equivoco dentro dessa proposta de educação:

A concepção utilitarista da educação e a representação 'recursista' do meio ambiente (...) mostram-se nitidamente reducionista com respeito a uma educação fundamental preocupada em otimizar a teia entre pessoas, o grupo social a que 
pertencem e o meio ambiente. A relação com o mundo não pode ficar limitada a uma dinâmica de 'gestão de recursos'; as atividades humanas não podem ser interpretadas unicamente dentro do quadro de referência do 'desenvolvimento', utilizando exageradamente a linguagem da sustentabilidade (SAUVÉ, 2005a, p. $320)$.

Essa nova proposta coloca em risco o potencial educacional da EA Primeiro porque o próprio conceito de desenvolvimento sustentável é ambíguo e contraditório e está sujeito a diferentes interpretações, sendo que suas propostas variam "desde um neoliberalismo econômico, até a construção de uma nova racionalidade produtiva" (LEFF, 2001, p. 23). Segundo porque ignora todo o processo histórico e conflitos sociais e políticos em que a EA vem se desenvolvendo. Assim, os que defendem uma educação para o desenvolvimento sustentável estão propondo a manutenção do status quo que há décadas vem sendo criticado pelos movimentos ecológicos como os responsáveis por gerar e manter a crise ambiental instalada em nossa sociedade. Desta maneira, mostra-se incapaz de ser uma prática social que se encontra apta a firmar um novo pacto entre sociedade e natureza.

\subsubsection{As políticas públicas nacionais de Educação Ambiental}

São nos conturbados anos de ditadura militar que o debate ambiental instaura-se no país. As primeiras iniciativas de institucionalizar uma política ambiental brasileira aconteciam mais por pressões internacionais do que como uma reivindicação dos movimentos ambientalistas, portanto, tendo suas diretrizes e estratégias definidas sem a participação popular (LOUREIRO, 2004). Somente nos anos oitenta, com a abertura política, que a EA começa a vislumbrar um espaço maior e criar uma identidade:

Essa educação voltada para o meio ambiente que se denomina ambiental e que se distingue de outras educações é, no Brasil, um fenômeno que se incrementa com o surgimento dos novos movimentos sociais e ONGs ambientalistas nos anos 1980. É principalmente no contexto de uma política afirmativa das novas temáticas culturais e atores sociais que mais e mais educadores incorporam um ideário ecológico em sua prática educativa e passam a chamar-se educadores ambientais. Desde então, podemos observar a organização, num ritmo crescente, de encontros estaduais, nacionais, e mais recentemente latino-americanos, que poderiam ser vistos como parte da construção de uma identidade social e profissional em torno das práticas educativas ambientais (CARVALHO, 1997, p. 277-278). 
É nesse contexto que, no final de 1973, como resultado da grande pressão internacional que o governo brasileiro sofreu após a Conferência de Estocolmo, é criado o primeiro organismo oficial brasileiro para gestão integrada de meio ambiente. (DIAS, 1991; LOUREIRO, 2004a; MEYER, 1994). A Secretaria Especial do Meio Ambiente (SEMA) funcionou entre os anos de 1974 e 1989 e, após esse período, une-se com outros organismos oficiais e forma o Instituto Brasileiro de Meio Ambiente (Ibama). Apesar dos seus limites institucionais, a SEMA exerceu na época um papel importante na estruturação de políticas públicas voltadas para o meio ambiente. Foi responsável pelo primeiro esforço de incorporar a temática ambiental no ensino formal ao organizar em Brasília, juntamente com a Fundação Educacional do Distrito Federal e a Fundação da Universidade de Brasília, cursos de extensão para professores de ensino de $1^{\circ}$ Grau. Entre 1977 e 1981, desenvolveu o projeto de Educação Ambiental de Ceilândia (DF) que foi pioneiro ao pensar um currículo interdisciplinar e unir a educação escolar com as demandas da sua comunidade e também fomentou a discussão ambiental nas Universidades ao promover uma série de debates e seminários. Em 1986, com o amparo do Conselho Nacional de Desenvolvimento Científico (CNPq), da Fundação Coordenação de Aperfeiçoamento de Pessoal de Nível Superior (CAPES) e Pnuma, organiza o I Curso de Especialização em Educação Ambiental, juntamente com a Universidade de Brasília (UnB), voltada para formação de profissionais de nível superior (DIAS, 1991; MEYER, 1994).

Em 1981, com a publicação da Lei 6.938, a Política Nacional de Meio Ambiente é instituída. Embora tenha sido um passo importante para a questão ambiental ao incluir a EA em todos os níveis de ensino, pouco contribuiu, pois ainda a discussão ambiental continuou presa aos limites da ciência ecológica, sem que seus componentes sociais, culturais, econômico e políticos fossem contemplados (DIAS, 1991). Em 1987, na esteira da Conferência de Moscou onde os países participantes deveriam apresentar os avanços após dez anos da realização da Conferência de Tbilisi, o Conselho Federal de Educação aprova o Parecer 226/87, em que a EA deve ser incluída nos conteúdos curriculares do ensino fundamental e médio, em caráter interdisciplinar. Um ano depois, já com uma articulação e participação de entidades ambientalistas civis, é incluído na Constituição Federal de 1988 um capítulo sobre meio ambiente e artigos afins. Os cidadãos passam então a ter direito a um ambiente sadio e ecologicamente equilibrado garantido constitucionalmente, mesmo que a princípio esse ganho não afete diretamente a vida dos brasileiros.

Durante a década de oitenta a EA ainda lutava para ter seu lugar reconhecido pelas políticas públicas voltadas para o meio ambiente e na maior parte desse período conviveu com um viés 
conservacionista $^{5}$ e teve sua implementação ocorrida de forma precária e marginalizada das prioridades dos governos do nosso país. Carvalho (2002a) ressalta que mesmo tendo uma origem forçada por pressões externas e ter sido formada de maneira dispersa e descontinua, a política ambiental conseguiu avançar muito com a contribuição dos órgãos públicos de meio ambiente. Em alguns casos, esses eram espaços de referência para militantes, ambientalistas e educadores ambientais.

$\mathrm{Na}$ década de noventa o debate ambiental ganha novo fôlego. Acontecem os primeiros encontros nacionais e inúmeros simpósios espalham-se pelo país. Década também de preparação para Rio-92 e de repercussão global da questão ambiental, que fazem dos primeiros anos dessa década um momento importante para EA no Brasil, não só na ampliação do seu conceito, na qual o Tratado de Educação Ambiental elaborado durante o Fórum Global é ainda referência, como também pela expansão do tema em vários setores da sociedade civil, extrapolando o âmbito do movimento ecológico. A conferência ocorrida no Rio de Janeiro também produziu a Rede Nacional de EA, que organizou, pós-conferência, quatro fóruns nacionais. Em 1997, depois de cinco anos da Rio-92, é realizada a I Conferência Nacional de Educação Ambiental, com a participação da sociedade civil e órgãos governamentais, tendo como resultado a Declaração de Brasília para EA.

Em 1994, em conseqüência da Constituição Federal de 1988 e ainda sob os efeitos da Rio92, é criado o Programa Nacional de Educação Ambiental (PRONEA). Três componentes são previstos: capacitação para gestores e educadores, desenvolvimento de ações educativas e desenvolvimento de instrumentos e metodologias. O programa foi executado pela Coordenação de Educação Ambiental do Ministério da Educação (MEC) e pelos setores correspondentes do Ministério do Meio Ambiente (MMA) e Ibama (MENDONÇA, 2004).

Em 1997, os PCNs trazem uma proposta de se trabalhar o currículo escolar com temas transversais, escolhidos pela urgência e abrangência de cada tema. Assim, oficialmente, o meio ambiente é introduzido nos currículos escolares brasileiros como um tema transversal. Apesar das escolas ainda não absorverem as propostas trazidas pelos PCNs - pela dificuldade de operacionalizála nas atuais situações em que encontra o ensino escolar - e das críticas feitas a esse documento - por não pensar a transversalidade sem alterar os eixos principais das disciplinas escolares e por não ter

\footnotetext{
${ }^{5}$ Entendemos aqui como viés conservacionista as práticas direcionadas à EA que se restringem à discussão somente dos aspectos físicos e biológicos. A EA mais progressista diferencia-se da educação conservacionista, na medida em que esta "trata do uso racional dos recursos naturais, o manejo produtivo de ecossistemas e outros fins", enquanto a EA "deve ser antes de mais nada uma educação política, voltada para uma mudança de valores" (BRÜGGER, 1998, p. 63)
} 
contado com a participação democrática de todos os atores educacionais (LOUREIRO, 2004a; MENDONÇA, 2004; SANTOS, 2002) - ainda assim os PCNs estruturam-se como um documento de referência para a escola ao trazer caminhos metodológicos para a inserção da temática ambiental na educação escolar, tornando-se um material de apoio importante para os educadores (CARVALHO, 2001; MEDINA, 2001; SATO, 2001; SORRENTINO, 2001).

A Política Nacional de Educação Ambiental (PNEA- lei 9795/99), instituída em 1999, dá subsídios para a prática de EA, reforçando sua inclusão em todos os níveis de ensino e definindo-a como:

(...) os processos por meio dos quais o indivíduo e a coletividade constroem valores sociais, conhecimentos e habilidades, atitudes e competências voltadas para conservação do meio ambiente, bem comum do povo, essencial à sadia qualidade de vida e sua sustentabilidade (SORRENTINO et al, 2005, s/p).

Em 2002, o Decreto 4281/02 regulamenta a PNEA e indica o MEC e o MMA como órgãos gestores dessa política. Atualmente a EA é contemplada nas políticas públicas através da Coordenação Geral de Educação Ambiental (CGEA/MEC) e da Diretoria de Educação Ambiental (DEA/MMA) (SORRENTINO et al, 2005).

Apesar de as conquistas da EA desde os anos noventa para cá terem sido significativas, pouco de concreto pode ser visualizado na sua consolidação em termos de políticas públicas e implementação do seu órgão gestor. A EA ainda encontra-se marginalizada pelo MEC (MENDONÇA, 2004) o que nos permite visualizar alguns caminhos possíveis e ainda em construção, mas não a sua concretização enquanto política pública de "caráter democrático, universal e includente" (LOUREIRO, 2004a, p. 88). Mesmo porque, segundo esse autor, "as orientações econômicas voltadas para os interesses do mercado continuam dominantes” (p. 88). Além disso, a EA vem sendo historicamente incorporada na educação formal e informal por políticas predominantemente governamentais, que na maioria das vezes agem através de seus órgãos de meio ambiente, em detrimento dos órgãos oficiais de educação e da sociedade civil, o que explica muito as dificuldades de organização, participação e totalização de suas práticas (LIMA, 2005). Ao mapear as experiências de EA desenvolvidas no Brasil, a comissão da "Primeira Conferência Nacional de Educação Ambiental" levantou problemas e desafios para a introdução da EA no ensino formal. Entre os problemas, quinze pontos foram levantados, dentre os quais a falta de material didático apropriado para trabalhos de EA nas escolas, o predomínio de um paradigma positivista e de uma 
pedagogia tecnicista que impedem o surgimento de modelos de EA integrados e interdisciplinares, a ausência de conceitos e práticas da EA que reforçam lacunas na fundamentação teórica dos pressupostos que a sustenta (BRASIL, 1997).

Porém, a despeito das dificuldades que a EA ainda encontra nas políticas públicas, observamos nos últimos anos uma expansão sem precedentes da EA no ensino formal. O censo escolar realizado em 2001, pelo Instituto Nacional de Estudos e Pesquisas Educacionais Anísio Teixeira (Inep), ao incluir duas questões relacionadas ao tratamento da EA nas escolas básicas, revelou que, do total de alunos do ensino fundamental do país, 71,2\% estudam em escolas que trabalham de alguma forma com EA. Essa porcentagem sobe para $73 \%$ se considerarmos os alunos das $5^{\mathrm{a}}$ a $8^{\mathrm{a}}$ série, ou seja, são 11,4 milhões de estudantes que estão em contato com a EA. O censo também distinguiu a existência de três maneiras, não excludentes, de a EA ser desenvolvida na escola: a inserção da temática ambiental através dos conteúdos das disciplinas $(55,4 \%)$, sob a forma de projetos $(29,6 \%)$ e sob a forma de uma disciplina específica (2,6\%)(BRASIL, 2002).

Veiga et al. (2005), ao analisarem os dados recolhidos pelo censo escolar no período de 2001 a 2004, concluíram que houve uma universalização da EA nas escolas, pois, se em 2001 61,2\% das escolas declararam trabalhar com EA, essa porcentagem sobe para 94\% em 2004, o que equivale a um aumento de $32 \%{ }^{6}$. Outra conclusão dessa pesquisa foi o aumento da preferência de se trabalhar com EA em forma de projetos. Entre os anos de 2001 e 2004 as escolas que inserem a temática ambiental através de trabalhos com projetos aumentaram 90\% (de 33,6 mil escolas que optam por essa modalidade em 2001 para 64,3 mil escolas em 2004). O trabalho com EA por meio de disciplinas especiais também obteve um aumento expressivo de 17\% (de 2,9 mil escolas que optam por essa modalidade em 2001 para 5,5 mil escolas em 2004). Mesmo assim, a incorporação da EA através da sua inserção nos conteúdos das disciplinas ainda é a maneira mais freqüente das escolas brasileiras (de 94 mil escolas que optam por essa modalidade em 2001 para 110 mil escolas em 2004) ${ }^{7}$.

\footnotetext{
${ }^{6}$ Essa pesquisa faz parte de um projeto intitulado "O que fazem as Escolas que dizem que fazem Educação Ambiental" realizado pelo o MEC, juntamente com o Inep, tendo como intuito mapear a expansão da EA nas escolas brasileiras. A primeira etapa é exatamente a análise dos resultados do censo escolar realizado pelo Inep nos períodos entre 2001 e 2004 feita por Veiga et al (2005). A segunda etapa da pesquisa tem uma abordagem mais detalhada e busca saber quais são os incentivos, prioridades, atores envolvidos, modalidades e resultados observados na incorporação da EA. A terceira e última etapa, ainda não realizada, pretende realizar pesquisas etnográficas e estudos de caso, para realizar uma análise mais profunda da presença da EA nas escolas (BRASIL, 2007b).

${ }^{7}$ Guerra e Guimarães (2007), em artigo que apresenta os resultados sistematizados do Grupo de Discussão e Pesquisa que aconteceu no III Encontro de Pesquisa em Educação Ambiental (EPEA), questionam a metodologia utilizada pelo
} 
Ora, chegamos assim em 2007 com um quadro de inclusão da EA ao ensino formal. A despeito da precariedade das políticas públicas, a temática ambiental já é uma realidade no currículo escolar, embora os números nos digam pouco sobre sua práxis. Mesmo que a inserção da temática ambiental seja atualmente uma realidade no ensino formal, sabemos das dificuldades e desafios que a EA ainda tem que enfrentar no dia-a-dia escolar. Por isso, nos perguntamos: de que maneira a temática ambiental tem sido trabalhada pelos atores escolares? É nesse sentido que acreditamos que o presente estudo, ao realizar um diagnóstico do modo como a EA vem sendo trabalhada nas escolas do município de Piracicaba/SP, poderá contribuir no processo de incorporação da EA ao ensino formal, ao desvelar as principais dificuldades, os recursos mais utilizados, as atividades, as disciplinas envolvidas com trabalhos com a questão ambiental e as concepções de EA dos professores, sendo, portanto, um instrumento para a melhoria das propostas e práticas de EA e, consequentemente, da qualidade da educação básica.

\subsection{As diferentes correntes da Educação Ambiental: uma diversidade de olhares e fazeres expressas no campo}

Situamos a EA em um contexto de crise ambiental, emergindo do movimento ambiental como uma resposta no âmbito da educação para a superação de tal crise. A recente história da EA já nos permite identificar alguns pontos característicos que, reunidos, nos remetem a um campo que, embora esteja ainda em construção e consolidação de suas bases epistemológicas, já tem seu reconhecimento e legitimação como uma educação voltada para o meio ambiente. Ao abraçar toda a problemática e temas relacionados ao meio ambiente o campo da EA torna-se vasto. Outro ponto marcante nesse campo é que desde seu início ele foi disputado por grupos sociais orientados por ideologias diferentes, que propõem diferentes maneiras de idealizar e praticar a EA. Logo, o que vemos é um campo que está longe de ser homogêneo, cuja dinâmica foi deste o início marcada por disputa de interpretações e significados de seus conceitos-chave. Assim, sob a denominação "Educação Ambiental" vemos um variado grupo de atores que, a partir de visões de mundos e práticas pedagógicas distintos, dão diferentes cores e sabores aos projetos político-pedagógicos daí

INEP na coleta de dados referentes a EA, uma vez que quem responde a pesquisa são os gestores das escolas, pessoas que " muitas vezes estão afastadas da realidade do cotidiano pedagógico (...) principalmente quando essas ações normalmente se colocam como atividades extra-curriculares, fugindo da rotina mais sistematizada do ambiente escolar" (p. 157), como é o caso da EA. 
originados (BRÜGGER, 1998; CARVALHO, 2002a, 2003, 2004, 1989, 2006; GRÜN, 1994; KRASILCHIK，1994; LIMA，1997，1999，2004，2005; LOUREIRO，2004a，2004b，2006; REIGOTA, 1998; SAUVÉ, 1997, 2005b; SORRENTINO, 2000; entre tantos outros). Mesmo que num primeiro momento sejamos levados a acreditar que exista um consenso nos valores, interesses e ideais dos indivíduos que compartilham esse campo, um olhar mais atento nos revela o quanto a EA reúne visões e fazeres diferenciados.

A concepção que temos de EA está diretamente ligada à nossa concepção de meio ambiente (REIGOTA, 2001) sendo que esse é um conceito cunhado socialmente:

Toda sociedade, toda cultura cria, inventa, institui uma determinada idéia do que seja a natureza. Nesse sentido, o conceito de natureza não é natural, sendo na verdade criado e instituído pelos homens. Constitui um dos pilares através do qual os homens erguem as suas relações sociais, sua produção material e espiritual, enfim, a sua cultura (GONÇALVES, 2004, p. 22).

Tanto para Marcos Reigota (2001) quanto para Aloísio Ruscheinsky (2001) a concepção de meio ambiente é uma representação social, pois não existe uma definição consensual desse termo nem na comunidade científica e nem fora dela. Assim, para esses autores é primordial que qualquer processo educativo ligado à EA deva ser iniciado pela identificação das representações de meio ambiente de todos os envolvidos:

(...) se meio ambiente está relacionado a um lugar determinado em que os elementos naturais e sociais se relacionam, então é preciso lançar um olhar sobre os problemas imediatos que envolvem a realidade do grupo social inserido nesse meio. Para identificá-los, a educação ambiental deverá buscar nas próprias expressões do grupo os passos a serem seguidos. Nesse processo, a educadora e o educador devem ter o cuidado de estabelecer uma prática a partir dessas representações e não apenas de suas próprias visões da realidade, para não incorrer em erros de práticas educativas tradicionais que se distanciam de uma relação mais participativa (RUSCHEINSKY, 2001, p. 29).

Vários autores corroboram dessa idéia (CARVALHO, 2003, 1989, 2006; CRESPO, 1998; LOUREIRO, 2006; SAUVÉ, 1997, 2005a; SATO, 1997 e outros) e consideram, ao analisar o campo da EA, as diversidades existentes em relação a visões de mundo - que dão significados distintos tanto para meio ambiente quanto para desenvolvimento sustentável - e opções pedagógicas que guiam as propostas do campo. Assim, temos que diferentes concepções de educação, ambiente e, 
mais recentemente, desenvolvimento sustentável ${ }^{8}$ resultam em diferentes maneiras de conceber e praticar a EA.

Sauvé (1997) elaborou mapas teóricos de concepções tipológicas que servem para auxiliar na análise das representações que influenciam os discursos e práticas dos educadores ambientais (Figura 1, Figura 2 e Figura 3). Em tais mapas, as concepções de educação, ambiente e desenvolvimento sustentável são apresentadas juntamente com as conseqüências para o campo teórico e prático da EA.

Esses mapas teóricos ilustram o mosaico de concepções de mundo e de modelos educacionais que podem influenciar a maneira como nos colocamos diante do campo ambiental, abrindo um leque de possibilidades aos educadores. Assim, ao assumirmos que a EA é antes de tudo um processo educativo, qualquer proposta relacionada a essa área deve trazer explicitadas as bases pedagógicas em que se apóia (Figura 1).

\begin{tabular}{|c|c|c|c|}
\hline Paradigma sócio-cultural & $\begin{array}{c}\text { Paradigma } \\
\text { associado }\end{array}$ & Principais características & Abordagem Pedagógica \\
\hline $\begin{array}{c}\text { Industrial: } \\
\text { "Lei do mais forte", com alta } \\
\text { competitividade e incentivo à } \\
\text { produtividade. }\end{array}$ & Racional & $\begin{array}{c}\text { Transmissão de conhecimento } \\
\text { pré-determinados (modelos } \\
\text { técnico-científicos). }\end{array}$ & $\begin{array}{c}\text { Apresentações formais; } \\
\text { "treinamentos". }\end{array}$ \\
\hline $\begin{array}{c}\text { Existencial: } \\
\text { Respeito pela natureza em }\end{array}$ & Humanístico & $\begin{array}{c}\text { Desenvolvimento ótimo de } \\
\text { aprendizagem, } \\
\text { "freedom to learn". }\end{array}$ & $\begin{array}{c}\text { Abordagem confluente na } \\
\text { ducação-natureza e na EA de } \\
\text { valores. }\end{array}$ \\
\hline $\begin{array}{c}\text { Simbiossinergético: Entre as } \\
\text { relações humanas, sociais e } \\
\text { naturais. }\end{array}$ & Inventivo & $\begin{array}{c}\text { Construção crítica de } \\
\text { conhecimentos para as } \\
\text { transformações sociais, } \\
\text { aprendizagem cooperativa. }\end{array}$ & $\begin{array}{c}\text { EA "grass-roots"; } \\
\text { EA socialmente crítica. }\end{array}$ \\
\hline
\end{tabular}

Figura 1 - A tipologia dos paradigmas educativos na Educação Ambiental (BERTRAND; VALOIS, 1992)

Fonte: Sauvé (1997)

O mesmo vale para as concepções de ambiente e desenvolvimento sustentável. Esse último termo, recentemente ligado à EA, pode ter diferentes dimensões no campo dependendo do

\footnotetext{
8 Correntes mais progressistas criticam o emprego do termo "desenvolvimento sustentável" por observar nessa expressão certo reforço à idéia de desenvolvimento conforme interesses econômicos ao invés de seu questionamento, e vêm optando pelo uso de termos como "sustentalibilidade" ou "sociedades sustentáveis". Apesar de estarmos cientes de todas as contradições, diferentes interpretações e das apropriações que esse termo vem sofrendo nas últimas décadas (LIMA, 1997), optamos por mantê-lo por entendermos que esse ainda é amplamente aceito e utilizado, sem, entretanto, deixar de concordar com as críticas e aspectos problemáticos que o termo carrega.
} 
entendimento que os atores lhe dão (Figura 2). Desta maneira, o desenvolvimento sustentável pode ser compreendido como um dos objetivos da EA ou mesmo como objetivo central da EA, nesse caso propondo uma mudança de terminologia, sendo substituído por "Educação para o Desenvolvimento Sustentável" (SAUVÉ, 1997).

O quadro de tipos de concepções sobre meio ambiente (Figura 3) ilustra como a nossa relação com o meio determina a abrangência que terá as ações educativas em EA. Na medida em que percebemos o ambiente composto nos seus mais diversos aspectos - sociais, econômicos, políticos, ecológicos, culturais, históricos, éticos, etc. - qualquer proposta educativa relacionada à EA terá um caráter mais desafiador por buscar mudanças efetivas na maneira como os indivíduos vêm se relacionando e na maneira como a sociedade se relaciona com a natureza. Restringir o conceito de meio ambiente é, assim, restringir o horizonte de possibilidades que a EA possui.

Para Sauvé (1997, 2005a, b) essas diferentes concepções podem co-existir. A autora defende que essa diversificação não deveria ser ignorada, ao contrário, é a partir de reflexões, questionamentos e discussões em relação às diferentes concepções de meio ambiente, educação e desenvolvimento sustentável, que os educadores deveriam formar suas próprias definições de EA, sendo que qualquer proposta de ação educativa nessa área deva ter claro essas representações. Optar pela valorização de uma dimensão em detrimento das outras é aderir a determinado enviesamento.

Assim, o que uma visão mais atenta ao campo da EA nos permite vislumbrar é a variedade de propostas que germinam e ganham espaços e legitimam-se enquanto práticas educacionais, desmistificando a idéia de consenso que poderia haver no campo. É nesse sentido que diversos autores se debruçam sobre a EA e tendem a distinguir as correntes que compõem o campo:

A noção de corrente refere-se aqui a uma maneira geral de conceber e de praticar a educação ambiental. Podem se incorporar, a uma mesma corrente, uma pluralidade e uma diversidade de proposições. Por outro lado, uma mesma proposição pode corresponder a duas ou três correntes diferentes, segundo o ângulo analisado. Finalmente, embora cada uma das correntes apresente um conjunto de características específicas que a distingue das outras, as correntes não são, no entanto, mutuamente excludentes em todos os planos: certas correntes compartilham características comuns (SAUVÉ, 2005b, p. 17). 


\begin{tabular}{|c|c|c|c|}
\hline $\begin{array}{c}\text { Concepção do } \\
\text { Desenvolvimento } \\
\text { Sustentável }\end{array}$ & Principais características & $\begin{array}{l}\text { Concepção do } \\
\text { ambiente }\end{array}$ & Paradigmas educativos \\
\hline $\begin{array}{c}\begin{array}{c}\text { Desenvolvimento } \\
\text { contínuo, com inovação } \\
\text { tecnológica e mercado } \\
\text { livre baseado no } \\
\text { crescimento econômico. }\end{array} \\
\text { CREDO: Crescimento } \\
\text { econômico, com princípios } \\
\text { neoliberais, que irão } \\
\text { resolver os problemas } \\
\text { sociais e ambientais }\end{array}$ & $\begin{array}{c}\text { Produtividade e } \\
\text { competitividade. } \\
\text { A ciência e a tecnologia } \\
\text { para o crescimento } \\
\text { econômico com respaldo } \\
\text { nos controles legais. }\end{array}$ & $\begin{array}{c}\text { Ambiente como } \\
\text { recurso para o } \\
\text { desenvolvimento e o } \\
\text { gerenciamento. Uso } \\
\text { racional dos recursos } \\
\text { para a sustentabilidade }\end{array}$ & $\begin{array}{c}\text { Paradigma racional: } \\
\text { "treinamentos", } \\
\text { transferência e informação } \\
\text { (científicas, tecnológicas e } \\
\text { legais). }\end{array}$ \\
\hline \begin{tabular}{l}
\multicolumn{1}{c|}{$\begin{array}{c}\text { Desenvolvimento } \\
\text { dependente na ordem } \\
\text { mundial. }\end{array}$} \\
CREDO: Os problemas \\
sociais serão resolvidos \\
pelo crescimento \\
econômico se houver um \\
controle pelas organizações \\
superiores.
\end{tabular} & $\begin{array}{c}\text { Mercado livre em grandes } \\
\text { escalas e inovações } \\
\text { científicas e tecnológicas } \\
\text { para reestruturação das } \\
\text { condições sociais. } \\
\text { Organizações: mundial ou } \\
\text { pactos regionais, acordos e } \\
\text { legislação. }\end{array}$ & $\begin{array}{c}\text { Toda a biosfera como } \\
\text { um "pool" de recursos } \\
\text { para ser gerenciado } \\
\text { pelas organizações } \\
\text { superiores. }\end{array}$ & $\begin{array}{c}\text { Paradigma racional: } \\
\text { mesma abordagem acima, } \\
\text { mas com uma aceitação da } \\
\text { possível falha do modelo } \\
\text { neoliberal. }\end{array}$ \\
\hline $\begin{array}{l}\quad \begin{array}{l}\text { Desenvolvimento } \\
\text { alternativo. }\end{array} \\
\text { CREDO: Somente uma } \\
\text { mudança global nos } \\
\text { valores e nas escolhas } \\
\text { sociais irá permitir um } \\
\text { desenvolvimento } \\
\text { sustentável nas } \\
\text { comunidades. }\end{array}$ & $\begin{array}{c}\text { Desenvolvimento } \\
\text { biorregional econômico: } \\
\text { com distinção das } \\
\text { necessidades e dos desejos, } \\
\text { redução da dependência, } \\
\text { utilização dos recursos } \\
\text { renováveis, estímulo aos } \\
\text { processos democráticos, } \\
\text { participação e } \\
\text { solidariedade. }\end{array}$ & $\begin{array}{l}\text { Ambiente como um } \\
\text { projeto comunitário. }\end{array}$ & $\begin{array}{l}\text { Paradigma inventivo: } \\
\text { projetos comunitários para } \\
\text { as transformações das } \\
\text { realidades sociais. }\end{array}$ \\
\hline $\begin{array}{l}\begin{array}{c}\text { Desenvolvimento } \\
\text { autônomo } \\
\text { (desenvolvimento } \\
\text { indígena) }\end{array} \\
\text { CREDO: } \\
\text { O desenvolvimento é } \\
\text { valorado se a manutenção } \\
\text { da identidade cultural e da } \\
\text { integridade territorial for } \\
\text { preservada }\end{array}$ & $\begin{array}{c}\text { Economia de subsistência, } \\
\text { baseada na solidariedade, } \\
\text { associada às distintas } \\
\text { cosmologias. }\end{array}$ & $\begin{array}{c}\text { O ambiente como } \\
\text { território (lugar para se } \\
\text { viver) e projetos } \\
\text { culturais comunitários. }\end{array}$ & \\
\hline
\end{tabular}

Figura 2 - Tipologia das concepções do Desenvolvimento Sustentável na Educação Ambeintal - Calgary Latin American Studies Group (1994)

Fonte: Sauvé (1997) 


\begin{tabular}{|c|c|c|c|}
\hline Ambiente & Relação & Características & Metodologias \\
\hline Como natureza & $\begin{array}{c}\text { Para ser apreciado e } \\
\text { preservado }\end{array}$ & $\begin{array}{c}\text { Natureza como catedral, } \\
\text { ou como um útero, pura } \\
\text { e original. }\end{array}$ & $\begin{array}{c}\cdot \text { Exibições; } \\
\text { • Imersão na natureza. }\end{array}$ \\
\hline Como recurso & Para ser gerenciado & $\begin{array}{c}\text { Herança biofísica } \\
\text { coletiva, qualidade de } \\
\text { vida. }\end{array}$ & $\begin{array}{l}\text { - Campanha dos 3Rs; } \\
\text { - Auditorias. }\end{array}$ \\
\hline Como problema & Para ser resolvido & $\begin{array}{c}\text { Ênfase na poluição, } \\
\text { deteriorização e } \\
\text { ameaças. }\end{array}$ & $\begin{array}{c}\text { - Resolução de } \\
\text { problemas; } \\
\text { - Estudos de caso. } \\
\end{array}$ \\
\hline $\begin{array}{c}\text { Como lugar para } \\
\text { viver }\end{array}$ & $\begin{array}{c}\text { EA para, sobre e no } \\
\text { para cuidar do } \\
\text { ambiente }\end{array}$ & $\begin{array}{l}\text { A natureza com os seus } \\
\text { componentes sociais, } \\
\text { históricos e tecnológicos }\end{array}$ & $\begin{array}{c}\bullet \text { Projetos de } \\
\text { jardinagem; } \\
\bullet \text { Lugares ou lendas } \\
\text { sobre a natureza. }\end{array}$ \\
\hline Como biosfera & $\begin{array}{c}\text { Como local para ser } \\
\text { dividido }\end{array}$ & $\begin{array}{c}\text { Espaçonave Terra, } \\
\text { "Gaia", a } \\
\text { interdependência dos } \\
\text { seres vivos com os } \\
\text { inanimados. } \\
\end{array}$ & $\begin{array}{c}\text { - Estudos de caso em } \\
\text { problemas globais; } \\
\text { - Estórias com diferentes } \\
\text { cosmologias. }\end{array}$ \\
\hline $\begin{array}{l}\text { Como projeto } \\
\text { comunitário }\end{array}$ & Para ser envolvido & $\begin{array}{l}\text { A natureza com foco na } \\
\text { análise crítica, na } \\
\text { participação política da } \\
\text { comunidade }\end{array}$ & $\begin{array}{c}\text { • Pesquisa(ção) } \\
\text { participativa para a } \\
\text { transformação } \\
\text { comunitária; } \\
\text { - Fórum de discussão }\end{array}$ \\
\hline
\end{tabular}

Figura 3 - A tipologia das concepções sobre o ambiente na Educação Ambiental (SAUVÉ, 1992, 1994) Fonte: Sauvé (1997)

Essa autora organizou um mapa de correntes em EA, na qual identifica a existência de quinze correntes, entre elas as de longas tradições (naturalista, conservacionista/recursista, resolutiva, sistêmica, científica, humanista e moral/ética) e as mais recentes (holística, biorregionalista, práxica, crítica, feminista, etnográfica, da ecoeducação e da sustentabilidade).

Ao elaborar um quadro teórico de concepções de EA, Marília F. de C. Tozoni-Reis (2002 e 2004), em uma pesquisa junto a professores universitários de cursos graduação de biologia, geografia e química das universidades públicas do Estado de São Paulo responsáveis pela formação de educadores ambientais, chegou a três tendências de EA. A primeira tendência, denominada de Natural, na qual há uma presença forte dos professores de biologia, onde as relações entre os homens e o ambiente são naturalizadas, não havendo atenção à mediação da cultura e da sociedade. Segundo 
essa tendência, a crise ambiental surge de um afastamento circunstancial entre o ser humano e o ambiente e é resultado da arrogância do homem em não se submeter à natureza. Os sujeitos históricos são substituídos por uma natureza vingativa e a relação homem-natureza passa a ter um caráter apocalíptico. A educação nessa tendência tem a função de reintegrar o homem à natureza, esvaziando a função do educador como mediador na interação do indivíduo com o meio natural, social e cultural. A educação passa a ter um caráter de mudança individualista para a construção de uma sociedade harmônica e equilibrada. A segunda tendência revelada pela autora é a Racional, em que há uma predominância de professores de química. Nessa concepção a relação homem-natureza é intermediada pelo conhecimento técnico-científico e o homem é um ser integrante da natureza, mas essa não é intocada. Cabe à EA, através dos conhecimentos científicos, a função de adaptar o indivíduo à sociedade e aos limites dos recursos naturais. O conhecimento aqui é supervalorizado e é produto de uma ciência neutra, com acúmulo de conhecimento por gerações. Educação é sinônimo de ensino e a prática educativa acaba sendo centrada na transmissão e aquisição de conhecimentos sobre o ambiente, tendo destaque o esgotamento dos recursos naturais. Tanto a tendência Natural quanto a Racional trazem uma perspectiva catastrófica embutida no discurso ecológico e minimizam os aspectos sociais e históricos da problemática ambiental ao mesmo tempo em que superestimam os aspectos físicos e biológicos. É na última e terceira tendência, denominada pela autora como Histórica, que os aspectos desconsiderados pelas demais tendências são contextualizados. Nessa tendência há um predomínio dos professores de geografia. A perspectiva histórica e social media a relação entre humanos e natureza, que passa a ser uma relação entre sociedade-natureza. E é essa visão que permeia o entendimento da crise ambiental e as soluções para sua superação. A educação busca o desenvolvimento de sujeitos históricos e sociais plenos e não é mais compreendida de forma isolada de outras práticas sociais. A educação é construída e construtora de relações sociais concretas.

Por sua vez, Luiz Marcelo Carvalho (1989), em sua pesquisa com os professores de ensino fundamental, chega a uma classificação com três grandes tendências de EA. A primeira é denominada por ele de Tradicional. A concepção predominante de EA dos professores dessa tendência é relacionada à preservação ou à conservação do ambiente ou da natureza. Há também uma ênfase na obtenção de conhecimentos sobre o meio ambiente e conscientização a respeito do mesmo. A natureza é entendida com uma fonte de recursos a ser dominada e explorada pelos homens, cabendo à EA desenvolver uma postura para que possamos explorar esses recursos 
racionalmente. Outros conceitos de EA presentes nessa tendência é relacioná-la a atitudes de manutenção de higiene corporal e do ambiente, adaptação do indivíduo ao ambiente e comportamentos adequados em diferentes ambientes. A segunda tendência revelada pelo autor foi denominada de Genérica por reunir um conjunto de respostas que pouco elucidou os entendimentos dos professores a respeito de EA. A concepção de EA nessa tendência ou é muito ampla, em que "tudo é Educação Ambiental”, ou por pouco explicitar a definição de EA, confundindo-a com a definição de ambiente ou mesmo com qualquer processo de educação informal. A última tendência revelada pela pesquisa foi denominada de Alternativa. Ela agrupa uma preocupação com os aspectos mais concretos do meio, com destaque para a importância das experiências e do cotidiano dos alunos, trazem um questionamento e o entendimento dos vários aspectos da relação entre sociedade e homem para o debate e acrescentam o aspecto afetivo ao tratarem a questão ambiental. São respostas que acabam trazendo à tona o que não era possível observar nas respostas reunidas nas outras duas tendências, mesmo, como salienta o autor, que de forma isolado e até um pouco ingênua.

As tendências expostas, juntamente com os mapas de concepções tipológicas elaborados por Sauvé (1997), apóiam a elaboração de um quadro de categorias de análise a serem utilizadas para efeito do presente estudo, a saber: Indefinida, Ingênua-romântica Convencional e Questionadora.

Apesar da pluralidade e variedade das propostas educacionais que germinam no campo da EA e os diferentes quadros de tendências formados por diversos autores, o que observamos é o fortalecimento de dois blocos antagônicos que acabam polarizando a disputa do campo (BRÜGGER, 1998; CARVALHO, 1991, 2001, 2003,2004; GUIMARÃES, 2004; GRÜN, 1996; LIMA, 1999 , 2002, 2004, 2005; LOUREIRO, 2004a, b, 2006; MATSUSHIMA, 1991; REIGOTA, 2001; entre outros) e que se firmam como pontos de referência político-pedagógicos das demais correntes da EA.

Assim, o primeiro bloco resulta em uma EA conservacionista, individualista e comportamentalista, denominado de EA Conservadora, Tradicional, Comportamental, Conservacionista ou Convencional, e estrutura-se como o hegemônico. Nasce como uma proposta alinhada à realidade socioambiental vigente. Apropria-se das idéias centrais do campo ecológico, o que lhe confere um perfil de mudanças, mas é incapaz de concebê-las por ser guiada por pensamentos superficiais e reducionistas de EA. As práticas educativas dessas correntes pouco podem contribuir para o estabelecimento de uma nova relação entre sociedade e ambiente e, assim, 
de superação da crise ambiental porque o que defendem é a manutenção do status quo. Seus principais pontos, com base nos autores já citados, são:

- Compreender a crise ambiental exclusivamente nas suas dimensões naturalista e conservacionista, priorizando a esfera natural em detrimento da social;

- A discussão da problemática ambiental fica restrita à esfera privada;

- O homem é genericamente dito como predador e destruidor da natureza ao mesmo tempo em que figura como vítima, um homem a-histórico;

- O papel da educação é de agente difusor de conhecimentos a respeito do meio ambiente, com o intuito de valorizar mudanças de hábitos e comportamentos predatórios para o que consideram ecologicamente corretos. É uma educação centrada no indivíduo, que consideram que as mudanças individuais irão desencadear mudanças sociais;

- Os esforços são concentrados nas crianças, uma vez que elas representam a geração futura;

- Por tudo isso a EA acaba sendo destituída das esferas sociais, políticas, culturais e históricas. É uma EA despolitizada;

- Prioriza a prática com foco na reciclagem e às vezes na redução do consumo, mas não eleva a discussão para o modo de produção. Direcionada ao ensino de ecologia, as atividades são voltadas para resolver problemas, como colocação de coletores seletivos de lixo, campanhas pontuais em defesa de um rio, entre outros, baseando-se em vivências práticas pontuais.

Lima (2002, 2005) destaca uma variante desse bloco conservador, que denomina de Conservacionismo Dinâmico. Para o autor essa tendência consegue captar os anseios de mudanças 
oriundos do campo da EA, mas se apropria dos ideais transformadores para garantir que nada seja alterado de maneira substancial:

Funciona através de mudanças 'cosméticas', superficiais dos fatos sem que sua essência fundamental seja alterada. (...) Seu aparente dinamismo, a influência enganadora que exerce sobre as representações e a compreensão da questão ambiental, a posição hegemônica que ocupa no interior do campo ambiental e da própria sociedade e a linguagem tecnocientífica utilizada que caracterizam sua expressão, tendem a legitimá-lo enquanto proposta que resulta na despolitização do debate e na desmobilização dos educandos e outros segmentos interessados na educação ambiental. Isto porque (...) utiliza um discurso ambíguo que simula e promete mudanças, mas deixa de dizer que as mudanças propostas não podem ultrapassar os limites da sociedade vigente (LIMA, 2005, p. 128).

Para o autor essa tendência se constitui como principal obstáculo para a consolidação de uma EA realmente comprometida com a transformação social. Corroboramos essa idéia à medida que analisamos a forma como a EA vem sendo incluída no ensino escolar. As ações pontuais e fragmentadas, ao mesmo tempo em que deixam a impressão de que alguma coisa está sendo feita, não permitem que a EA possa ser efetivamente incluída no currículo escolar. Essas atividades superficiais relacionadas à temática ambiental também geram muita frustração aos envolvidos, pois, após um longo período de trabalho e dedicação, os resultados não são satisfatórios, uma vez que se busca repostas rápidas. $\mathrm{O}$ sentimento de impotência cresce e gradualmente as atividades tornam-se mais desconectadas com a educação escolar.

Por sua vez, o bloco antagônico surge no bojo de desejos reais de mudanças do modelo social vigente. Defende novos valores e éticas nas relações entre os humanos e desses com o ambiente. Em síntese, esse bloco:

- Trata da problemática ambiental nas esferas pública e política e busca uma leitura crítica da realidade;

- Entende a relação sociedade-natureza de maneira dialética e num contexto da transformação da sociedade;

- Ambiente é compreendido como um todo complexo, no âmbito social, político, cultural, ético e ecológico; 
- Não há separação entre teoria e prática, subjetividade e objetividade, natural e cultural, saber científico e popular e assim por diante;

- Os sujeitos são sociais e históricos;

- O papel da educação é de formar sujeitos políticos capazes de transformar criticamente a sociedade. É um processo contínuo e permanente, sendo que todo e qualquer cidadão deve participar;

- A EA busca um movimento de ruptura com a ordem vigente e construção de novos valores sociais e éticos baseados na solidariedade, bem-estar público, democracia, respeito etc. Busca-se compreender os problemas trazidos pela crise ambiental como um todo e se possível apontar algumas soluções.

É nesse movimento de oposição às práticas de EA do bloco hegemônico que vários educadores ambientais estão repensando a EA, atribuindo-lhe novas dimensões e perfis: Crítica, Transformadora, Emancipatória, Popular ou até mesmo renomeações: Alfabetização Ecológica, Ecopedagogia, Educação no Processo de Gestão Ambiental. Todas com o compromisso de recolocar a educação e, em especial, a EA como um elemento importante para a construção de uma sociedade socialmente mais justa, ecologicamente sustentável e igualitária (LAYRARGUES, 2004). É dentro desse bloco que alinhamos a presente pesquisa, assim sintonizada com uma EA crítica, transformadora e emancipatória.

\subsection{A Educação Ambiental e suas especificidades: em defesa de uma educação que seja ambiental}

Ora, a despeito de todo o debate da questão ambiental e do histórico em que emerge a EA e suas tendências que vêm sendo apresentadas por nós até o momento, podemos nos perguntar: há realmente a necessidade de somar o adjetivo "ambiental" ao termo "educação"? De que forma essa união altera as propostas educativas que até então vinham sendo desenvolvidas? 
De fato, Tozoni-Reis $(2002,2004)$ nos alerta que a preocupação em relacionar educação e ambiente não é um fato novo e já se encontrava nos pensamentos de Comenius, Rousseau, Pestallozi, Froebel e Freinet. Carvalho (2003) também nos lembra que as metodologias educativas consagradas por Piaget e Paulo Freire, por exemplo, também já incorporavam a idéia do sujeito histórico, social e natural. Então, novamente, o que a EA traz de novo para a educação? Se de um lado temos que uma educação que não seja ambiental não é educação de forma alguma (GRÜN, 1996), do outro vemos o quanto a educação tradicional vem descuidando do seu papel dentro dos novos desafios trazidos pela questão ambiental.

É nesse contexto que a EA surge como uma resposta educativa em meio a crise ambiental (CARVALHO, 2003; MEDINA, 2001; SATO, 2001; TOZONI-REIS, 2002; entre outros). Para Loureiro (2004a, b), embora pareça ser uma redundância o uso do "ambiental", faz-se ele necessário à medida que esse adjetivo resgata dimensões que foram esquecidas e supridas pela educação tradicional:

(...) se é verdade que nem toda a educação é ambiental, em seu sentido complexo, paradigmático e histórico, é igualmente verdadeiro afirmar que todo processo educativo ocorre em um determinado ambiente, bem como argumentar que nem toda Educação Ambiental pressupõe o mesmo significado do que é ambiente e, principalmente, do que é educação (LOUREIRO, 2004a, p. 34).

É desta maneira que Carvalho (2003) acredita que uma EA realmente comprometida com as transformações sociais vai além de uma síntese das práticas educativas tradicionais da educação:

(...) tem a ver com o modo como esta EA revisita esse conjunto de atividades pedagógicas, reatualizando-as dentro de um novo horizonte epistemológico em que o ambiental é pensado como sistema complexo de relações e interações da base natural e social e, sobretudo, definido pelos modos de sua apropriação pelos diversos grupos, populações e interesses sociais, políticos e culturais que aí se estabelecem. O foco de uma educação dentro de um novo paradigma ambiental, portanto, tenderia a compreender, para além de um ecossistema natural, um espaço de relações sócio-ambientais historicamente configurado e dinamicamente movido pelas tensões e conflitos sociais (CARVALHO, 2003, p. 56).

Assim, embora a inquietação com a problemática ambiental já venha sendo incorporada pelas propostas educacionais há algum tempo, é apenas no final dos anos sessenta que se inicia a sistematização de propostas de EA como uma prática educativa dirigida para a superação da crise ambiental: "Educação", referindo-se a troca de conhecimentos, científicos ou não, mediando a 
relação entre os humanos e desses com o mundo que os cercam; “Ambiental", atribuindo à dimensão educativa características que vinham sendo suprimidas pela educação tradicional, resgatando práxis pedagógicas que com o tempo foram sendo esvaziadas de sentido e as contextualizam dentro de um cenário de crise ambiental. Os sentidos de educação e ambiente tornam-se amplos e, juntos, constroem uma proposta de práxis educativa que se propõe, juntamente com outras práticas sociais, mudar e transformar a relação entre sociedades e natureza.

É nesse sentido que para Naná Medina (2001) a EA torna a educação mais próxima da realidade, pois é um:

(...) processo que consiste em propiciar as pessoas uma compreensão crítica e global do ambiente, para elucidar valores e desenvolver atitudes que lhes permitam adotar uma posição consciente e participativa a respeito das questões relacionadas com a conservação e a adequada utilização dos recursos naturais, para melhoria da qualidade de vida e eliminação da pobreza extrema e do consumismo desenfreado. A Educação Ambiental visa à construção de relações sociais, econômicas e culturais capazes de respeitar e incorporar as diferenças (minorias étnicas, populações tradicionais), à perspectiva da mulher e à liberdade para decidir caminhos alternativos de desenvolvimento sustentável (MEDINA, 1998 apud MEDINA, 2001, p. 17-18).

Loureiro (2002) também define a EA como:

(...) uma práxis educativa e social que tem por finalidade a construção de valores, conceitos, habilidades e atitudes que possibilitem o entendimento da realidade de vida e a atuação lúcida e responsável de atores sociais individuais e coletivos no ambiente. Nesse sentido, contribui para a tentativa de implementação de um padrão civilizacional e societário distinto do vigente, pautado numa nova ética da relação sociedade-natureza (LOUREIRO, 2002, p. 69).

Sauvé (2005a) descarta a EA como uma educação no meio de tantas outras ou como uma ferramenta para solucionar problemas. A autora define a EA como:

(...) uma dimensão essencial da educação fundamental que diz respeito a uma esfera de interações que está na base do desenvolvimento pessoal e social: a da relação com o meio em que vivemos, com essa 'casa de vida' compartilhada (...) visa a induzir dinâmicas sociais, de início na comunidade local e, posteriormente, em redes mais amplas de solidariedade, promovendo a abordagem colaborativa e crítica das realidades socioambientais e uma compreensão autônoma e criativa dos problemas que se apresentam e das soluções possíveis para eles (SAUVÉ, 2005a, p. 317). 
Já problematizamos anteriormente o quanto a supervalorização da EA enquanto prática educativa é prejudicial para a estruturação de uma proposta político-pedagógica que realmente possa contribuir para alterar o quadro contemporâneo de crise ambiental. Focar na educação como única possibilidade de mudanças sociais, criando-se uma "ilusão pedagógica" (NAGLE, 1974 apud CARVALHO, 2006, p. 21), sem que seus limites sejam demarcados, é uma maneira de esvaziar de sentidos e poder de mobilização a ação educativa. Já contextualizamos o quanto é imprescindível vislumbrar a dimensão educativa tanto no que se refere às suas possibilidades quanto aos seus limites, uma vez que a construção de uma prática político-pedagógica comprometida se dá juntamente com outras práticas sociais. Nessa perspectiva que procuramos entender o quanto de contribuição a EA pode trazer ao ser inserida no currículo escolar. Sendo a escola um espaço historicamente importante para a formação do cidadão e estando conectada diretamente com a sociedade e com os temas que se colocam como atuais e urgentes, a EA coloca-se como colaboradora efetiva na formação de sujeitos concretos, capazes de se posicionarem diante dos desafios trazidos pela questão ambiental e de fazerem uma releitura do mundo. A EA traz novo fôlego à educação escolar ao aproximar o "viver escolar" do "viver real". É bem verdade que esse processo de aproximação entre a EA e a escola não tem sido fácil, sendo que muitos obstáculos existentes no espaço escolar podem impossibilitar que essa união ocorra (KRASILCHIK, 1986, 1994). Sinalizamos que o modo como a educação vem sendo tradicionalmente desenvolvida não tem cumprido seu papel social, fazendo necessário surgir uma educação que seja ambiental. A escola precisa mudar e essa mudança coloca-se como um desafio aos educadores, caso contrário teremos uma EA praticada em atividades pontuais, muitas vezes não indo além dos conteúdos já tradicionalmente incluídos nas disciplinas de Ciências, Biologia e Geografia.

\subsubsection{Situando a Educação Ambiental no Ensino Formal: possibilidades e limites}

É dentro desse espírito que nos entregamos nesse momento ao levantamento de algumas características que acreditamos ser fundamental para a construção de uma proposta de EA comprometida com o processo educativo transformador. Sabemos que o limite deste trabalho não permitirá um aprofundamento das características por nós discutidas, mas nossa intenção é de contribuir para o debate da inserção da EA na educação formal. Assim, em sintonia com os autores 
já citados e com os princípios da EA Transformadora, Crítica e Emancipatória que atribuímos alguns pressupostos que julgamos imprescindíveis para que a EA seja incorporada ao ensino formal e possa auxiliar na formação de cidadãos - não apenas aptos a viverem na sociedade, como também capazes de questioná-la e, assim, promover mudanças.

\subsubsection{A dimensão política}

Não compreender a EA a partir de um prisma político é negar o quanto o fazer e pensar nesse campo foi historicamente ampliado, deixando de ser exclusivamente conservacionista e preservacionista e avançando para uma visão mais totalizante das relações entre os humanos e desses com a natureza. Já pontuamos o quanto os conceitos-chave da EA são disputados por atores sociais com forças e interesses distintos e da impossibilidade de supor que exista um consenso no campo. Entender a EA enquanto uma prática pedagógica que surge da necessidade de rever a relação entre sociedade e natureza e da sociedade consigo mesma é legitimá-la no campo educativo, um campo em que não há possibilidade de conceber a prática educativa como uma prática neutra (FREIRE, 2002) e ao mesmo tempo em que assume o "ambiental" como um qualificador que diferencia a EA de uma educação que não seja ambiental. Para Lima (2002) ou a EA é política ou não tem sentido em se falar em uma EA comprometida com a transformação da realidade socioambiental, pois sem a dimensão política a EA converte-se em uma prática educativa que serve aos interesses do modelo social vigente. Porém, conceber a EA a partir do prisma político é articulá-la a outras práticas sociais democráticas que caminham para a construção de novos valores éticos, sociais e políticos que sustentam as relações entre sociedade e natureza.

É nesse sentido que realinhamos a EA na formação de cidadãos capazes de problematizar a questão ambiental e transformar a realidade, com o compromisso de:

(...) garantir os processos de sociabilidade, em construir, tanto entre as sociedades e a natureza como entre os diferentes serres humanos, relações que valorizem a vida e por isso tornam-se humanizadoras, caracterizando essa prática social como politicamente compromissada (CARVALHO, 2006, p. 23).

Vários educadores ambientais já vinham preconizando a importância da EA ser vista como uma ação política. O princípio quatro do Tratado de EA para Sociedades Sustentáveis e 
Responsabilidade Global já assumia que a EA “não é neutra, mas ideológica. É um ato político". Contudo, Carvalho (2006) alerta para a distância entre o reconhecimento da EA como processo político e sua realização na prática, como se "apenas nomear a educação ambiental como ação política garante às suas práticas, a priori, força de transformação social” (p. 23). Essa ruptura entre o discurso e a prática faz com que a EA seja na maioria das vezes incorporada no ensino formal de maneira despolitizada. Para Krasilchik (1986) o que existe é uma dificuldade e despreparo dos professores em lidar com questões polêmicas, que exigem um debate politizado mais profundo e formações de juízos de valores. Além disso, para a autora, a relação autoritária entre professores e alunos não permite que se estruture um diálogo mais franco na sala de aula.

Trazer para a EA uma perspectiva política é reconhecer também que ela deva se desenvolver também a partir de critérios democráticos e participativos. Com a participação dos sujeitos no processo de politização e no exercício da cidadania não há lugar para transmissão e assimilação de conhecimentos, tão valorizados pela escola tradicional e tecnicista - nomeada de educação bancária pela pedagogia freiriana. Uma EA que seja política, democrática e participativa está comprometida com a transformação individual e coletiva.

Dessa maneira, a EA também necessita ser uma educação crítica que ao conscientizar o indivíduo o instrumentalize para formar um olhar crítico em relação à sociedade e que possibilita:

(...) ao educando questionar criticamente os valores estabelecidos pela sociedade, assim como os valores do próprio educador que está trabalhando na sua conscientização. É permitir que o educando construa o conhecimento e critique valores a partir de sua realidade, o que não significa um papel neutro do educador que negue os seus próprios valores em sua prática, mas que propicie ao educando confrontar criticamente diferentes valores em busca de uma síntese pessoal que refletirá em novas atitudes (GUIMARÃES, 1995, p. 31-32).

Paulo Freire (2002) diferencia entre duas práticas educativas, a primeira sendo denominada de prática domesticadora e a segunda de prática libertadora. Enquanto a primeira há "a dimensão manipuladora nas relações entre educadores e educandos em que, obviamente, os segundos são os objetos passivos da ação dos primeiros" (p. 104), na libertadora os educandos são "convidados a participar criadoramente do processo de sua aprendizagem” (p. 104). Assim, para o autor a “educação para a 'domestificação' é um ato de transferência de conhecimento” enquanto na pedagogia libertadora a educação "é um ato de conhecimento e um método de ação transformadora 
que os seres humanos devem exercer sobre a realidade”(p. 105). A superação da primeira para a práxis libertadora se dá, nas palavras de Freire:

(...) o educador para a libertação tem de "morrer" enquanto exclusivo educador dos educandos no sentido de renascer, no processo, como educador-educando dos educandos. Por outro lado, tem de propor aos educandos que também "morram" enquanto exclusivos educandos do educador para que renasçam como educandoseducadores do educador-educando (FREIRE, 2002, p. 108).

Uma EA que for desenvolvida dentro das perspectivas da educação domestificadora certamente será igualmente despolitizada, opressora e transmissora de conhecimentos. Paula Brügger (1998) denominou essa de adestramento ambiental por justamente não trazer os questionamentos históricos das relações sociedade-natureza e por priorizar um processo técnico de instrução. A politização da problemática ambiental e da EA é considerar o "educando como portador de direitos e deveres, a abordagem do meio ambiente como um bem público e o tratamento do acesso a um ambiente saudável como um direito de cidadania” (LIMA, 2002, p. 134).

Assim, é no domínio político que a EA vai sendo construída democraticamente, buscando, no âmbito escolar, o desenvolvimento de práticas pedagógicas que contribuam para a formação de indivíduos autônomos e ativos, por isso cidadãos, que sejam capazes de questionar e de tomar decisões. A educação deve orientar os indivíduos capazes de pensar sozinhos, que tenham consciência da sua realidade e capacidade transformadora (FREIRE, 1983, 2002) e, portanto, possam atuar na transformação da sociedade.

\subsubsection{O pertencimento}

Acreditamos que o conceito de pertencimento também deva ser um dos pilares da EA, principalmente no que tange sua inserção na educação formal. Por tudo que viemos colocando até então, podemos dizer que a crise ambiental também represente uma crise de pertencimento:

A ideologia individualista da cultura industrial capitalista moderna construiu uma representação da pessoa humana como um ser mecânico, desenraizado e desligado de seu contexto, que desconhece as relações que o tornam humano e ignora tudo que não esteja direta e imediatamente vinculado ao seu próprio interesse e bem-estar (SÁ, 2005, p. 247). 
Obviamente que esse sentimento de desenraizamento está presente na educação e faz-se sentir na escola.

A transformação deste padrão é obviamente um problema educacional, no seu sentido mais amplo e intrínseco, psico-cultural e sócio-político, pois se trata de fazer emergir do inconsciente coletivo da humanidade suas experiências de pertencimento, trazer para a luz da consciência os conteúdos ocultos na sombra de nossa solidão como partes desgarradas de um mundo partido (SÁ, 2005, p. 248).

Nesse sentido, a EA surge como uma prática educativa que pode auxiliar no resgate do pertencimento do educando com seu mundo e, consequentemente, com a própria escola, afinal "a noção de pertencimento, do fazer parte, do estar incluído, é fundamental para que este processo de transformação passe a acontecer, aliado aos elementos da crítica social" (NOAL, 2003, p. 72). Assim, os sentimentos de solidariedade, amor e respeito trazem o enraizamento do indivíduo na sociedade e sua co-responsabilidade com as questões ambientais. A valorização da afetividade é outro aspecto que deve compor a EA por incluir no processo educativo outras dimensões existentes na relação entre os indivíduos e a natureza.

Acreditamos também que a dimensão local/global da problemática ambiental deve ser incluída no resgate de pertencimento do indivíduo:

A educação ambiental se realizará de forma diferenciada em cada meio para que se adapte às respectivas realidades, trabalhando com seus problemas específicos e soluções próprias em respeito à cultura, aos hábitos, aos aspectos psicológicos, às características biofísicas e socioeconômicas de cada localidade. Entretanto, deve-se buscar compreender e atuar simultaneamente sobre a dinâmica global (...) para que não haja uma alienação e um estreitamento de visão que levem a resultados pouco significativos (GUIMARÃES, 1995, p. 37).

Ao não fazer essa conexão entre a realidade local e a realidade global, o educador corre o risco de não dar conta da totalidade da questão ambiental. Carvalho (1989) aponta dois erros comuns que acontecem no ensino formal: o primeiro é o professor centrar-se apenas nos aspectos particulares da realidade dos seus alunos, isolando essa realidade local e esquecendo-se de fazer as pontes com o restante do mundo, o que pode estreitar a visão de mundo dos alunos e "a questão toda resume-se naquilo que se entende por realidade do aluno" (p. 231). O segundo risco levantado pelo o autor é que se ocorra o oposto, ou seja, o professor concentre o debate com seus alunos nos desastres 
ecológicos de dimensões mundiais e, desta maneira, secundariza o estudo das realidades próximas aos alunos.

A crise que se apresenta para a humanidade já nasce globalizada e seus efeitos são sentidos em todos os cantos do mundo, independentemente do poder político e econômico do país. Ao despertar em cada indivíduo o sentimento de pertencimento, de responsabilidade e participação na busca das soluções, tanto locais como globais, dos graves problemas ambientais estamos convidando-os a tomar partido diante da crise que nos é colocada. Não só em assumir seu compromisso político e engajamento individual, mas também em exigir políticas públicas que sejam igualmente compromissadas com a superação da questão ambiental e na busca da melhoria da qualidade de vida planetária.

\subsubsection{Processo contínuo e permanente}

Obviamente que estamos defendendo um processo educativo que seja contínuo e permanente e que, por isso, ultrapasse as barreiras espaciais e temporais da educação escolar. Assim como a EA ao ser incorporada pela escola não pode restringir-se aos conteúdos específicos de nenhuma disciplina ou mesmo na criação de uma disciplina específica ou ainda se desenvolver a partir de projetos pontuais, acreditamos também que suas atividades não podem concentrar-se nas primeiras séries iniciais da educação básica. Mais uma vez recorremos às palavras de Paulo Freire (2005) que ao reconhecer o humano como ser histórico o tem como ser inconcluso:

(...) como seres inacabados, inconclusos, em e com uma realidade que, sendo histórica também, é igualmente inacabada. Na verdade, diferentemente dos outros animais, que são apenas inacabados, mas não são históricos, os homens se sabem inacabados. Têm a consciência de sua inconclusão. Aí se encontram as raízes da educação mesma, como manifestação exclusivamente humana. Isto é, na inconclusão dos homens e na consciência que dela têm. Daí que seja a educação um quefazer permanente. Permanente, na razão da inconclusão dos homens e do devenir da realidade (FREIRE, 2005, p. 83-84, grifo nosso). 


\subsubsection{Os novos saberes}

A crise ambiental traz consigo o alerta da impossibilidade do conhecimento forjado na ciência moderna ser, sozinho, capaz de compreender a complexidade da problemática ambiental e assim de superá-la. Aliás, Mauro Grün (1994) é um entre os que advogam que a modernidade potencializou e globalizou a crise ecológica. Para o autor, a visão cartesiana-newtoniana é de uma natureza morta, uma fonte de recursos inesgotáveis que estão a disposição dos homens, de maneira desigual. O processo de conhecimento acontece a partir da ruptura do homem com a natureza, assim a ciência moderna baseia-se na dicotomia entre natureza e sociedade, fato e valor e entre ciência e ética. O paradigma moderno não consegue pensar o ser humano e a natureza conjuntamente, é necessária uma abordagem reducionista e fragmentada que divide o "todo em partes". Embora esse método tenha conseguido avanços científicos importantes, ao ser usado para compreender uma realidade mais complexa torna-se ineficaz, pois a soma das partes não representa o todo (MORIN, s/d). Assim, novos saberes são necessários para que possamos compreender a complexidade existente na relação ser humano-sociedade-natureza.

O saber científico é produzido socialmente, carregando consigo toda a disputa de poder e contradições existentes nas sociedades que o produzem (SANTOS, 1988). Se a ciência não é ideologicamente neutra, sofre influência do meio social em que é forjada e, consequentemente, não é socialmente autônoma, por que seria neutro e autônomo o conhecimento por ela gerado? A educação escolar vem historicamente assimilando, valorizando e sistematizando o conhecimento científico, transmitindo-o de forma compartimentada nas disciplinas curriculares. E esse conhecimento é transmitido aos educandos sob a ótica de uma verdade indiscutível e absoluta. Desta maneira, todo

esse sistema de valores da ciência moderna, que vem sendo consolidado desde os séculos XVI e XVII, acaba por influenciar a educação escolar e:

(...) se faz presente no currículo das escolas na forma de padrões culturais. Tais padrões perpassam a educação das séries iniciais à universidade e assumem a forma de mitos. Os livros textos podem nos ilustrar um mito importantíssimo da educação moderna, talvez o mais importante no que se refere a nossa relação com a natureza - o antropocentrismo (GRÜN, 1994, p. 177).

Ao ser tratada na sala de aula, a natureza acaba tendo uma abordagem prioritariamente descritiva, que tanto pode enaltecer a beleza das paisagens naturais quanto tratá-la de maneira 
depreciativa, considerando-a inimiga do ser humano (CARVALHO, 1989). Também para Leff (2007), a crise ambiental também se apresenta como uma crise de conhecimento, uma vez que somos nós que concebemos o ambiente com o nosso saber. Devemos lembrar que o conceito de meio ambiente é cunhado socialmente. Daí a impossibilidade de pensar a questão ambiental dentro do paradigma dominante:

A complexidade da questão ambiental decorre do fato de ela se inscrever na interface da sociedade com o seu-outro, a natureza. A dificuldade em lidar com ele, nos marcos do pensamento herdado, é evidente: no mundo ocidental, natureza e sociedade são termos que se excluem. As ciências da natureza e as do homem vivem em dois mundos à parte e, pior, sem comunicação. Não há como tratar a questão ambiental nesses marcos. Hoje sabemos que essa é uma das formas de se organizar o saber, não é a única! Nas diversas regiões do conhecimento científico, percebemos a inquietação que se manifesta no questionamento dos seus fundamentos (GONÇALVES, 2004, p. 140).

É na tentativa de romper com esse processo de objetificação da natureza que a EA estrutura-se no diálogo entre os saberes, “(...) saberes ligados às ciências biofísicas e humanas, saberes tradicionais, da experiência, do senso comum etc. (...)” (SAUVÉ, 2005a, p. 321). Saberes distintos que interpretam o mundo diferentemente, abrindo outros horizontes de entendimento e formas de se relacionar com o meio ambiente que não apenas o apresentado pelo conhecimento científico. Portanto, busca-se romper com interpretações da realidade que são reducionistas, fragmentadas e unidimensionais, uma vez que:

Unidades complexas, como o ser humano ou a sociedade, são multidimensionais: dessa forma, o ser humano é ao mesmo tempo biológico, psíquico, social, afetivo e racional. A sociedade comporta as dimensões histórica, econômica, sociológica, religiosa (...). O conhecimento pertinente deve reconhecer esse caráter multidimensional e nele inserir estes dados: não apenas não se poderia isolar uma parte do todo, mas as partes umas das outras (MORIN, 2003, p. 38).

Assim, as dimensões biológicas, sociais e culturais exigem um currículo escolar que vá além das possibilidades que proporciona a disciplinaridade imposta na educação escolar atual. O não resgate do UNO pode significar fazer-se uma ciência sem homem, consequentemente vazia de sentido (FAZENDA, 1987). A ruptura entre social/natural, teoria/prática, ciência/senso comum, objetividade/subjetividade etc. pode perpetuar-se na relação indivíduo-sociedade-natureza enquanto 
perdurar o paradigma da ciência moderna. Busca-se assim uma integração das dimensões que compõem a relação entre humanos e natureza:

(...) articular simultaneamente todas as dimensões do relacionamento entre educação, a sociedade e o ambiente num conhecimento e ação complexos que ultrapassem as fronteiras dos saberes, das disciplinas cientificas e das instituições, no sentido da construção de novos diálogos e sínteses, de um conhecimento multidisciplinar e de parceiras e redes entre os vários agentes da sociedade. Isso aponta para uma articulação multidimensional entre ecologia, educação, política, cultura, economia, ética e tecnologia e, ainda que em nível preliminar, para o lançamento de pontes entre os saberes tradicionais, científicos, populares, religiosos e filosóficos; a comunicação das disciplinas entre si e o estabelecimento de parcerias entre os diversos segmentos sociais pertencentes à sociedade cível, ao Estado e ao setor privado (LIMA, 2005, p. 138).

Mas qual saber dará conta da complexidade e do entendimento da crise ambiental, permitindo que caminhemos na busca de um novo paradigma? Como a educação em geral e a EA poderão auxiliar no repensar da relação indivíduo-sociedade-natureza? Para Leff (2001) um dos princípios em que a EA se funda é na busca de uma nova visão de mundo, diferente da visão atualmente dominante:

A educação ambiental insere-se, assim, dentro de um processo estratégico que estimula a reconstrução coletiva e a reapropriação subjetiva do saber. Isto implica em que não há um saber ambiental pronto e já dado, que se separe e se insere nas mentes dos alunos, mas sim um processo educativo que fomenta a capacidade de construção de conceitos (...) a partir de suas 'significações primárias' (LEFF, 2001, p. 121).

Mais uma vez trazemos a importância de a EA ser desenvolvida dentro de um processo participativo. As atividades de EA nas escolas acontecem muitas vezes sem que haja a participação de todos os atores escolares no processo. Desconsideram-se as múltiplas concepções de meio ambiente dos educandos e educadores e a EA, invariavelmente, realiza-se sob o ponto de vista de um especialista que transmitirá valores e atitudes corretos a respeito da natureza (MEYER, 2001). Para essa autora, os educandos percebem o ambiente em seus múltiplos aspectos, "mas sentem dificuldades em interpretar os fenômenos e situações ambientais a partir do enfoque biológico e em incorporar os impactos dentro de um contexto cultural'(p. 89). Assim como Reigota (2001) e Ruscheinsky (2001), a autora defende que é através do saber já existente dos educandos e educadores que deve ser iniciado o trabalho educativo da EA. Posteriormente esses saberes deverão 
ser analisados e criticados para que, após uma reflexão, possam ocorrer mudanças na visão de mundo desses indivíduos. A participação de alunos e professores torna-se dessa maneira essencial para que uma postura crítica possa ser desenvolvida e a educação, ao contrário de ser a assimilação de conteúdos prontos e acabados e esvaziados de sentidos, seja um processo construído por todos.

É nesse contexto de articulação entre as dimensões política, ética, cultural, econômica, tecnológica, ecológica e educacional e no diálogo entre os saberes que se forjará um novo saber, que Leff (2001) denomina de saber ambiental. E nesse sentido que, para o autor, o saber ambiental não será o resultado da soma dos conhecimentos existentes, mas será construído a partir de uma nova racionalidade ambiental.

\subsubsection{Por uma ética ambiental}

A crise ambiental é uma crise eminentemente da ética moderna, de valores que regulam a relação indivíduo-sociedade-natureza. Para Lima (1999) a dimensão ética e a dimensão política formam os eixos centrais da EA. Para Carvalho (2002a) a busca para a constituição dessa nova ética colide com a composição de uma racionalidade ambiental e de um sujeito ecológico e juntos afirmam-se:

(...) contra uma ética dos benefícios imediatos e uma racionalidade instrumental utilitarista que rege o homo economicus e a acumulação das sociedades capitalistas. O campo ambiental, portanto, busca afirmar-se na esfera das relações conflituosas entre ética e racionalidade que organizam a vida em sociedade, buscando influir numa certa direção sobre a maneira como a sociedade dispõe da natureza e produz determinadas condições ambientais (CARVALHO, 2002a, p. 37).

Conforme dito anteriormente, a visão de mundo cartesiana-newtoniana fundada a partir da ciência moderna e que vem sustentando-a, traz consigo valores que precisam ser questionados e rompidos, pois a natureza é "desantropormofizada e um poderoso império intelectual é construído sobre este objeto inerte e passivo" (GRÜN, 1994, p. 174). Dois são os aspectos da filosofia cartesiana que Carlos Gonçalves (2004) destaca na modernidade: o primeiro é o caráter pragmático do conhecimento, “conhecimentos que sejam úteis à vida” (p. 33); assim, a natureza não passa de um recurso usado pelos seres humanos. O outro aspecto é o antropocentrismo. Esse permite ao homem 
colocar-se no centro do mundo, o que o leva a ter uma posição oposta à natureza, que passa a ser objeto:

Poderíamos dizer, sem exagero nenhum, que a ética antropocêntrica é como se fosse a consciência do mecanicismo. Tal ética se afirma em consonância com a virada epistemológica caracterizada pelo abandono da concepção organísmica da natureza em favor de uma concepção mecanicista. A idéia aristotélica de natureza como algo animado e vivo, naquela as espécies procuram realizar seus fins naturais, é substituída pela idéia de uma natureza sem vida e mecânica. A natureza de cores, tamanhos, sons, cheiros e toques é substituída por um mundo 'sem qualidades'. Um mundo que evita a associação com a sensibilidade (GRÜN, 1996, p. 27).

A separação entre homem e natureza também leva à ruptura da relação homem-homem. Essa relação acaba tendo o "mesmo caráter atribuído à relação homem-natureza (sujeito-objeto), instrumentalizando, assim, as relações sociais" (GONÇALVES, 2004, p. 138).

É nesse cenário cartesiano que ocorrem as estruturações conceituais dos currículos que formarão a base da educação moderna. Além das características já apontados da visão de mundo cartesiana-newtoniana, Grün (1996) acredita que essa filosofia também se manifesta na educação moderna por aquilo que o autor chama de áreas de silêncio:

As áreas de silêncio do currículo não são simplesmente saberes sufocados pelas classes dominantes. Isto, é claro, quase sempre ocorre no processo de seleção dos conteúdos escolares que integram o currículo. (...) as áreas de silêncio do currículo são fruto de um dualismo lógico-estrutural presente na relação entre o 'tipicamente moderno' e a 'tradição'; o moderno toma seu lugar às custas de um esquecimento (GRÜN, 1996, p. 49).

Desta forma, o meio ambiente é quase que completamente apagado do currículo escolar. "O silêncio 'acontece' quando percebemos que existe uma ausência absoluta de referências ao fato óbvio de que tais atividades só podem se dar 'dentro de um ambiente físico'. A natureza é esquecida, recalcada e reprimida. Ela é silenciada" (GRÜN, 1996, p. 51). Imprime-se assim nas propostas educativas voltada para a questão ambiental, segundo Lima (1999), uma contradição pedagógicofilosófica por se idealizar uma prática "integradora e pluridisciplinar sobre uma estrutura de pensamento de base cartesiana, dualista e fragmentada, condicionada por uma ética antropocêntrica e utilitária" (p. 146). 
É nesse sentido que para Grün (1996) não há possibilidade de a EA se desenvolver no cenário cartesiano que é a base da educação moderna:

Sabemos que qualquer tentativa de preservação ambiental dentro do paradigma cartesiano é literalmente impossível (...) O que acontece quando tentamos elaborar um discurso pra a educação ambiental é que, muitas vezes, criamos o que denomino de 'situações recorrentes tecnicamente fundadas'. As situações recorrentes caracterizam-se por se manterem em uma posição estática na histórica. Isso ocorre quando no próprio discurso que visa preservar a natureza introduzimos, imperceptivelmente, aqueles mesmos elementos que são responsáveis por sua degradação (autonomia da razão, natureza objetificada, ética utilitarista, ética antropocêntrica, cisão entre natureza e cultura etc.). (...) Tais situações, em se tratando de educação ambiental, tomam a forma de uma pedagogia redundante, ou seja, uma pedagogia que não tem dinamismo compreensivo. Em certo sentido, um discurso ambientalista pautado pela pedagogia redundante é um discurso que nega aquilo que ele próprio pretende afirmar (GRÜN, 1996, p. 56-57).

Dessa maneira, qualquer tentativa de desenvolver a EA dentro do atual contexto escolar, contexto esse fundado na concepção de mundo cartesiana-newtoniana, irá prender-se no paradigma que deseja transformar, uma vez que há no paradigma dominante uma restrição discursiva para compreender a complexidade das questões ambientais (VEIÉGAS, 2002 apud GUIMARÃES, 2003). Os saberes sistematizados pela escola, ao invés de superar, produzem e reproduzem a impossibilidade de compreender a crise socioambiental em sua totalidade resultando, portanto, uma pedagogia redundante.

Busca-se, assim, uma nova relação com a natureza e uma nova relação entre os humanos, mediada por uma ética e um saber que sejam ambientais. De certo que essas buscas não ocorrerão de maneira fácil e conciliatória, uma vez que as soluções são procuradas dentro da ciência moderna e esta tem sido incapaz de colocar-se à frente dos desafios trazidos pela crise socioambiental que ela própria vem alimentando. É dessa maneira que Guimarães (2003) defende a ruptura com o paradigma moderno que cria, segundo o autor, limitações compreensivas e incapacidade discursa, gerando práticas conservadoras.

Embora estejamos longe da concretização de caminhos que nos levem a romper com o paradigma dominante, algumas possibilidades vão sendo construídas. Grün (1996) é um dos autores que elege a hermenêutica como filosofia orientadora para que se abandone a abordagem reducionista e objetificante imposta pelo cartesianismo, pois essa "situa sempre o ser humano no mundo, na história e na linguagem e não como um sujeito senhor de si, separado dos objetos” (p. 102). A 
hermenêutica permite, segundo o autor, que as áreas de silêncio existentes no currículo escolar sejam tematizadas:

A hermenêutica permite-nos perscrutar o sentido oculto, interrogar pelo sentido das ausências, esgueirar-se nas entrelinhas do texto e das realidades sociais do currículo (...) constitui-se em uma abordagem privilegiada porque traz a possibilidade de perguntar por aquilo que o cartesianismo não deixou que viesse à tona, o não dito. E é justamente o não dito que representa, talvez, uma das melhores possibilidades de encontrarmos práticas e saberes ecologicamente sustentados (GRÜN, 1996 p. 107).

Guimarães (2003), apoiando-se nas obras de Paulo Freire, Edgar Morin e outros, acredita na reflexão crítica como possibilidade de surgimento do novo, abandonando as certezas do paradigma da ciência moderna e imprimindo assim o movimento da práxis:

A reflexão crítica não se fia na estabilidade das certezas, do já conhecido; não se acomoda na visão simplificadora e reducionista da realidade, mas vai buscar os nexos contidos nas interações e inter-relações das partes com o todo e do todo com as partes (...). A reflexão crítica se abre para o novo, para as incertezas, que, tornando-as referências, relativiza-se as verdades complexificando-as. Essas reflexão crítica que busca a complexidade, permite práticas transformadoras, críticas e criativas, buscando superar a reprodução na construção do inédito (GUIMARÃES, 2003, p. 109)

De certo que esse movimento de abandono e ruptura com o paradigma dominante é um processo gradual e coletivo e, como já bem pontuado por Grün (1996), essa é uma preocupação há algum tempo incorporada pelo movimento ambientalista de cunho mais filosófico e diversas outras áreas do saber e começa também a fazer parte das indagações da EA.

\subsubsection{O princípio da interdisciplinaridade}

É nesse sentido, de entender a crise ambiental decorrente de vários aspectos e de constatar a fragmentação do ensino em áreas isoladas, que a interdisciplinaridade desponta como um princípio metodológico privilegiado da educação ambiental (GUIMARÃES, 2003; LEFF, 2001), embora seja importante salientar que essa não foi forjada no campo da EA. O campo ambiental resgata a proposta interdisciplinar que há muito tempo tinha caído no esquecimento. As indagações do campo 
interdisciplinar nos remetem aos tempos dos sofistas e romanos e retorna com grande impacto no século XIX com o advento da especialização e, a despeito da sua longa história, o conceito de interdisciplinaridade não é único e nem estável, variando a sua interpretação conforme vai sendo apropriado pelos processos educativos (FAZENDA, 1987). É na ausência de um consenso em torno do conceito desse termo que ocorrem as primeiras dificuldades de se realizar um trabalhado interdisciplinar no ambiente escolar. Carvalho (1989) sinaliza existir desde uma simplificação do termo, "reduzindo as propostas a atividades corriqueiras de coordenação entre diferentes disciplinas" (p.236), como também uma confusão entre os significados de interdisciplinaridade e transdisciplinaridade ${ }^{9}$, sendo os termos usualmente colocados como equivalentes. Para o autor o trabalho interdisciplinar inicia-se e alimenta-se dos conhecimentos já existentes. Leff (2001) corrobora dessa visão e defende que a "interdisciplinaridade ambiental não é nem a somatória nem a articulação de disciplinas; menos ainda se dá à margem destas” (p. 115), e completa:

O ensino interdisciplinar no campo ambiental implica na construção de novos saberes, técnicas e conhecimentos e a sua incorporação como conteúdos integrados no processo de formação. Ele requer um processo de autoformação e a formação coletiva da equipe de professores, quanto à troca sobre diversas temáticas ambientais, de elaboração de estratégias docentes e definição de novas estruturas curriculares (LEFF, 2001, p. 116).

Sato (1997) fortalece esse pensamento e acredita que a interdisciplinaridade ocorre “(...) fundamentalmente na natureza da realidade (ontológico), no conhecimento (epistemológico) e em como os atores (ideológico) que estão envolvidos atuam (metodológico) no processo" (p. 19). Assim, na educação escolar a interdisciplinaridade chega para superar a fragmentação do currículo e, ao buscar reorganizar os conhecimentos de maneira mais integrada, busca um entendimento da complexidade da questão ambiental e uma visão que mostre a interdependência da dimensão natural e social. Mas Carvalho (1989) alerta para o fato de a abordagem interdisciplinar ser encarada como

\footnotetext{
9 Existem várias maneiras de se interpretar os conceitos de interdisciplinaridade e de transdisciplinaridade. Para Jantsch a transdisciplinaridade "exige uma coordenação de todas as disciplinas em um sistema de inovação educativa, a partir de uma axiomática epistemológica" (JANTSCH, 1972 apud SATO, 1997, p. 21). As disciplinas ainda permanecem no ensino escolar, embora com um caráter renovado. Carvalho (1989) acredita que na transdisciplinaridade não existe limites entre as disciplinas, ocorreria uma reestruturação radical tanto do conhecimento quanto da organização curricular. Para o autor o caminho da transciplinaridade seria o caminho da superciência, "com as mesmas ambições e preconceitos hoje presentes nas ciências particulares; correm-se os riscos de assumir um caráter impositivo e, ao mesmo tempo, negar a possibilidade do diálogo, do exercício efetivo da interdisciplinaridade" (p. 236).
} 
mais um modismo na educação escolar. O autor acredita que sua incorporação deva ocorrer através de numerosas e diversificadas experiências, devidamente acompanhadas por trabalhos de avaliação e pesquisa.

De certo que a escola possui diversos empecilhos para que ocorra a interdisciplinaridade (CARVALHO, 1989; FAZENDA, 1987; GONÇALVES, 1994; KRASILCHIK, 1986). A estrutura disciplinar cria barreiras entre as pessoas, que Carvalho (1989) acredita ser o primeiro obstáculo que se coloca ao trabalho interdisciplinar. Fazenda (1987) destaca outros obstáculos, como a hierarquização das disciplinas, dificuldades de organizar metodologicamente a equipe interdisciplinar, a formação do educador (como o educador cuja formação tenha sido fragmentada pode engajar-se num trabalho interdisciplinar? De que forma ocorrerá trocas entre as disciplinas se ainda o educador não dominou o conteúdo específico da sua?) e o fato de muitos dos projetos interdisciplinares desenvolvidos na escola serem realizados sem que os educadores conheçam seus objetivos, sendo um processo de cima para baixo.

O trabalho interdisciplinar exige nova postura do educador e lança novos desafios à estruturação da educação escolar:

(...) pressupõe educadores imbuídos de um verdadeiro espírito crítico, abertos para a cooperação, o intercâmbio entre as diferentes disciplinas, o constante questionamento ao saber, arbitrário, cristalizado e desvinculado da realidade. Por outro lado, exige a prática de pesquisa, a troca, a sistematização de idéias, a construção do conhecimento, em um processo de indagação e busca permanente. Mas, acima de tudo, pressupõe a clareza dos fins, a certeza do porquê da interdisciplinaridade (GONÇALVES, 1994, p. 468-469).

Os PCNs foram a primeira proposta oficial para a reorganização do currículo escolar a partir da introdução de temas transversais. A proposta brasileira inspirou-se na experiência espanhola de reformulação do ensino formal (SEGURA, 2001 apud MORENO, 1998). Segundo o autor, essa última parte de um núcleo da Educação Moral e Cívica, onde os temas transversais passavam a ser o eixo sobre o qual girariam as áreas curriculares. Já na proposta trazida nos PCNs aconteceria o contrário. Os temas eleitos como transversais seriam incorporados nas disciplinas escolares Assim, a estrutura disciplinar da escola não seria alterada. Esse foi um dos pontos que mais os educadores criticaram nas pospostas dos PCNs. Para Medina (2001), a EA poderia ser o eixo integrador dos temas transversais, o que facilitaria a integração desses no currículo escolar. 
De certo que as práticas educativas voltadas para a questão ambiental não se encontram prontas, estando longe de existir uma fórmula mágica para orientar os educadores. É nesse sentido que acreditamos ser esse um processo em construção, onde modelos são testados. Alguns instrumentos importantes, como a realização de trabalhos em equipe e trabalhos com projetos ambientais abrangentes já são conhecidos na escola e podem auxiliar nesse caminho (MEDINA, 2001). Acreditamos, assim, que através do trabalho interdisciplinar as disciplinas escolares poderão contribuir decisivamente para o entendimento da problemática ambiental, contemplando todas as dimensões relacionadas ao assunto e possibilitando que a questão ambiental seja, de fato, um tema transversal no currículo escolar (GUIMARÃES, 2003).

É verdade que essas características da EA levantadas por nós representam apenas uma primeira contribuição do que supomos ser o desenho de uma práxis educativa voltada ao meio ambiente na educação formal, estando longe de ser conclusiva. Porém, acreditamos que tal exercício faz-se necessário a todos que abraçam a EA como prática educativa, uma vez que nenhum educador irá encontrar uma fórmula pronta em um livro didático. Sabemos o quanto ainda a EA precisa caminhar e ter suas bases epistemológicas consolidadas para que possa legitimar-se enquanto campo de conhecimento. Porém, se de um lado o campo da EA constitui-se como complexo e multidimensional e ainda esteja em construção, o que pode trazer insegurança e medo aos que atuam no campo, por outro, esse estágio inacabado da EA abre um leque de possibilidades para os atores sociais participarem efetivamente da sua estruturação. Nas palavras de Lima (2002):

(...) vivemos diante de opções por modelos de sustentabilidade e de educação mais reprodutivistas ou mais emancipatórios. Á primeira vista, reproduzir o conhecimento parece ser sempre uma opção mais segura que arriscar a inovação. Ocorre que diante de processos sociais degenerativos, que presenciamos no cotidiano e testemunhamos em tempo real pelos canais midiáticos (...), a opção pela inércia e pela conservação do velho significa aprofundar os processos de crise que hoje vivemos. Por outro lado, embora a aventura transformadora suponha uma relativa dose de incerteza, ela continua sendo a única que pode nos tirar da inércia e permitir a possibilidade de uma renovação construtiva da ética, da cultura e das sociedades atuais (LIMA, 2002, p. 138).

A escolha por uma EA que se oponha ao modelo social vigente coloca novamente nas mãos dos educadores e dos educandos a possibilidade de mudanças, não sendo os primeiros apenas transmissores de conhecimentos prontos e neutros, apresentado como uma verdade indiscutível, e os segundos receptores passivos e incapazes de tomarem as rédeas da sua educação. Assim, é de suma 
importância para aqueles que se propõem a desenvolver atividades educativas voltadas para a questão ambiental saberem diferenciar entre a EA "que todos fazem" da EA que se proponha a construir uma proposta político-pedagógica capaz de auxiliar nas mudanças sociais tão necessárias e almejadas. Assim, reconhecemos e abraçamos a EA que carrega consigo a potencialidade de ser uma educação transformadora, crítica e libertadora. 


\title{
3 REFERENCIAL METODOLÓGICO
}

\begin{abstract}
(...) cada teoria social é também uma teoria pessoal que inevitavelmente expressa e coordena as experiências pessoais dos indivíduos que a propõem. Muito do esforço do homem para conhecer o mundo ao seu redor resulta de um desejo de conhecer coisas que lhe são pessoalmente importantes.
\end{abstract}

\section{Alvin Gouldner}

\subsection{A pesquisa científica e a crise de paradigmas}

Caracterizamos anteriormente o momento em que vivemos como sendo de crise ambiental, uma crise que se mostra generalizada e, por isso, faz eco no paradigma da ciência moderna. Assim, esse também é um cenário onde há questionamentos relativos ao conhecimento científico.

A ciência moderna é, resumidamente, consagrada a partir das mudanças de paradigma que ocorre entre os séculos XVI e XVII. Mudanças essas que rompem com a forma de pensar da Idade Média, onde até então predominava uma visão de mundo baseada no conceito aristotélico de espaço qualitativo e, a partir de pensadores como Galileu, Bacon, Descartes e Newton, passa a ter uma perspectiva de representação do mundo quantitativa (GRÜN, 1996). Nasce assim a visão de mundo cartesiano-newtoniana que sustenta até os dias atuais o paradigma da ciência moderna:

A ciência moderna, na busca da verdade e rigor científico, separa o objeto do sujeito, o reduz e divide em partes. A natureza passa a ser vista como uma soma mecânica das partes, dessacralizada, passiva de ser domada, reorganizada e explorada (FOLADORI, 2001). As conseqüências não se restringem à dicotomia entre sujeito/objeto, mas desdobram-se também entre natureza/cultura, razão/emoção. O conhecimento é assim fragmentado e isolado em áreas de especializações e a relação sociedade-natureza é intermediada por uma ética predominantemente antropocêntrica. Gonçalves (2004) resume:

O século XIX será o do triunfo desse mundo pragmático, com a ciência e a técnica adquirindo, como nunca, um significado central na vida dos homens. A natureza, cada vez mais um objeto a ser possuído e dominado, é agora subdividida 
em física, química, biologia. O homem em economia, sociologia, antropologia, história, psicologia, etc. Qualquer tentativa de pensar o homem e a natureza de uma forma orgânica e integrada torna-se agora mais difícil. (GONÇALVES, 2004, p. 34)

De certo que o conhecimento científico moderno ao legitimar-se enquanto paradigma dominante proporciona ao conhecimento humano uma extraordinária evolução (MORIN, 1996; SANTOS, 1988). Porém, na contramão desses avanços cada vez mais vislumbramos os seus limites e contradições. Assim, o próprio progresso da ciência moderna expõe seus limites e as fragilidades de seus alicerces, nas palavras de Edgar Morin (1996):

(...) essa ciência elucidativa, enriquecedora, conquistadora e triunfante, apresentanos, cada vez mais, problemas graves que se referem ao conhecimento que produz, à ação que determina, à sociedade que transforma. Essa ciência libertadora traz, ao mesmo tempo, possibilidades terríveis de subjugação. Esse conhecimento vivo é o mesmo que produziu a ameaça do aniquilamento da humanidade. Para conceber e compreender esse problema, há que acabar com a tola alternativa da ciência "boa", que só traz benefícios, ou da ciência "má", que só traz prejuízos. Pelo contrário, há que, desde a partida, dispor de pensamento capaz de conceber e de compreender a ambivalência, isto é, a complexidade intrínseca que se encontra no cerne da ciência. (MORIN, 1996, p. 16).

Começa a ser desenhado uma crescente crítica ao paradigma dominante e é no cerne dessas críticas que se inicia um movimento de sua superação e busca de um novo modelo paradigmático. Nesse sentido, para muitos autores vivemos em um momento de transição de paradigmas (CARVALHO, 2004; GRÜN, 1994, 2002; MORIN, 1996; SANTOS, 1988; TOZONI-REIS, 2003; VEIGA-NETO, 1994; entre outros). Veiga-Neto (1994) descreve esse momento de transição paradigmática da seguinte maneira:

(...) tudo se passa como se estivéssemos vivendo numa fase de transição semelhante àquelas em que viveram Platão e Descartes, para quem as velhas ordens eram, respectivamente, o mundo homérico e o mundo aristotélico-tomista. O que hoje parece, para muitos de nós, antigo e a ser ultrapassado é aquele mundo desenhado pela Nova Ciência, do século XVII para cá. Como muitos ainda não sabemos o que virá, parece que vivemos, especialmente nessa última década do milênio, a perplexidade de um mundo que não é mais mas que também ainda não $e ́$ (VEIGA-NETO, 1994, p. 151). 
O momento de transição paradigmática presente ainda nos é muito nebuloso, marcado por incertezas, dúvidas e suposições. Estamos entre o velho e novo, entre o que é e o que pode ser. Para Boaventura de Sousa Santos (1988) ainda que sejam incertos os caminhos para as quais essa transição de paradigmas poderá nos levar, a "caracterização da crise do paradigma dominante traz consigo o perfil do paradigma emergente" e que as especulações a respeito do que esse autor chama de ciência pós-moderna estão fundadas "nos sinais que a crise do paradigma atual emite mas nunca por eles determinada" (p. 59-60).

\subsection{A pesquisa em Educação Ambiental}

A pesquisa em EA não fica imune às turbulências trazidas pela busca do novo paradigma, pois "a crise de paradigmas pela qual passa a produção científica nos últimos tempos exige, para pensarmos a pesquisa em educação ambiental, refletirmos sobre a crise de paradigmas nas ciências e na sociedade" (TOZONI-REIS, 2003, p. 13). Assumir as lacunas existentes na sua pesquisa é abrir novas possibilidades para um maior aprofundamento metodológico e também de fortalecimento epistemológico. Coloca-se, portanto, um desafio para todos aqueles que adentram ao seu campo de reflexão e atuação.

É nesse contexto de busca de novos paradigmas que a EA vai se firmando enquanto campo de conhecimento e construindo sua práxis, a fim de superar os limites e fragmentações que se encontram no bojo do conhecimento moderno. De fato, o campo da EA não tem ainda seus paradigmas de pesquisa prontos, de modo que o "caminho é definir a contextualização, a qual é congruente com o significado do contexto e, por sua vez, com o pensamento ambiental, como a melhor forma de compreender a concepção sistêmica"; assim, "o método não se aprende, cria-se" (TRISTÃO, 2004, p. 32). Nessa procura de uma metodologia guiada por paradigmas alternativos que prestigiem um enfoque qualitativo, alguns referenciais teórico-filosóficos começam a se firmar na EA, como a hermenêutica (CARVALHO, 2002a, GRÜN, 1996), o materialismo históricodialético (TOZONI-REIS, 2004) e a pesquisação/pesquisa-ação (SATO, 1997).

Para Myriam Krasilchik (2001), foram os próprios limites da metodologia quantitativa que levaram o questionamento de seus métodos, objetivos e significados na pesquisa em EA: 
Assim como a discussão sobre a natureza da pesquisa científica influiu no conteúdo dos projetos Educação Ambiental, também provocou transformação da metodologia adotada pela maioria dos pesquisadores educacionais assumindo que a decisão não era apenas técnica, mas dependia das convicções do investigador (KRASILCHIK, 2001, p. 44).

Assim, no início da década de setenta, tínhamos uma predominância na escolha de pesquisas em EA com abordagens quantitativas, porém já há algum tempo observamos uma mudança e procura de métodos alternativos (GIL, 2005; SATO, 1997). É nas Ciências Sociais, particularmente na área de educação, que a EA vai buscar parâmetros metodológicos e assume como suas as indagações, (in)certezas e desejos da pesquisa qualitativa:

Se a educação ambiental é uma estratégia de intervenção social, cuja meta está a transformação das ações dos indivíduos no ambiente, levando em conta o caráter histórico e social dessas intervenções, a pesquisa em educação ambiental refere-se a fenômenos humanos e sociais, históricos e culturais que não podem ser medidos apenas quantitativamente, mas compreendidos em sua totalidade e complexidade, interpretados e analisados sob a ótica qualitativa (TOZONI-REIS, 2003, p. 14)

Ao investigar uma identidade para a pesquisa em EA, Tozoni-Reis (2005) levanta cinco pontos que a caracterizam, a saber:

1. Reafirmar a potencialidade educacional da EA, tendo assim como objetivo principal da pesquisa em EA a produção de "conhecimentos pedagógicos para a consolidação da dimensão ambiental na educação" (p. 270). De fato, o resgate do caráter educativo na EA é o primeiro passo para a busca de novos paradigmas de metodologia para sua pesquisa (SAUVÉ, 1997, 2005a; SATO, 1997; TOZONI-REIS, 2003; entre outros). Para Sato (1997), a dimensão educativa na EA possibilita a busca de um método capaz de uma "reflexão crítica histórica, valorativa e ética que seja ancorada nas práticas sociais" (p. 138);

2. A escolha de métodos que priorize uma abordagem essencialmente qualitativa;

3. A adequação metodológica da pesquisa em EA, para que essa não engesse o pesquisador, tendo certa “(...) flexibilidade para adaptar-se aos diferentes temas e objetivos", mas também não perca o horizonte científico, tendo um "rigor metodológico 
adequado para apontar caminhos e garantir legitimidade à produção dos conhecimentos sobre os processos pedagógicos próprios desta área” (TOZONI-REIS, 2005, p. 271).

4. A relevância social da pesquisa em EA, portanto, recusa a suposta neutralidade científica e reafirma o seu compromisso em ser "ambiental e socialmente significativos" (p. 271);

5. A especificidade da pesquisa em EA, com seus princípios teórico-metodológicos e, assim sendo, tendo suas necessidades investigativas enquanto “(...) um processo coletivo, dinâmico, complexo e contínuo de conscientização e participação social que articule também a dimensão teoria e prática, além de ser um processo necessariamente interdisciplinar" (p. 271).

O presente trabalho corrobora as idéias até aqui enunciadas. E para um entendimento das escolhas metodológicas feitas, apresentamos a seguir as escolhas e os caminhos percorridos durante o processo de pesquisa.

\subsubsection{A trajetória da pesquisa}

Em concordância com as idéias até aqui enunciadas e os objetivos propostos, optamos por uma metodologia de abordagem essencialmente qualitativa.

São muitas as vantagens da abordagem qualitativa nas pesquisas educacionais, como de “apreender o caráter complexo e multidimensional dos fenômenos em sua manifestação natural”, como também permitir "capturar os diferentes significados das experiências vividas no ambiente escolar de modo a auxiliar a compreensão das relações entre os indivíduos, seu contexto e suas ações" (ANDRÉ, 1983, p. 66). Para a autora, a pesquisa qualitativa também contribui com outros aspectos importantes, como criatividade e pensamento crítico, que dificilmente poderiam ser investigados numa abordagem quantitativa e, por isso, muitas vezes deixam de ser investigados adequadamente pelo pesquisador.

Para Maria Cecília Minayo (2003) a pesquisa qualitativa preocupa-se: 
(...) com um nível de realidade que não pode ser quantificado. Ou seja, ela trabalha com o universo de significados, motivos, aspirações, crenças, valores e atitudes, o que corresponde a um espaço mais profundo das relações, dos processos e dos fenômenos que não podem ser reduzidos à operacionalização das variáveis (MINAYO, 2003, p. 21-22).

Ao elucidar as características da pesquisa qualitativa, Bogdan e Biklen (1982), citados por Lüdke e André (1986, p. 11-13), levantam cinco pontos:

1. A pesquisa qualitativa tem o ambiente natural como sua fonte direta de dados e o pesquisador como seu principal instrumento;

2. Os dados coletados são predominantemente descritivos;

3. A preocupação com o processo é muito maior do que com o produto;

4. O significado que as pessoas dão as coisas e a sua vida são focos de atenção especial pelo pesquisador;

5. A análise dos dados tende a seguir um processo indutivo.

Minayo (2003), ao tratar da metodologia da pesquisa qualitativa, a compara a uma espiral que começa "com um problema ou uma pergunta e termina com um produto provisório capaz de dar origem a novas interrogações" (p. 26), portanto, o ciclo nunca se fecha. A autora denomina esse processo como ciclo da pesquisa e o divide em três fases: começando primeiro com uma fase exploratória da pesquisa, que é "dedicado a interrogar-nos preliminarmente sobre o objeto, os pressupostos, as teorias pertinentes, a metodologia apropriada e as questões operacionais para levar a cabo o trabalho de campo" (p. 26); logo em seguida vem o trabalho de campo, onde o pesquisador pode utilizar e combinar várias técnicas de coletas de dados, como entrevistas, observações e levantamento de material, "momento relacional e prático de fundamental importância exploratória, de confirmação ou refutação de hipóteses e construção de teorias" (p. 26); o tratamento do material recolhido em campo é a fase que finaliza o ciclo de pesquisa e subdivide-se em três etapas, ordenação, classificação e análise propriamente dita. 
As críticas mais freqüentemente feitas às pesquisas qualitativas são relativas aos critérios de julgamento dos trabalhos científicos. Muitos críticos questionam a suposta falta de objetividade, rigor e controle científico, o que poderia resultar em um viés do pesquisador com o objeto pesquisado.

Marli André (1989) vai buscar nas Ciências Sociais artifícios para que o pesquisador possa lidar com a subjetividade que inevitavelmente aparece na pesquisa de campo, sugerindo o "estranhamento" como:

Uma atitude de policiamento contínuo do pesquisador para transformar o familiar em estranho. É um esforço ao mesmo tempo teórico e metodológico: por um lado deve-se jogar com as categorias teóricas para poder ver além do aparente e por outro treinar-se para "observar tudo" para "enxergar" cada vez mais, tentando vencer o obstáculo do processo naturalmente seletivo da observação (ANDRÉ, 1989, p. 43).

A autora também distingue outras formas que poderiam auxiliar o pesquisador no controle da subjetividade. A primeira é a prática do trabalho individual de pesquisa, "o trabalho de pesquisa, principalmente o que se volta aos processos sociais, deveria no mínimo tentar refletir esta diversidade de perspectivas" (p. 43). A outra seria o processo coletivo de trabalho, que, se possível, deveria ser interdisciplinar, pois geralmente trabalha-se com temas "passíveis de enfoques divergentes" (p. 43). Em outro trabalho, André (2006) sugere outros critérios para julgamento científico, como a triangulação (de método, sujeito e perspectiva) e acrescenta que "a plausibilidade substitui a validade, a credibilidade surge no lugar da fidedignidade e a 'transferência' é usada para se contrapor à generalização" (LINCOLN; GUBA, 1985 apud ANDRÉ, 2006, p. 51). Mirian Goldenberg (2000), baseando-se em Max Weber, Pierre Bourdieu e Howard Becker, acredita que a explicitação de todos os passos dados pelo pesquisador e a consciência das interferências de seus valores na pesquisa, "introduzindo as premissas valorativas de forma explícita nos resultados da pesquisa" (p. 45) é uma maneira de enfrentar a subjetividade existente na pesquisa qualitativa.

Uma outra questão muito freqüente na pesquisa qualitativa é sua relação com a pesquisa quantitativa. Sobre esse assunto, Minayo (2003) esclarece:

A diferença entre qualitativo-quantitativo é de natureza. Enquanto cientistas sociais que trabalham com estatísticas apreendem dos fenômenos apenas a região "visível, ecológica, morfológica e concreta", a abordagem qualitativa aprofundase no mundo dos significados das ações e relações humanas, um lado não 
perceptível e não captável em equações, médias e estatísticas (MINAYO, 2003, p. 22).

Mas a autora nega qualquer oposição que possa existir entre as duas abordagens, "ao contrário, se complementam, pois a realidade abrangida por eles interage dinamicamente, excluindo qualquer dicotomia" (p. 22).

\subsubsection{A entrevista e a coleta de dados}

Dentre as técnicas de coleta de dados da pesquisa qualitativa optamos pela utilização da entrevista. Além disso, a coleta de dados foi complementada com observações e anotações feitas pela pesquisadora durante a visita nas escolas selecionadas para o desenvolvimento da presente pesquisa.

Para Lüdke e André (1986), a entrevista, ao lado da observação, é um dos instrumentos básicos para coleta de dados. Para essas autoras, a vantagem na utilização dessa técnica é a captação imediata das informações desejadas. Haguette (1992) define a entrevista "como um processo de interação social entre duas pessoas na qual uma delas, o entrevistador, tem por objetivo a obtenção de informação por parte do outro, o entrevistado" (p. 75). Cruz Neto (2003) alerta para o fato de a entrevista não ser confundida como uma simples conversa entre os atores sociais, feita de uma forma “despretensiosa e neutra, uma vez que se insere como meio de coleta dos fatos relatados pelos atores, enquanto sujeitos-objetos da pesquisa que vivenciam uma determinada realidade que está sendo focalizada" (p. 57).

Viertler (2002) classifica a entrevista em três tipos: a inteiramente estruturada, com seus tópicos previamente fixados; a parcialmente estruturada, que em há uma combinação entre os tópicos fixos e os que são redefinidos conforme o andamento da entrevista; e a não estruturada, em que não há tópicos fixos e o diálogo segue livre entre o entrevistador e o entrevistado. Para essa autora "as entrevista estruturadas dão um maior controle da situação ao pesquisador, (enquanto) as não estruturadas dão um maior controle para o informante" (p. 17).

Para a presente pesquisa, utilizamos uma entrevista parcialmente estruturada, em que um roteiro foi elaborado para orientação do andamento das entrevistas. Porém, a utilização de um roteiro não impediu a interação entrevistador-entrevistado, de modo a garantir certa flexibilidade para o entrevistador e para o entrevistado (Apêndices 1 e 2). 
O primeiro contato com as escolas selecionadas para a pesquisa foi feito através do telefone, com os coordenadores ou diretores. Um horário de visita à escola era marcado de acordo com as possibilidades dos coordenadores e professores que seriam entrevistados, assim como os horários e locais das entrevistas foram sempre estabelecidos pelos entrevistados. As entrevistas das escolas estaduais aconteceram nos horário de trabalho pedagógico coletivo (HTPC) e horário de trabalho pedagógico (HTP). E as entrevistas das escolas da rede particular aconteceram nos intervalos, "janelas" entre as aulas, horários de entrada ou de saída. Todas as entrevistas foram realizadas nas dependências das escolas selecionadas, sendo gravadas com autorização prévia dos entrevistados e, posteriormente, transcritas. Dentre os participantes da pesquisa, somente uma coordenadora não autorizou sua gravação, sendo as informações anotadas no momento em que a entrevista estava sendo realizada.

Os coordenadores ou diretores indicaram, dentro do corpo docente, quais eram os professores que abordavam a temática ambiental em suas aulas. Além disso, em algumas ocasiões os próprios professores indicaram outros colegas. Assim, houve dois critérios de escolha dos entrevistados: professores que lecionavam no ensino fundamental ( $5^{\mathrm{a}}$ a $8^{\mathrm{a}}$ séries) das escolas selecionadas e professores que tinham em algum momento do seu trabalho desenvolvido atividades relacionadas com EA, independentemente da disciplina. As entrevistadas foram realizadas no decorrer do ano letivo de 2006, sendo que a primeira entrevista ocorreu no dia 23 de março e a última no dia nove de novembro desse ano.

\subsubsection{Método de análise e interpretação dos dados}

Para a realização dessa etapa, as entrevistas foram transcritas literalmente e somente após ler e reler as transcrições exaustivamente e chegar a uma espécie de "impregnação dos conteúdos" (MICHELAT apud LÜDKE; ANDRÉ, 1986) foi possível elaborar os núcleos temáticos de interpretação que, posteriormente, formaram as categorias de análise.

Assim, para análise e interpretação dos dados optamos por utilizar a análise de conteúdos, "uma técnica de redução de um grande volume de material num conjunto de categorias de conteúdo", sendo que todo material coletado "examinado e toda a informação nele contida (...) fragmentada em termos de ocorrência de conteúdos ou categorias" (ANDRÉ, 1983, p. 67). A categorização, segundo Bardin (1991), “é uma operação de classificação de elementos constitutivos 
de um conjunto, por diferenciação e, seguidamente, por reagrupamento segundo o gênero (analogia), com critérios previamente definidos" (p. 17).

Numa discussão em torno de critérios para determinar o grau de importância de um tema ou tópico para transformá-lo em categoria, André (1983) avalia:

Acredito que a subjetividade e intuição têm um papel fundamental no processo de localização desse tipo de dado, além evidentemente do quadro teórico no qual o estudo se situa. Cada pesquisador tem perspectivas, propósitos, experiências anteriores, valores e maneiras de ver a realidade e o mundo que, ao interagirem com o objeto pesquisado, orientam o seu foco de atenção para problemas específicos, mensagens determinadas, aspectos particulares. Se pois por um lado devem existir métodos para tratar dados qualitativos, por outros lado é necessário o reconhecimento do papel da intuição e da subjetividade no processo de selecionar, categorizar e interpretar a informação (ANDRÉ, 1983, p. 68).

Ainda em relação à categorização, Lüdke e André (1986) alertam que ela por si só não esgota a análise dos resultados. Para esses autores a análise dos dados requer um cuidado que permita ao pesquisador aprofundar-se na sua interpretação:

É preciso que o pesquisador vá além, ultrapasse a mera descrição, buscando realmente acrescentar algo à discussão já existente sobre o assunto focalizado. Para isso ele terá que fazer um esforço de abstração, ultrapassando os dados, tentando estabelecer conexões e relações que possibilitem a proposição de novas explicações e interpretações. É preciso dar o "salto", como se diz vulgarmente, acrescentar algo ai já conhecido. Esse acréscimo pode significar desde um conjunto de proposições bem concatenadas e relacionadas que configuram uma nova perspectiva teórica até o simples levantamento de novas questões e questionamentos que precisarão ser mais sistematicamente exploradas em estudos futuros (LÜDKE; ANDRÉ, 1986, p. 49).

Desta maneira, valendo-se do referencial teórico apresentado no capítulo I, procuramos agrupar e identificar nas falas dos entrevistados elementos e dimensões que caracterizam a maneira como a EA vem sendo incorporada na educação formal, sendo, portanto, analisados o perfil dos professores, suas motivações em desenvolver atividades com a questão ambiental, os meio pelos quais se mantêm informados em relação à EA, as concepções de EA, as atividades desenvolvidas, os recursos utilizados e as dificuldades existentes nos trabalhos com EA. 


\subsection{O cenário da pesquisa}

\subsubsection{Sobre Piracicaba}

A história de cidade de Piracicaba, contada de maneira breve, começa em 1767, inicialmente como um povoado na foz do rio Piracicaba, que servia de apoio às embarcações que desciam em direção ao rio Tiête. A fertilidade da terra atraiu muitos fazendeiros e o povoado prosperou e foi elevado à categoria de vila em 1821, com o nome de Vila Nova da Constituição. Após um longo período de expansão de sua agricultura e pecuária, a antiga vila passou a ser um respeitado centro abastecedor e, em 1856, firmou-se como município. Porém, somente em 1877, por petição do então Vereador e mais tarde Presidente da República Prudente de Moraes, que a cidade passa a ser chamada oficialmente de Piracicaba, cujo significado, em Tupi-guarani, é "lugar onde o peixe pára" 10 .

O município de Piracicaba conta atualmente com 366.442 habitantes (IBGE, 2006) e situase em um importante pólo regional de desenvolvimento industrial e agrícola do interior do Estado de São Paulo, região que concentra uma população aproximada de 1,2 milhões de habitantes. O complexo industrial da região de Piracicaba é formado por mais de cinco mil indústrias, destacandose entre as variadas atividades os setores metalúrgicos, mecânico, têxtil, alimentício e petroquímico. No setor agrícola, destacam-se as culturas da cana-de-açúcar (10 milhões de toneladas/ano), do café (um milhão de pés), laranja (6 milhões de pés).

$\mathrm{Na}$ área educacional, a cidade conta com instituições de ensino superiores reconhecidas nacional e internacionalmente: a Escola Superior de Agricultura "Luiz de Queiroz" (Esalq/USP), o Centro de Energia Nuclear na Agricultura (CENA), a Universidade Metodista de Piracicaba (Unimep), Faculdade de Odontologia de Piracicaba (FOP / Unicamp) e a Escola de Engenharia de Piracicaba - Fundação Municipal de Ensino (EEP), totalizando 14.924 alunos matriculados em 2004 (IBGE, 2006).

As 156 escolas de ensino fundamental e médio da cidade contam, no ano de 2005, com 67.575 alunos matriculados (IBGE, 2006). Desses, 52.135 eram alunos do ensino fundamental (de todos os seus ciclos) e 15.440 alunos do ensino médio. Entre os alunos de ensino fundamental temos,

${ }^{10}$ As informações sobre o município de Piracicaba foram retiradas dos sites http://www.ciagri.usp.br/piracica/pirap.htm e http://www.ibge.gov.br/home/. 
32.344 são alunos da rede pública estadual, 11.462 são de escolas públicas municipais e 8.329 são alunos da rede privada de ensino. Entre os docentes que trabalham na cidade temos, em todos os ciclos da educação básica, 3.641 professores, sendo que 2.504 são professores do ensino fundamental - 1.534 pertencentes à rede estadual, 432 professores da rede municipal de ensino e 538 a rede privada de ensino.

\subsubsection{As escolas selecionadas para a pesquisa}

A amostragem na pesquisa qualitativa é outra questão debatida. Como não há preocupação em quantificar seus dados, a representatividade não é medida numericamente, sendo uma amostragem adequada "aquela que possibilita abranger a totalidade do problema investigado em suas múltiplas dimensões” (MINAYO, 1992 apud DESLANDES, 2003, p. 43). Goldenberg (2000) completa:

Partindo do princípio de que o ato de compreender está ligado ao universo existencial humano, as abordagens qualitativas não se preocupam em fixar leis para se produzir generalizações. Os dados da pesquisa qualitativa objetam uma compreensão profunda de certos fenômenos sociais apoiados no pressuposto da maior relevância do aspecto subjetivo da ação social. Contrapõem-se, assim, à incapacidade da estatística de dar conta dos fenômenos complexos e da singularidade dos fenômenos que não podem ser identificados através de questionários padronizados. Enquanto os métodos quantitativos supõem uma população de objetos comparáveis, os métodos qualitativos enfatizam as particularidades de um fenômeno em termos de seu significado para o grupo pesquisado (GOLDENBERG, 2000, p. 49-50).

$\mathrm{Na}$ presente pesquisa, optamos em trabalhar com uma amostragem que fosse ao mesmo tempo representativa e proporcional das escolas de ensino fundamental do município de Piracicaba. Para tanto, dividimos a cidade em quatro grandes áreas seguindo um padrão geográfico: centro, bairros centrais, bairros periféricos e zona rural e distrito. Em cada uma dessas regiões foram selecionadas através de sorteio um sexto das escolas estaduais e um terço das escolas particulares. Assim, das cinqüenta e quatro escolas estaduais e vinte escolas particulares existentes no município 
de Piracicaba e que foram selecionadas para participar da pesquisa, onze escolas pertencem à rede estadual e seis escolas da rede privada de ensino (Figura 4) ${ }^{11}$.

Dentre as escolas estaduais sorteadas para participar da pesquisa, duas foram substituídas, uma pela dificuldade de se estabelecer contato com a sua coordenação (mais de três tentativas de contato foram feitas com cada escola) e outra porque seus professores não se dispuseram a participar da pesquisa. Em contato por telefone com as coordenadoras, verificamos a existência de trabalhos com EA, contudo não foi possível obter informações mais detalhadas. Entre as escolas particulares, cinco escolas não concordaram em participar da pesquisa, sendo, portanto, substituídas. Essas escolas alegaram falta de tempo dos coordenadores e professores, incompatibilidade com a política da instituição ou, simplesmente, porque não conseguimos estabelecer contato (novamente para esses casos mais de três tentativas foram feitas). Não foi possível nesses casos verificar a existência de trabalhos com EA.

\footnotetext{
${ }^{11}$ A lista com os nomes das escolas de ensino fundamental das redes estadual e privada foi fornecida pela Diretoria Regional de Ensino de Piracicaba em 2005.
} 


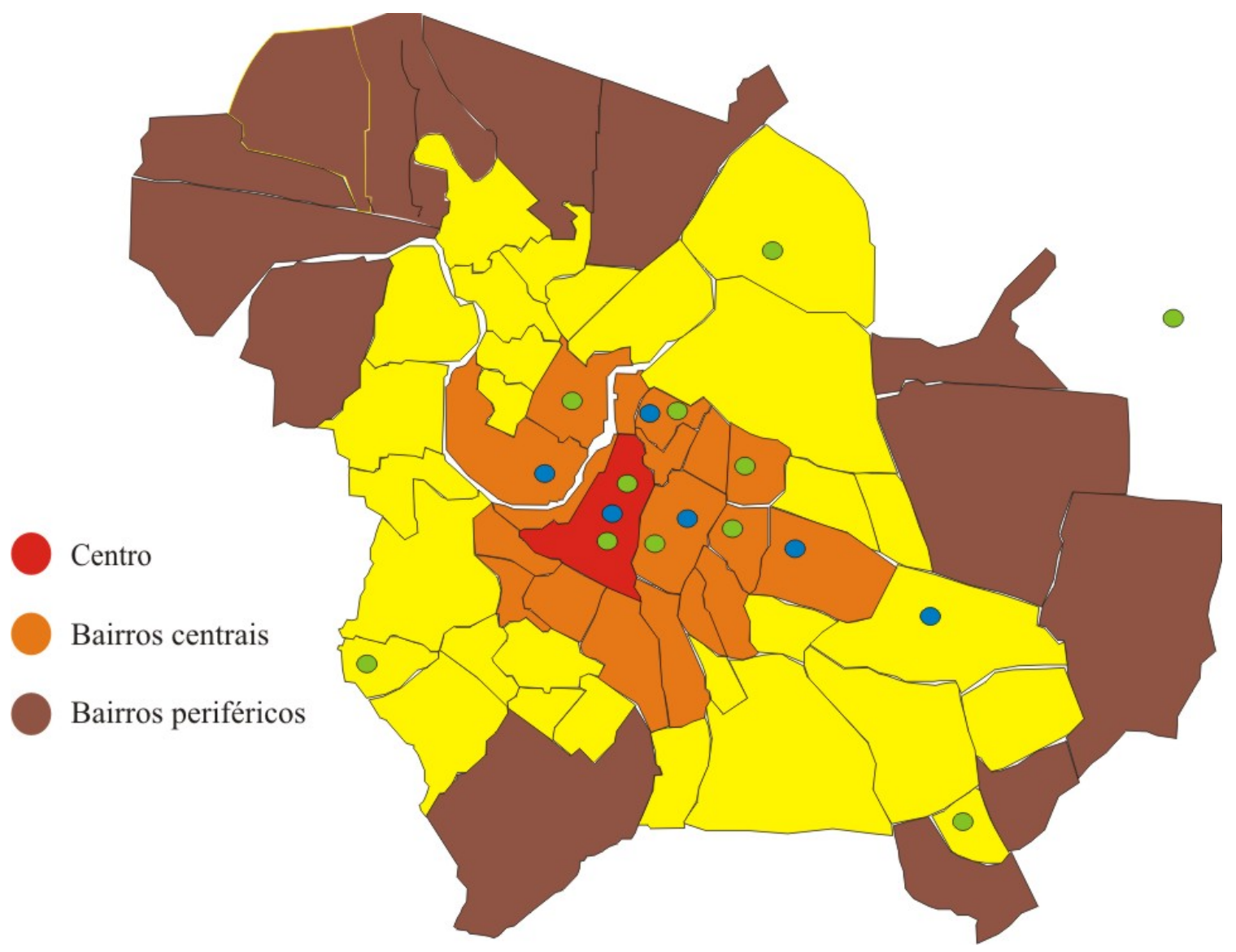

Figura 4 - Mapa do município de Piracicaba dividido em regiões geográficas

Os pontos azuis representam as escolas particulares selecionadas e os pontos verdes as escolas estaduais. A região geográfica referente à zona rural e distritos não está representada no mapa

Das quarenta e duas entrevistas realizadas, uma foi feita com uma diretora, onze com coordenadoras e trinta com professores do ensino fundamental, de $5^{\mathrm{a}}$ a $8^{\mathrm{a}}$ séries. Uma das entrevistadas era uma professora de Geografia e coordenadora da área de biologia na mesma escola particular em que foi entrevistada. Uma das professoras de Ciências de uma escola particular era também coordenadora de uma escola estadual selecionada para a pesquisa. Dois professores de Ciências de escolas estaduais também ensinam Matemática em suas escolas. Dois professores, um de Matemática e outro de Geografia, também trabalham em outras escolas selecionadas para essa pesquisa. Duas professoras de escolas estaduais, uma de História e outra de Português, foram indicadas por seus colegas para serem entrevistadas. Porém, ambas alegaram não desenvolver 
qualquer atividades de EA. Dos onze coordenadores, três são de escolas particulares e oito da rede estadual de ensino. A única diretora entrevistada estava ligada à rede particular de ensino. Dentre os trinta professores entrevistados, oito foram entrevistados nas escolas particulares e vinte e dois pertencem às escolas estaduais selecionadas para a pesquisa (Figura 5).

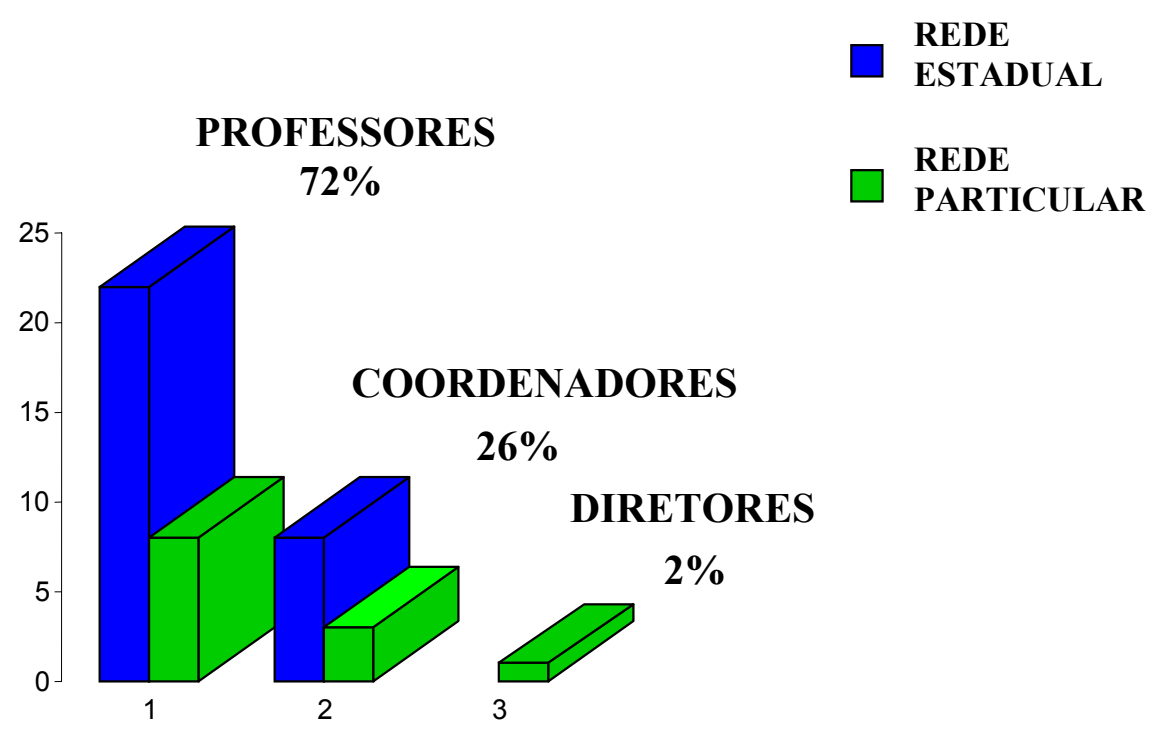

Figura 5 - Porcentagem entre diretores, coordenadores e professores entrevistados para pesquisa

Pudemos notar diferenças de comportamentos durante as entrevistas realizadas com os professores e coordenadores. Os professores mostraram-se muito mais críticos em relação à sua prática pedagógica e incorporação da EA pela escola dos que os coordenadores e diretora entrevistados. Esse quadro ficou muito evidente numa das últimas entrevistas realizadas. A entrevistada era professora em uma escola particular e coordenadora em uma escola estadual. Quando se referia às suas atividades enquanto professora, mostrava-se muito mais sensível e crítica em relação à realidade e às adversidades que a EA encontra ao ser inserida nas práticas de ensino do que quando ela se colocava como coordenadora. 


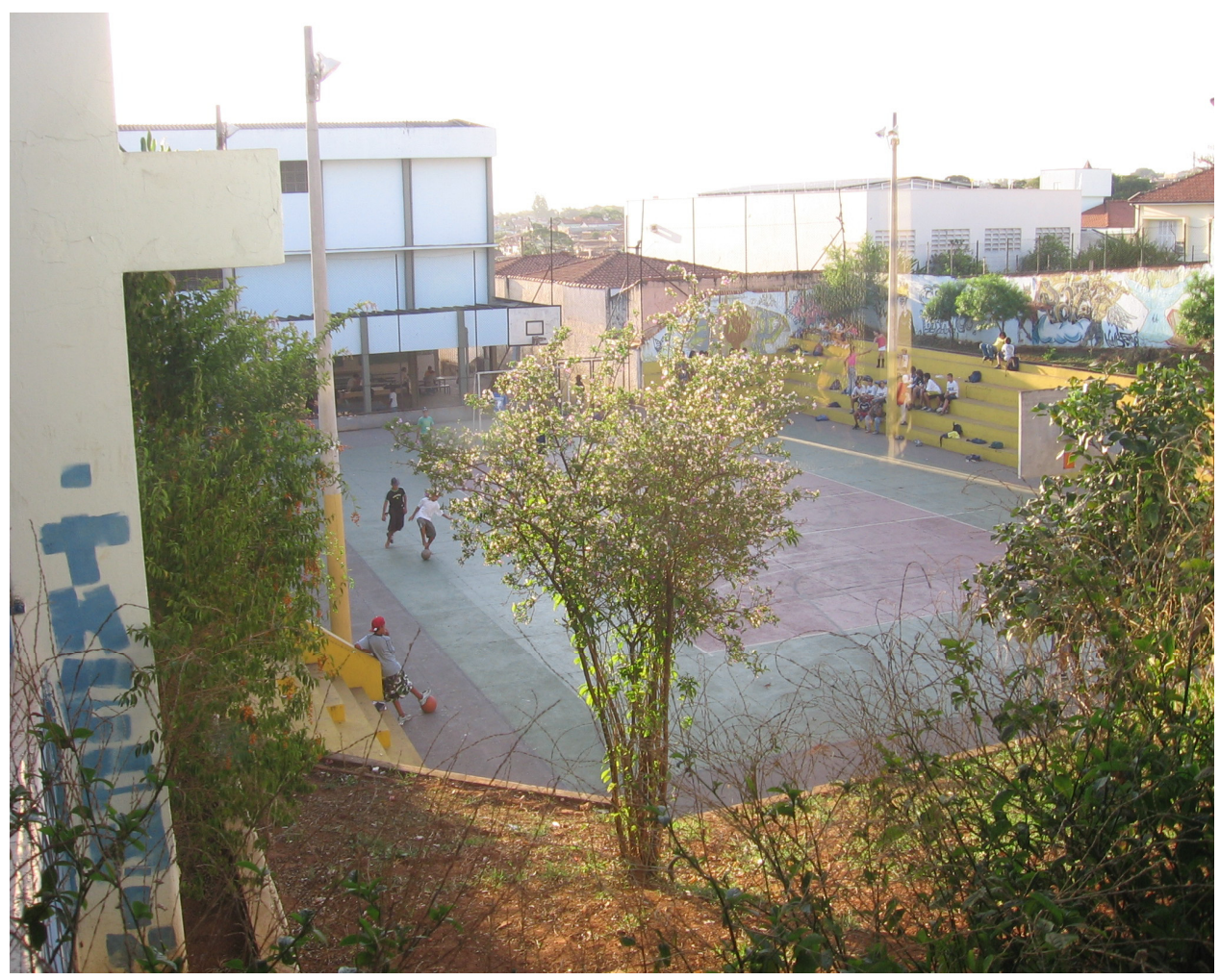

Figura 6 - Pátio interno de uma escola estadual

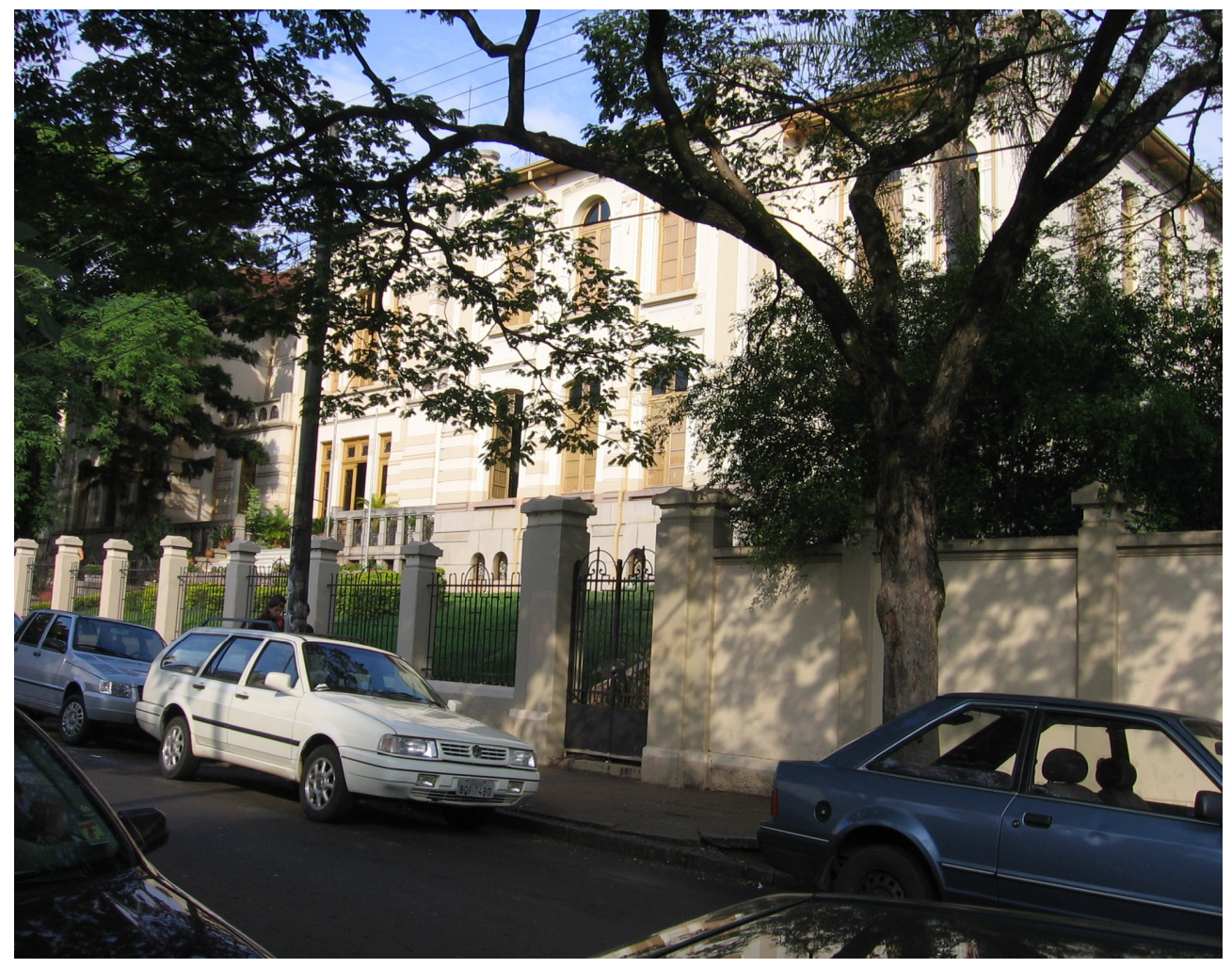

Figura 7 - Fachada externa de uma escola estadual 
No intuito de preservar a identidade dos entrevistados, eles foram identificados pela função que desempenham na escola (diretor, coordenador ou professor), pela disciplina que lecionam, no caso dos professores, e pela escola que pertencem, sendo indicadas por letras e diferenciadas em relação à rede estadual ou privada de ensino.

Para efeito da interpretação e discussão dos dados não foram considerados nem o tamanho ou a localidade das escolas como um parâmetro de análise, sendo as escolas diferenciadas apenas entre particular ou estadual. 


\section{RESULTADOS E DISCUSSÃO}

(...) com que instrumentos trabalha o educador? Com a palavra. $O$ educador fala. Mesmo quando o seu trabalho inclui as mãos, como o mestre que ensina o aprendiz a moldar a argila, ou o cientista que ensina o estudante a manejar o microscópio, todos os seus gestos são acompanhados de palavras. São palavras que orientam as mãos e os olhos.

Rubem Alves

O presente capítulo tratará da análise dos resultados obtidos das entrevistas com professores, coordenadores e diretora das escolas selecionadas para participar da pesquisa. Para tanto, dividimo-lo em três partes: a primeira parte - Os professores que trabalham com Educação Ambiental - irá caracterizar os professores entrevistados em relação ao sexo, idade, tempo de magistério e permanência na escola em que foram entrevistados, e formação acadêmica. Além disso, abordaremos os incentivos que os professores têm para desenvolver trabalhos com EA e as maneiras pelas quais a discussão da problemática ambiental tem chegado aos professores, no que se refere aos meios pelos quais eles se mantêm informados em relação à EA e também à formação em EA dos entrevistados. A segunda parte - As concepções de Educação Ambiental dos professores entrevistados: tendências reveladas - discutirá as tendências de EA reveladas nessa pesquisa a partir das respostas dos professores, coordenadores e diretora em relação aos seus entendimentos sobre educação, meio ambiente, desenvolvimento sustentável e EA. E, finalmente, a terceira parte desse capítulo - A incorporação da Educação Ambiental na escola de ensino fundamental tratará das maneiras como as escolas de ensino fundamental de Piracicaba têm incorporado a EA no currículo, através do levantamento das atividades, dos conteúdos, dos recursos utilizados, da maneira como trabalham os professores de diferentes disciplinas aqui representadas e das dificuldades encontradas nos trabalhos de EA apontadas pelos entrevistados. Em todos esses momentos, haverá a análise, interpretação e discussão dos dados coletados a partir da bibliografia levantada e discussões sobre o tema. 


\subsection{Os professores que trabalham com Educação Ambiental}

Nessa primeira parte iremos caracterizar os professores que trabalham com EA nas escolas de ensino fundamental de Piracicaba. Quem é esse professor que aborda a problemática ambiental em suas aulas? Quais são suas motivações? De que maneira mantém-se informado em relação à EA? Quais são os cursos relacionados à EA que chegam a esses professores? A opção pelo levantamento do perfil do professor se dá por entendermos que são eles que efetivamente colocam-se na linha de frente das práticas de EA no ensino formal, sendo, portanto, os protagonistas das transformações curriculares (MEDINA, 1999) e da incorporação da EA dentro da escola. Por isso, nada mais importante do que conhecê-lo. Assim, iremos, primeiramente, configurá-los em relação à idade, sexo, disciplinas que lecionam, tempo de magistério, permanência na escola em que foram entrevistados e formação acadêmica. Também discutiremos os motivos que levam esses professores a trabalharem com EA e as maneiras pelas quais eles se mantêm informados em relação às questões ambientais. Finalizaremos com o levantamento dos cursos de EA citados pelos entrevistados.

\subsubsection{A caracterização dos professores}

Das dezessete escolas selecionadas para a pesquisa, entrevistamos um total de trinta professores, sendo que vinte e dois $(73 \%)$ deles pertencem à rede estadual e oito $(27 \%)$ à rede privada de ensino (Figura 8).

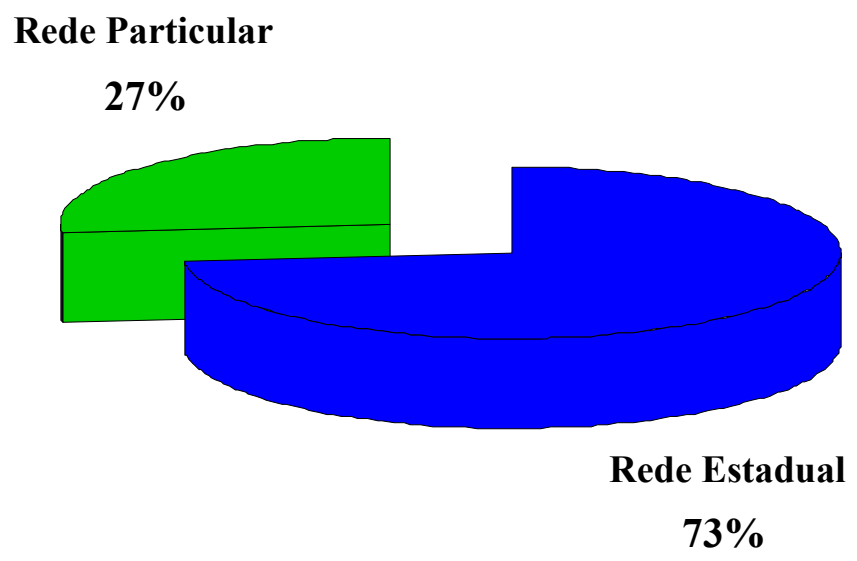

Figura 8 - Porcentagem de professores pertencentes as rede estadual e privada de ensino 
O grupo formado pelos professores entrevistados é constituído por maioria feminina, sendo que vinte e três $(73 \%)$ dos professores entrevistados são mulheres e apenas sete $(27 \%)$ são homens (Figura 9).

\section{Homens}

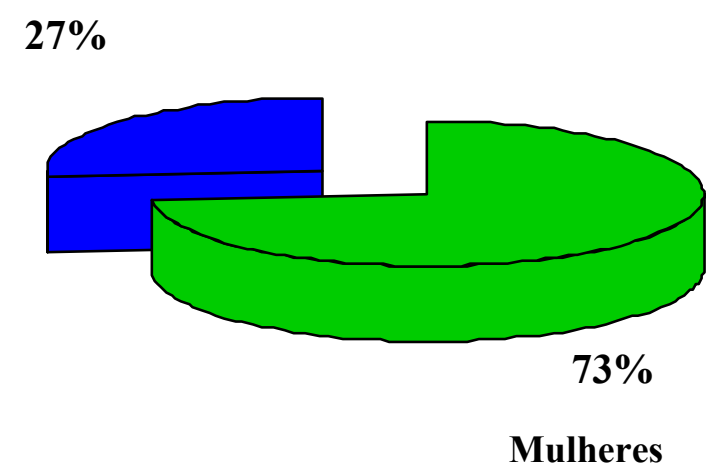

Figura 9 - Porcentagem de mulheres e homens participantes da pesquisa

Quanto à faixa etária dos participantes da pesquisa temos um grupo bastante heterogêneo, com idades que variam dos 23 aos 57 anos, sendo a média aproximada de 37 anos (Figura 10). Observamos um número maior de professores na faixa etária que vai dos 41 aos 45 anos, com sete (23\%) professores. Em seguida, temos as faixas etárias que vão dos 31 aos 35 anos, com seis (20\%) professores; dos 26 aos 30 anos, com cinco (17\%) professores; e a dos 36 aos 40 anos, com quatro (13\%) professores. Os entrevistados mais jovens, com idades que variam dos 20 aos 25 anos, estão representados por três $(10 \%)$ professores. Os professores mais velhos estão nas faixas etárias dos 46 aos 50 anos e, dos 51 aos 55 anos, temos dois (7\%) professores cada e, finalmente, apenas um (3\%) professor na faixa dos 56 aos 60 anos. 


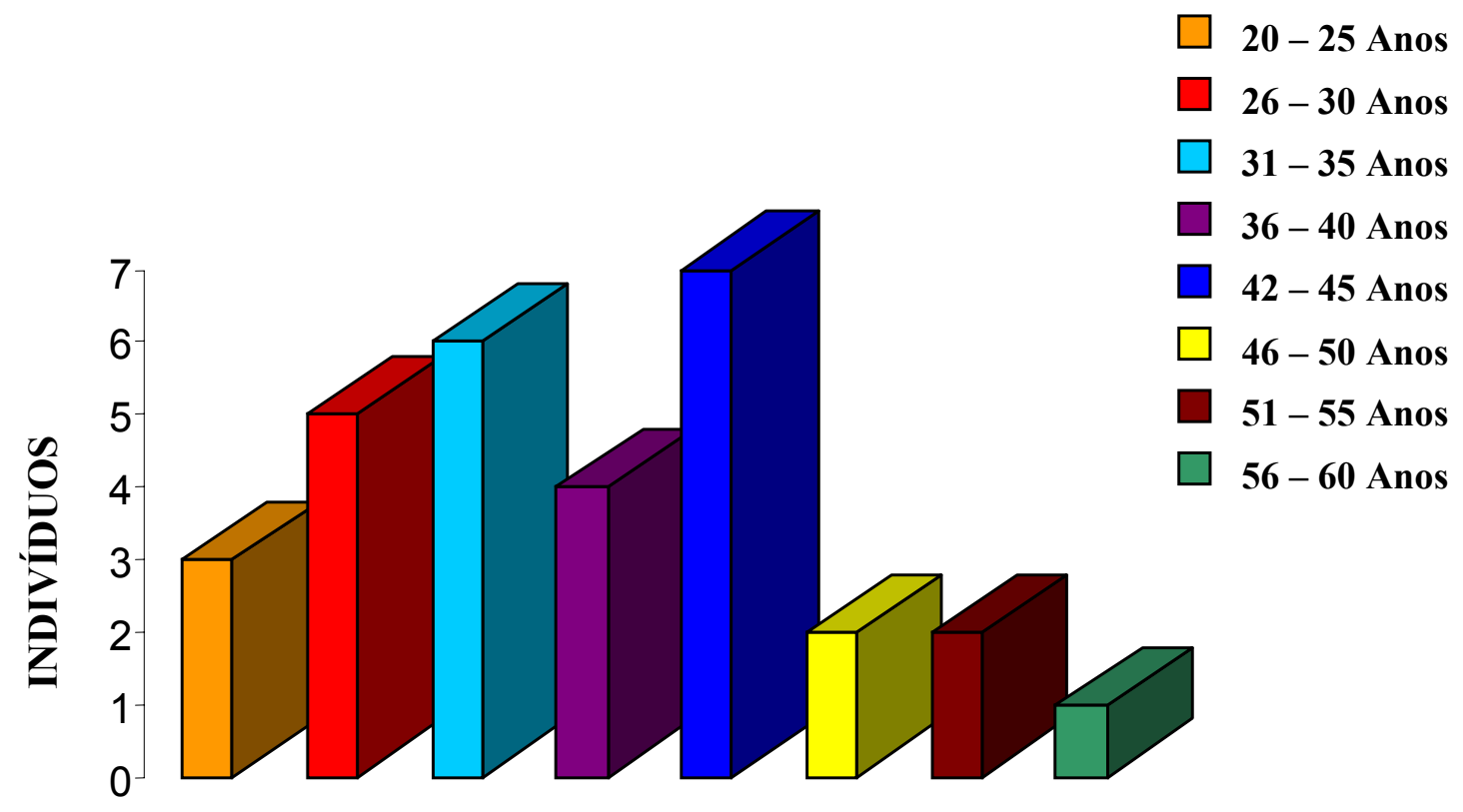

FAIXAS ETÁRIAS

Figura 10 - Distribuição etária dos participantes da pesquisa

Em relação à formação acadêmica dos professores entrevistados verificamos que quinze deles concluíram o ensino superior em instituições privadas e catorze concluíram em intuições públicas de ensino. Para um professor essa pergunta não foi feita (Tabela 1). Dentre as Instituições de Ensino Superior (IES) citadas pelos professores temos Faculdade de Americana (FAM), Faculdade de Oswaldo Cruz, Universidade do Estado de São Paulo (UNIESP) - campus Presidente Prudente, Faculdade de Tatuí, Unesp - campus Bauru e Rio Claro, Universidade Estadual de Campinas (Unicamp), Universidade de Santo Amaro (UNISA), Universidade de São Paulo (USP) campus Ribeirão Preto, São Paulo e Piracicaba (“Escola Superior de Agricultura Luiz de Queiroz” Esalq), Universidade Estadual de Montes Claros (Unimontes) e Universidade Metodista de Piracicaba (Unimep). Entre essas, destacamos a Unimep, com nove (31\%) professores, a Unesp Rio Claro, com oito (28\%) professores e a Esalq, com apenas uma (3\%) professora, todas sendo IES de Piracicaba ou da região.

Entre os professores entrevistados, temos seis (20\%) que concluíram ou estão para concluir algum curso de pós-graduação - três da rede particular e três da rede estadual. Desses, destacamos três que estão relacionados com a área de educação ou de EA. A professora de Artes da Escola Particular C fez pós-graduação lato sensu em psicopedagogia na Unicamp, a professora de Ciências 
da Escola Estadual E fez mestrado na Unesp - Bauru em Educação e Ciências e o professor de Geografia da Escola Estadual C está cursando pós-graduação lato sensu na Unicamp, numa área sobre a qual não temos muitos detalhes, embora saibamos que está relacionada a meio ambiente e cidadania.

Tabela 1 - Instituições de Ensino Superior cursada pelos professores entrevistados participantes da pesquisa e o número de vezes que foram citadas

\begin{tabular}{cccc}
\hline $\begin{array}{c}\text { Instituições de } \\
\text { Ensino Superior }\end{array}$ & $\begin{array}{c}\text { Rede } \\
\text { Particular }\end{array}$ & $\begin{array}{c}\text { Rede } \\
\text { Estadual }\end{array}$ & TOTAL \\
FAM & - & 1 & 1 \\
Faculdade de Oswaldo Cruz & - & 1 & 1 \\
UNIESP & - & 1 & 1 \\
Faculdade de Tatuí & - & 2 & 2 \\
Unisa & - & 1 & 1 \\
Unimep & 3 & 6 & 9 \\
Esalq & 1 & - & 1 \\
Unicamp & 1 & - & 1 \\
USP - Ribeirão Preto & - & 1 & 1 \\
USP - São Paulo & - & 1 & 1 \\
Unimontes & - & 1 & 1 \\
Unesp - Bauru & - & 1 & 1 \\
Unesp - Rio Claro & 3 & 5 & 8 \\
Não foi perguntado & - & 1 & 1 \\
\hline
\end{tabular}

Em relação ao tempo que os professores que participaram da pesquisa lecionam, novamente temos um grupo bastante variado, que vai desde um mês a trinta e dois anos de magistério (Figura 11). Sete (24\%) professores encontram-se na faixa de tempo de magistério de dezesseis a vinte anos, seguidos por seis (20\%) professores nas faixas de um a cinco anos, seis $(20 \%)$ a dez anos e seis (20\%) professores na faixa dos onze a quinze anos de magistério. Dois (7\%) professores estão na faixa de vinte e seis a trinta anos de magistério. Finalmente, temos um (3\%) 
professor entre vinte e um a vinte e cinco anos de magistério, um (3\%) professor entre trinta e um a trinta e cinco anos de magistério e uma (3\%) professora com menos de um ano de magistério.

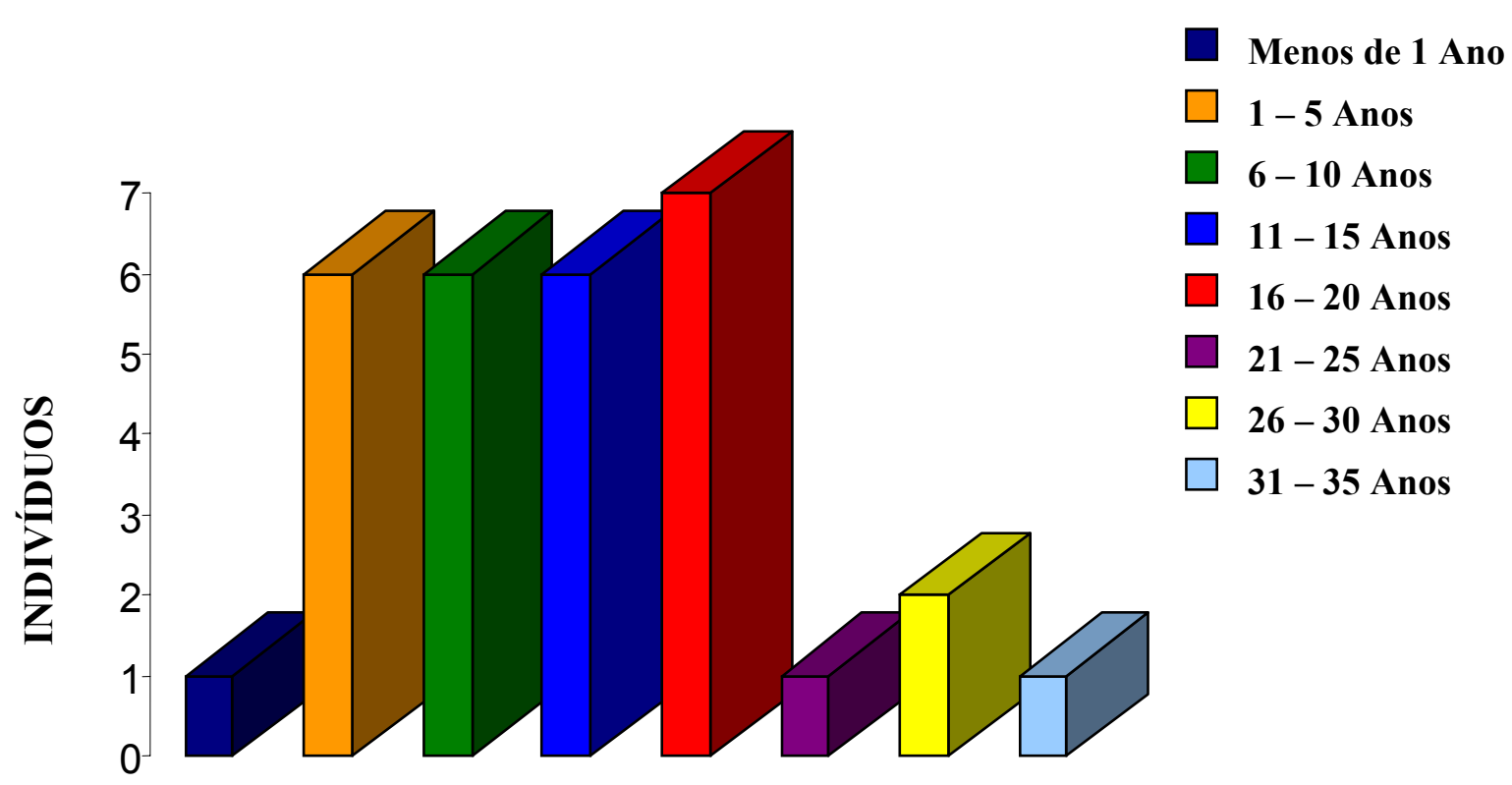

TEMPO DE MAGISTÉRIO

Figura 11 - Tempo de magistério dos professores envolvidos na pesquisa

Entre os professores entrevistados pudemos constatar que sete (23\%) têm até cinco anos de magistério. Dentre esses: quatro não desenvolvem projetos ou atividades de EA, só tratando os temas ambientais quando esses estão relacionados aos conteúdos programados das suas disciplinas. Para esses professores o excesso de projetos direcionados para suas áreas, a falta de oportunidade ou por serem iniciantes na carreira ou na escola em que trabalham são motivos que os impedem de desenvolverem trabalhos com EA. Por outro lado, constatamos que outras três professoras também com pouco tempo de docência desenvolvem projetos e/ou outras atividades extracurriculares de EA. Ao analisar a trajetória profissional dessas professoras observamos que duas delas tiveram experiências anteriores com EA (fora da escola em que hoje atuam) - uma professora desenvolveu trabalhos relacionados à EA durante sua graduação e pós-graduação e a outra professora trabalhou com EA na sua graduação e em estágio no núcleo ambiental de uma empresa da cidade. 
Verificamos, assim, que os professores entrevistados que declararam não realizar trabalhos extracurriculares com EA não freqüentaram qualquer tipo de capacitação ligada a essa temática após finalizaram sua graduação. Ao analisar a trajetória profissional dos professores entrevistados que possuem mais de seis anos de magistério e que desenvolvem atividades extracurriculares de EA, notamos que todos procuram se atualizar em relação a sua profissão e também em relação à EA, fazendo cursos de especialização, de capacitação, de pós-graduação e assistindo palestras e/ou simplesmente informando-se através da mídia ou outros meios.

Outros estudos relativos à incorporação da EA na educação escolar também encontraram uma dicotomia em relação à formação inicial e continuada dos professores (CARVALHO, 2005, 1989; GUERRA; GUIMARÃES, 2007; GUIMARÃES, 2003; LOUREIRO, 2003; MEDINA, 2001; SEGURA, 2001; TRITÃO, 2004). Martha Tristão (2004), em seu estudo da inserção da EA nas práticas educativas das escolas do município de Vitória/ES, se deparou com uma lacuna entre formação inicial e continuada dos professores. Para a ela, a formação básica e o magistério não podem ser momentos distintos para os professores, pois "fazem parte dos elos que compõem a tecitura da formação profissional". Para ela "aprender a ser professor/a é um processo que tem início e não fim", e "as licenciaturas não podem deixar o/a professor/a pronto/a, acabado/a. O curso isolado não atenderia às necessidades de uma prática em educação ambiental” (p. 144).

Por outro lado, devemos nos perguntar se as IES estão cumprindo seu papel na formação desses educadores. Para Loureiro (2003), as IES, em geral, não possuem políticas claras e definidas para a contemplação da EA nos seus cursos. O que existe, para o autor, são núcleos disciplinares ou multidisciplinares direcionados para essa temática que são desenvolvidos, na maioria das vezes, por iniciativa de alguns docentes, que "promovem a produção acadêmica, cursos de extensão, de especialização e linhas de pesquisa em programas de pós-graduação stricto sensu" (p.88). Carvalho (1989) também se mostra critico em relação ao papel que a Universidade está tendo na incorporação da EA ao ensino escolar, tanto no que se refere à formação inicial dos professores, nos cursos de licenciaturas, quanto à formação continuada desses profissionais:

A temática ambiental está presente em alguns cursos de licenciatura, mas, no geral, a abordagem dada ao tema restringe-se à área específica desse curso. Não existe uma interação entre as diferentes áreas do conhecimento de tal forma que essa postura se reflita no trabalho realizado com os alunos. Além disso, em muitos dos cursos, a problemática não recebe nenhum tratamento mais sistemático (CARVALHO, 1989, p. 250). 
De fato, em uma recente pesquisa-piloto de mapeamento da EA nas IES brasileiras, concluiu, entre outras coisas, que a maioria das universidades participantes da pesquisa (70\%) não tem órgãos que centralizem ou coordenam as ações de EA nas suas instituições (BRASIL, 2007a). Outra informação importante destacada no diagnóstico da EA no Brasil realizado por Carvalho (2005), e corroborada por aquela pesquisa, é a preferência por parte das IES em desenvolver projetos de intervenções sociais em detrimento do desenvolvimento de programas de políticas públicas. É exatamente a falta de políticas públicas, na opinião dos entrevistados da primeira pesquisa, que se constitui como um dos entraves para a inclusão da EA nas IES. Os projetos são ações de curto e médio prazos (ações pontuais), importantes dentro das IES pelo caráter inovador, mas precisam ser complementados por programas de políticas públicas, que são ações de longo prazo e dão alicerce estrutural sólido para a inclusão efetiva da EA nas Universidades (CARVALHO, 2005).

O estudo realizado por Carvalho (2005) também revelou que, em sua maioria, as instituições que fomentam a EA são públicas (escolas, universidades, órgãos governamentais), seguidas por organizações sociais e pelas instituições privadas. Assim, cabe à Universidade, principalmente a pública, sistematizar a problemática ambiental ao seu no currículo e, consequentemente, na formação inicial e continuada dos professores que atuam no ensino formal, o que auxiliará no desenvolvimento e incorporação da EA ao currículo escolar. Sabemos que a chegada tardia da EA à Universidade e as dificuldades que a mesma enfrenta para ser inserida nesse espaço constituem um grande obstáculo a ser superado (GUERRA e GUIMARÃES, 2007), mas é imprescindível que as IES introduzam a temática ambiental em seus currículos, pois têm, por excelência, "co-responsabilidades na formação de profisssionais e na produção científica" (GUERRA; GUIMARÃES, 2007, p. 159).

Outro levantamento feito pela presente pesquisa foi o tempo que cada professor leciona na escola em que foi entrevistado (Figura 12). Temos desde um mês a dezesseis anos de permanência na mesma escola. Os entrevistados, na sua maioria, encontram-se no primeiro ano de docência na escola em que foram entrevistados. Nessa situação, temos doze (40\%) professores, sendo que dois deles da rede particular e dez da rede estadual de ensino. Com um a cinco anos lecionando na mesma escola, temos sete $(23 \%)$ professores, sendo três professores de escolas particulares e quatro de escolas estaduais. De seis a dez anos temos seis (20\%) professores, dois de escolas particulares e quatro de escolas estaduais. De onze a quinze anos lecionando numa mesma escola, temos dois (7\%) professores, e de dezesseis a vinte anos, um (3\%) professor, todos da rede estadual de ensino. 


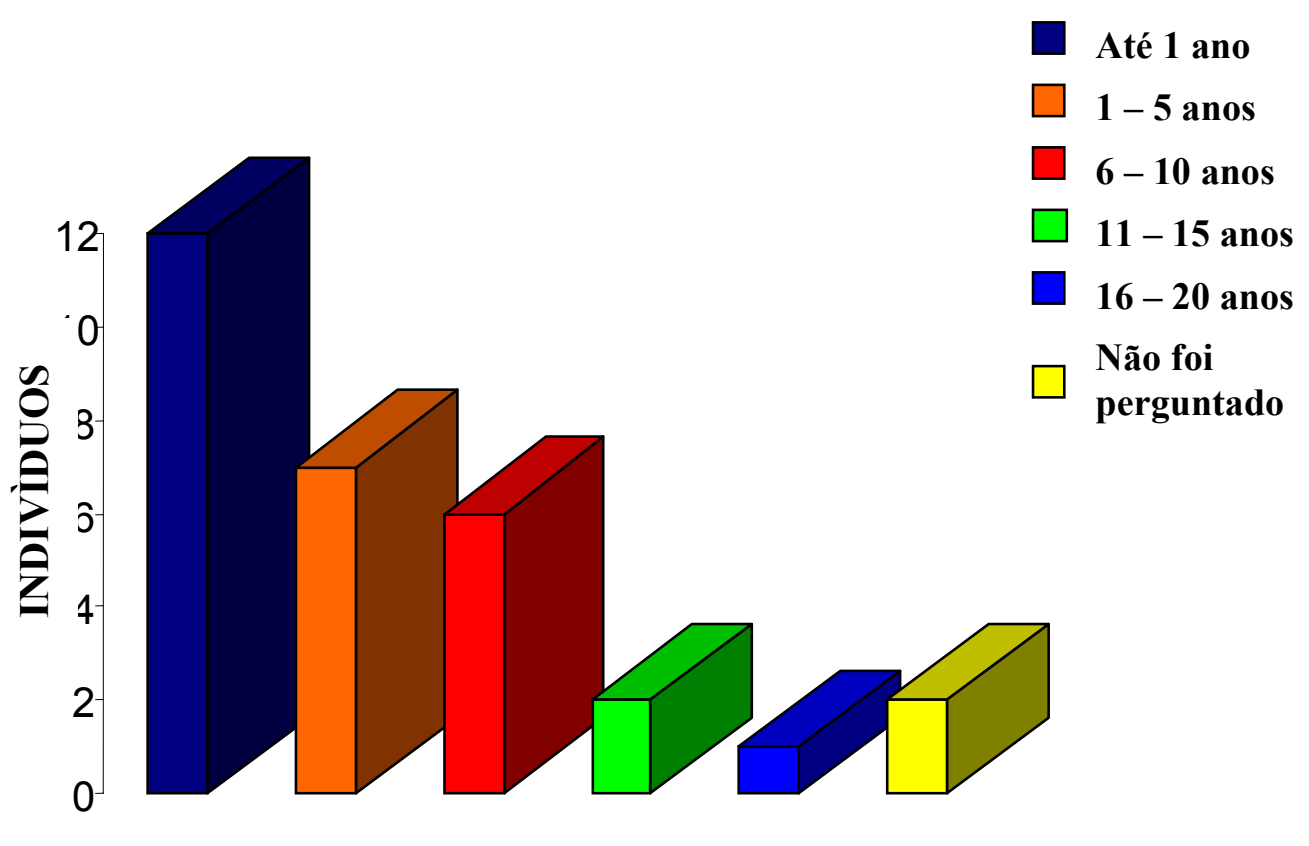

TEMPO DE PERMANÊNCIA

Figura 12 - Tempo de permanência dos professores nas escolas onde foram entrevistados

Uma nova ligação pode ser feita entre o tempo de trabalho na escola e o desenvolvimento de trabalhos com EA. Dos doze professores com no máximo um ano de trabalho na escola em que foram entrevistados, sete ainda estavam em fase de adaptação e no momento da pesquisa não desenvolviam atividade relacionada à EA (alguns desses estavam em fase de planejamento do projeto de EA). Outros cinco professores estavam trabalhando em projetos de EA e encontravam nos colegas e/ou direção da escola apoio na realização desses trabalhos. A rotatividade dos professores nas escolas, principalmente públicas, impõe-se assim como um problema não só no desenvolvimento de atividades de EA como também permeia toda a prática pedagógica da escola. Essa é umas das dificuldades para inserção da EA no ensino formal e voltaremos a ela no final deste capítulo.

Os professores entrevistados são responsáveis pelas disciplinas de Ciências, Geografia, Matemática, Artes e Português (Figura 13). A disciplina de Ciências foi representada por quatro professores de escolas particulares e catorze professores de escolas estaduais, somando dezoito $(60 \%)$ professores. Três professores de escolas particulares e quatro professores de escolas estaduais que lecionam Geografia participaram da pesquisa, totalizando de sete (23\%) professores. Uma 
professora da rede particular e uma da rede estadual de Educação Artística foram entrevistadas, totalizando duas (7\%) professoras. E finalmente, entrevistamos dois (7\%) professores de Matemática e uma (3\%) professora de Português, todos da rede de ensino estadual.

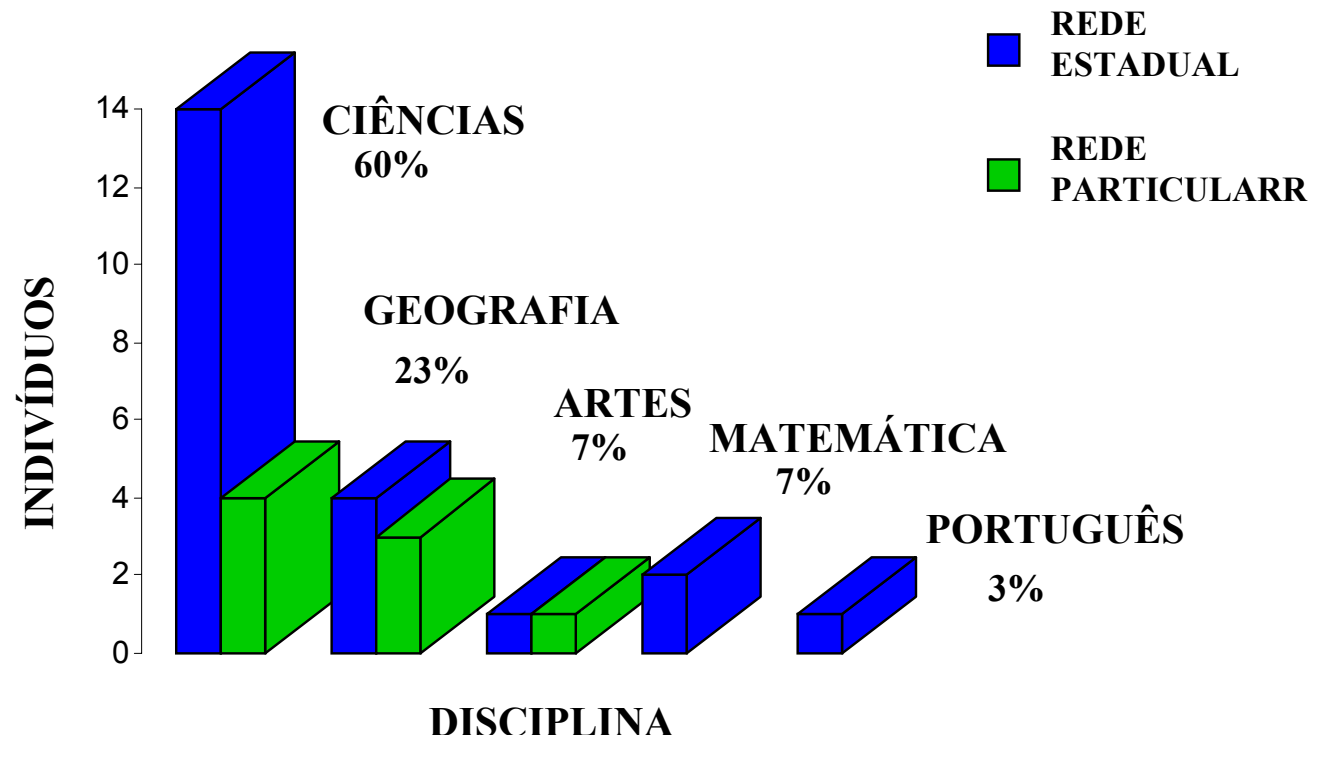

Figura 13 - Disciplinas que os professores entrevistados lecionam (total em porcentagem)

Vale ressaltar que em todas as escolas visitadas era solicitado aos coordenadores ou diretores para indicar entre o corpo docente da sua escola os professores de ensino fundamental que desenvolviam trabalhos relacionados com EA. Assim, chama a atenção o número elevado de professores de Ciências (18) seguidos pelos professores de Geografia (7) que participaram da pesquisa. As disciplinas de Artes, Matemática e Português somam cinco (15\%) professores do total de entrevistados. Muitos dos professores de Ciências e Geografia entrevistados só tratam de temas ligados a EA dentro dos conteúdos programados da suas disciplinas, não desenvolvendo outras atividades ou projetos paralelos.

Essa proporção desigual entre as disciplinas que participaram dessa pesquisa nos permite levantar, mesmo que nesse momento de maneira breve, algumas considerações preliminares a respeito da inserção da EA no ensino formal. Primeiramente, esse fato pode refletir uma tendência de que a EA está sendo desenvolvida como uma parte integrante do conteúdo de ensino das disciplinas de Ciências e Geografia, em especial essa primeira. Uma segunda observação, que é 
conseqüência da primeira, é o caráter conservador que revela ter a EA no contexto escolar. Essa será uma discussão que percorrerá todo terceiro capítulo deste trabalho e que pretendemos nos aprofundar. Por ora, fica a questão: as disciplinas de Ciências e Geografia, sozinhas, conseguem tratar as dimensões sociais e políticas tão pertinentes à discussão da problemática ambiental ou restringem-se aos aspectos biológicos e físicos do tema?

\subsubsection{A motivação dos professores para trabalhar com Educação Ambiental}

Fez parte dos objetivos da presente pesquisa investigar quais são os incentivos que levam os professores a trabalhar com EA. Para tanto, durante as entrevistas foi perguntado aos professores como iniciaram seus trabalhos com EA e/ou quais foram os motivos que os levaram a trabalhar com EA.

A partir das falas dos professores, foi possível dividi-los em dois grupos. O primeiro grupo elegeu incentivos externos, que independem das suas motivações pessoais ou mesmo incentivos da escola que trabalham, para iniciarem seus trabalhos com EA. Nesse grupo temos professores que trabalham com EA porque existe uma forte pressão dos órgãos governamentais de educação, estaduais e federais, para que a escola desenvolva projetos com EA. Temos também aqueles professores que acabam inserindo temáticas ambientais pelas facilidades e atrativos oferecidos pelas instituições parceiras das escolas no desenvolvimento de projetos, como, por exemplo, materiais didáticos, capacitações, premiações aos alunos e/ou escola ou a possibilidade de serem realizadas excursões.

Deparamo-nos também com professores que iniciaram o trabalho com EA por motivos que vão além e independem do caráter legislativo obrigatório da EA ou as facilidades que apresentam as empresas parceiras da escola. São professores preocupados com as causas ambientais, sendo, portanto, esse o principal incentivo para realizarem trabalhos com EA. A professora de Ciências da Escola Estadual E representa bem na sua fala esse segundo grupo:

"Acho que o incentivo é meu mesmo. Por eu ter uma formação nesta área, por princípios meus (...) Porque é assim, os colegas não ajudam. A direção da escola às vezes nem sabe que a gente está desenvolvendo projeto. (...) Ás vezes você está trabalhando e alguns colegas não entendem o que é...”. 
Esses professores incorporaram os temas ambientais nas suas práticas pedagógicas por sentirem ser essa uma emergência do contexto atual, como uma "necessidade que os tempos atuais nos colocam" (professor de Geografia da Escola Estadual F). A motivação, assim, nasce de uma percepção pessoal da necessidade de mudanças que o momento atual exige:

"Porque é uma necessidade do mundo. O que eu mais falo para eles quando eu cito alguma coisa sobre o ambiente é que todo mundo sabe tudo. O que pode, o que não pode, o que se faz. Mas ninguém vai lá e aplica. (...) Eles sabem o que é, mas ninguém tem a ação correta". (professora de Ciências da Escola Particular B)

Para outros professores, o despertar para a problemática ambiental ocorreu durante a formação acadêmica. Notamos que esses professores tiveram uma vivência estudantil diferenciada daqueles que simplesmente parecem ter passado pela universidade. A professora de Ciências da Escola Particular C, que ainda cursa a graduação na Esalq, acredita que sua formação acadêmica foi se direcionando para esse lado ambiental "(...) foi uma parte que eu me interessei”, e esse interesse pessoal foi sendo incorporado pouco a pouco nas suas práticas pedagógicas. Nesse grupo de professores que apontam o curso de graduação como o início de seu interesse para as questões ambientais, vale destacar aqueles que freqüentaram a Unesp de Rio Claro. A presença do curso de ecologia pode explicar essa forte influência, como observamos na fala da professora de Ciências da Escola Estadual G:

"Na verdade eu sempre trabalhei porque eu tive uma área muito forte na faculdade de ecologia. Como em Rio Claro eles tinham uma faculdade de ecologia, a gente trabalhava muito junto (...). Então, isto sempre chamou minha atenção".

É também no resgate do histórico de vida de alguns entrevistados que as dimensões pessoais ganham um maior destaque como motivações que levam esses professores a desenvolver trabalhos com EA, muitas vezes buscando uma realização pessoal e profissional, pois "não existe dinheiro no mundo que pague uma realização pessoal" (professor de Ciências e Matemática da Escola Estadual A e H). As análises das falas desses professores nos trazem revelações importantes, como a do professor de Ciências e Matemática das Escolas Estaduais A e H:

"Eu fui técnico de segurança de trabalho. Fui bombeiro e depois gosto muito da natureza. Eu ouvia falar muito de projeto ambiental e já fazia... Sempre fiz 
projetos como voluntário. Ai fui pegando gosto pela coisa e hoje aplicamos aqui na escola e está dando resultado”.

Esse professor também participou da Conferência das Nações Unidas sobre Meio Ambiente e Desenvolvimento (Eco-92) como palestrante:

"Na época da Eco-92 as usinas eram já obrigadas a instalarem equipamentos de proteção ambiental e eu fui, como era parte do meu trabalho, um dos responsáveis pela implantação do sistema. Aí, a partir de 92, eu fiz vários cursos. No Senai, no Sesi...".

Temos também aqueles que participaram do movimento estudantil e/ou do movimento ecológico e que levam essas experiências para dentro da sala de aula:

“(...) eu sempre estou participando (...) Quando fiz faculdade eu participava do movimento estudantil. (...) E esta parte ambiental na Unesp era bem presente no curso" (professora de Geografia da Escola Estadual C).

“(...) eu comecei a trabalhar especificamente foi em Florianópolis no ano 2000. Antes disso já era uma questão que me chamava a atenção, sempre me chamou a atenção. De alguma maneira sempre nas aulas de artes eu tentava falar... Claro que tenho um embasamento agora para falar, mas sempre tentei buscar. Efetivamente foi lá em Florianópolis que eu comecei a trabalhar porque eu fui convidada a trabalhar na oficina de artes e ambiente. (...). Desde então eu acho super dificil separar, eu não consigo mais não ser a ambientalista" (professora de Artes da Escola Particular C).

Dentro desse grupo, encontramos também uma professora que enxerga na EA e nas suas práticas pedagógicas a possibilidade de mudança que tanto necessita a escola pública. A fala da professora de Português da Escola Estadual K ilustra isso bem:

"E eu não vejo outra saída para a escola pública se não for a mudança. Então, eu acredito que nós estamos num periodo de transição. E é do caos que pode surgir o novo. Que a gente pode ainda recuperar a credibilidade da escola pública através de mudanças. E eu não vou dizer para você: ah, agora a escola vai mudar e só vai trabalhar com projetos. Não! (...) pelo menos o aluno tenha acesso a outro tipo de trabalho que não seja o conteúdo que é colocado para ele de uma forma repetitiva, cansativa e convencional. Não é nem o convencional do tradicional. É o que convêm para o professor". 
Realmente, a EA parece trazer um novo fôlego para o ensino da escola ao resgatar ou mesmo propor novas propostas de práticas de ensino, o que poderia resultar em uma melhoria na educação escolar. Buzzatti (1977 apud CARVALHO, 1989) acredita que a EA poderia formar um eixo norteador em que as estratégias de educação geral se orientariam. Essa é também uma proposta defendida por Medina (2001) ao apontar a EA como o eixo orientador em que os temas transversais trazidos nos PCNs poderiam entrar no currículo escolar, facilitando, assim, a sua inserção no ensino formal.

Portanto, um olhar mais atento na vivência desses professores nos revela momentos de suas vidas em que houve um despertar para a problemática ambiental, seja em um movimento estudantil, na universidade, em encontros de meio ambiente ou simplesmente por motivações do próprio momento de crise ambiental. Esses professores trazem essas experiências para suas práticas pedagógicas. Na segunda etapa da pesquisa diagnóstica da implementação da EA nas escolas brasileiras, realizada pelo MEC e Inep, tem-se que para 59\% das escolas pesquisadas as motivações iniciais para se trabalhar com EA são de um ou mais professores (BRASIL, 2007b). Em um trabalho recente, Carvalho (2002a) ${ }^{12}$ busca constituir e compreender o campo ecológico no Brasil tendo a trajetória de vida dos educadores ambientais como um dos seus parâmetros de estudo. Para a autora, ao contrário do sujeito-observador que se encontra fora do tempo histórico, o que existem são sujeitos-intérpretes que estão diante de um mundo-texto. De fato, mesmo que não seja nosso propósito nos aprofundarmos nessa questão, os professores por nós entrevistados encontram nas motivações pessoais os maiores incentivos e são exatamente esses os docentes que demonstram ter um maior engajamento nos trabalhos de EA, sendo muitas vezes os responsáveis por elaborar e liderar os projetos desenvolvidos nas escolas.

\subsubsection{Como a Educação Ambiental tem chegado aos professores}

Várias são as maneiras pelas quais os professores entrevistados disseram que se mantêm informados em relação à temática ambiental. Na tabela 2, temos reunidos os meios indicados pelos professores e a freqüência em que foram citados. Observamos que os veículos de comunicação são

\footnotetext{
12 Para maior aprofundamento ver CARVALHO, I.C.M. A invenção ecológica: narrativas e trajetórias da educação ambiental no Brasil. 2.ed. Porto Alegre: Editora da UFRGS, 2002.
} 
os mais citados pelos professores, sendo a Internet mais usada pelos entrevistados como um meio de se manterem informados, com quinze citações, e as revistas, com treze citações. Em seguida, temos a jornais (10) e televisão (9), livros (7), cursos/palestras (3) e diretores/coordenadores (3).

Em relação às citações referentes à televisão, alguns professores especificaram o canal, como Globo, Cultura, TV Escola e Futura e, outros, programas como Globo Repórter e Globo Ecologia. Entre as revistas, temos Nova Escola, Super Interessante, Veja, Galileu e revistas científicas, estas últimas sem maiores especificações. Quanto as referências a jornais, temos o Jornal de Piracicaba, o Estado de São Paulo e a Folha de São Paulo. Os livros mencionados são referentes aos didáticos ou aos específicos de EA.

Tabela 2 - Maneiras utilizadas pelos professores para se manterem informados em relação à Educação Ambiental e número de vezes que são citados, em ordem decrescente

Legenda: C - Ciências; G - Geografia; A - Artes; M - Matemática e P - Português

\begin{tabular}{ccccccc}
\hline $\begin{array}{c}\text { Meios pelos quais os } \\
\text { professores } \\
\text { informam-se }\end{array}$ & C & G & A & M & P & Total \\
\hline Internet & 9 & 5 & - & 1 & - & 15 \\
Revistas & 11 & 2 & - & - & - & 13 \\
Jornais & 8 & 1 & - & - & 1 & 10 \\
Televisão & 3 & 2 & 3 & 1 & - & 9 \\
Livros & 5 & - & 1 & - & 1 & 7 \\
Cursos /palestras & 2 & 1 & - & - & - & 3 \\
Diretor/coordenador & 2 & - & - & 1 & - & 3 \\
Não se informa sobre EA & - & 1 & 1 & - & - & 2 \\
\hline
\end{tabular}

A professora de Arte da Escola Estadual C e o professor de Geografia das Escolas Particulares B e E responderam que não se informam especificamente sobre EA. A professora de Artes tinha iniciado um projeto de EA com seus colegas e até então não se mantinha informada sobre o assunto. O professor de Geografia disse que se informa somente especificamente em relação a sua disciplina. Ele explica: 
"Eu me mantenho informado em relação à geografia. (...) Com os novos livros, que a gente recebe todo ano (...). Então, as novas edições eu procuro ler. Mas geralmente não tem muitas modificações".

Dentre os entrevistados, vinte declararam que se mantêm informados através de duas ou mais maneiras, seja através de revistas, jornais, televisão e/ou internet.

Alguns entrevistados declararam não terem tempo para acompanhar tantas informações e depois incorporá-las nas suas aulas. A professora de Ciências da Escola Estadual G demonstra na sua fala como a falta de tempo para pesquisar e o excesso de informações podem dificultar a busca de atualização do professor em relação aos temas ligados a EA:

"Através de leituras de revistas. Eu assino a revista Veja, a revista Galileu, revista de história... O problema é tempo para ler. E internet, quando tenho tempo. (...) A gente acaba ficando com excesso de trabalho e acaba ficando muito difícil de fazer tudo isto, mas eu me sinto na obrigação de estar lendo, de estar me informando"

Três professoras disseram que se mantêm informadas através das diretoras, coordenadoras e professores de suas escolas. Carvalho (1989), em sua pesquisa da temática ambiental nas escolas de ensino fundamental, também constatou a contribuição de outras pessoas da escola como um meio de informação para o professor. Esse autor vê essa possibilidade como um recurso interessante que pode ser sistematizado como um instrumento de apoio ao trabalho do professor. Mas, colocamos aqui uma ressalva. Dentre as professoras da presente pesquisa que citaram seus colegas como meios para se manterem informadas, duas delas informam-se exclusivamente dessa forma. Não estamos aqui nos opondo a essa possibilidade, mas alertando que esse não pode ser um recurso exclusivo de informação por restringir em muito as informações que poderiam chegar ao professor e, com isso, prejudicar o seu trabalho com EA.

Se somarmos as citações referentes à mídia (internet, revistas, jornais e televisão), ela representa um total de $75 \%$ dos meios pelos quais os professores entrevistados disseram se informar em relação à EA. De certo que a mídia atinge a maioria da população e acaba tendo um papel importante na formação dos cidadãos. Leff (2007) mostra-se crítico na maneira como a mídia aborda os temas ambientais:

(...) quando se trata de abordar temáticas mais críticas, como o posicionamento dos cidadãos a respeito da água, do aquecimento global e do desmatamento, a mídia não tem um critério bem construído. Muitas vezes as notícias ambientais são transmitidas de forma espetacularizada. Devemos estar atentos a isso. A mídia 
atinge mais pessoas do que a educação sistêmica. Todo mundo assiste TV. Desastres ecológicos são transmitidos constantemente (LEFF, 2007, p. 16).

Tristão (2004) também investigou a relação existente entre meio ambiente e meios de comunicação no seu estudo da incorporação da EA nas escolas de Vitória/ES. Para a autora a mídia absorveu a discussão ambiental e a difundiu para a população. Esse movimento acaba influenciando a ação pedagógica relacionada com as questões ambientais e, para autora, existe uma tendência dessas "práticas ideológicas serem assimiladas sem se compreender seus sentidos e suas possibilidades para a educação" (p. 160). O discurso da mídia não é neutro, é carregado das contradições e ideologias próprias da disputa do campo ambiental. Por isso, é necessário que o professor se coloque de maneira crítica perante as informações veiculadas pela mídia e que passe a questionar, juntamente com seus alunos, as mensagens por ela difundidas. De fato, apenas uma professora entrevistada mostra-se crítica em relação às informações provenientes dos meios de comunicações. Ela especifica o uso da internet em sua fala:

"Leituras, porque eu assino revistas cientificas, publicações e trabalhos. A internet tem coisa boa e coisa ruim que a gente tem que selecionar e publicações de livros mesmo. Eu leio bastante sobre isto porque eu gosto do tema (...)" (professora de ciências da escola estadual E).

Assim, como bem lembra Tristão (2004), termos como "harmonia", "santuário ecológico", "desastre" ou "inferno verde" aparecem diariamente na grande mídia e são difundidos e incorporados por professores e alunos sem que haja uma reflexão. Mas, isso não impossibilita que as informações difundidas pela mídia possam ser ferramentas usadas para trabalhos de EA:

Se essas informações passassem a ser trabalhadas como instrumento de compreensão da realidade do/a aluno/a, para além das aparências, transformando o conhecimento imediatista em conhecimento mais elaborado, mais questionador e reflexivo, aí sim, talvez as inter-relações entre as diversidades cultural, social e biológica provocassem uma mudança de comportamento e de atitude, uma transformação na conduta social dos cidadãos e cidadãs (TRISTÃO, 2004, p. 172).

Carvalho (1989), em sua pesquisa, também relata uma grande influência dos veículos de comunicação como divulgadora da temática ambientalista em oposição à baixa freqüência em que o sistema educacional foi citado pelos professores entrevistados, posição que só se diferencia da 
presente pesquisa pelo acréscimo, nesta, da internet, o qual, sendo um meio de comunicação mais recente, já faz parte do dia-a-dia da escola e mostra-se tão influente quanto a revista, o jornal e a televisão. Para o autor citado, o sistema educacional acaba sendo omisso nessas discussões. A presente pesquisa corrobora essa informação ao constatar que apenas sete $(23 \%)$ dentre os entrevistados disseram que se informam através de materiais voltados especificamente para educação ou EA, como a TV Escola e Futura, a revista Nova Escola, livros e cursos específicos sobre EA. Cinco são professores de Ciências, um é professor de Geografia e uma é professora de Artes:

"Eu procuro muito na internet, na televisão, no jornal. Participo muito de cursos. Quando tem palestras, por exemplo, palestras na Câmara, no Sesi, Senac, Esalq" (professor de Ciências e Matemática das Escolas Estaduais A e H).

"Através de livros, de programas da TV Escola, Globo Ecologia, a Futura (...) e livros. (...) Por causa (do projeto da escola), e isso é muito legal, porque por causa dos alunos eu voltei a ler (...) sobre o meio ambiente. Porque eles vão além, é muito legal. E aí você tem que estar sabendo do que eles estão falando, não dá para ficar atrás" (professora de Artes da Escola Particular C).

Essa idéia é ainda mais reforçada com as respostas que os entrevistados deram ao serem questionados sobre a existência ou não de orientação do MEC ou Diretoria de Ensino (DE) para trabalhos com EA. Dentre os professores que responderam essa pergunta, doze (40\%) responderam afirmativamente. Porém, entre esses quatro não souberam especificar suas respostas, duas professores da Escola Particular C trabalham com o projeto "Com-Vida" do MEC, dois professores de Geografia citaram os PCNs como material de apoio, uma professora de Geografia disse receber orientação das editoras de livros didáticos e três professores, apesar de acreditarem que existe algum tipo de orientação, questionaram a sua eficiência. Dentre os coordenadores, tivemos oito (73\%) que acreditam haver algum tipo de orientação por parte dos órgãos oficiais de educação, porém suas respostas também não foram muito detalhadas. Entre as respostas dos coordenadores que fazem referências a alguma instituição ou material, temos a DE, que recebeu três citações, os PCNs, que foram citados por duas entrevistadas e a Esalq, que foi mencionada em duas respostas.

É alarmante notar como a mídia passa a ter uma influência maior do que materiais que são produzidos por programas oficiais de educação, como os do MEC. Os PCNs foram apenas citados, mas ficou evidente que não são usados no dia-a-dia pela coordenação ou pelos professores como um material de apoio para seus trabalhos com EA. Denise Segura (2001) em sua pesquisa de EA nas 
escolas públicas também constatou esse fato. Das dezessete escolas que fizeram parte do seu estudo, apenas uma dispunha dos PCNs. Para essa autora, esse quadro ilustra a insuficiência de orientação e difusão dos materiais teóricos produzidos e podem nos ajudar a entender a dificuldades dos professores em articular no ensino formal as teorias e práticas de EA. De fato, muito do material produzido e das discussões realizadas sobre a temática ambiental parecem ficar à margem da realidade escolar. O que parece existir é uma deficiência de comunicação entre a escola e o campo de conhecimento da EA. Se de um lado essas informações e materiais não chegam à escola, do outro a escola parece não ir atrás. Todo o material produzido pelas instituições públicas de ensino, como o produzido pelo MEC e MMA, assim como a maioria das publicações científicas da área, estão disponíveis na internet. Vale lembrar que $47 \%$ dos professores disseram utilizar a internet para se manter informados, demonstrando haver acesso a esse meio de comunicação.

\subsubsection{A formação dos professores em Educação Ambiental}

Durante as entrevistas foi solicitado aos entrevistados que informassem os cursos de capacitação relacionados à EA que tivessem participado. Apesar de estimulados a detalhar mais a respeito dos cursos (instituições responsáveis, ano do curso, carga horária, temática, etc.), as respostas dos professores limitaram-se ao nome da instituição responsável pelo curso e apenas alguns professores relataram suas opiniões a respeito do curso em questão. Por isso, não fizemos distinções entre os cursos citados pelos professores e os classificamos e denominamos como "momentos formativos", independentemente de serem cursos, palestras, conferências ou capacitações.

Do total de professores entrevistados, dezenove (63\%) declararam que já participaram de algum momento formativo relacionado com EA, sendo quinze desses professores de escolas estaduais e somente quatro da rede particular. A tabela 3 reúne as instituições responsáveis pelos momentos formativos e a freqüência em que foram citados pelos professores, fazendo distinção entre as disciplinas e entre as redes particular e estadual.

As instituições responsáveis pelos momentos formativos em EA freqüentados pelos entrevistados foram a empresa Belgo-Mineira, do Grupo Belgo-Arcelor Brasil, a empresa Votorantim Celulose e Papel (VCP), do Grupo Votorantim, a empresa de embalagens longa vida 
Tetra Pak e as empresas estatais de Serviço Municipal de Água e Esgoto de Piracicaba (Semae) e Companhia Paulista de Força e Luz (CPFL). As instituições públicas citadas pelos entrevistados foram a DE, Esalq, Unesp, Serviço Social da Indústria (SESI) e Serviço Nacional de Aprendizagem Comercial (Senac).

Tabela 3 - Instituições responsáveis pelos momentos formativos em Educação Ambiental feitos pelos professores entrevistados e o número de vezes que foram citadas, em ordem decrescente Legenda: C (Ciências); G (Geografia); A (Artes); M (Matemática) e P (Português)

\begin{tabular}{|c|c|c|c|c|c|c|c|c|c|}
\hline \multirow{2}{*}{$\begin{array}{c}\text { Instituições } \\
\text { responsáveis pelos } \\
\text { momentos } \\
\text { formativos } \\
\end{array}$} & \multicolumn{3}{|c|}{ Rede Particular } & \multicolumn{5}{|c|}{ Rede Estadual } & \multirow[b]{2}{*}{ Total } \\
\hline & C & G & A & C & G & A & M & $\mathbf{P}$ & \\
\hline $\begin{array}{c}\text { Nunca fizeram } \\
\text { cursos }\end{array}$ & 3 & 1 & - & 3 & 1 & 1 & - & 1 & 10 \\
\hline DE & - & 1 & - & 6 & 1 & - & 1 & - & 9 \\
\hline Semae & 1 & - & - & 4 & 1 & - & - & - & 6 \\
\hline Esalq & - & 2 & - & 1 & - & - & 1 & - & 4 \\
\hline Votorantim & - & - & - & 1 & 1 & - & 1 & - & 3 \\
\hline Tetra Pak & - & - & - & 2 & 1 & - & - & - & 3 \\
\hline Belgo-Mineira & 1 & - & - & 1 & - & - & - & - & 2 \\
\hline $\begin{array}{c}\text { Conferências da } \\
\text { Rio }-92\end{array}$ & 1 & - & - & - & - & - & - & - & 1 \\
\hline CPFL & - & - & - & 1 & - & - & - & - & 1 \\
\hline Senac & 1 & - & - & - & - & - & - & - & 1 \\
\hline SESI & - & - & - & 1 & - & - & - & - & 1 \\
\hline Unesp & - & - & - & - & 1 & - & - & - & 1 \\
\hline Unimep & - & - & - & 1 & - & - & - & - & 1 \\
\hline Não especificou & - & - & 1 & - & - & - & - & - & 1 \\
\hline
\end{tabular}

O que primeiramente nos chama a atenção é o número elevado de professores que declararam nunca ter participado de cursos, capacitações ou qualquer outro tipo de formação 
relacionada à EA. Entre os professores das escolas particulares, temos quatro (50\%) entrevistados que nunca fizeram cursos em comparação a seis (27\%) professores de escolas estaduais.

As escolas particulares disseram ter dificuldade em participar das capacitações, cursos e/ou palestras que são disponibilizados para os professores da rede estadual. A coordenadora da Escola Particular B nos relata:

“A DE, o que ela faz com as escolas particulares? (...) se a gente quiser alguma coisa, a gente tem que entrar no site, verificar se é uma coisa que a gente possa participar. Se for uma orientação, por exemplo, um projeto do Estado, nós, da rede privada não podemos trabalhar. Aquilo é especifico para rede pública. Existe uma separação. Talvez pelo número excessivo de escolas que eles tenham".

Porém, também notamos por parte das escolas particulares uma resistência muito forte em integrar-se com o sistema de ensino público. Vale lembrar que cinco escolas particulares com as quais tentamos entrar em contato nem aceitaram nos receber para maiores explicações e esclarecimentos a respeito da pesquisa. Encontramos novamente na fala da coordenadora da Escola Particular B pistas que podem nos ajudar a entender esse isolamento das escolas particulares em relação às escolas públicas:

“(...) Esse ano o colégio participou do desfile cívico da cidade. (...) fomos o único colégio particular a participar disso. (...) Muitas vezes a rede pública tem infinitamente mais recursos, mais acessos do que muitas escolas da rede privada".

Assim, muitos materiais, informações e capacitações acabam chegando às escolas particulares através de professores que lecionam simultaneamente em escolas particulares e estaduais, e esses acabam formando um elo de ligação entre a rede particular e estadual de ensino:

"Nós temos aqui professores do Estado que recebem materiais riquíssimos sempre. Ai eles trazem, mas não chega até nós..." (diretora da Escola Particular E).

A diretora da Escola Particular E informou que alguns dos seus professores já participaram de momentos formativos da empresa Belgo-Mineira e Semae, mas que esses professores já não se encontram mais na escola. As coordenadoras das Escolas Particulares A e B afirmaram que seus 
professores fazem cursos de capacitações dentro do próprio sistema de ensino da qual a escola faz parte e que esses nem sempre são direcionados para a EA:

"Eles fazem sempre capacitação na matriz nossa em São Paulo. Periodicamente eles se reúnem (...) às vezes eles escolhem temas ligados ao meio ambiente e envolvem todo o grupo de professores independente das disciplinas nas palestras que são feitas lá" (coordenadora da Escola Particular A).

Dentre os professores de Ciências das escolas particulares, apenas a professora da escola B já participou de cursos, capacitações ou qualquer outro tipo de formação relacionado à EA. Essa professora também é coordenadora da Escola Estadual J selecionada para a pesquisa. Entre os professores de Ciências entrevistados das escolas estaduais, três (21\%) nunca fizeram cursos relacionados com EA. Uma professora que leciona as disciplinas de Ciências e Matemática na Escola Estadual A afirmou que só participou de momentos formativos em EA enquanto professora de Matemática, oferecidos pela CPFL e pela DE. Dois professores citaram somente os momentos formativos da DE, outros dois somente os momentos formativos da Tetra Pak, enquanto três outros professores citaram mais de duas instituições como responsáveis pelos momentos formativos que participaram. Três professoras de Ciências disseram que já freqüentaram algum tipo de formação relacionado à EA, mas há muito tempo, e não se lembram mais quais. Uma das professoras justifica:

“(...) hoje em dia a gente percebe que os cursos oferecidos são para testar você. (...) você ensina para eles o que foi de bom que você fez na sala de aula. (...) Eles querem coletar da gente o que a gente faz. Basicamente no Brasil o professor aprende sozinho a se virar. Ninguém ensina nada para ele. Então, se deu sorte é porque realmente este cara foi um batalhador, ele foi sozinho, ele fez sozinho e deu certo. (...) dizer para você que há uma estrutura muita bem montada da Secretaria de Educação (...) isto é mentira. Então, é por conta própria que o professor consegue, esbarrando aqui, esbarrando ali, ele consegue arrumar as arestas, mas sozinho. Mas isto são longos anos... (...) Eu desisti destes cursos" (professora de Ciências da Escola Estadual G).

Entre os professores de Geografia, somente o professor das Escolas Particulares B e E e o professor da Escola Estadual F nunca fizeram cursos, capacitações ou qualquer outro tipo de formação relacionado à EA. Os outros professores entrevistados participaram de momentos formativos na DE, Esalq, Unesp, Semae, Votorantim e Tetra Pak.

Em relação as outras disciplinas, temos a professora de Artes da Escola Particular C que na época em que morava em Florianópolis participava ativamente de encontros, cursos e palestras sobre 
meio ambiente. A professora de Matemática da Escola Estadual C que participou dos momentos formativos oferecidos pela Esalq e pela empresa Votorantim. A professora de Artes da Escola Estadual $\mathrm{C}$ e a professora de Português da Escola Estadual $\mathrm{K}$ nunca tiveram qualquer tipo de formação relacionada à EA.

A instituição mais citada pelos professores entrevistados que declararam já ter participado de momentos formativos de EA foi a DE, citada por nove $(30 \%)$ professores. Desses apenas a professora de Geografia da Escola Particular F pertence à rede particular. Essa professora é aposentada pelo Estado e na época em que participou dos momentos formativos da DE ainda lecionava em escolas estaduais e era convocada com freqüência a participar desses tipos de atividades. Os professores da rede estadual de ensino acabam tendo facilidades em participar das capacitações da DE e dos seus parceiros. Eles são dispensados durante seus horários de aula:

"Se a DE concede a licença com abono de falta (...) nós fazemos um acordo aqui na escola. Se for horário de aula deles eu, enquanto coordenadora, monto uma atividade para ocupar os alunos..." (coordenadora da Escola Estadual H).

Os momentos formativos ministrados pela DE citados pelos professores participantes dessa pesquisa variam desde um encontro com o assistente técnico pedagógico (ATP) até palestras com convidados da DE, capacitações e teleconferências, atividades essas que, na maioria das vezes, são parte do desenvolvimento de projetos da DE ou em parceria com outras instituições e " acontecem na secretaria ou em alguma escola que marcam" (professor de Ciências da Escola Estadual E). Nas palavras da professora de Geografia e História da Escola Estadual H:

“(...) todo mês, geralmente uma vez ao mês, nós temos uma capacitação... Teleconferência sobre meio ambiente. Porque a escola hoje está muito preocupada com isto. Há uns tempos atrás não, mas a gente percebe que hoje, uns dois anos para cá, a escola está se envolvendo mais. Então a diretoria sempre convoca a gente... A última que nós fomos foi sobre reciclagem, foi muito legal...”.

Os momentos formativos oferecidos pela DE são bastante seletivos não só em relação à rede particular, mas também em relação aos professores da escola estaduais. Os professores são convocados dependendo da disciplina que lecionam - geralmente Ciências e Geografia - por carga horária ou pelas séries de que são responsáveis. Notamos que há uma preferência pelas disciplinas consideradas "ambientais" nos momentos formativos de EA oferecidos pela DE, o que reforça a 
tendência, já observada nesta pesquisa, de desenvolvimento de uma EA a partir dos conteúdos programados de Ciências e Geografia, tendendo, portanto, para uma EA de natureza conservadora.

Alguns professores também se mostraram críticos em relação à superficialidades dos momentos formativos oferecidos pela $\mathrm{DE}$, muitas vezes não indo além dos conhecimentos que os professores já possuem:

“A gente acaba tendo algumas capacitações, mas não são aprofundadas. É super interessante, ajuda bastante, mas se você não se interessa... que nem eu fiquei inconformada. Dai eu peguei e fui atrás. Mas tem pessoas que acham que é só isso: vamos fazer um cartãozinho de papel reciclado fica bonito e está bom. E o alumínio? E o plástico? Joga fora? Dai não adianta nada. Para mim o trabalho está incompleto" (professora de Ciências da Escola Estadual D).

A Esalq foi citada por quatro (13\%) professores como responsável por momentos formativos em EA. Um desses momentos foi no início da década de 90:

"Foi o primeiro curso sobre a questão ambiental da Esalq. Foi logo na Eco92, sabe? Foi na década de 90” (professora de Ciências da Escola Particular F)

Outro momento formativo oferecido pela Esalq foi sob a coordenação do professor Marcos Sorrentino:

“(...) já participei lá da Esalq. Teve um curso de educação ambiental muito legal, foi lá na Florestal. Uns quatro anos atrás. (...) Se eu não me engano, foi uma semana de curso dado em janeiro. Foi super completo, desde o conceito de educação ambiental...Foi o Sorrentino, ele coordenou com uma equipe bem grande, faz muito tempo...Não me lembro a data" (professora de Ciências da Escola Estadual F).

O último momento formativo realizado pela Esalq e citado por um dos professores entrevistados aconteceu em 2001 e foi freqüentado pela coordenadora e professora de Geografia da Escola Particular D:

"Eu fiz um curso de especialização na Esalq, em 2001. (...) Foi Educação Ambiental para Sociedades Sustentáveis. Foi um curso de um ano de especialização. Foram vários professores. A gente fazia as aulas aos sábados, tinha a distância também com os alunos".

Outras instituições do sistema educativo formal e informal citadas pelos entrevistados como responsáveis pelos momentos formativos por eles freqüentados foram a Unimep, Unesp, Senac, 
SESI e Conferência Rio-92, com uma citação cada. As palestras do Senac, SESI e da Conferência Rio-92 foram apenas citadas pelos professores, não sendo possível detalhar os temas ou palestrantes.

As empresas também foram mencionadas como responsáveis pelos momentos formativos em EA freqüentados pelos entrevistados. O interessante é que o programa de EA das empresas BelgoMineira, Votorantim, Tetra Pak e Semae foi considerado como capacitações e também como projetos de EA desenvolvidos nas disciplinas para catorze professores entrevistados. Porém, outros oito professores entrevistados, mesmo tendo passado pelas mesmas atividades dos programas de EA dessas empresas e terem desenvolvido projetos, não os citaram quando perguntados sobre cursos de EA que tinham freqüentado.

Dentre esses, o do Semae foi o mais citado pelos professores entrevistados, tendo seis $(20 \%)$ citações. Somente uma professora da rede particular participou dos momentos formativos oferecidos pelo Semae. Ela é professora de Ciências da Escola Particular B e também coordenadora da Escola Estadual J. Os momentos formativos oferecidos pelo Semae começam com uma capacitação para os professores e depois esses desenvolvem atividades com seus alunos:

“(...) eles fazem uma palestra, convocam dois ou três professores de cada estabelecimento, chega até ter a possibilidade de vir uma van e mostrar todo o processo de filtração da água. Eles estão voltados especificamente para água" (coordenadora da Escola Particular B).

Os professores mostram-se bastantes críticos em relação aos momentos formativos oferecidos pelo Semae, realizados em parceria com a DE. A professora de Ciências da Escola Estadual E faz críticas em relação à falta de continuidade:

“Estas capacitações que estavam no projeto Água Doce da ano passado foram bem legais... Eu não conhecia a região e nós tivemos a oportunidade de conhecer a bacia hidrográfica do rio Piracicaba. (...) Contribui muito porque eu pude falar (...) melhor para os alunos sobre a bacia hidrográfica e tudo mais. (...) só que eles chamaram para capacitação este ano somente professor que trabalha com a $\sigma^{a}$ série. Eu participei todo o ano passado, desenvolvi todo o projeto ano passado e não me chamaram para capacitação este ano. Então eu não sei o que está acontecendo (...) para continuar a desenvolver com os alunos. Então não tem uma continuidade, sabe? (...) Estes que trabalharam vamos voltar, vamos discutir o que aconteceu, vamos ver os resultados, vamos dar continuidade. Então muitas vezes eu acho que o trabalho de educação ambiental não dá certo porque é feito muito pontual. (...) Não é assim... eu acho que educação ambiental você tem que trabalhar continuamente". 
Outras instituições nas quais os entrevistados se referenciam foram as empresas Votorantim e Tetra Pak, três citações cada, empresa Belgo-Mineira e CPFL, com uma citação cada. Os momentos formativos de EA oferecidos por empresas aos professores fazem parte de uma estratégia para orientar os docentes na realização de projetos idealizados pelas próprias empresas ou simplesmente para explicar como devem ser utilizados os materiais didáticos desenvolvidos e oferecidos pela empresa.

A empresa Tetra Pak desenvolveu um kit didático sobre reciclagem e distribui nas escolas do Estado:

"A Tetra Pak mandou uma caixa para todas as escolas com livros, livro de papel reciclado, mandou alguns cartazes, mandou uma fita de vídeo que chama Dom Quixote Reciclado. Eles mandaram este material e a gente participou de uma videoconferência e eu estou para começar a trabalhar com eles" (professora de Ciências da Escola Estadual B).

A unidade de Piracicaba da empresa Belgo-Mineira também realiza palestras com o objetivo de orientar as escolas participantes a respeito do tema e material didático do projeto escolhido a cada ano. O núcleo de EA da empresa Votorantim mantém palestras e orientações para grupos de professores e alunos para que esses desenvolvam atividades ligadas a temática ambiental.

A CPFL também mantém um programa direcionado às escolas públicas e particulares, chamado PROCEL nas escolas. Além dos materiais didáticos oferecidos, mantém também um curso direcionado aos professores.

A formação continuada dos professores em relação a EA é um outro ponto discutido por vários autores (GUERRA; GUIMARÃES, 2007; GUIMARÃES, 2003; MEDINA, 2001; SORRENTINO, 2001). Para Guimarães (2003), os cursos direcionados para EA estão mais preocupados em formar multiplicadores - os professores que freqüentam os cursos transmitem as informações e técnicas metodológicas aprendidas aos seus colegas. Para o autor, essa simples difusão de informações não irá surtir efeitos significativos no cotidiano escolar. Realmente, a formação de professores vai muita além do treinamento e capacitação, sendo um processo que inclui a reflexão dos docentes sobre suas ações pedagógicas, "a fim de (re)construir conhecimentos, atitudes e estratégias de ensino" (NÓVOA, 1995; SHÖN, 1995 apud GUERRA; GUIMARÃES, 2007, p. 159). 
Para Sorrentino (2001) mesmo que os professores consigam absorver dos cursos alguns conceitos, técnicas e conteúdos e incorporá-los na sua prática educativa, essa acaba sendo uma iniciativa autônoma desse professor, uma vez que ele se sente isolado e impotente para promover qualquer mudança mais profunda no ambiente escolar como um todo. É nesse sentido que Guimarães (2003) defende que a formação de professores em EA seja feita a partir de uma perspectiva crítica, que se propõe a formar dinamizadores, e não multiplicadores, de ambientes educativos:

Não é somente dar instrumental técnico-metodológico, como parece ser a tendência nas propostas de formação de multiplicadores em Educação Ambiental, mas propiciar uma formação político-filosífica (além de técnico-metodológico), para transformá-lo em uma liderança apta (...) em contribuir na construção de uma educação ambiental, em que o educador ambiental se apresente como um dinamizador de um movimento conjunto, capaz de criar resistência, potencializar brechas e construir, na regeneração, a utopia como o inédito viável da sustentabilidade (GUIMARÃES, 2003, p. 117).

Outro aspecto discutido por Medina (2001) é a falta de continuidade e acompanhamento nos cursos oferecidos aos professores que, segunda a autora, prejudica a qualidade da formação dos docentes. Guerra e Guimarães (2007) alertam também para o fato de a formação dos professores em EA ser deixada, na maioria das vezes, por conta de iniciativas externas, como ONGs, empresas ou livros didáticos. Para os autores, o professor desta maneira é "indiretamente formado" (p.162) o que pode contribuir para o quadro de má formação em relação à EA dos docentes. De fato, verificamos o quanto a influência externa faz-se presente na formação dos professores entrevistados, seja em relação às maneiras utilizadas pelos professores para se manterem informados em relação à EA (Tabela 2), como também em relação às instituições que fomentam a formação em EA dos professores (Tabela 3).

Resumidamente, as respostas dos professores apresentadas nessa primeira parte da análise nos permitiram traçar um perfil do professor do ensino fundamental que tem incorporado nas suas práticas de ensino a temática ambiental e, na maioria das vezes, conseguido desenvolver trabalhos com EA. Assim, temos uma maior participação de mulheres (23) em relação aos homens (7). Em relação à formação acadêmica, encontramos um equilíbrio entre as instituições de ensino superior público (14) e privado (15) e, entre os professores que estão cursando ou já concluíram algum curso 
de pós-graduação, temos três em programas da área educacional. Em relação à idade e ao tempo de magistério, temos um grupo bastante variado, que vai dos 23 aos 57 anos e de um mês a 37 anos, respectivamente. O levantamento do tempo de permanência na escola em que cada professor foi entrevistado nos levou a constatar a alta rotatividade desses professores. Fizemos um paralelo entre o tempo de magistério e o tempo de atuação na escola com o fato de desenvolver ou não atividades extracurriculares de EA. Professores com menos de cinco anos de atuação profissional e/ou no primeiro ano na escola demonstraram uma maior dificuldade de desenvolver trabalhos com EA do que professores que não estão nesses grupos. As disciplinas de Ciências (18) e Geografia (7) foram as maiores representantes na pesquisa, apesar de termos representantes nas disciplinas de Artes (2), Matemática (2) e Português (1). Entre os incentivos e as motivações que levam os professores a trabalharem com EA temos dois grupos. O primeiro encontrou nos incentivos externos, de órgãos governamentais ligados à educação ou núcleos de EA do setor empresarial, motivações para realizarem trabalhos com EA. O segundo grupo de professores tem nas motivações pessoais o seu maior incentivo. E, entre esses professores, podemos notar um engajamento maior nos trabalhos realizados de EA do que entre os professores que formam o primeiro grupo. Em relação aos meios pelos quais os professores se mantêm informados, temos uma preferência pelos veículos de comunicação de massa em relação aos meios que são direcionados para as áreas de educação e/ou EA. A influência da mídia nas discussões da problemática ambiental na sala de aula mostra-se evidente. Assim, cabe ao professor, juntamente com seus alunos, se posicionarem criticamente diante dessas informações. E, por último, em relação aos cursos, palestras ou qualquer outro tipo de formação em EA, disponíveis para os professores, notamos, primeiramente, um número elevado de professores entrevistados que nunca fizeram cursos relacionados à EA. Chama a atenção também o número de professores da rede particular $(50 \%)$ em relação aos professores da rede pública $(32 \%)$ que não fizeram cursos de EA. De fato, a rede particular, além de manter-se isolada, tem uma dificuldade de acesso aos cursos disponíveis à rede pública de ensino. Também alguns professores se posicionaram de maneira crítica em relação aos cursos oferecidos, criticando a falta de preparo dos ministrantes, pouca elaboração e um direcionamento preferencial para as áreas de Ciências e Geografia e para professores efetivados e das séries iniciais do ensino fundamental. 


\subsection{As Concepções de Educação Ambiental dos professores entrevistados: tendências reveladas}

Do mesmo modo que um olhar mais atento ao campo da EA nos revela a existência de múltiplas correntes, indicando que a EA pode ser idealizada a partir de diferentes discursos e, consequentemente, refletida em diferentes práticas, descobrimos nas escolas selecionadas para a presente pesquisa que o cenário de incorporação da EA também não acontece de maneira uniforme. Dessa maneira, tendo como apoio o levantamento bibliográfico do capítulo 2 e, principalmente, as tendências de EA elaboradas por Carvalho (1989) e Tozoni-Reis (2002) e os quadros tipológicos organizados por Sauvé (1997) elaboramos um quadro teórico das concepções de EA dos professores do ensino fundamental das escolas de Piracicaba. Os limites que separam as tendências da EA são delicados e, por vezes, os elementos que aparecem numa também se repetem nas outras, pois compartilham de pontos semelhantes. Porém, tal categorização torna-se uma importante ferramenta de orientação para as ações pedagógicas voltadas para as questões ambientais, uma vez que explicita a representação de conceitos-chaves para o campo da EA de todos os atores envolvidos nas práticas educativas, negando, assim, a idéia de um possível consenso existente no campo. Dessa forma, a partir das falas dos entrevistados a respeito do seu entendimento e definição sobre desenvolvimento sustentável, meio ambiente, educação e educação ambiental, as várias maneiras de se pensar e praticar EA no ensino fundamental são reveladas, expondo as seguintes tendências de EA: Indefinida, Ingênua-romântica, Convenciona, e Questionadora.

A tendência Indefinida abrange as respostas dos entrevistados que pouco conseguiram explicitar seu conhecimento sobre EA, meio ambiente ou desenvolvimento sustentável, muitas vezes sendo difícil interpretar as respostas dadas pelos professores. Apresentam um discurso pouco coeso, impreciso e, por vezes, confuso, demonstrando uma dificuldade em elaborar os conceitos do que esses termos significam para eles.

Essa tendência reúne respostas como a da professora de Ciências da Escola Particular B sobre desenvolvimento sustentável:

“(...) é o avanço que está acontecendo, eu não sei desde quantos milhões de anos, e que o homem não está se dando conta que o avanço está sendo em certa parte prejudicial a ele (...) O avanço em certas situações, mas está sendo ruim".

Ou como a da professora de Ciências da Escola Estadual B que simplesmente não consegue definir o termo: 
“Ah, fico te devendo isto daí...".

E como a do professor de Ciências da Escola Estadual E, que apenas repete a expressão sustentável, sem conseguir ir além disso:

"Para mim desenvolvimento sustentável é procurar algum tipo de atividade que garanta a sustentação... dos seres vivos".

As respostas desse grupo também são amplas demais, como a definição de meio ambiente da professora de Ciências da Escola Estadual J:

“... sobrevivência. Para mim é essa a palavra chave”.

Ou a definição de educação do professor de Ciências das Escolas Estaduais A e H e da Escola Particular E, respectivamente:

"Acho que educação é tudo. (...) não existe cultura sem educação”.

"Educação é tudo que você ensina. Uma vida melhor para outra pessoa. Tudo".

Assim, a definição de EA também acaba tendo pouco sentido, como a do professor de Ciências e Matemática das Escolas Estaduais A e H:

"Educação ambiental já existia na época de Cristo. Quer dizer, nós fomos só tirando, tirando... Não tinha educação, tudo era bonito, era bonito dá tiro, era bonito matar... E não existia quem pensasse em educação ambiental. Então é o que nós estamos vendo agora? Rio poluido (...) Se tivesse educação, o rio não estaria deste jeito. Então acho que educação ambiental é fundamental para nossa subsistência...”.

Os dois professores de Ciências, da Escola Estadual E e da Escola Particular B, respectivamente, apenas se referem à EA como o estudo do meio ambiente, também se incluem nessa categoria:

"Estudo do meio ambiente, dos seres vivos, tudo que envolvem eles". 
“... educação ambiental é como ser educado para o ambiente. (...) É você ser educado para ter um ambiente para você cada vez melhor. A educação ambiental faz parte do seu próprio sustento".

Concordamos que a tendência Indefinida inclui professores que pouco se esforçaram para elaborar suas respostas. Porém, para aqueles que procuraram organizar suas idéias, é preocupante o fato de pouco conseguirem estruturá-las. De fato, termos como EA e desenvolvimento sustentável são relativamente recentes e carregam no seu bojo toda contradição e disputas ideológicas pertencentes ao seu campo de conhecimento. Porém, o significado de educação e os desdobramentos que esse termo possa ter dizem muito da maneira como o professor irá se portar diante da sua atuação profissional e irão determinar as escolhas pedagógicas feitas por ele.

O segundo grupo de respostas dos professores expõe a tendência que denominamos de Ingênua-romântica. Esse grupo busca, através da EA, encontrar o equilíbrio que existia na natureza e que foi destruído pela ação predatória do homem. Assim, a EA está voltada para restabelecer a igualdade entre o ser humano e a natureza, sendo que deveria ser uma educação voltada para o meio ambiente "igual a educação que você tem que ter com seu semelhante" (professora de Ciências da Escola Particular E).

O ser humano produz os desastres e a destruição da natureza, sendo ele assim representa a causa do desequilíbrio. O meio ambiente ideal é concebido a partir de uma aparente harmonia social, através da concepção de um ser humano genérico:

"Meio ambiente seria... a harmonia que existe entre os seres vivos e a natureza. A harmonia que existe entre eles e as condições fisicas que deve existir. (...) se você for fazer uma reflexão mesmo (...) o próprio homem está prejudicando a natureza (...) devido à poluição está tendo o desequilíbrio”, (professora de Matemática da Escola Estadual C).

"Eu acho que é o meio que a gente vive e que se relaciona com a natureza. Mais infelizmente a gente esta se sobrepondo a ela. A gente não está respeitando o espaço dela (...) eu acho que a gente tinha que se relacionar melhor com a natureza” (professora de Geografia da Escola Estadual J).

O conceito ingênuo de desenvolvimento sustentável é formado por esses professores, sem considerar o histórico de contradições e disputas que esse termo carrega:

"Desenvolvimento sustentável acho que é você conseguir manter as espécies vivas sem destruir". (professora de Geografia da Escola Estadual D). 
Assim, um lado romântico é evidenciado no conceito de EA, estabelecendo uma relação romântica entre homem e natureza:

"Você tem que amar as coisas que fazem parte da natureza, e não destruir. Tem que proteger essas coisas...” (professora de Ciências da Escola Estadual D).

Outra característica dessa tendência é ver a EA como salvação para a crise ambiental, uma postura ingênua de responsabilizar somente o indivíduo e não a sociedade como um todo:

"Eu acho que é a saída para que a gente sobreviva dentro desse planeta. Ou as pessoas acordam e percebem que são as nossas atitudes que podem mudar o rumo da nossa história, que é tenebroso... Se você pensar o caminho que o homem está levando o planeta. Ou a gente consegue fazer as pessoas pararem para pensar a importância e a responsabilidade de cada uma perante todos nós, o nosso ar, as pessoas e tudo, ou a gente vai acabar destruído" (professora Artes da Escola Particular C).

Nessa concepção, as práticas de EA limitam-se muita às dinâmicas e técnicas de sensibilização, procurando atrair os alunos para o "lado do bem", apostando que indivíduos sensibilizados com o nível de degradação atual da natureza sejam capazes de mudar seu comportamento diante dela, trabalhando para a superação de uma ética antropocêntrica. Para TozoniReis (2002), essa abordagem de EA acredita na existência de um homem puro, a-histórico, assim como a natureza seria também a-histórica e harmônica.

Uma terceira tendência construída através das falas dos entrevistados é a Convencional, assim denominada, pois se mostrar tradicional, conservadora e sustentada e sustentadora do paradigma científico.

Nas definições de desenvolvimento sustentável fica claro que para esses professores o meio ambiente é um recurso a ser utilizado pelo ser humano:

“(...) Desenvolvimento sustentável é quando você consegue ter o seu sustento sem reduzir recurso. Você consegue sobreviver junto com (...) a natureza" (professora de Ciências da Escola Particular C).

"Desenvolvimento sustentável é quando a gente utiliza o meio ambiente sem que a gente cause a destruição (...) de uma maneira que a gente use, que a gente precise, mas que não estrague..." (professora de Ciências da Escola Estadual F). 
"Não dá só para tirar da natureza o que a gente precisa. Há uma necessidade muito grande, a população vem crescendo muito. Então, o que tem que fazer? Tem que tirar da natureza sim, mas só o necessário e tentando repor isso. Viabilizando economicamente a utilização desses recursos naturais (...) Então, o desenvolvimento sustentável está ligado à conservação, à preservação, o uso racional dessa natureza e dos recursos que nós temos" (coordenadora e professora de Geografia da Escola Particular D).

Nota-se também certa ingenuidade nas respostas do professores. Como determinar o uso adequado de recursos naturais que possibilite e sustente as necessidades humanas ao mesmo tempo em que não se destrói a natureza? Há uma aposta que, através do conhecimento científico e do desenvolvimento de tecnológicas, poderemos usufruir dos recursos naturais sem que isso represente a destruição da natureza, pois, afinal, o ser humano depende da natureza para sua sobrevivência.

O conceito de meio ambiente também é aqui definido às vezes de modo superficial ou generalizado:

"Meio ambiente? É tudo que nos cerca" (professora de Ciências da Escola Estadual J).

"É um conceito completo porque meio ambiente é tudo que envolve o indivíduo, o ser vivo. Desde a sala de aula dele, o corpo dele..." (professora de Ciências da Escola Estadual F).

E às vezes se relaciona meio ambiente apenas em seus aspectos físicos, químicos e biológicos da natureza:

"É a interação do homem com o ambiente onde ele... se relaciona... com os seres vivos. (...) No caso, como eu faço a parte teórica, seria mais ecossistemas. Ecossistemas formados por seres vivos e como eles se relacionam com os seres abióticos, água, luz, temperatura, etc." (professor de Ciências da Escola Estadual G).

Assim, o conceito de EA dos professores não é diferente do que daquilo que já é ensinado dentro do currículo de Ciências e/ou de Geografia:

“... é conhecimento de tudo que nos cerca... até elementos químicos da natureza, das plantas. São todos os conhecimentos que nós temos e que tentamos passar para os alunos em relação ao meio em que a gente vive..." (professora de Ciências da Escola Estadual D). 
“(...) um estudo sobre o meio ambiente, como preservar, como utilizar sem degradar o meio ambiente... importantíssimos na vida deles. Educá-los para o futuro (...) como vai ser o ar, a chuva, vamos ter água? Então para vida deles educação ambiental seria tudo..." (professora de Geografia da Escola Estadual $\mathrm{H})$.

A EA acaba sendo uma transmissão de informações, de conhecimentos que o educando precisa saber sobre o meio ambiente, para melhor preservá-lo e conservá-lo para as gerações futuras:

“(...) a pessoa aprende matemática, aprende português, apreende inglês, mas ele tem que aprender também a gerenciar, nem que seja na casa dela, os recursos da natureza, ou seja, evitar... jogar lixo na calçada... reciclar material, não jogar materiais que poderiam ser aproveitados no lixo..." (professor de Geografia da Escola Estadual F).

E o professor é o agente que informará seus alunos corretamente, como observamos nas respostas das professoras sobre o papel do professor na educação dos alunos:

“(...) Porque você está pondo na cabeça... pondo não, não é a palavra certa... Você está colocando para os alunos o que é correto e o que não é. E eu acho que dentro da escola se a gente insiste alguma coisa vai ficar" (professora de Ciências da Escola Estadual J).

"Pelo menos para as crianças eu sou a única fonte de informação deles. (...) Se meu trabalho for bom eles vão ser bem informados, se meu trabalho não for eles não vão" (professora de Ciências da Escola Particular C).

$\mathrm{Na}$ tendência Convencional reúne-se a maioria dos professores entrevistados. Há uma supervalorização do conhecimento científico na EA, tanto no que se refere à educação quanto à EA. A ética antropocêntrica prevalece nas relações estabelecidas entre sociedade e natureza (TOZONIREIS, 2002). As práticas de EA conduzidas por essa tendência se referem ao desenvolvimento de comportamentos ecologicamente corretos. A EA tem como porta de entrada no ensino formal as disciplinas de Ciências e Geografia.

A última tendência revelada é a que denominamos aqui de Questionadora. O discurso apresenta um diferencial que permite ir além das demais tendências até aqui apresentadas.

Existe um questionamento crítico que até então não é visto na fala dos demais professores: 
"Antes de falar de desenvolvimento sustentável primeiro a gente tem que perguntar: sustentável para quem? Sustentável de que?... se for sustentável para os grandes produtores, você tem que na verdade aumentar a produção. Desmatar $e$ aumentar as áreas produtivas. Se for sustentável para floresta você tem que diminuir a produção” (professor de Geografia das Escolas Estaduais B e E).

As relações internas da sociedade são incluídas nas definições de meio ambiente. $\mathrm{O}$ conceito de meio ambiente como também sendo o espaço construído está muito presente, principalmente entre os professores de geografia:

"Meio ambiente é tudo que está externo a nós. Da pele em diante. Só que a convivência... o espaço da convivência (...). Eu acho que meio ambiente é o lugar da interação do ser humano com o espaço. Ai esse espaço inclusive são os outros seres humanos, os espaços construidos, espaço natural e tudo mais (...) eu acho que educação tem ligação com o trabalho, atuação, esclarecimento (...) a educação ambiental seria esse trabalho, esse esclarecimento e essa atuação dentro do seu ambiente. Para melhorar, para prevenir, para preservar..." (professor de Geografia das Escolas Estaduais B e E).

Assim, a EA, ao ser inserida no espaço escolar, ganha uma dimensão que vai além dos aspectos biológicos e físicos da natureza. Como a resposta da professora de Português da Escola Estadual K, ao ser perguntada como enxerga a EA na escola:

"Respeitando o meio ambiente, respeitando a sala de aula, como um ambiente de estudo e principalmente com a consciência que o fato de desperdiçar papel é produzir mais lixo. Fazer com que eles tenham essa consciência e possam ser os multiplicadores disso. Para onde eles forem, quando constituirem famílias. Porque quando você assimila e desenvolve essa consciência e incorpora nunca mais você vai fazer alguma coisa contra o meio ambiente".

Também reconhece a necessidade de um trabalho interdisciplinar e as dificuldades que implicam essa metodologia:

“(...) educação ambiental dentro da legislação é transversal. Todas as disciplinas teriam que estar dando uma contribuição (...) Acho que através de projetos mesmos e que através deste projeto mesmo possa ser feito um trabalho interdisciplinar. Um projeto enxuto, com objetivos claros e dentro da realidade de uma escola, de tempo e espaço, e mesmo assim que depois possa ser avaliada. Que a maior parte dos professores da área possam estar participando e isto deve ser um papel positivo na educação ambiental" (professor de Geografia da Escola Estadual C). 
Esse grupo de entrevistados reunidos nessa tendência de EA também tem esclarecimento da importância do seu papel de educador:

"É formar pessoas que possam refletir, que possam olhar a vida com uma outra ótica (...) Educação é desenvolver consciência política, ética e ecológica. Educação é convivência, convivência saudável (...) Fazer com que as pessoas cresçam melhores (...) Educar para a cidadania." (professora de Português da Escola Estadual K).

Porém, é importante esclarecer que os professores reunidos nesse grupo enfrentam as mesmas dificuldades que seus colegas para incorporar a problemática ambiental nas suas práticas de ensino. Isso se deve ao isolamento desses professores nas escolas que lecionam e da pouca repercussão das suas idéias entre seus colegas. Podemos juntar a esse fato à falta de estrutura e de recursos que as escolas enfrentam atualmente e mesmo o todo processo de desvalorização da função do docente e da educação no Brasil, o que dificulta e até mesmo impossibilita os trabalhos referentes à EA. Assim, embora mostrem um avanço no entendimento de meio ambiente e de EA, isso pouco reflete nas práticas por eles desenvolvidas. Acreditamos que o diferencial desses professores, identificados na tendência Questionadora em relação ao demais professores é que esses justamente possuem uma postura mais crítica diante da sua atuação profissional e maior clareza do que seja educação e do seu papel de educador.

Resumidamente, temos o seguinte quadro de tendências de EA reveladas na análise das repostas dadas pelos professores, quando lhes foi perguntado sobre as definições de desenvolvimento sustentável, meio ambiente, educação e EA. A maioria dos entrevistados indicou ter uma visão de EA que nos remete a uma tendência Convencional. O conhecimento científico é altamente valorizado e acredita-se que através desse conhecimento e de mudanças de atitude (reciclar sem reduzir ou usufruir da natureza sem destruir) conseguiremos superar a crise ambiental. Assim, as mudanças não se referem à relação existente entre sociedade e natureza. Desta maneira, a EA ao se incorporar ao currículo escolar pouco se diferencia das atividades que as disciplinas de Ciências, principalmente, e Geografia até então vinham realizando. Se nos atentarmos ao fato de que justamente as disciplinas de Ciências e Geografia foram as mais representadas na presente pesquisa, não é de se surpreender que essa tendência é a que reúne a maioria dos professores entrevistados. Uma parte das falas dos entrevistados evidenciou um grupo que pouco explicitou seu entendimento 
dos termos solicitados, apontando para uma tendência que denominamos de Indefinida. As respostas dadas pelos entrevistados representantes dessa tendência pouco explicitaram suas compreensões em relação a desenvolvimento sustentável, meio ambiente, educação e/ou EA. Algumas repostas são confusas, outros se limitam à repetição de palavras ou jargões, o que nos mostra que possivelmente esses professores pouco refletiram sobre a incorporação da temática ambiental ao ensino formal. Um grupo de professores trouxe nas suas falas elementos que indicam uma tendência Ingênua-romântica. Embora os professores reunidos nessa tendência se mostrem preocupados com os caminhos que a crise ambiental nos levará e que demonstrem imprimir nas suas práticas de ensino essa preocupação, sua postura a-histórica os impede de considerar as dimensões políticas, sociais, econômicas e culturais nas compreensões que tem de EA. Consideram a espécie humana genericamente como culpada das degradações ambientais e mantêm uma relação romântica com a natureza, buscando a volta do equilíbrio perdido, revelando-se, assim, como uma postura ingênua diante da problemática ambiental. Embora alguns professores dessa tendência tenham práticas que procuram romper com as práticas tradicionais de EA, a maioria aposta na conscientização e sensibilização dos alunos. Essas três tendências, de uma maneira geral, estão alinhadas a uma educação que busca adaptar e ajustar o indivíduo ao modelo social vigente - dentro de uma concepção de uma educação bancária (FREIRE, 2005) ou uma educação utilitária (SATO, 1997). Finalmente, uma minoria dos entrevistados conseguiu expressar nas suas respostas elementos que a diferencia dos demais entrevistados e, assim, foi reunida na tendência que chamamos de Questionadora. Traz uma visão mais crítica e elementos políticos e históricos para a discussão da EA. Considera as relações sociais nas suas definições de meio ambiente e reconhece o potencial da educação nas transformações sociais, mas não numa postura salvadora. Sabe também que a EA ao ser incorporada ao ensino formal precisa ser trabalhada transversalmente e interdisciplinarmente, mas, diante das dificuldades impostas pela estrutura escolar, pouco das suas teorias são refletidas na sua prática de ensino relacionada a EA.

\subsection{A incorporação da Educação Ambiental na escola de ensino fundamental}

Nessa terceira e última parte das discussões dos resultados, pretendemos compreender de que modo a EA vem sendo incorporada nas práticas de ensino escolar. Nas duas primeiras partes desse trabalho, levantamos o perfil dos professores que trabalham com EA, suas motivações para se envolver e desenvolver trabalhos com a temática ambiental e como tem sido sua informação e 
formação em relação à EA, assim como também trouxemos as tendências de EA que co-existem no ensino fundamental. Nesse momento da análise, nossa atenção é justamente abordar e refletir as maneiras pelas quais a EA adentra-se no currículo escolar. Para tanto, iremos discutir, a partir das falas dos entrevistados, o modo como a EA vem sendo tratada nas disciplinas, quais os recursos utilizados nas atividades, quais são as dificuldades encontradas pelos professores ao inserirem a problemática ambiental nas suas aulas e, finalmente, discutir o porquê de a idéia de criar uma disciplina de EA ainda é tão presente na escola, mesmo que essa tenha sido uma discussão há muito tempo concluída nas conferências internacionais de EA, constando, inclusive, sua abordagem interdisciplinar nas leis nacionais.

\subsubsection{A Educação Ambiental na prática dos professores: a incorporação da temática ambiental no currículo escolar}

Durante as entrevistas foi solicitado aos professores que dissessem a maneira pela qual tratam a EA na sala de aula, a saber: 1) Você trata da temática ambiental em sala de aula? De que maneira? Em quais turmas? Por quê? 2) Quais são os conteúdos da sua disciplina que você relaciona a EA? São ocasiões pontuais ou desenvolvidas ao longo do ano letivo? 3) Você já participou e/ou desenvolveu algum projeto de EA? Se sim: título do projeto, responsáveis (orientadores), instituição pertencente, ano, tempo de duração, temática. Qual foi o objetivo do projeto? Qual é sua avaliação? Qual a sua participação na elaboração destes projetos?

As falas dos entrevistados sobre as questões referentes às práticas de EA nos permitiram identificar as maneiras como a temática ambiental vem sendo incorporada no ensino formal. Os professores entrevistados buscam incorporar a temática ambiental nos conteúdos programados de suas disciplinas. Nas escolas visitadas, notamos também que o desenvolvimento de projetos com temas que permeiam a EA é uma prática que vem acontecendo com intensa freqüência. Também pudemos levantar outras atividades que são desenvolvidas de maneiras mais pontuais pelos professores ao abordar a EA no ensino fundamental, como feiras de Ciência, excursões ou em datas comemorativas. 


\subsubsection{Atividades extracurriculares pontuais}

Os professores entrevistados aproveitam oportunidades que surgem no dia a dia ou em ocasiões programadas da escola para desenvolver atividades que se relacionam com EA, como as datas comemorativas, as feiras de Ciências ou feiras ecológicas, as notícias que saem na mídia sobre a temática ambiental e as posturas de professores e alunos na sala de aula.

As datas comemorativas são aproveitadas por alguns professores como um momento de realização de algumas atividades com seus alunos, como o Dia da Água ou Semana do Meio Ambiente. A professora de Ciências da Escola Particular B é uma das entrevistadas que procura aproveitar essas datas comemorativas:

“(...) esse ano na semana do meio ambiente eu também tratei alguns assuntos com eles. Então, foi assim muito rápido. Não foi nada assim fechado”.

Essa mesma professora procura introduzir até nos momentos de avaliações questões referentes à problemática ambiental:

“(...) em algumas provas em ponho questões relacionadas ao dia-a-dia, ao meio ambiente. $\mathrm{Na} 5^{a}$ serie mesmo eu coloquei sobre gastos de energia. Que prejuizo pode causar? (...) Teve uma outra questão que eu falei na prova sobre os esgotos industriais e domésticos. Que atitude poderia ser tomada? Uma vez ou outro eu sempre estou colocando uma coisinha ali porque é uma coisa do dia-a-dia, tem que ser tratada sempre e eles têm que ter consciência do que está acontecendo no mundo" (professora de Ciências da Escola Particular $B$ e coordenadora da Escola Estadual J).

Outros professores utilizam notícias que estão presentes na mídia para trabalhar com questões ambientais atuais. A professora de Geografia da Escola Estadual H procura fazer essa ponte entre a atualidade e a escola através dos meios de comunicações:

“(...) quando a gente está trabalhando geografia às vezes surgem alguns assuntos, quando aconteceu o tsunami. Alguma coisa que acontece na parte do meio ambiente, algum problema ambiental. Então eles trazem para sala de aula, ai eu até paro o conteúdo e a gente conversa (...) o meio ambiente esta todo dia, no dia-a-dia.(...) quando alguém traz um problema eu dou esta abertura". 
Outros professores tratam a EA através do comportamento de alunos e professores na sala de aula. A professora de Ciências da Escola Estadual A vê na postura de seus alunos em relação à limpeza da sala de aula uma maneira de estar discutindo com eles a questão ambiental:

"Eu falo para eles que ambiente não é só o rio, uma mata. Dentro da sala de aula mesmo, jogar papel no chão. (...) Para que ele vai jogar papel no chão se tem o lixo? Isto é uma coisa que todo o dia eu estou batendo nesta tecla: olha o lixo, por que jogar no chão se tem o lixo? Cuide desta carteira, por que riscar? Vocês não ficam a maior parte do tempo aqui? (...) E na última aula a gente pede para eles alinharem as carteiras, se tiver papel em volta deles juntar e jogar no lixo".

A coordenadora e professora de Geografia da Escola Particular D também aproveita essas oportunidades surgidas no dia a dia da sala de aula através de exemplos dados pelos próprios professores em relação a sua conduta na sala:

"Saiu da sala apaga a luz, desliga o ventilador. Então eles já sabem... parece que eles olham já esperando a atitude do professor (...). Melhorou bastante a questão do lixo na sala de aula".

Todos esses são momentos corriqueiros existentes na escola ou na vida de professores e alunos e são aproveitados para que seja introduzida a EA no ensino escolar. Claro que são momentos que devem ser usados para enriquecer as atividades de EA. Mas, o caráter descontextualizado, improvisado e até mesmo imediatista dessas atividades sugerem que tenham pouco efeito na incorporação da problemática ambiental no currículo escolar.

\subsubsection{Dentro dos conteúdos programados das disciplinas}

Ao serem questionados de que maneiras tratam a EA nas suas disciplinas, pudemos notar que para os professores de Ciências e Geografia a inserção de temáticas ambientais nas suas aulas ocorre de maneira mais habitual do que para os professores responsáveis pelas disciplinas ditas não “ambientais”, como Artes, Matemática e Português. 


\subsection{Ciências e Geografia}

As falas dos professores de Ciências e Geografia nos permitiram chegar a três tipos de respostas, a saber: aqueles professores que enxergam uma ligação muito estreita dos conteúdos das suas disciplinas com EA, aqueles professores que acreditam que alguns conteúdos das suas disciplinas podem ser ligados a EA e, por último, aqueles professores que encontram certa dificuldade em ligar os conteúdos da sua disciplina à temática ambiental.

No primeiro grupo, dos que acreditam que exista uma grande integração da sua disciplina com temas ligados à EA, temos respostas do tipo:

"Ciência é tudo. Não tem como. Desde quando você está na $5^{a}$ series você vai estudar a água, ar, você vai falar de poluição e poluição é educação ambiental (...) você vai falar da dengue, você vai falar do ambiente. Na ciência tudo está relacionado, não tem como fugir da educação ambiental" (professora de Ciências da Escola Estadual H).

"Estão intimamente ligados, você vai falar da bacia (...), do uso do solo. Então, a questão ambiental em geografia é muito constante. Você vai tratar da paisagem, vai tratar do lugar, os aspectos ambientais e seus componentes..." (professor de Geografia da Escola Estadual C).

As falas desses professores (três professores de Ciências e três professores de Geografia) nos permitem entender porque ainda hoje é tão comum no ensino formal que a EA fique sob a responsabilidade quase exclusiva das disciplinas de Ciências e Geografia. Ora, ao entender que os conteúdos das suas disciplinas estão "inteiramente relacionados" ou "intimamente ligados" com EA, é quase que automático incluí-la ao currículo escolar através dessas disciplinas. Essa generalização extrema dos temas das disciplinas de Ciências e Geografia também foi encontrada por Carvalho (1989) na sua pesquisa. Para este autor, esses professores, ao conectarem suas disciplinas quase que inteiramente à EA, anulam-na e impossibilitam que os aspectos característicos e pertinentes à problemática ambiental possam ser discutidos por se perderem nessa generalização. De fato, a questão ambiental precisa ser compreendida na sua totalidade (social, cultural, política, econômica e biológica), porém, ao não explicitar como determinado tópico do conteúdo pode estar relacionado com a dimensão ambiental, o professor deixa de contextualizar a problemática ambiental e esta acaba perdendo-se nos conteúdos das disciplinas. 
O segundo tipo de respostas, dos professores que relacionam temas da EA com os conteúdos programados sempre que o tópico a ser estudado permite essa ligação, encontramos a maioria dos professores de Ciências (13) entrevistados e dois professores de Geografia:

"Trato na classe com eles assuntos como queimada, poluição... poluição sonora (...) já falei com eles dos rios, da contaminação de água” (professora de Ciências da Escola Particular E).

"De preservação (...) do meio ambiente, efeito estufa, de sistemas, de toda esta parte... de mata ciliar, de bacias" (professora de geografia da Escola Estadual $\mathrm{H})$.

Nesse tipo de resposta, encontramos professores, dois dos professores de Ciências e uma de Geografia, que mostraram uma dependência com o livro didático. Assim, para esses entrevistados, a EA é trabalhada sempre que é abordado pelo livro didático:

"Trato assim de acordo com que está sendo exposto no conteúdo, de acordo com o conteúdo do livro eu procuro dar uma falada sobre alguma coisa" (professora de Ciências da Escola Particular F).

O terceiro e último tipo de grupo de respostas é formado por professores que sentem dificuldades de relacionar a EA com os conteúdos da sua disciplina. Fazem parte desse grupo somente dois professores de Geografia:

“(...) eles tiraram muita coisa que era de geografia e colocaram em ciências. $O$ conteúdo de $5^{a}$ a $8^{a}$ séries é sempre ciências que trabalha mais as questões ambientais. Para geografia sobrou muita coisa de (...) urbano. Como nós sempre cuidamos da questão da água e agora nós temos que cuidar mais das questões urbanas" (professora de Geografia da Escola Estadual J).

“(...) às vezes os alunos perguntam o que a água tem a ver com geografia... Tem que falar dos rios... da questão ambiental... da problemática da falta da água. É um negócio que está ocorrendo no mundo todo. Se não cuidar vai faltar" (professor de Geografia da Escola Estadual F).

A primeira professora mostra claramente que a sua dificuldade de estar relacionando a EA aos conteúdos de Geografia está no fato de ela não entender que meio ambiente refere-se, além da natureza, à sociedade também. Ela ligava a temática ambiental, provavelmente, somente aos seus 
aspectos biológicos, e agora, que tem que trabalhar com temas mais urbanos, não consegue fazer essa ligação. O segundo professor alega que são os alunos que sentem dificuldade de relacionar as temáticas ambientais com a sua disciplina. Ora, é da responsabilidade do professor estar fazendo essa ligação. Talvez essa seja uma boa oportunidade de o professor estar mostrando para seus alunos que a questão ambiental não se limita apenas aos aspectos biológicos e, juntamente com os alunos, investigar como os aspectos sociais, econômicos, políticos e culturais afetam e influênciam a problemática ambiental.

\subsection{Conteúdos que os professores de Ciências e Geografia relacionam com Educação Ambiental}

Durante as entrevistas realizadas com os professores de Ciências e de Geografia, foi solicitado que eles especificassem quais tópicos dentro dos conteúdos programados das suas disciplinas no ensino fundamental eles relacionavam com EA. A tabela 4 reúne esses conteúdos citados pelos professores de Ciências e Geografia, e as freqüências com que foram mencionadas.

Entre os entrevistados, temos oito, seis de Ciências e dois de Geografia, que, mesmo estimulados a detalhar mais, restringiram-se a respostas superficiais ou até mesmo não especificaram quais conteúdos estão ligados a EA.

Diante das respostas dos professores podemos levantar dois aspectos. O primeiro é com relação à facilidade dos professores em relacionar os conteúdos das séries iniciais do ensino fundamental com a EA. A professora de Ciências, da Escola Particular C, nos mostra como essa ligação é estreita:

“De $5^{a}$ série dá bem para relacionar. Porque aprende água, poluição. Então, é o tempo todo. De $6^{a}$, que é a parte de seres vivos e trabalha mais a parte ambiental de conservação e habitat dos animais, cadeia. Ai a parte da $7^{a}$ série, que é de corpo humano, eu acho que é até educação ambiental, mas é mais a parte de educação sexual... não deixa de ser educação ambiental também. Ai de $8^{a}$ vai complicar porque já começa física... tem um pouco de química também”. 
Tabela 4 - Conteúdos do currículo que os professores de Ciências e Geografia relacionam a EA, em ordem alfabética Legenda: C (Ciências) e G (Geografia)

\begin{tabular}{|c|c|c|c|c|c|c|c|}
\hline Conteúdos & C & G & Total & Conteúdos & $\mathbf{C}$ & G & Total \\
\hline $\begin{array}{c}\text { Não especificou ou } \\
\text { especificou } \\
\text { superficialmente }\end{array}$ & 6 & 2 & 8 & $\begin{array}{c}\text { Geopolítica } \\
\text { mundial }\end{array}$ & - & 1 & 1 \\
\hline Água & 8 & 2 & 10 & Industrialização & - & 2 & 2 \\
\hline Aquecimento global & 1 & - & 1 & Lixo & 2 & - & 2 \\
\hline Ar & 5 & - & 5 & Lixões & - & 3 & 3 \\
\hline Bacia hidrográfica & - & 2 & 2 & Mata ciliar & 1 & 2 & 3 \\
\hline Biodiversidade & 1 & - & 1 & Meio ambiente & 2 & - & 2 \\
\hline Cadeia alimentar & 1 & - & 1 & Piracema & 1 & - & 1 \\
\hline Cidadania & 1 & - & 1 & Planetas & 1 & - & 1 \\
\hline Clima & - & 2 & 2 & Poluição & 8 & 1 & 9 \\
\hline Conservação & 1 & - & 1 & Preservação & 2 & - & 2 \\
\hline $\begin{array}{l}\text { Consumo/ } \\
\text { consumismo }\end{array}$ & - & 1 & 1 & $\begin{array}{l}\text { Problemática da } \\
\text { cana-de-açúcar }\end{array}$ & 1 & - & 1 \\
\hline Continentes & - & 1 & 1 & Queimadas & 2 & - & 2 \\
\hline Corpo humano & 2 & - & 2 & Química & 1 & - & 1 \\
\hline Dengue & 1 & - & 1 & Reciclagem & 2 & - & 2 \\
\hline Desmatamento & 2 & 2 & 4 & Relevo & - & 2 & 2 \\
\hline Ecologia & 1 & - & 1 & Saúde & 2 & - & 2 \\
\hline Economia & - & 1 & 1 & Seres vivos & 1 & - & 1 \\
\hline Ecossistema & 2 & - & 2 & Solos & - & 2 & 2 \\
\hline Educação sexual & 2 & - & 2 & Tráfico de animais & 1 & - & 1 \\
\hline Efeito estufa & 1 & 2 & 3 & Urbanização & - & 1 & 1 \\
\hline Energia & - & 1 & 1 & Uso racional & 1 & - & 1 \\
\hline Espécies em extinção & 1 & - & 1 & Vegetação & - & 2 & 2 \\
\hline
\end{tabular}


Os conteúdos de Ciências e Geografia das $5^{\mathrm{a}}$ e $6^{\mathrm{a}}$ séries permeiam as questões bióticas e abióticas da natureza. Ao entenderem que a EA se restringe a esses aspectos, são nessas séries do ensino fundamental que os professores darão uma ênfase maior em relação à problemática ambiental.

A segunda questão é a predominância de aspectos físicos, químicos e biológicos nos conteúdos que são relacionados pelos entrevistados. Vários autores (BRÜGGER, 1998; CASCINO, 1998; GRÜN, 1996; LIMA, 1999; MATSUSHIMA, 1991, REIGOTA, 1994; entre outros) já apontavam uma predominância nos trabalhos de EA dos aspectos biológicos e técnicos em detrimento dos aspectos políticos, sociais, econômicos, éticos e culturais.

A tabela 4 revela que alguns dos tópicos levantados na presente pesquisa são pertencentes tradicionalmente aos conteúdos de Ciências e Geografia, como relevo, cadeia alimentar, continentes, ecossistemas, corpo humano, ar, água, poluição. Outros assuntos são aqueles que, há algum tempo, foram incluídos na pauta da discussão ecológica e são veiculados amplamente pela mídia, como aquecimento global, desmatamento, tráfico de animais, efeito estufa, conservação, preservação, reciclagem, lixo e dengue.

Para Paula Brügger (1998), a exclusão das dimensões políticas, sociais, econômicas, éticos e culturais e a ênfase biológica e técnica dada à problemática ambiental fazem surgir um adestramento ambiental. Para a autora, o "não-questionamento do porquê histórico das relações entre sociedade e natureza favorece (...) o surgimento de um processo técnico de instrução, semelhante a um adestramento" (p. 63). De fato, dos 43 conteúdos citados pelos professores de Ciências e Geografia, apenas oito, procuram de alguma forma abordar a relação indivíduo-sociedade-natureza, ao tratar da temática ambiental, a saber: geopolítica mundial, industrialização, cidadania, consumo/consumismo, problemática da cana-de-açúcar, economia, urbanização e uso racional. Se esses conteúdos, ao serem tratados nas aulas, foram além de uma abordagem biológica e técnica e incluíram na sua discussão suas relações com as questões sociais, econômicas e políticas, esses professores estarão fugindo do lugar comum que parece predominar no ensino formal ao tratar da problemática ambiental. 


\subsection{Conteúdos que os professores de Artes, Matemática e Português relacionam com Educação Ambiental}

Os professores entrevistados, responsáveis pelas disciplinas de Artes, Matemática e de Português mostraram dificuldade em relacionar os conteúdos das suas disciplinas com EA. Vale lembrar aqui que, entre os entrevistados, tivemos dois que lecionam Ciências e Matemática e uma que leciona Geografia e História em suas escolas. Mas somente a professora da Escola Estadual A já desenvolveu trabalhos nas duas disciplinas pelas quais é responsável. Os outros dois professores só tratam de temas relacionados com EA dentro da disciplina de Ciências e Geografia.

Entre as professoras de Artes entrevistadas, a da Escola Estadual C, estava para iniciar sua participação em um projeto e até então nunca havia participado de qualquer outra atividade relacionada à EA. Já a professora da Escola Particular C procura trabalhar questões ambientais nas suas aulas sempre que lhe é permitido. Na sua fala podemos observar:

“(...) eu tento colocar materiais recicláveis dentro das esculturas (...) Como a gente vai fazer essa PET virar um a coisa artística de verdade. Não olhar e falar: ah, isso é um rolinho de papel higiennico. Vamos transformar. (...) Pela apostila a gente deveria fazer com massinha de modelar ou argila. Ai eu ensinei a fazer a massa de papel machê, reciclando o papel da escola mesmo (...) Na oficina de teatro, o que dá para reutilizar (...) sempre tratar a questão do meio ambiente (...) que eles fazem parte do meio ambiente”.

Entre os professores de Matemática, a EA é normalmente tratada através de trabalhos estatísticos, como construções de tabelas e gráficos, usando dados extraídos de textos que abordam questões ambientais. Assim, esses professores usam exemplos ambientais do cotidiano dos alunos para explicar os conteúdos de Matemática. As falas das professoras nos expõem esse fato:

"Se eu der raiz quadrada (...) Dai eu conto a história da raiz quadrada (...) um matemático mediu uma raiz (...) Então, envolvo um pouco a natureza... com questões de plantas, que neste caso seria a raiz" (professora de Matemática da Escola Estadual C).

"Com dados. Mais só com dados estatísticos mesmo... gráficos, construção de tabelas (...) Geralmente a gente trabalha com texto também. (...) Sobre poluição mundial, sobre prejuizos... destruição da camada de ozônio, por exemplo. (...) A grande produção de lixo no mundo (...) Ás vezes fica só no texto mesmo. Na discussão do texto e a gente não monta dado nenhum... Dai eu acho que ajuda a abrir a cabeça" (professora de Ciências e Matemática da Escola Estadual A). 
No final da segunda fala, a professora revela que às vezes as atividades ficam centradas na discussão do texto com os alunos. Talvez o fato de essa professora também ser responsável pela disciplina de ciências possa ajudá-la a ter essa liberdade e, assim, "abrir a cabeça" de seus alunos para a problemática ambiental.

O professor de Matemática da Escola Estadual I também é responsável pela disciplina de Informática na escola, e, igualmente, utiliza as oportunidades que surgem para tratar de temas ambientais:

"O objetivo é ensinar a pesquisar. O aluno torna-se um pesquisador. Então, um pesquisador do meio ambiente. Eu passei um trabalho de reciclagem para eles, de reciclagem de sólidos. E cada um pegou, desde papel, plásticos, entulhos, orgânico... Então, eles estão fazendo um trabalho pesquisando na Internet, salvando no Word e depois vão montar uma apresentação no PowerPoint. No Excel uma tabela, e no PowerPoint os slides".

Esse professor procura ir além dos limites da sua disciplina e estimula o desenvolvimento de atividades de pesquisa com seus alunos para que eles se tornem pesquisadores.

A professora de Português da Escola Estadual K procura tratar da temática ambiental sempre que é possível:

"Eu trato sempre que eu posso. Sempre que eu tenho oportunidade. No começo do ano a gente trabalha com os valores humanos e ai entra a questão do respeito e, por pertencemos ao gênero humano, a gente tem que cuidar do planeta e isso é colocado para eles. A gente tem que cuidar, preservar e cuidar do meio ambiente, que a questão de você se relacionar com o inteiro. Que é o todo. A gente é uma parte disso (...). Porque eu acredito que seja função da escola desenvolver consciência. Então, antes de ser conteudista e preparar o aluno para entrar numa faculdade ou vestibular, eu acho que ele tem que ser preparado para a vida. E transformar informação em conhecimento, para a vida dele. E dentro dessa proposta de desenvolver consciência, consciência política, que eu acho que tem que desenvolver porque política não é um ato de ir no dia da eleição para urna e escolher o representante, politica é o que a gente faz no nosso cotidiano, consciência ética, que é a do respeito e consciência ecológica, que é importantíssima".

Mais uma vez, observa-se a tendência de os professores de Ciências, principalmente, e de Geografia em trabalharem assuntos ligados a temáticas ambientais é trazida à tona. Essa idéia de que as disciplinas de Ciências e de Geografia são as mais adequadas para trabalhar com assuntos ambientais é evidenciada pelo fato de as questões ecológicas serem tratadas predominantemente 
pelos seus aspectos técnicos e, portanto, nada mais conveniente do que atribuir a responsabilidade a um professor da área. Para Barcelos (2003), essa é uma maneira de não incluir no estudo da problemática ambiental os seus aspectos históricos, sociais e culturais, é querer "limpar um tema de suas complicações político-ideológicas” (p. 84). Para que o educando tenha uma visão completa, todas as disciplinas escolares devem lhes proporcionar "um enfoque holístico, global e integrado, considerando os vários ângulos e implicações de um mesmo problema” (KRASILCHIK, 1986, p. 1960). Para esta autora, tanto os fatores biológicos, físicos e químicos que permeiam a questão ambiental quanto os sociais, econômicos, políticos e culturais devem ser incluídos pela escola ao incorporarem a EA nas suas práticas de ensino. Embora os professores entrevistados de Artes, Matemática e Português tenham mais dificuldades de estar relacionando os conteúdos das suas disciplinas com EA do que os professores entrevistados de Ciências e Geografia, isso não os impediu de trabalhar com temas ligados à problemática ambiental. Mesmo que muitas vezes isso ocorra de maneira tímida, esse é um envolvimento importante no ensino escolar, que ajuda a acabar com o mito de que somente as disciplinas de Ciências e Geografia são capazes de inserir a EA no currículo escolar. Ora, se é importante que os alunos tenham uma abordagem contextualizada e holística de temas ambientais, para que possam compreendê-los nos seus múltiplos aspectos, nada mais esperado que todos os professores de todas as disciplinas se envolvam e auxiliem seus alunos.

\subsubsection{Os projetos de Educação Ambiental}

As escolas parecem dar preferência em inserir e desenvolver a EA nas práticas de ensino através de projetos. Dos professores entrevistados da rede particular, dois nunca participaram de projetos relacionados com EA. Seis professores estão planejando ou já desenvolveram projetos da própria escola e quatro professores já realizaram projetos em parceiras com outras instituições. $\mathrm{Na}$ rede estadual de ensino, quatro professores entrevistados nunca participaram de qualquer projeto de EA, dezesseis professores estão elaborando ou já desenvolveram projetos da própria escola e treze já participaram ou vão desenvolver projetos em parcerias com outras instituições. Das escolas selecionadas para a pesquisa, apenas a Escola Estadual B e a Escola Particular A declararam que não estavam trabalhando com projetos no momento da visita. 


\subsubsection{Os projetos de Educação Ambiental desenvolvidos pelas escolas}

Durante as visitas realizadas às escolas pudemos, notar duas situações em relação aos projetos que são idealizadas pela direção e/ou professores: um grupo de escolas vem que trabalhando com desenvolvimento de projetos de EA com maior freqüente e um segundo grupo de escolas que trabalha com projetos de EA de uma maneira mais circunstancial e depende de uma situação, ocasião ou motivação de um determinado grupo de pessoas.

No primeiro grupo, temos quatro escolas. São escolas que optaram por trabalhar com projetos dentro da proposta pedagógica, incluídos no planejamento escolar. Porém, é comum que os projetos trabalhem com temas mais variados, não sendo, necessariamente, voltados para EA. É o que acontece na Escola Estadual G que mantém vários projetos, mas no momento da visita não tinha nenhum relacionado à $\mathrm{EA}$ :

"Não temos nenhum especifico de educação ambiental. (...) Agora, tudo tem uma ligação, não é verdade? Então, por exemplo, as crianças nossas que estão como voluntariado lá no Lar Escola. Por exemplo, se eles aprendem sobre lixo, eles vão passar esta informação para as outras crianças. De como cuidar do lixo, do destino que ele deve ter. (...)" (coordenadora da Escola Estadual G).

Às vezes, as atividades do projeto são direcionadas para a EA, como a diretora da Escola Particular E nos relata:

“(..) vários projetos maiores acabam premiando a questão ambiental. Por exemplo, os jogos de outono (...). Jogos de outonos é uma atividade que tem na escola, as crianças são divididas em grupos (...) há muita competição, mas também há muita cooperação (...) Esse ano acabou ficando a Copa (...). Mas teve anos que nós estudamos a questão do ambiente também. Então, depende do ano, depende do momento".

Outras vezes, um tema é escolhido e trabalhado por todas as disciplinas, como é o caso de um projeto da escola relatado pela professora de Ciências e que teve como tema Piracicaba:

"Cada série eu pedi para eles pesquisarem um campo. Na $5^{a}$ série eu pedi para eles pesquisarem tudo relacionado às estações de tratamento de água, esgoto, em relação à matéria que eles têm mesmo. $N a \sigma^{a}$ série os ambientes ecológicos, se a cidade tem uma arborização adequada (...). Tudo voltado para essa parte que eles estão estudando. $\mathrm{Na} 7^{a}$ série mais relacionada à parte de saúde. Na $8^{a}$ série a questão de trânsito (...). E cada matéria trabalhou da sua 
forma. Eu trabalhei assim, a professora de português de outra, a de geografia de outra, mas tudo voltado para o tema Piracicaba" (professora de Ciências da escola particular B).

As escolas desse primeiro grupo também apresentam alguns projetos que são específicos de EA, como horta medicinal, coletas seletivas ou a construção de uma "sucateca". É o que nos disse a coordenadora da escola particular B:

"O último projeto que a gente trabalhou foi justamente "desembalando o planeta”. Seria a gente retirar todas as embalagens que ficam para degradação no meio ambiente e o que a gente poderia estar fazendo".

O restante das escolas que compõem o segundo grupos trabalha eventualmente com projetos relacionados com EA, como construções de hortas escolares e coletas seletivas. A coordenação e/ou professores aproveitam determinadas ocasiões, como datas comemorativas, ou situações, como lixos acumulados na escola, para desenvolver projetos de EA.

A resposta da professora de geografia da Escola Estadual J em relação ao que motivou a escola a desenvolver o projeto de reciclagem é um exemplo:

"É porque a escola tem os latões devidamente coloridos para separação, para a coleta seletiva e de repente ele parou de ser utilizado. Então, foi um consenso da coordenação e direção que eles deveriam voltar a ser novamente utilizados. Para não ser assim (...) sem o colégio saber o que estava acontecendo foi pedido para que se realizasse o projeto".

Já na Escola Particular C, o projeto de reciclagem foi desenvolvido pela vontade da professora de Ciências que teve, posteriormente, um apoio da direção:

“(...) eu queria começar a trabalhar com reciclagem mesmo... eu queria fazer uma oficina de reciclagem com a $5^{a}$ série, mas porque eu estava trabalhando com o tema reciclagem. A diretora me apoiou porque não tinha nada de reciclagem no colégio. Ela já me comprou aquele liquidificador profissional e tal, ai eu já tinha todo o aparato. Eu quis estender para escola. Eu comecei com todas as séries e eu faço todo ano com todas as salas".

Dentro desse segundo grupo, encontramos também aquelas escolas que costumam trabalhar em forma de projetos, mas no momento das entrevistas ou ainda estavam na fase de planejamento foram visitadas no início do primeiro ou do segundo semestre letivo - ou não iriam trabalhar com 
projetos naquele ano. Das escolas que não tinham planos de desenvolver projetos no ano letivo em que se realizou a pesquisa, encontramos uma escola estadual na qual as professoras de Ciências entrevistadas estavam substituindo a professora efetiva; em outra escola estadual, a professora de Ciências entrevistada nunca teve experiências com projetos e estava adaptando-se no seu primeiro ano de trabalho; e uma escola particular, que pensava juntamente com os professores qual era a melhor maneira de estar trabalhando com a EA. Porém, nas escolas que ainda estavam em fase de planejamento de suas atividades corria-se o risco de não ter esses projetos desenvolvidos. Fato que é denunciado na fala da professora de Português da Escola Estadual K:

“(...) no papel é uma maravilha. Porque ele aceita tudo e porque também o papel é colocado lá: olha, nós fizemos o projeto, está aqui escrito; mas se ele foi desenvolvido ninguém vem constatar. O problema da escola pública é esse. $O$ nosso gestor está muito distante, então não tem alguém que venha avaliar, verificar, se tem recurso se não tem, o que quê precisa, isso não existe”.

\subsubsection{Os projetos de Educação Ambiental desenvolvidos em parcerias/orientação externa}

Das dezessete escolas que participaram da pesquisa, treze já trabalharam ou atualmente trabalham com projetos que são desenvolvidos em parceria com alguma instituição externa, sendo que, dessas trezes, cinco são particulares e oito são estaduais. Somente quatro das escolas visitadas nunca trabalharam com projetos em parcerias, sendo uma particular e três estaduais. As instituições citadas como parceiras em projetos pelos entrevistados foram a empresa Belgo-Mineira, a empresa Votorantim Celulose e Papel (VCP), a empresa Tetra Pak e as empresas estatais Semae e CPFL. O MEC, o MMA e a DE foram as instituições públicas citadas pelos professores. 


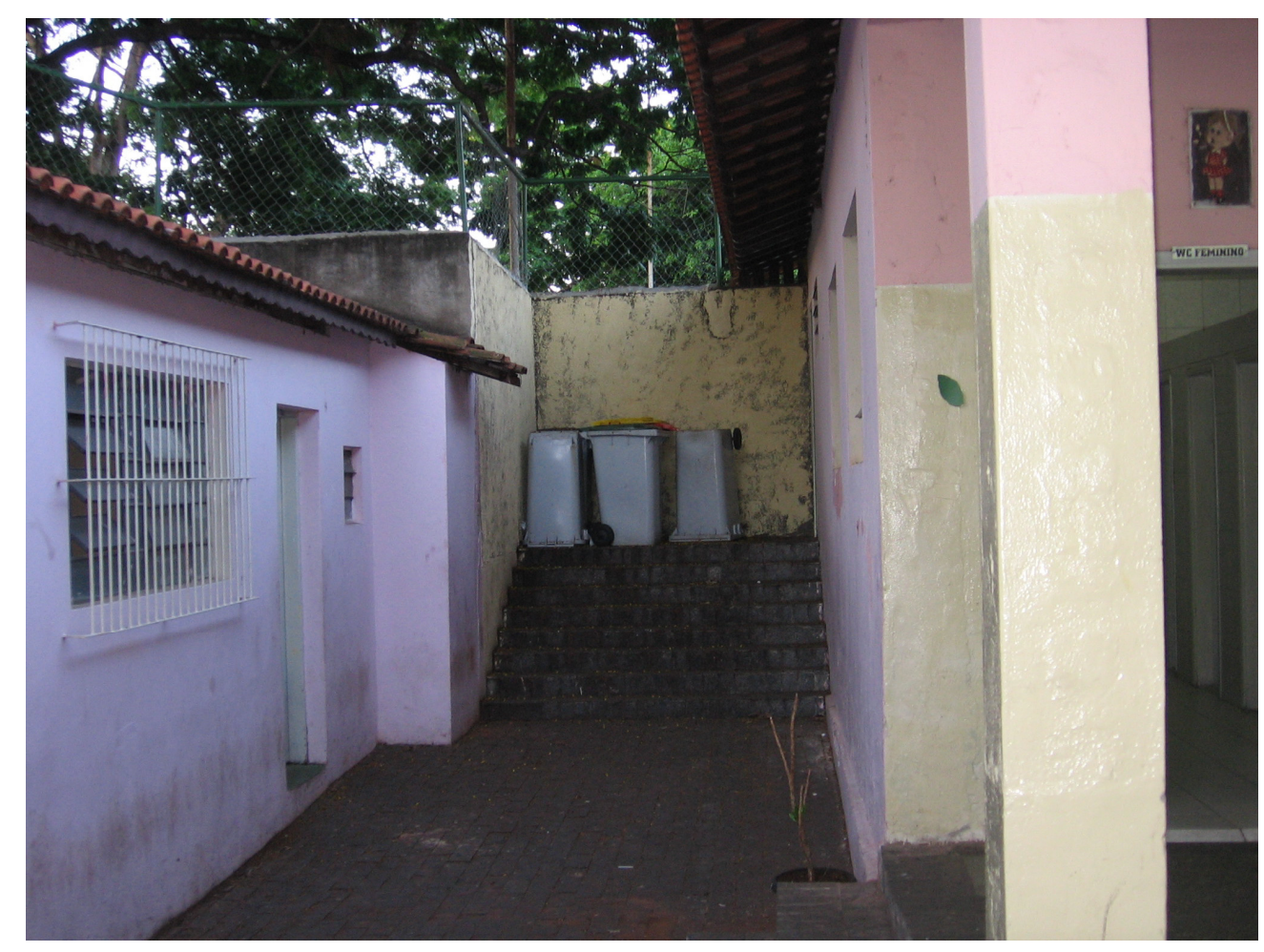

Figura 14 - Coletores de lixo seletivos de uma escola estadual

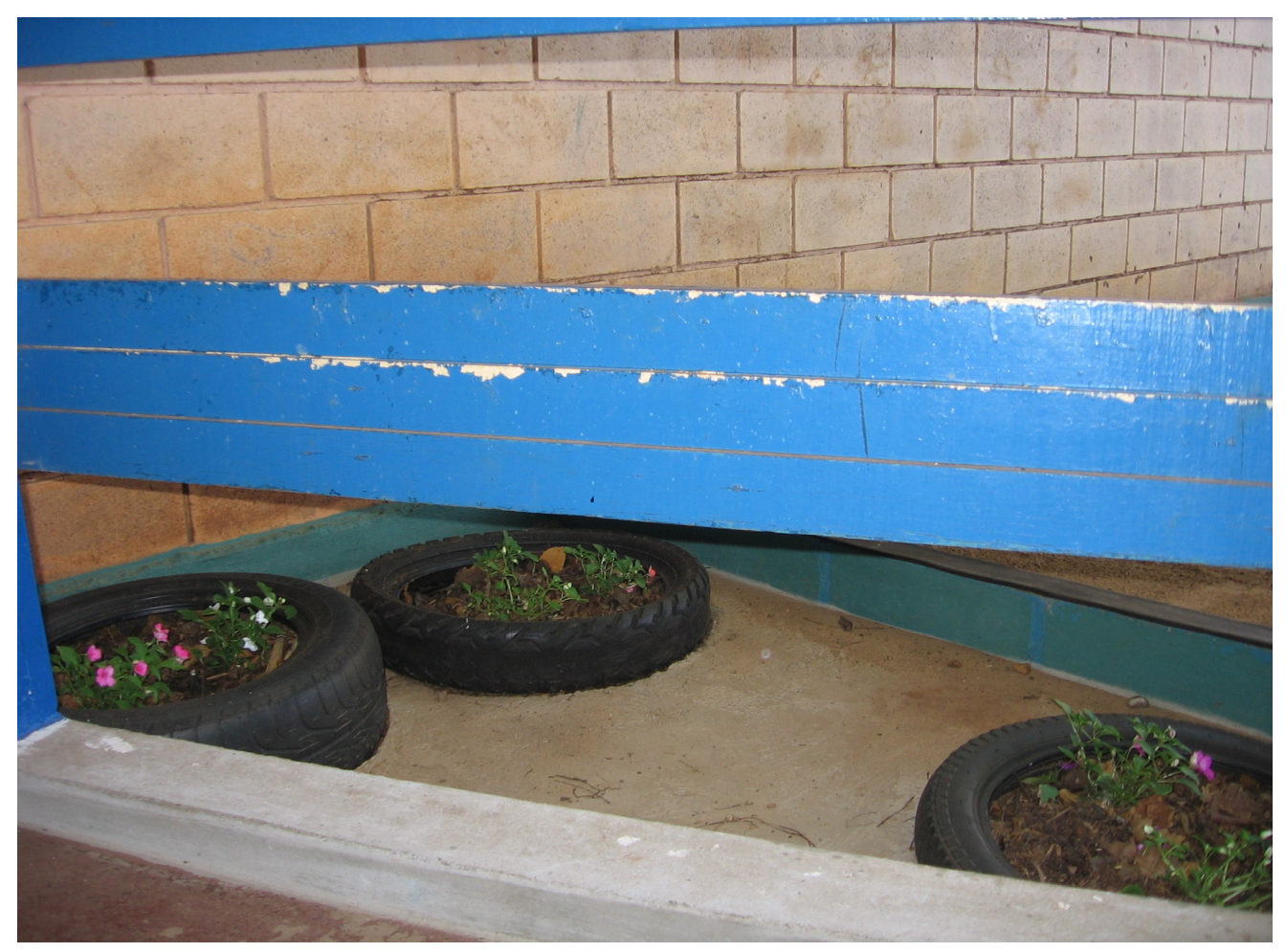

Figura 15 - Pneus reutilizados como canteiros de flores em uma escola particular 
A DE possui vários projetos, como o do "Tabagismo" - de precaução contra o fumo, que estavam sendo desenvolvidos por várias escolas visitadas. Porém, parte dos projetos acaba sendo destinada somente para os professores de Ciências. O projeto de construção da Agenda 21 da escola, por exemplo, que deveria ter um caráter transversal, acaba também tendo um tratamento fragmentado e disciplinar, como nos descreve a professora de Ciências da Escola Estadual E:

"Comecei a desenvolver com a ajuda de alguns professores, mas depois acabou ficando só para mim. Eu acabei tendo que desenvolver sozinha. A gente começa numa turma e depois vai perdendo um pouco. Quando chegou no final do ano eu tava sozinha trabalhando (...) se eu estivesse lá queria dar continuidade. Mas infelizmente... no Estado é meio complicado. Eu fui removida para cá, então não sei como está lá. Aqui eu tenho que começar do zero porque este projeto não teve aqui no ano passado".

Alguns projetos entram nas escolas através da DE, como de reciclagem da Tetra Pak e o da “Água Doce” do Semae. Para a rede estadual é importante que esses projetos cheguem à escola através da DE, a fim de que os professores tenham condições de participar.

O MEC foi citado somente pela Escola Particular C como parceiro no projeto "Com-Vida", do próprio MEC. O objetivo do projeto é a criação de um conselho de jovens e da Agenda 21 na escola, como um meio de organização dos estudantes. Esse conselho, que juntamente com outras organizações escolares como grêmio estudantil e associação de pais e mestres, vai criar um espaço destinado ao meio ambiente, e, assim, trazer a EA para o ensino escolar. A professora de Artes relata como o projeto desdobrou-se em outras iniciativas e como os alunos assumiram o seu comando:

“(...) a gente participou da conferência nacional de meio ambiente, fomos escolhidos, teve um representante nosso lá em Brasilia que foi representar a região de Piracicaba (...) Com a volta dele a gente ampliou o "Com-Vida” (...). A gente ampliou o número de pessoas mesmo, das participações e os projetos da "Com-Vida". Tem o projeto de reciclagem de papel da escola, a gente tem o projeto das latinhas - a escola já tinha a grade de latinhas, mas por não ter uma assistência de alunos mesmo, de cobrança "tem a grade, não precisa jogar a latinha lá", ela era subutilizada (...) e além da reciclagem, fazer a reutilização também do papel. (...) E o foco na realidade deles foi a questão étnico-racial. Tratar do homem na ambiente em várias etnias diferentes. Então, a feira de ciencias que a gente fez, e agora a gente vai levar para outras escolas (...). O que eu achei legal e que eu sempre cobrei deles é que o projeto não pode ser só meu e $d a$ [professora de ciências] (...) que é importante que o "Com-Vida" seja deles. Eu ajudo a coordenar, mas tem que vir de vocês. E ai eles passaram a tomar rédea das coisas mesmo. Então, a gente chega lá e eles já estão com projetos 
novos (...). Isso me deixa muito feliz. Eu tenho a impressão que se eu for embora amanhã não vai morrer”.

Nenhuma outra escola selecionada para a pesquisa declarou ter desenvolvidos projetos de EA sob a orientação do MEC/MMA. Assim, tal como acontece com a produção teórica produzida por essas instituições públicas em relação à EA, muitas das iniciativas práticas também demonstram dificuldades para serem introduzidas nas escolas, especialmente no que se refere à rede particular de ensino. De fato, o projeto "Com-Vida" foi o primeiro projeto que a Escola Particular C desenvolveu juntamente com uma instituição externa. A professora de Artes não sabia dizer se os projetos não chegam à escola ou, quando chegam, se ficam presos com a direção.

As empresas, por outro lado, apresentam uma entrada muito mais ampla nas escolas. De fato, os materiais didáticos, as capacitações para os professores e apoio estrutural, como ônibus para excursões, tornam-se um subsídio e atrativo oferecido pelas empresas para os projetos direcionados à EA nas escolas. Dentre as empresas mencionadas pelos professores, a unidade da Belgo-Mineira em Piracicaba e o Semae promovem nas escolas particulares e públicas da cidade, há muito tempo, trabalhos voltados para a problemática ambiental. Das escolas que foram selecionadas para a pesquisa, seis participam ou já participaram do projeto da Belgo-Mineira, sendo duas escolas particulares e quatro estaduais. Em relação ao projeto do Semae, temos três escolas particulares e cinco estaduais, totalizando oito escolas.

A empresa Belgo mantém dois projetos de EA, o Circuito Ambiental e Prêmio BelgoArcelor Brasil de Meio Ambiente. O Prêmio Belgo-Arcelor Brasil de Meio Ambiente foi criado em 1992, destinado aos filhos de empregados da empresa e ás escolas do ensino fundamental das redes públicas e particulares das cidades onde o Grupo Belgo tem suas unidades instaladas. O tema do projeto a cada ano é variado e são distribuídas para as escolas participantes apostilas orientadoras para os professores e cartilhas para os alunos. Os professores recebem uma capacitação que serve para prepará-los para o tema escolhido naquele ano. Os alunos produzem desenhos e redação que irão concorrer com todos os participantes do projeto:

"Eles primeiro dão uma capacitação para a gente. Eles explicam sobre o tema que eles vão querer naquele ano e dai a gente desenvolve com os alunos. Existe toda uma preparação" (professora de Ciências da Escola Particular B). 
O Semae também tem uma relação intensa com as escolas da cidade e mantém um programa de EA direcionado para as escolas. Os projetos sempre estão relacionados com o tema água:

“(...) nas excursões, a gente vai conhecer a nascente do rio Piracicaba, depois do rio Corumbatai e paralelamente a gente vai desenvolvendo com os alunos. Os alunos vão até o tratamento de água, tratamento de esgoto. Então, a gente vai trabalhando a parte de conscientização, a parte de preservação do meio" (professora de Ciências da Escola Estadual J).

A empresa Votorantim também mantém um núcleo de EA que, além das capacitações direcionadas para os professores, também mantém atividades voltadas para alunos. A empresa foi citada como parceira por duas escolas estaduais. A coordenadora da Escola Estadual G nos conta como a empresa realiza esses trabalhos:

"Temos uma classe da $5^{a}$ A que está visitando a Votorantin, que é um núcleo de educação ambiental e eles fazem este trabalho lá. Lá tem os monitores, fazem as dinâmicas, têm palestras, conhecem a firma, a produção de papel. A questão do lixo é tratada. (...). Eles abordam várias outras coisas (...) A questão das matas, as árvores que são plantadas (...) É um trabalho de campo mesmo. Porque é diferente, o aluno sai da sala de aula está lá fora conhecendo, andando pela empresa, ouvindo os funcionários. Lá também eles dão uma explicação muito bacana sobre o tratamento de água, o tratamento do esgoto que é feito lá também. (...) antes das crianças irem visitar, a empresa já veio aqui, já falou do objetivo do trabalho. Então, nós trabalhamos antes, durante e depois, tem o produto final. Eles fazem desenhos sobre o assunto, redação e fica exposto lá" .

A fala da coordenadora nos revela que nesse caso não só o professor não participa da elaboração do projeto da empresa como também não tem participação em nenhuma etapa da visita à empresa. De fato, tentamos entrevistar uma das professoras que tinha participado da visita da $5^{\text {a }}$ série à empresa, mas ela nos disse que nunca participou de projeto de EA e que estava somente acompanhando os alunos na visita. Provavelmente para a maioria dos alunos, assim como para essa professora, a visita à empresa não passou de uma atividade de recreação.

A empresa Tetra Pak também mantém e promove projeto de EA, chamado projeto Cultura Ambiental Nas Escolas e foi citada por duas escolas estaduais. A empresa oferece um Kit de material didático às escolas que participam do projeto, contendo uma cartilha "A Embalagem e o Ambiente" para alunos, um caderno do professor "Meio Ambiente, Cidadania e Educação", o vídeo 
"Quixote Reciclado", um folheto "Faça o seu papel!" e um pôster "Ciclos de Vida das Embalagens". Após participar de uma videoconferência cada professor desenvolveu seu trabalho da maneira que achou mais adequado. Assim, a professora de Ciências da Escola Estadual B passou o vídeo nas $5^{\text {a }}$ até às $8^{\mathrm{a}}$ séries e promoveu uma discussão com os alunos durante suas aulas. Já os professores de Geografia e Matemática da Escola Estadual C utilizaram esses materiais didáticos para acrescentar ao projeto de reciclagem que foi por eles elaborado.

A CPFL foi citada apenas pela professora de Ciências da Escola Estadual A. A empresa mantém dois programas nas escolas: o PROCEL Nas Escolas e o Agente Mirim de Combate ao Desperdício de Energia Elétrica. O PROCEL Nas Escolas é um projeto que capacita os professores das redes pública e particular no combate ao desperdício de energia elétrica e conscientiza da importância dos recursos energéticos renováveis e não renováveis. A empresa produz e distribui para as escolas participantes o livro para o professor, os livros para os alunos, livro da biblioteca, jogos e vídeos. A professora desenvolveu o projeto à época em que o país passava pela crise de energia elétrica. Ela participou enquanto professora de Matemática.

Embora existam facilidades oferecidas pelas parcerias com as escolas no desenvolvimento de projetos, alguns dos professores entrevistados mostraram ter uma postura crítica em relação às instituições parceiras. Para a professora de Ciências da Escola Estadual F, a DE impõe os projetos para as escolas desenvolverem, sem que elas possam participar ativamente da sua elaboração:

“(...) às vezes eles vem com determinados projetos de lá de cima, impostos que não são construidos dentro da escola. Isto não funciona. Eu acho que o corpo docente deveria estar envolvido e montando trabalhos com educação ambiental ou qualquer trabalho multidisciplinar que você precise desenvolver dentro da escola. Não adianta vir com projetos prontos de lá. E você tentar na marra... Eu não acredito nesta linha de trabalho".

Alguns entrevistados observam a contradição da empresa ao estar desenvolvendo projetos de EA ao mesmo tempo em que polui a cidade. Como é o caso da professora de Ciências da Escola Estadual J ao se referir ao Semae:

"Questionamos porque a gente trabalha com os alunos, conscientiza os alunos, mas os alunos vêm que no dia a dia nada disso está sendo feito. Você fala de tratamento de esgoto, mas a cidade não tem tratamento de esgoto suficiente, não atende toda a população. Você fala da poluição do rio e as usinas continuam poluindo, você fala da eutrofização, mas eles vão ao rio e estão vendo". 
E outros entrevistados se mostraram críticos em relação à falta de criatividade desses projetos, como na fala da professora de Ciências da Escola Estadual A:

“(...) Tem não sei quantos anos que a Belgo trabalha e é sempre a mesma coisa, sempre o mesmo livrinho, sempre as mesmas historinhas (...) Os prêmios são os mesmo e eu acho que os alunos não se interessam muito (...)".

Já o professor de Geografia da Escola Estadual $\mathrm{F}$ faz critica à falta de compromisso da empresa com os projetos que propõe às escolas. Ele deixou de participar depois que se sentiu prejudicado:

“(...) no meio do caminho você fica sozinho e com o projeto já em andamento, aí você não pode nem parar o projeto e coça a cabeça, queima os neurônios para continuar. Porque o ano passado simplesmente o Semae deixou largado... Começou com tudo e depois simplesmente morreu o projeto".

Tristão (2004), em sua pesquisa da inserção da EA nas escolas, também observa que muitas vezes a instituição externa passa de parceira para invasora. Para ela, essa resistência por parte de alguns professores mostra que eles desejam ter um papel mais ativo na elaboração dos projetos, pois são os professores que podem "transformar em saber, em reflexão, em ação" (p. 127) as propostas que estão escritas nos projetos. De fato, os projetos chegam prontos nas escolas, os temas já estão escolhidos, os materiais didáticos igualmente chegam prontos e aos professores é oferecida uma capacitação rápida para que sejam orientados a respeito da forma como devem desenvolver as atividades do projeto com seus alunos. Entretanto, observarmos que algumas escolas e professores procuram aproveitar os materiais didáticos produzidos e as orientações e capacitações oferecidas pelas instituições parceiras para desenvolverem seus próprios projetos. A coordenadora da Escola Particular B comenta sobre sua escola se utiliza dos materiais que chegam até ela, referindo-se à empresa Belgo:

"Eles vêm direcionados. Eles sugerem caminhos, porém a gente faz a nossa adaptação (...). Para eles o que conta na verdade é uma produção de textos que vai ser julgada, premiada, mas para a gente não é isso o importante. Para gente é o trabalho, o levantamento real que o aluno vai fazer". 
Assim, mesmo que a atividade contenha um caráter competitivo, a escola sabe minimizá-lo e utilizar as estruturas e facilidades oferecidas, adaptando os materiais didáticos à proposta pedagógica da escola.

Os trabalhos de EA das empresas nascem dentro dos seus núcleos de Responsabilidade Social das empresas e tendem a se alinhar ao apelo ambiental existente hoje na sociedade. Por mais que esses trabalhos possuam uma conscientização ecológica e, por isso, venham a surtir efeitos benéficos no meio ambiente, não podemos ignorar o fato de serem são projetos alinhados a uma filosofia de marketing verde. Estão mais preocupados com a sobrevivência da empresa no novo contexto socioambiental do que realmente a busca de novas maneiras de produção e, portanto, novas relações entre sociedade e natureza (CARVALHO, 1991; FOLADORI, 2001). É nesse sentido que questionamos: até que ponto os projetos de EA desenvolvidos pelas empresas estão comprometidos com a superação da crise ambiental e com transformação social?

\subsubsection{A elaboração dos projetos de Educação Ambiental}

Para os professores que disseram estar desenvolvendo algum projeto de EA ou que já desenvolveram, solicitamos que eles nos relatassem como acontece a elaboração dos projetos na escola. Como são elaborados os projetos? Quais são os objetivos dos projetos? Quais são as disciplinas e séries envolvidas nos projetos? E como ocorrem os trabalhos entre as disciplinas?

\subsection{Quem escreve os projetos de Educação Ambiental}

Os projetos idealizados pelas escolas ou são elaborados individualmente pelo professor que irá coordenar o projeto ou são elaborados coletivamente, onde cada professor escreve sua parte e só depois essas partes se juntam em um mesmo projeto. A professora de Ciências da Escola Particular B nos relata como são elaborados os projetos na sua escola:

“(...) cada matéria trabalhou da sua forma. Eu trabalhei assim, a professora de português de outra, a de geografia de outra, mas tudo voltado para o tema (...) Sentamos e discutimos. Verificamos se ninguém estava partindo para um mesmo lado, para que cada um fizesse um ponto diferente e que englobasse tudo que nós 
estávamos pensando. Daí cada professor entregou seu projetinho para coordenação".

Outros professores preferem escrever os projetos sozinhos. Esse é o caso da professora de Ciências da Escola Particular E, que prefere ouvir as opiniões de todos, elaborar o projeto e depois apresentá-lo:

\footnotetext{
"Eu escrevi sozinha. Mostrei para Cláudia (diretora) e pedi permissão para os outros professores se eu podia estar colocando todo mundo. (...) eu sou assim um pouco individualista em elaborar. Eu gosto de estar elaborando e depois coloco para cada um para saber o que acham e depois volto a escrever. (...) A gente faz uma reuniãozinha de 15-20 minutos, todo mundo palpita o que quiser e vou anotando, coloco no papel e depois distribuo de volta para eles para ver o que eles têm para colocar".
}

Se de um lado os projetos elaborados por vários professores são construídos como se a soma das partes resultasse no todo, do outro lado, os projetos elaborados individualmente são, na maioria das vezes, desenvolvidos apenas pelo o professor que o elaborou. O projeto de reciclagem da Escola Particular C e o da horta das Escolas Estaduais E e G foram organizados e desenvolvidos apenas pelos professores de Ciências.

Os projetos de instituições externas que chegam às escolas prontos não têm participação alguma dos professores na sua elaboração. Dentre os professores entrevistados, o professor de Geografia das Escolas Particulares B e E foi convidado para elaborar o projeto da empresa BelgoMineira e nos explica como acontece:

“(...) esse ano eu fui convidado para fazer aquele material da Belgo (...) A Belgo contrata uma empresa que fica responsável por isso, que fica responsável pela parte pedagógica do prêmio (...). O material já está pronto, mas só no ano que vem que ele vai para as escolas".

Ora, os professores e alunos deveriam optar pelos temas que acham mais convenientes à sua realidade, escolhendo a melhor maneira de desenvolver os projetos. Porém, acontece o contrário. Os projetos chegam às escolas em kits prontos, com orientação pré-definida e material de apoio já elaborado. 


\subsection{Objetivos e estratégias dos projetos de Educação Ambiental}

Durante a entrevista, pedimos aos professores que já desenvolveram projetos de EA ou que estavam em fase de planejamento que nos contassem quais eram os objetivos e as atividades desses projetos. Notamos que existe uma grande dificuldade em definir os objetivos e, consequentemente, as atividades que fazem parte dos projetos.

A professora de Ciências da Escola Estadual J nos conta como é o projeto que ela desenvolve com parceira do Semae e uma instituição do Canadá e que teve como objetivo discutir a problemática da água:

“(...) o Canadá queria uma escola de periferia que fosse carente para mandar o equipamento de laboratório. Por quê? Para ver a qualidade de água que eles consomem. A fonte de lazer deles é o riacho, é o córrego, é o riozinho que eles têm. Para ver que a água é um recurso que está acabando, que é um tema aí em moda e para eles sentirem na pele deles que não é porque o córrego está lá que não tem sujeira, não tem bactéria, que eles não enxergam ali. Aquela micozinha que eles têm na cara, que eles não ligam, aquela mancha de pele que é doença, que vem da água e como eles podem melhorar isto, eles podem fazer a parte deles não jogando lixo no chão, não jogando sofá no rio, não desmatando na beira do rio para construir barraco de favela..."

O primeiro fato que nos chama a atenção na fala acima é a maneira como a professora trata do assunto água com seus alunos. Ora, será mesmo que esses alunos e suas famílias não se importam com as manchas que aparecem nas suas peles? Será que ao resgatar a história de ocupação e surgimento do bairro a professora e alunos não poderão entender melhor o estado de degradação em que o riozinho se encontra hoje? A fala da professora parece não considerar as condições sociais de vida dos seus alunos e de como esse recurso natural é escasso em algumas comunidades, tornando-se um alvo de disputa política. A escola em que a professora leciona está situada num bairro muito pobre da cidade e se o projeto tem como objetivo levantar a problemática da água seria interessante ir além das análises feitas no laboratório e, juntamente com outras disciplinas, também incluir os aspectos históricos, políticos, culturais e sociais relacionados à problemática da água, nos níveis global e local.

A Escola Estadual H, no momento da pesquisa, desenvolvia um projeto sobre mata ciliar. O professor de Ciências nos relata como serão as atividades desse projeto: 
“(...) ele vai estar, no final do ano, plantando 240 árvores da mata ciliar (...) Dia 29 de abril nós fizemos a abertura com gincana e coleta de latinha de aluminio (...) Quinta-feira agora nós temos uma palestra sobre meio ambiente com 240 alunos lá no sindicato dos metalúrgicos. Depois, dia 8 e 10 de junho, lá na escola Industrial com 40 crianças (...) vão apreender a aproveitar tudo que tem em casa, reaproveitamento de alimentos, de folhas, cascas de bananas, de melancia...".

Diante de tantas atividades que o projeto propõe, perguntamos ao professor quais eram os objetivos do projeto:

"A finalidade do projeto nosso é fazer com que nossos alunos tomem consciência de não poluir o chão. Até estimulá-los a tirar o que está jogado no chão. (...) É porque você passando na beira do rio, na margem direita, ela é linda, mas você vê alguns pontos falhos. Aí, onde ficou falho, nós vamos plantar as árvores".

Certamente o professor mostra-se preocupado em desenvolver com seus alunos a consciência de manter o ambiente limpo ao mesmo tempo em que os sensibiliza para o problema do desmatamento da mata ciliar. Acreditamos, porém, que o projeto, ao tentar contemplar todas essas questões ao mesmo tempo, pode perder seus objetivos e dificultar que os alunos o acompanhem e façam as ligações entre as atividades propostas.

\subsection{A abrangência dos projetos de Educação Ambiental: as disciplinas e séries envolvidas}

Durante as entrevistas com os coordenadores e professores, pudemos confirmar que as disciplinas de Ciências e Geografia são as diretamente envolvidas com os projetos de EA desenvolvidos na escola. Essas são disciplinas ditas como "carro chefe" nos projetos de EA, principalmente a disciplina de Ciências, cabendo às demais disciplinas atuarem como colaboradoras. Assim, Matemática sempre é responsável pelos cálculos e estatísticas (quanto de lixo é produzido pela escola? Quantas latinhas foram coletadas?), Português fica responsável pela parte de redação e correção ortográfica e Artes assume as atividades de reaproveitamento de materiais descartados. Curiosamente, apenas uma escola citou a participação da disciplina de História em um dos seus projetos. Se é importante que a discussão ambiental gire em torno de uma contextualização histórica, política e cultural não é de se esperar que essa disciplina também seja considerada primordial na elaboração de projetos dessa natureza? 
Por mais que seja interessante a participação de várias disciplinas, será que essa não é uma participação fragmentada? As disciplinas juntas estão conseguindo ajudar os alunos a ter uma visão completa das questões que são tratadas nos projetos de EA? Nas escolas em que há o desenvolvimento de projetos temáticos o que vimos foi que a parte ambiental ficava sob a responsabilidade dos professores de Ciências, principalmente, e Geografia. Como acontece na Escola Particular F, onde o tema escolhido foi "São Paulo: terra das bandeiras e das pujanças". Embora a coordenadora diga que a EA esteja presente nas discussões de todas as matérias, a professora de Geografia, ao se referir ao mesmo projeto, responsabiliza a disciplina de Ciências como responsável por integrar a "parte" de EA:

"Em conjunto, liderado pela professora de ciências (...) Foi a parte dela, a minha foi sobre ferrovias... café e ferrovias (...). A professora de ciências trabalhou a parte ambiental...".

Mesmo na Escola Particular D que há mais de cinco anos trabalha com o tema água no ensino fundamental podemos observar uma forte participação de algumas disciplinas:

“(...) desde a primeira série é um enfoque na $5^{a}$ série, que é um conteúdo tanto de geografia quanto de ciências. (...) Começa em março, que é o dia mundial da água. Os alunos fazem pesquisa e nós tentamos integrar as atividades com matemática, Ciências e Geografia. Geografia fica com a parte mais de localização, dos rios, rede hidrográfica e poluição, Ciências com a questão da saúde, doenças transmitidas pela água e a matemática (...) sempre entra com a questão do consumo. (...) por que a água é uma coisa importante que tem que ser preservada? (...) $\mathrm{Na} 5^{a}$ série nós concluímos as atividades sobre a água com uma vista a Barra Bonita. A gente faz pesquisa na Internet, vê a localização, trabalha com mapa e vai ver em Barra Bonita o que é uma eclusa, hidrelétrica (...). Eles têm uma noção de como é o rio aqui e como é o rio lá (...) são projetos que a gente desenvolve há algum tempo já" (coordenadora e professora de Geografia da Escola Particular D).

Os projetos desenvolvidos em parceria nas escolas, na sua maior parte, acabam sendo inseridos através das disciplinas de Ciências e Geografia. Mesmo projetos que tenham a intenção de ser transversais, como o da Belgo que no ano da pesquisa desenvolveu um projeto com a temática "ética e meio ambiente", pudemos verificar que a porta de entrada na escola é ainda as disciplinas com conteúdos ambientais. De fato, essa forte relação da EA com os conteúdos programados de Ciências ou Geografia acaba facilitando para que os professores responsáveis por essas disciplinas 
tenham maiores facilidades em trabalhar com EA, uma vez que as atividades dos projetos estão voltadas predominantemente aos aspectos físicos e biológicos do ambiente.

Observamos também que existe uma concentração e preferência em direcionar os projetos para as primeiras séries do ensino fundamental, como as professoras de Ciências da Escola Estadual J nos relata sobre o projeto do Semae:

"Normalmente eles pegam só as $6^{a}$ séries. Então eu acho que fica um pouco restrito. Apesar de comentar o projeto em todas as séries. Então, eu estou trabalhando só com uma $6^{a}$ série e são 30 alunos que estão tendo esse treinamento".

"Foi bom porque dai este projeto é uma classe só e não são todos os alunos da classe. Pelo menos na minha época foram 20 alunos. Então, a gente saia para trabalhar com os alunos e restante ficava em sala de aula. Mas valeu”.

A fala da primeira professora nos mostra uma preocupação sobre a restrição que o projeto do SEMAE impõe. Já a segunda professora não tem uma postura tão crítica.

Assim, além de os projetos prestigiarem predominantemente as disciplinas de Ciências e Geografia, são também direcionados para as primeiras séries dos ciclos iniciais do ensino fundamental.

\subsubsection{4 $O$ trabalho entre as disciplinas}

Ao serem questionados sobre os trabalhos de EA entre as disciplinas, muitos professores entrevistados demonstraram uma dificuldade de visualizar a participação de outras disciplinas que não sejam Ciências e Geografia nos projetos de EA:

"Interdisciplinar é muito complicado. Até porque é assim, existem várias visões a respeito do que é Educação Ambiental, de como trabalhar e tudo mais. E nem sempre as disciplinas concordam com o trabalho especifico de alguma visão. Por exemplo, Matemática, eu não conseguiria entender como eu trabalharia Matemática na Educação Ambiental como eu trabalho com Geografia (...). Assim, os projetos que a escola faz e com esses eventos, como a mostra cientifica, isso é bem legal. Até tem a interação, mas das áreas mais afins. Então, eu estou desenvolvendo algo com a professora de História, com a professora de Ciências e eles também. Essa é a relação mais tranqüila que a gente tem. (...) No caso da Geografia eu acho mais tranqüilo porque a Educação 
Ambiental está dentro dos conteúdos da Geografia, mas no caso das outras disciplinas eu imagino que fique mais complicado" (professor de Geografia das Escolas Particulares B e E).

"Não tem nem como ainda. Matemática, Português... eu acho que redação trabalha bastante por causa de temas. Eu acho que é por falta de como fazer" (professora de Ciências da Escola Particular C).

Há também uma preocupação de não invadir a área do outro professor. $O$ professor de Matemática da Escola Estadual I explica como foi questionado por seus colegas ao construir uma horta na sua escola:

“(...) professores que não entendem às vezes porque eu estou trabalhando ali e estou entrando nas áreas deles. Isto ai se chama interdisciplinaridade. E assim como ele pode entrar na minha área (...) outro dia me perguntaram - entende de horta? (...) Eu posso trabalhar meio ambiente (...) está tudo relacionado (...). Impossivel você separar a Matemática do meio ambiente".

Muitos trabalhos entre professores acabam sendo realizados porque existe uma afinidade dos conteúdos entre as disciplinas que lecionam:

“(...) comigo, o professor de História e o de Geografia a apostila - porque a gente tem que seguir a apostila - segue sempre a mesma cronologia. Então, se ele está falando de Grécia Antiga, eu também estou falando de Grécia Antiga. Se ele está estudando o solo da Europa eu estou tratando de Europa. (...) é mais fácil no dia-a-dia a gente trocar. Então, ele dá uma parte da aula eu passo um filme para completar a aula dele" (professora de Artes da escola particular C).

Ou porque existe também um entrosamento entre os professores:

“(...) o que eu vejo é que é mais fácil trabalhar Geografia com Ciências e alguns professores têm mais afinidades. Então, $5^{a}$ séries os professores já estão há muito tempo aqui e são os mesmos professores. Então, é muito mais fácil trabalhar com Geografia, com as Ciências e Matemática, por exemplo. E isso tem a tempo. Nas $\sigma^{a}$ séries são os mesmos professores, na $7^{a}$ mudam os professores, só que nós não temos dificuldades"'(coordenadora e professora de Geografia da escola particular D).

As falas dos entrevistados sobre as questões referentes às práticas de EA nos permitiram identificar as maneiras como a temática ambiental vem sendo incorporada no ensino formal: através dos conteúdos programados de suas disciplinas, no desenvolvimento de projetos temáticos e também 
em outras atividades que são desenvolvidas de maneiras mais pontuais pelos professores ao abordar a EA. De fato, a segunda etapa da pesquisa diagnóstica sobre a implementação da EA nas escolas, realizada pelo MEC e Inep com 418 escolas nas cinco regiões do país, verificou também a diversidade com que a EA é trabalhada nas escolas. Constatou que são três as modalidades de trabalhos com EA: ações através de projetos $(66 \%)$, através da inserção no projeto políticopedagógico (38\%) e por meio da transversalidade nas disciplinas (34\%); e concluiu que "mesmo diante das dificuldades estruturais da escola quanto à flexibilidade da organização curricular disciplinar, está se buscando caminhos integradores que insiram a Educação Ambiental em diferentes disciplinas ou atividades" (BRASIL, 2007b, p. 22).

Existe um interesse muito grande das escolas em se trabalhar EA sob a forma de projetos. Mas, perguntamos: em que medida a EA é trabalhada de maneira interdisciplinar pela escola? Nas palavras de Tristão (2002):

O que, de fato, acontece nas práticas pedagógicas de Educação Ambiental, denominadas interdisciplinares, não passa de multidisciplinares. Como as disciplinas de geografia e biologia têm uma afinidade de conteúdos em relação à dimensão ambiental, a inserção da educação ambiental ocorre por meio de um exercício multidisciplinar, às vezes até uma cooperação entre os conteúdos dessas disciplinas (TRISTÃO, 2002 apud GUIMARÃES, 2003, p. 125).

Realmente, o que ocorre com mais freqüência são trabalhos entre as disciplinas que têm certas afinidades, como é o caso da Ciência e da Geografia, trabalhos entre professores da mesma disciplina ou, simplesmente, os projetos são desenvolvidos por uma única disciplina. A dificuldade em trabalhar com projetos nas condições que atualmente as escolas impõem é ilustrada no caderno de apresentação do Programa Parâmetro em Ação - Meio Ambiente na Escola, do MEC:

Os projetos de Educação Ambiental em geral não estão articulados ao projeto da escola. Grande parte das escolas sequer tem um projeto educativo, e assim não pode oferecer aos professores condições espaciais, temporais e materiais de trabalhar coletivamente e de forma integrada. Esse quadro dificulta um trabalho com a transversalidade e a interdisciplinaridade propostas para a prática da Educação Ambiental (BRASIL, 2001, p. 106).

Certamente, desenvolver projetos dessa maneira pouco, ou mesmo nada, contribuirá para a inserção da EA na escola. Espera-se que os projetos estejam integrados à posposta políticopedagógica da escola e trabalhados de maneira participativa por todos os atores escolares, e não 
sejam de responsabilidade de um ou dois professores, de tal forma que desenvolvam os projetos de maneira isolada e independentemente das outras atividades da escola. Guimarães (2003) também concorda que o trabalho com projetos pedagógicos é uma maneira viável para incorporar a EA na escola, mas também critica a forma como vêm sendo desenvolvidos os trabalhos com projetos, pois é, na verdade, uma maneira disfarçada de transmitir os conteúdos programados, pouco se diferenciando da pedagogia tradicional. É nesse sentido que o autor, entre outros educadores ambientais, defende uma proposta de projetos pedagógicos concebidos dentro da concepção freireana, em que há uma inserção crítica dos educandos e educadores e uma investigação através da problematização dos temas geradores:

O projeto, como uma prática participativa e problematizadora, que se estabelece no cotidiano escolar, tem como ponto de partida a realidade local. É nessa realidade que se buscará, pela investigação, o "universo temático"; mas que seja uma "temática significativa" para os que participam do processo, não o tema escolhido pelo professor, diretor ou projetos fechados de secretarias, ong's e empresas (GUIMARÃES, 2003, p. 125)

Layrargues (1999 apud LIMA, 2004), ao analisar as estratégias metodológicas de EA que trabalham por meio de resoluções de problemas locais, faz uma diferenciação entre abordagens com "tema-gerador" e abordagem, que o autor denomina, de "atividade-fim". Para o autor, a primeira abordagem está comprometida com a transformação da realidade local, enquanto a segunda tem um caráter de buscar soluções pontuais para o problema ambiental. Lima (2004), baseado em Layrargues (1999), complementa:

Enquanto a abordagem da atividade-fim prioriza a compreensão técnica do problema, o foco sobre o efeito e uma ação de tipo corretiva e produz um resultado reducionista, reformista e despolitizador já que dilui a responsabilidade social sobre o problema, a abordagem do tema-gerador enfatiza uma visão multidimensional do problema que integre a crítica, o foco sobre a causa, a ação preventiva e a dialogicidade entre educador e educando. Neste caso, o resultado produzido tende a estimular uma compreensão complexa, politizadora e transformadora dos problemas socioambientais (LIMA, 2004, p. 100).

Concordamos que trabalhar com projetos é uma maneira de facilitar a entrada da EA no ambiente escolar, porém, conforme observamos nos depoimentos dos professores, os projetos são trabalhados de maneira improvisada e desarticulada do contexto curricular da escola. Para que os projetos se transformem, de fato, na porta de entrada da EA nas escolas, é preciso que eles sejam 
desenvolvidos em comunhão com o projeto político-pedagógico da escola; que seja trabalhado por uma equipe formada por professores de diferentes disciplinas; que trate a questão ambiental na sua totalidade e complexidade, de maneira interdisciplinar; que incorpore outros saberes, além do saber já tradicionalmente sistematizado pelo ensino escolar; que estimule uma postura participativa e criativa de educadores e educandos. Enfim, os projetos devem ser desenvolvidos de maneira que possam construir outras possibilidades de ensino e aprendizagem e que se oponham às práticas pedagógicas vigentes e dominantes nas escolas e, portanto, contribuam efetivamente para a inserção da EA no currículo escolar.

\subsubsection{Os recursos utilizados com os trabalhos de Educação Ambiental}

Durante as entrevistas com os professores, os coordenadores e a diretora das escolas selecionadas foram levantados os materiais didáticos utilizados nas atividades de EA. Diante das respostas dos entrevistados, pudemos organizá-las da seguinte maneira: recursos materiais (vídeos, livros, cartazes, etc.), recursos metodológicos (excursões, dinâmicas, debates, teatro, etc.) e recursos provenientes do ambiente natural (água, solo, mudas de árvores).

\subsubsection{Recursos materiais}

Os textos (13), livros e apostilas didáticos (12) e vídeos (12) foram os materiais mais citados pelos entrevistados como recurso material utilizado nos trabalhos com EA. A tabela 5 reúne todos os recursos materiais utilizados pelos professores, com as freqüências de cada recurso e separado por disciplina.

Os textos citados pelos professores são usados para completar o assunto que está sendo tratado no momento. Suas origens são variadas, sendo que os jornais e as revistas foram mencionados oito vezes pelos entrevistados, a internet e livros didáticos citados três vezes cada. Quatro entrevistados não especificaram a origem dos textos que utilizam. 
Tabela 5 - Recursos materiais utilizadas pelos professores e o número de vezes que foram citadas, em ordem decrescente Legenda: C (Ciências); G (Geografia); A (Artes); M (Matemática) e P (Português)

\begin{tabular}{|c|c|c|c|c|c|c|}
\hline Recursos materiais & $\mathbf{C}$ & $\mathbf{G}$ & $\mathbf{A}$ & $\mathbf{M}$ & $\mathbf{P}$ & Total \\
\hline Textos & 10 & 2 & - & - & 1 & 13 \\
\hline $\begin{array}{l}\text { Livro didático/ } \\
\text { Apostila }\end{array}$ & 8 & 3 & 1 & - & - & 12 \\
\hline Vídeo & 8 & 4 & - & - & - & 12 \\
\hline $\begin{array}{c}\text { Cartazes /painéis / } \\
\text { Murais }\end{array}$ & 3 & 2 & - & - & - & 5 \\
\hline Cartilha/folhetos & 5 & - & - & - & - & 5 \\
\hline Dados estatísticos & 1 & - & - & 3 & - & 4 \\
\hline Fotos & 2 & 2 & - & - & - & 4 \\
\hline Lousa/giz/apagador & 4 & - & - & - & - & 4 \\
\hline Materiais reciclados & 1 & - & 2 & 1 & - & 4 \\
\hline Mapa/globo terrestre & - & 4 & - & - & - & 4 \\
\hline Acervo da biblioteca & 1 & 1 & - & - & - & 2 \\
\hline Computador & - & - & - & 1 & - & 1 \\
\hline $\begin{array}{l}\text { Ferramentas para } \\
\text { Jardinagem }\end{array}$ & 1 & - & - & - & - & 1 \\
\hline Laboratório & 1 & - & - & - & - & 1 \\
\hline Liquidificador & 1 & - & - & - & - & 1 \\
\hline Lixo da sala de aula & - & - & - & - & 1 & 1 \\
\hline Histórias em quadrinhos & 1 & - & - & - & - & 1 \\
\hline Música & 1 & - & - & - & - & 1 \\
\hline Papel cartão & - & 1 & - & - & - & 1 \\
\hline
\end{tabular}

Os livros e apostilas didáticos firmam-se ainda como uma forte referência para as práticas de ensino em geral, sendo válidos também como recurso nas atividades relacionadas à EA. A fala da professora de Ciências da Escola Particular F nos releva que, ainda que ela procure outras fontes de 
materiais para complementar sua prática, o livro didático tem uma influência muito grande nas suas aulas:

“(...) eu procuro incrementar as aulas trazendo novidades, mas eu procuro seguir o livro didático que tem seguido pela escola e eu procuro trazer coisas novas para eles".

Os vídeos obtiveram doze citações entre os entrevistados. Os títulos dos vídeos foram: Água na Boca, com quatro citações; "Ilha das Flores", com duas citações; e "Dom Quixote Reciclado" (Tetra Pak), três vezes citado. Muitos professores não recordavam os títulos dos vídeos que utilizam, citando apenas sua temática, como Amazônia, água, aquecimento global, meio ambiente e horta. Esses vídeos são originados do Semae (4), Tetra Pak (3), EPTV (1), Esalq (1) DE (1). Em sete citações de uso de vídeos, não foi possível identificar a origem dos mesmos.

Os outros recursos materiais citados pelos professores foram os cartazes e materiais reciclados, com seis citações cada; fotos, dados estatísticos e giz/lousa/apagador, com quatro citações.

As cartilhas, livrinhos, folders, folhetos e outros materiais produzidos e distribuídos pelas empresas que possuem programas de EA tiveram doze citações entre os entrevistados. As empresas responsáveis foram Belgo-Mineira, CPFL, DPaschoal e Faber Castell.

\subsubsection{Recursos metodológicos}

Dentre os recursos metodológicos mais citados pelos professores temos a pesquisa, que soma dez citações. Porém, se somarmos as respostas dos professores com as dos coordenadores e diretora entrevistados, temos que as excursões, passeios e/ou visitas representam um total de dezenove citações. A tabela 6 reúne as respostas dos professores das diferentes disciplinas em relação aos recursos metodológicos e a freqüência com que foram citados.

As origens das pesquisas (10) são diversas, podendo ser na Internet (6), pesquisa de campo (4), pesquisa feitas em jornais (1) e em revistas (1). Um professor não especificou a natureza da pesquisa a que estava se referindo. As excursões (7) foram realizadas através das parceiras com o Semae (4) e a empresa Votorantim (4), e as demais citações são de responsabilidade das escolas. 
Tabela 6 - Recursos Metodológicos utilizados pelos professores e o número de vezes que foram citadas, em ordem decrescente

Legenda: C (Ciências); G (Geografia); A (Artes); M (Matemática) e P (Português)

\begin{tabular}{|c|c|c|c|c|c|c|}
\hline Recurso metodológico & C & $\mathbf{G}$ & $\mathbf{A}$ & $\mathbf{M}$ & $\mathbf{P}$ & Total \\
\hline Pesquisa & 4 & 5 & - & 1 & - & 10 \\
\hline Excursões/visitas & 3 & 4 & - & - & - & 7 \\
\hline Palestras & 5 & 1 & - & - & - & 6 \\
\hline Conversa & 3 & 2 & - & - & - & 5 \\
\hline Maquetes & 1 & 2 & 1 & - & - & 4 \\
\hline Redação/estórias & 1 & 2 & - & 1 & - & 4 \\
\hline Debate/discussão & 2 & - & - & - & 1 & 3 \\
\hline Fotografia & 1 & 2 & - & - & - & 3 \\
\hline Dinâmica & 1 & 1 & - & - & - & 2 \\
\hline Paródia & - & 2 & - & - & - & 2 \\
\hline Dança & - & 1 & - & - & - & 1 \\
\hline Desenho & - & 1 & - & - & - & 1 \\
\hline Filmagem & - & 1 & - & - & - & 1 \\
\hline $\begin{array}{l}\text { Histórias em } \\
\text { quadrinhos }\end{array}$ & 1 & - & - & - & - & 1 \\
\hline Gincana & 1 & - & - & - & - & 1 \\
\hline Mapa conceitual & - & 1 & - & - & - & 1 \\
\hline Quebra-cabeça & 1 & - & - & - & - & 1 \\
\hline Teatro & - & - & 1 & - & - & 1 \\
\hline
\end{tabular}

Outros recursos metodológicos citados foram palestras (6), conversas (5), maquetes (4), redação/estórias (4), o uso de fotografias (3) e debates/discussões (3). Dinâmicas, gincanas, teatro, exposições, paródia de músicas, dança, produções escritas e desenhos são outros recursos utilizados pelos entrevistados em seus trabalhos com EA. 
Alguns recursos metodológicos utilizados pelos professores possibilitam uma participação mais ativa dos alunos, como a utilização de pesquisas, debates/discussões e fotografia:

"A gente faz na forma de debate, vão colocando na lousa quem é a favor e quem é contra...Já chegamos a trazer reportagem para comentar, coisas que eles viram, a montar murais dentro da sala de aula" (professora de Ciências da Escola Estadual G).

“(...) vamos pensar no nosso bairro aquilo que você acha que não está legal ou alguma coisa neste sentido. Fizemos um trabalho com comparação: o que é legal, o que é bom. O que é o ambiente bom e o que não é para eles. Então eles saíam e, por exemplo, faziam uma fotografia. Às vezes eles pegavam um lixo que estava na rua ou... a foto de uma coleta seletiva."(professora de Ciências da Escola Estadual F).

Outros recursos, como palestras, indicam que algumas atividades estão mais centradas no professor ou no palestrante, sendo estes os que possuem o conhecimento que deve ser transmitido aos alunos (CARVALHO, 1989).

\subsubsection{Recursos do ambiente}

A água foi o recurso do ambiente mais citado pelos entrevistados, com cinco citações. Em seguida vem o uso de paisagens e/ou paisagismo, com quatro citações, a utilização de mudas e folhas das árvores, com três citações e, finalmente, o uso do solo, com duas citações entre os entrevistados.

Diante das respostas dos professores aos recursos por eles utilizados nas atividades de EA podemos tirar algumas conclusões. Primeiramente o que fica evidente nas falas dos professores é a falta de materiais didáticos próprios para desenvolver trabalhos com EA:

"Recursos apenas lousa e livro didático... Eu sei que é pouco, mas é o único que tem. Muito pouco..." (professor de Ciências da Escola Estadual G).

"Dentro da escola? É meio complicado (...) Nós não tínhamos recursos algum, qualquer material que eu quisesse trabalhar eu levava, eu comprava, eu pedia para os alunos. Dentro da escola é carteira, cadeira, lousa e giz. É o recurso que a gente tem..." (professora de Ciências da Escola Estadual E). 
Tabela 7 - Recursos do ambiente utilizados pelos professores e o número de vezes que foram citadas, em ordem decrescente

Legenda: C (Ciências); G (Geografia); A (Artes); M (Matemática) e P (Português)

\begin{tabular}{c|c|c|c|c|c|c}
\hline Recurso do ambiente & C & G & A & M & P & Total \\
\hline Água & 2 & 3 & - & - & - & 5 \\
$\begin{array}{c}\text { Paisagens/paisagismo } \\
\text { Mudas e folhas de } \\
\text { árvores }\end{array}$ & 1 & 1 & 1 & - & 1 & 4 \\
Solo & 2 & - & - & - & - & 3 \\
\hline
\end{tabular}

Assim, as apostilas ou livros didáticos são os recursos mais utilizados pelos professores para auxiliar seus trabalhos de EA. A influência dos livros didáticos e seu uso maciço nas atividades de EA foram apontados e criticados por diversos autores (CARVALHO, 2002a, 1989; DIAS, 1999; GRÜN, 1994, 1996; MARTINS, GUIMARÃES, 2002; MEYER, 1994; entre outros). Segundo esses autores, a maioria dos livros didáticos traz informações defasadas, confundem EA com o conteúdo ecologia, dão enfoque utilitarista da natureza e abordam os problemas ambientais de maneira fragmentada, enfatizando mais seus sintomas do que propriamente o porquê das suas causas e as possíveis soluções. Por isso, para Grün (1996), os livros didáticos "frequentemente trazem explícita ou implicitamente padrões culturais que reforçam o mito do antropocentrismo" (p. 45).

As publicações direcionadas à EA são não só recentes como também têm caráter predominantemente informativo. Ao pesquisar os materiais impressos sobre EA, Trajber e Manzochi (1996 apud CARVALHO, I., 2002a) observaram uma porcentagem muito maior de materiais do tipo informativo, como folder, folhetos e cartilhas, do que dos materiais do tipo reflexivo, como os livros didáticos e paradidáticos. Essa dificuldade para encontrar recursos didáticos é ainda mais evidente nas disciplinas que não são tradicionalmente relacionadas com EA. Ao comparar as repostas dos professores de Artes, Matemática e Português com as respostas dos professores de Ciências e Geografia, observamos que esses primeiros mencionam muito menos recursos do que as disciplinas cujos os conteúdos são considerados "ambientais". 
É claro que somos sensíveis às dificuldades de se conseguir recursos didáticos mais apropriados. Porém, ainda é muito viva a idéia de que EA só possa ser feita fora da sala de aula, de preferência com excursões para parques ou lugares distantes da escola ou no desenvolvimento de projetos que demandem recursos e manutenções. O ambiente local, por exemplo, já há muito tempo é conhecido na literatura sobre práticas educativas relacionadas ao meio ambiente como um recurso que pode ser utilizado para o desenvolvimento dos trabalhos de EA (CARVALHO, 1989). Porém, foram poucos os professores que se utilizaram desse recurso e, em especial, o próprio espaço físico da escola. As elevadas menções dos entrevistados em relação às excursões comprovam que essa é ainda uma prática preferencialmente adotada. Mas, novamente, diante de um contexto escolar em que os recursos são escassos, essa prática envolve grandes dificuldades. Soma-se a isso uma situação controversa. Nas escolas em que as possibilidades de atividades extraclasse são raras, principalmente nas carentes, essas atividades são usadas como punição pela direção escolar e corpo docente aos alunos que apresentem mau comportamento. Em uma das visitas feitas (Escola Estadual H), pudemos acompanhar, durante o HTPC, como era feita a seleção dos alunos que iam e os que não iam a um passeio que a escola estava programando. Os professores, juntamente com a coordenadora e diretora da escola, cortavam da lista aqueles alunos que consideravam ter um mau comportamento.

Não negamos que a possibilidade de construir uma horta escolar ou conhecer o tratamento de água e esgoto da cidade, por exemplo, possam enriquecer os trabalhos direcionados para a EA. O problema é que essas são atividades que, além de exigirem trabalhos extras dos professores, também necessitam de uma estrutura que a maioria das escolas não possui. Assim, ao invés de serem atividades que contribuam para o desenvolvimento da EA, as dificultam. Segura (2001) também encontrou essa dificuldade em relação aos recursos materiais e financeiros para desenvolver atividades extraclasse na sua pesquisa. Para a autora, o que acontece é que em geral os professores associam a EA a "fazer algo" prático, como a construção de uma horta ou a coleta seletiva. Ela também aposta em atividades que usam o contexto local como uma alternativa para trabalhos de EA. 


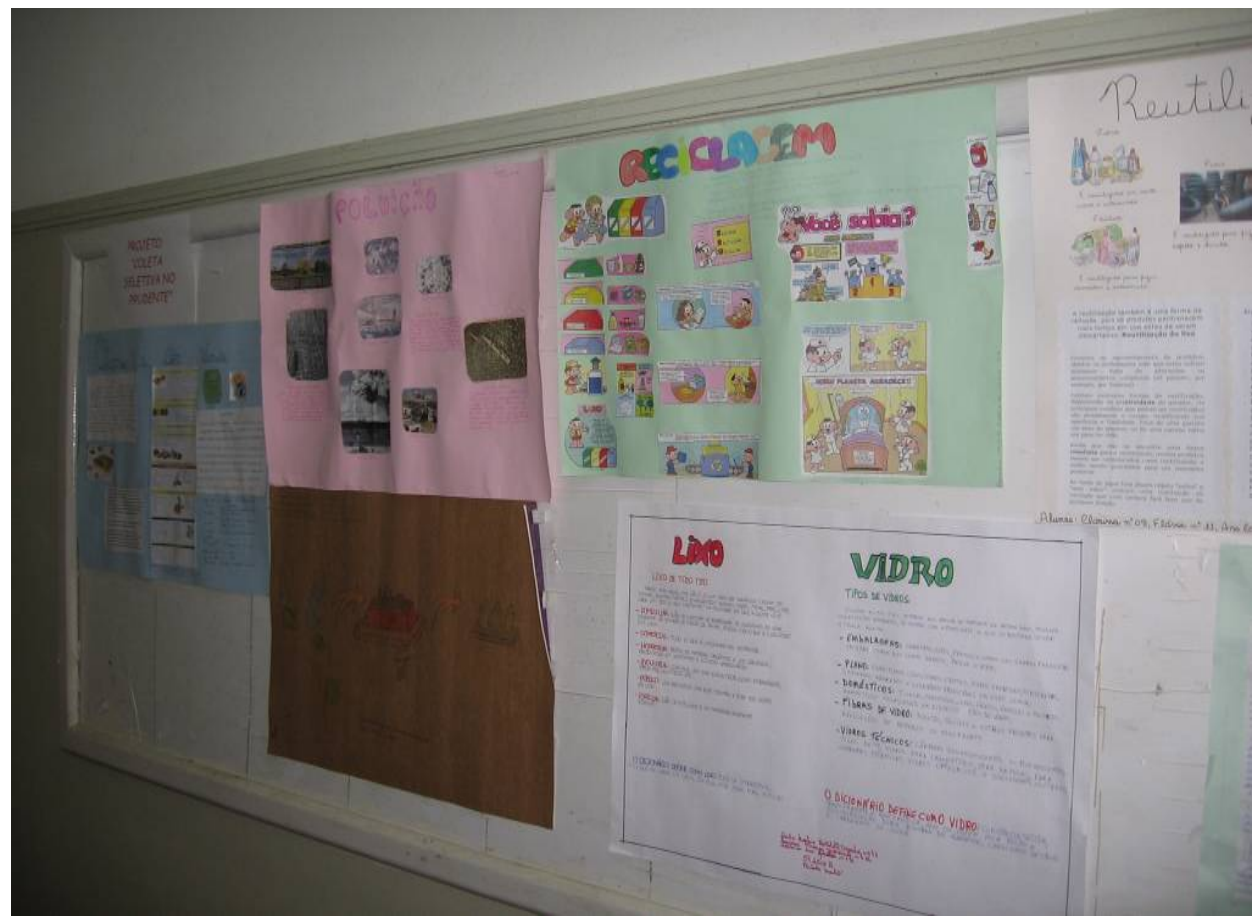

Figura 16 - Cartazes sobre reciclagem expostos no corredor de uma escola estadual

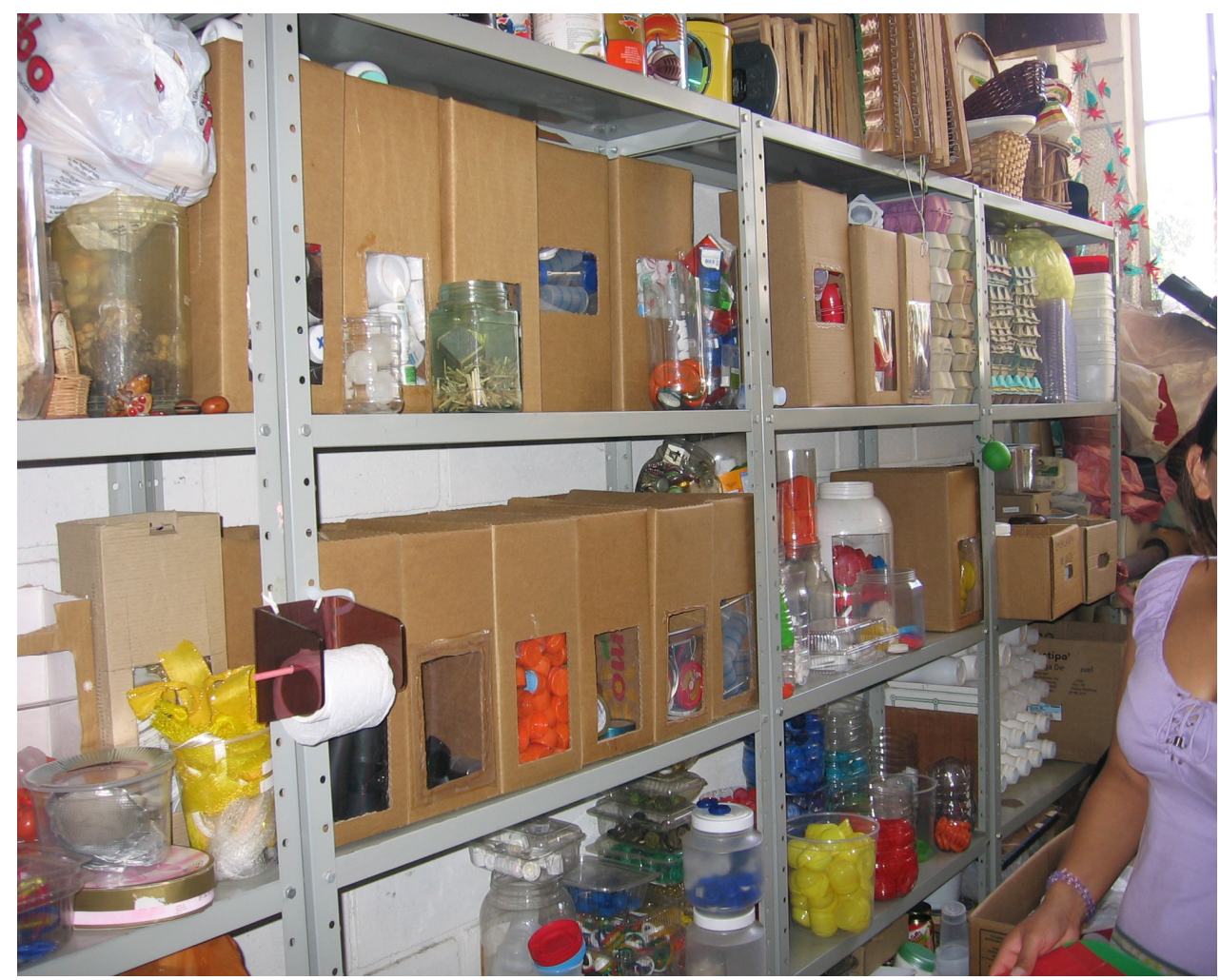

Figura 17 - Sucateca de uma escola particular 


\subsubsection{As carências e dificuldades nos trabalhos com Educação Ambiental na escola}

Ao serem questionados se estavam satisfeitos com os trabalhos de EA que desenvolvem, alguns professores disseram que sim (12), que se sentiam satisfeitos. Outros professores disseram não estar satisfeitos (5) ou que não se sentiam totalmente satisfeitos com os trabalhos de EA por eles realizados (5).

Entre os que estão satisfeitos temos respostas como as professoras de Ciências e Português da Escola Estadual K, respectivamente:

"Eu já passei por aquela fase que você tem que fazer tudo, tudo tem que dar certo se não você não fica feliz. Eu já estou naquela fase que se eu consegui com alguns alunos, se alguns mudarem (...) algumas atitudes, eu já estou satisfeita e isso eu já tenho conseguido. Por aí eles vão ser os multiplicadores, eles mudaram, eles conseguiram, aí os outros vão aprendendo (...) aí a gente vai conseguir um resultado maior (...) Demora, mas vamos conseguir".

"Eu me sinto muito satisfeita com que eu proponho e realizo. Mesmo que seja difícil de conseguir a concretização eu me sinto feliz (...) Eu acho que sou uma professora idealista. E eu me sinto bem em idealizar algo que vai contribuir de alguma forma para a formação dessas pessoas que estão comigo".

Entre os professores não satisfeitos ou não totalmente satisfeitos, temos:

"Eu acho que a gente poderia sair mais fora da classe" (professora de Ciências da Escola Particular E).

"Não, eu acho que poderia ser muito melhor (...) eu acho que deveria ser trabalhado bem mais" (professora Geografia da Escola Estadual J).

"Eu acho que ainda está engatinhando. Eu acho que deveria ser uma coisa de levar mais a sério" (professora de Ciências da Escola Estadual J).

A fala da primeira professora claramente relaciona a EA ao fazer alguma atividade prática, de preferência fora da sala de aula. As outras duas professoras mostram-se desapontadas com o que tem sido feito de EA atualmente nas escolas. 


\subsubsection{As dificuldades encontradas pelos professores quando trabalham com Educação Ambiental}

Durante as entrevistas foi solicitado aos professores que relatassem as dificuldades que encontravam ao desenvolver trabalhos com EA, tanto na sala de aula quanto em relação aos projetos. A Figura 18 reúne as dificuldades citadas pelos entrevistados.

\begin{tabular}{|c|c|}
\hline $\begin{array}{c}\text { Em relação aos conteúdos } \\
\text { programados } \\
\text { e ao material didático }\end{array}$ & $\begin{array}{l}\text { - "Vencer" os conteúdos } \\
\text { - Seguir o livro didático / apostila } \\
\text { - } \quad \text { Falta de material didático apropriado }\end{array}$ \\
\hline $\begin{array}{c}\text { Em relação à } \\
\text { estrutura escolar }\end{array}$ & $\begin{array}{l}\text { - } \text { Faltam recursos para as atividades } \\
\text { - } \text { Burocracia para saídas dos alunos } \\
\text { - } \text { Rotatividade dos professores } \\
\text { - } \text { Horários de reuniões insuficientes } \\
\text { - } \text { Tempo escasso para planejamento } \\
\text { - } \text { Excesso de projetos } \\
\text { - } \text { Inexistência de avaliações }\end{array}$ \\
\hline $\begin{array}{c}\text { Em relação à formação } \\
\text { dos professores }\end{array}$ & $\begin{array}{l}\text { - } \text { Falta de conhecimento/formação na área } \\
\text { - } \text { Orientação insuficiente às atividades } \\
\text { - } \\
\text { - } \\
\text { - Não há troca de experiências } \\
\text { - Medo de arriscar }\end{array}$ \\
\hline $\begin{array}{c}\text { Em relação à motivação e } \\
\text { Comprometimento }\end{array}$ & $\begin{array}{ll}\text { - } & \text { Referente aos alunos } \\
\text { - } & \text { Referente aos professores } \\
\text { - } & \text { Referente à comunidade escolar }\end{array}$ \\
\hline
\end{tabular}

Figura 18 - Dificuldades citadas pelos professores entrevistados ao se trabalhar com EA 


\subsection{Em relação à estrutura escolar}

Muitas das dificuldades levantadas pelos professores são em relação às estruturas das instituições que eles enfrentam no seu dia a dia. A maioria dessas dificuldades não está relacionada exclusivamente aos trabalhos de EA, mas acabam afetando o seu desenvolvimento.

O excesso de alunos por classe acaba inibindo o desenvolvimento de atividades fora da sala de aula, como excursões e passeios, ou mesmo dentro da própria escola, como aulas no laboratório de Ciências ou em pesquisas na sala de informática:

“(...) eu não posso sair com quarenta alunos e trabalhar com estes quarenta alunos sozinha (...) você acaba esbarrando nestas coisas burocráticas para você sair (...) não só educação ambiental, mas tudo. Todo este processo escolar, que é pesado, precisaria menos alunos em sala de aula" (professora de Ciências da Escola Estadual G).

As horas extras e a carga horária pesada dos professores também dificultam sua dedicação aos projetos de EA. O professor de Matemática da Escola Estadual I relata o tempo que ele dispõe para o projeto de horta da sua escola:

“(...) além das minhas 32 horas-semanais aqui, às vezes eu disponho dos meus fins de semana. Então, eu estou ingressando aqui como voluntário".

A falta de recursos e de apoio nos projetos é outra dificuldade para desenvolver trabalhos com EA. A professora de Ciências da Escola Estadual G relata como foi prejudicada a continuação do projeto horta na sua escola:

“(...) O problema nosso é que acabou o ano e não tem uma pessoa para estar ali vendo, entendeu? Então, acaba se perdendo. E quando você volta no outro ano foi tudo por água abaixo".

Isso faz com que muitos professores acreditem que projetos com parcerias externas ajudem bastante, sendo que para alguns professores somente com parcerias os projetos são viáveis dentro da escola, pois as instituições parceiras oferecem material didático, capacitações para os docentes, ônibus para as excursões, etc. 
Outra dificuldade encontrada nas escolas é a rotatividade dos professores, principalmente nas escolas estaduais:

"A alta rotatividade de professores e muitos professores que dão uma ou duas aulas e acabam não tendo envolvimento. Porque é um trabalho que você só consegue alguma coisa a longo prazo. Então é um trabalho que você vai indo devagarzinho e tem que ter uma constância" (professora de Ciências da Escola Estadual F).

Vale lembrar que, dentre os entrevistados, dez professores estão há um ano ou menos na escola em que foram entrevistados. A fala da professora de Ciências da Escola Estadual E elucida bem o quanto a saída de um professor pode prejudicar a continuidade dos trabalhos de EA que já estavam sendo desenvolvidos e o quanto é difícil para o professor recomeçar seus projetos em uma escola nova:

“(...) eu ainda não comecei a trabalhar porque eu estava numa outra escola e eu estou chegando aqui agora porque fui removida. Então eu fiz o planejamento e estou conversando com o outro professor de Ciências para gente estar trabalhando um projeto aqui na escola. Sempre eu trabalho no conteúdo a temática ambiental (...) mas eu ainda não comecei a trabalhar muito especificamente porque ainda eu estou conhecendo um pouco a escola, os alunos...”.

Realmente, o afastamento de um professor pode comprometer todo o andamento do projeto:

“(...) como a professora de Geografia está afastada eu parei (...) sozinho eu achei que não ia dar conta do recado” (professor de Ciências da Escola Estadual G).

"Olha, a professora saiu de licença agora. Então, ela ficou o ano todo e ela tirou licença prêmio por três meses. Eu sei que ela trabalhou a parte de reciclagem porque tem aqui o material da Tetra Pak (...) Mas eu não sei especificar para você o quê (...) Mas agora para o ensino fundamental a gente não faz nem um mês que está com eles, então a gente ainda está se adaptando..." (professora de Ciências da Escola Estadual D).

Outra dificuldade é ter horários de planejamento para os trabalhos de EA, principalmente os trabalhos entre as disciplinas. Os horários de reuniões entre os professores muitas vezes não são suficientes para tratar de todas as questões importantes da escola. Os projetos, atividades e trabalhos com EA ficam em segundo plano, sendo planejados no pouco tempo que resta: 
“(...) existe sempre outra coisa que é prioridade e que vai sendo colocada na reunião. Sempre tem alguma coisa, sempre nota de alunos, (...) tem que preparar a reunião de pais, e tem que preparar as fichas, não tem funcionário para fazer a fichinha individual de cada aluno com as notas e a gente que tem que fazer. Ai, usa-se esse horário. As vezes tem avisos, outras vezes vem alguém da OPEOSP para passar alguma informação. Então, o projeto sempre fica em segundo plano" (professora de Português da Escola Estadual K).

Dessa forma, os projetos ou trabalhos em conjunto acabam sendo elaborados no tempo que é possível, em intervalos e conversas rápidas na sala dos professores ou mesmo nos corredores.

"É dificil porque normalmente nos HTPCs, não aqui só, mas em todos os espaços por onde passei, tem muitos recados para passar, tem muitos problemas para resolver. Então, muitas vezes, não acaba sobrando muito tempo para estar discutindo isto (...). Se tiver algum projeto com algum colega acaba comentando nos intervalos, nas salas de aula..." (professora de Ciências da Escola Estadual B).

"É meio complicado. (...). A gente se esbarra para conversar: você está fazendo tal coisa? Dá para você trabalhar isso porque eu estou trabalhando aquilo, sabe? Tudo é muito rápido. Porque os professores acumulam sempre dois cargos. (...) então, a gente consegue conversar nesses HTPCs que são esporádicos e nos planejamentos.(...) Duas vezes ao ano, uma no começo e outra no meio do ano. (...) É a falta de tempo dos professores. A gente sente que peca nisso" (professora de Ciências da Escola Particular B e coordenadora da Escola Estadual J).

Os projetos são construídos na forma de um mosaico, de modo que cada professor escreve sua parte para depois juntar com o restante, esperando sempre que a soma das partes possa resultar num todo. Porém, muitos professores parecem desconhecer o trabalho do outro, prevalecendo a falta de diálogo:

"Olha, outras disciplinas eu não sei, precisaria estar perguntando para os outros professores, eu posso só falar da minha" (professora de Ciências da Escola Estadual B).

"Essa professora que está trabalhando agora eu não sei se ela está dando continuidade por projetos. Que eram projetos de hortas, tinha um outro projeto de educação para saúde, que ai envolvia a horta também, mas realmente eu não sei como está. Eu imagino que esteja parado" (professor de Geografia das Escolas Particulares B e E). 
Os momentos de avaliação e planejamento para o próximo ano também acabam sendo prejudicados:

“(..) nunca teve um fechamento (...). Ai fica difícil porque a gente só tem este horário de HTPC para estar se reunindo e às vezes não dá tempo. Então, às vezes na hora do intervalo (...) A maioria das vezes o projeto acaba se perdendo" (professora de Ciências da Escola Estadual G).

De fato, somente duas das escolas selecionadas para a pesquisa declararam ter reservado horários para que os professores pudessem conversar, planejar, executar e avaliar suas atividades conjuntamente. A coordenadora e professora de Geografia da Escola Particular D dá mostra isso:

"Nós temos reuniões todas as terças-feiras. No início do ano elas já são planejadas (...) e nós decidimos as atividades em conjunto. (...) Existe toda uma programação para estar se discutindo as atividades, conteúdos e tudo mais. No final do ano a avaliação. O que fica, o que continua, o que muda para o próximo ano".

A falta de um momento adequado para o trabalho individual e integrado dos professores indiscutivelmente coloca entraves para que haja possibilidades concretas de ação e reflexão coletivas. Todos os depoimentos evidenciam dificuldades e carências e a necessidade de maiores investimentos e valorização da educação em nosso país. É evidente que o professor precise de apoio administrativo e tempo para preparar aulas, avaliar suas atividades, receber orientações, pesquisar e estudar.

\subsection{Os conteúdos programados e materiais didáticos}

A obrigação de "vencer" os conteúdos programados e de seguir o livro didático ou apostila adotada pela escola foi apontada pelos professores entrevistados como uma das dificuldades em se realizar atividades relacionadas à EA. Particularmente para os professores da rede privada de ensino esse é um grande obstáculo. As escolas particulares impõem um maior controle no ritmo e conteúdos trabalhados em sala de aula. Se as atividades ou projetos não estiverem planejados, os trabalhos com EA ficam prejudicados. Como observamos na fala da professora de Artes da Escola Particular C, que tenta encaixar projetos de EA nos espaços entre as apostilas: 
"Se não der esse espaço não tem como. Porque a gente tem que cumprir (...) a apostila. Você termina a apostila no último dia antes de terminar o bimestre já chegou a outra apostila. Mas nos bimestres que dá certo a gente sempre faz algum projeto, alguma coisa junto".

Porém, nem todo professor encontra dificuldades para estar trabalhando com a temática ambiental na escola particular. O professor de Geografia da Escola Particular E, ao compará-la com a Escola Particular B, onde também leciona, observa um espaço maior para seu trabalho:

“(...) a escola (...) tem um perfil diferente das outras escolas. Ela é bem democrática. Então, esse negócio da orientação, a escola faz discussão e a partir dessa discussão os professores vão fazendo as suas linhas de trabalho. No sentido da dinâmica ambiental, cada professor especialista tem o seu trabalho dentro da sua área. (...) a escola dá uma liberdade muito grande para a gente trabalhar. (...) A gente faz discussões, tem o conselho de escola..." .

Entre os professores das escolas estaduais existem aqueles que acreditam haver um espaço para trabalhos com a EA e aqueles, por outro lado, que encontram dificuldades em inserir a questão ambiental nos conteúdos das disciplinas. A professora de Ciências da Escola Particular B, que é coordenadora da Escola Estadual J, compara a liberdade que o professor da rede estadual tem em relação aos da rede particular:

"É porque no Estado não tem uma coisa assim fechada. O professor pode tratar esse tipo de assunto na hora que ele sentir necessidade e no particular também acontece, mas a matéria é mais fechada pelo fato de ser apostilada."

Já na fala da professora de Ciências da Escola Estadual B, notamos a preocupação com os conteúdos programados da sua disciplina:

“(...) eu também não quero deixar meu conteúdo de lado. (...) fica complicado porque Ciências são três aulas semanais e Biologia só duas. Então, já é difícil cumprir o conteúdo sem ter que desenvolver projetos e com projeto já restringe mais nosso tempo. Por exemplo, projetos de prevenção de DST - AIDS, gravidez - vêm para gente, de Ciências. Projetos de Educação Ambiental vêm para gente, o projeto do tabagismo vem para gente, saúde bucal também vem para gente e todo ano tem. Então, é muita coisa e é muito dificil trabalhar por muito tempo, fazer grandes coisas. Então, Educação Ambiental, como eu falei para você, eu costumo falar, mas não fazer grandes coisas, como projetos”. 
Observamos também uma preocupação dessa professora com o excesso de projetos que ela tem que estar trabalhando nas suas aulas. Fica claro que a EA tem que estar disputando espaço com os demais temas abordados pela professora, pois a temática ambiental na escola em que leciona é responsabilidade de Ciências. A professora de Ciências da Escola Estadual J vê a dificuldade que o professor tem para estar dividindo seu tempo entre o desenvolvimento dos projetos e os conteúdos da sua disciplina:

"Talvez um tempo maior para a gente estar acompanhando de perto. (...) Você está trabalhando este projeto, mas você tem conteúdo didático para dar".

Realmente, a elaboração e desenvolvimento de um projeto de EA acaba sendo um trabalho extra para os professores.

A falta de material didático direcionado para trabalhos com EA também foi levantada pelos entrevistados como uma dificuldade. Esse fato já tinha ficado evidente quando abordamos os recursos utilizados pelos professores em seus trabalhos de EA e agora é reafirmado pelos entrevistados como uma dificuldade para desenvolver trabalhos nessa temática. Como para a maioria dos professores o livro didático ainda é uma referência na sala de aula e nos trabalhos de EA, a pouca freqüência ou mesmo ausência de tópicos que abordem questões ambientais acaba transformando-se numa dificuldade:

"Eu acho que é mesmo essa questão de não estar tão forte ali no livro didático porque de uma maneira ou de outra a gente tem que dar uma seguida ali, a gente tem que usar. Então, eu acho que tem que ter em cada capitulo uma janelinha ali no livro falando alguma coisa sobre Educação Ambiental, para estimular mesmo, para o aluno desenvolver esse pensamento. (...) Eu acho que é a maior dificuldade porque isso ai cabe ao professor estudar, preparar sua aula e ver se é importante ser falado ou não, mas tendo ali no livro didático, mesmo que o professor não faça ou mesmo que o aluno fique meio disperso, mas na hora dele estudar tem uma referência ali para ele..." (professora de Ciências da Escola Particular F).

\subsection{Em relação à motivação e comprometimento}

A motivação, envolvimento e comprometimento de alunos e professores também são apontadas como dificuldades na incorporação da EA ao ensino formal, principalmente no que se refere ao desenvolvimentos de projetos. 
Alguns professores sentem que faltam consciência, vontade e envolvimento dos alunos nas atividades relacionadas à $\mathrm{EA}$ :

"O único problema de não ter dado certo nos anos anteriores é que a maioria da população ainda não está consciente disso. Eles acham que dá trabalho separar o papel para reciclagem, eles não entendem... não tem muita vontade mesmo. Eles até entendem que é importante, que é necessário, mas eles não querem ter trabalho nenhum. A gente já tentou colocar lixinhos em ordem nas salas (...) jogavam papel no chão, jogavam na caixinha errada... eu acho que o problema maior é esse" (professora de Ciências da Escola Estadual K).

"Eu acho que a maior dificuldade é a consciência consumista que eles têm. Que os estudantes têm, que trazem das famílias e tudo mais. Então, eles têm uma barreira muito grande para entender que os processos ambientais dependem deles e dependem justamente do posicionamento que eles vão ter em relação ao consumo (...). Não diria que é uma dificuldade, mas um desafio muito grande para o professor" (professor de Geografia das Escolas Particulares B e E).

"Tem também muitos alunos que acabam não se interessando pelos problemas (...) eles estão muitos acostumados com aulas. Se você não passa lição na lousa todo dia. Se eu faço uma discussão, como eu fiz com o tema do cigarro, eles me perguntam: Dona, você não vai dar nada? E não é um, são vários. E isto eu escuto também dos meus colegas quando vai dar alguma coisa diferente. E eu falo: eu estou dando uma coisa, só não estou passando na lousa. E quando eu peço formem grupos, que façam história em quadrinhos, façam uma discussão, e eles: você não vão dar nada? (...) os próprios pais quando olham o caderno dos alunos de $5^{a}$ série: a professora não deu nada hoje?"(professora de Ciências da Escola Estadual B).

Outros apontam a falta de envolvimento dos professores:

"Eu acho que falta é vontade mesmo. Eu acho que falta vontade de fazer alguma coisa pelo bem da coletividade. Porque quando o professor pensa 'ah, não ganho para isso', ele vai continuar fazendo o trabalho dele na sala de aula porque é diferente de você já ter as aulas preparadas, entendeu? Vinte anos que eu estou na sala de aula. Faz muito tempo que eu trabalho com ensino médio, as minhas aulas já estão na minha cabeça há muito tempo. É claro que eu preparo um texto, eu preparo uma avaliação (...) Mas, eu não preciso preparar minhas aulas todo dia. (...) Eles querem que os alunos sentem enfileirados, em silêncio, um olhando para nuca do outro e que sejam meros copiadores. E aquilo que ele, fala ele acha que é muito importante, que o aluno precisa saber. É importante para ele. Para o aluno isso não faz o menor sentido, porque ele tem tanta informação, até o aluno mais carente tem acesso a televisão, pelo menos, que é o meio de comunicação de massa. Ele tem acesso à informação que ele quiser. $O$ negócio é transformar essa informação em conhecimento para ele. E isso dá 
trabalho. Então, toda mudança exige que o professor também mude. E o professor não quer mudar” (professora de Português da Escola Estadual K).

Essa mesma professora acredita na importância do envolvimento de todos que formam a comunidade escolar:

“(...) Envolvimento de todo corpo docente, aliás, de todos os funcionários da escola, da direção, porque precisa, sabia? (...) Professores, alunos, serventes, pessoal que trabalha na merenda, na cantina (...). O máximo de gente que trabalha na escola possivel para a gente trazer para observar, para analisar, para conhecer (...)”.

\subsection{Em relação à formação dos professores}

Outra dificuldade levantada pelos professores entrevistados é em relação à sua formação acadêmica:

\footnotetext{
“(...) As vezes a gente quer trabalhar... Um grupo de professores quer trabalhar, mas a gente tem um professor de Matemática, Português que não tem muito conhecimento sobre o assunto e ele quer conhecer aquilo, mas a gente não tem essa... A gente não tem um ATP para auxiliar a gente, um assessor pedagógico... Uma capacitação sobre este tema, para esta levando os professores, para estar discutindo sobre isto... Para estar conhecendo o que tem de novo aí... Os trabalhos que já foram desenvolvidos... Ás vezes tem trabalhos ótimos que já foram desenvolvidos que a gente pode trazer para escola, adaptar, começar a desenvolver na escola e os professores não têm conhecimento sobre isto" (professora de Ciências da Escola Estadual E).
}

Como já discutimos anteriormente, a deficiência na formação dos professores é um dos fatores determinantes na incorporação da EA ao ensino formal. Os professores, principalmente aqueles das disciplinas que não são tradicionalmente ligadas às questões ambientais, apresentam muitas dificuldades em incluir a problemática ambiental nos conteúdos programados da suas disciplinas ou mesmo em desenvolver projetos ligados a esse tema. Realmente, a presença da EA no ensino formal é muito recente:

"Educação Ambiental é um tema (...) novo, eu acredito. Muitos professores não estão capacitados para trabalhar desta forma, desta maneira, com este tema. Eles encontram dificuldades para estar relacionando com o conteúdo deles (...) por questão de planejamento mesmo. (...) Ele quer trabalhar um projeto. Então 
ele para o que estava trabalhando para trabalhar o projeto. Ai ele vê que não vai dar conta daquele conteúdo que ele tinha se proposto trabalhar, então ele volta a trabalhar o conteúdo e deixa de lado o projeto. Talvez não consiga encaixar os projetos nos conteúdos que ele planejou. Eu acredito que seja isto. E até porque dá trabalho. (...) Não é um trabalho pontual é um trabalho contínuo. (...) Todo dia tentar relacionar com aquele conteúdo que você vai trabalhar, encontrar material para trabalhar com os alunos, promover uma discussão... Então isto acaba dando trabalho mesmo. Não tem espaço na escola, às vezes é muito corrido... Tem que aplicar uma prova, fazer isto e aquilo e acaba não dando tempo de você trabalhar o projeto. Então os professores acabam mesmo deixando de lado" (professora de Ciências da Escola Estadual E)

Assim, o medo de arriscar e de tentar mudar a maneira de lecionar acaba transformando-se em outro obstáculo nos trabalhos de EA:

"Dificuldades (...) de se juntar com outros professores mesmo. Para gente trabalhar deste tipo a gente precisa sair do nosso... daquela metodologia é... sempre daquele jeito... É dificil experimentar o novo porque muita coisa pode dar errado e as pessoas preferem não arriscar muitas vezes" (professor de Ciências da Escola Estadual E).

Em termos das dificuldades levantadas pelos professores com o trabalho de EA, alguns pontos chamam nossa atenção. Primeiramente, o fato de alguns professores alegarem não encontrar qualquer dificuldade nos trabalhos com EA ou, em outros casos, a pouca preocupação em refletir sobre tais dificuldades. Carvalho (1989) também se deparou com o mesmo fato. Para o autor existem duas maneiras possíveis para explicar esse fato: ou esses professores não conseguem "identificar e explicitar os entraves que a atual estrutura escolar lhes impõe" ou a incorporação da EA tem ocorrido sem que, em momento algum, haja uma reflexão das dificuldades que se impõe no desenvolvimento de trabalhos de EA. Como superar as barreiras existentes na educação escolar e da EA, em particular, se muitos professores não conseguem nem articular e expressar essas dificuldades? É necessário, primeiramente, conhecer a realidade escolar, para depois transformá-la, pois, conhecendo as "(...) contradições, compreender e negar essa realidade (...) e, ao mesmo tempo, ultrapassar esse estágio", pode-se "propor fins a atingir, prefigurar idealmente o ideal a ser alcançado, buscando-se condições objetivas e atuando para sua realização" (GONÇALVES, 1994, p. 475).

Outra questão que nos chamou a atenção foi que muitos dos problemas levantados pelos professores acabam evidenciando deficiências que são inerentes à própria estrutura da escola e, por 
conseqüência, prejudicam o desenvolvimento de trabalhos de EA. De fato, para Krasilchik (1986), as escolas contêm na própria estrutura elementos que podem dificultar ou mesmo impedir que a EA seja incorporada ao currículo escolar. Ainda segundo a autora, "alguns desses fatores independem do objeto da educação ambiental, pois perpassam por todo sistema escolar", como "professores sobrecarregados, classes superlotadas, falta de instalações adequadas, alunos mal alimentados, cansados" (p. 1960).

Todas essas dificuldades que os professores têm que enfrentar ao incorporar a EA nas suas práticas de ensino, fazem surgir atividades fragmentadas e descontextualizadas. Assim, mesmo que todas as escolas selecionadas para a pesquisa digam que trabalham com EA, o caráter de improviso e desconectado do currículo escolar e a falta de um compromisso com mudanças na relação sociedade - natureza ficam evidentes nas falas das professoras:

"A gente tem a apostila (...). A apostila é boa, mas eu tenho sempre que trazer vídeos. Essa parte de educação ambiental a gente vai mais no improviso, no falar..." (professora de Ciências da Escola Particular C).

“(...) eu tiro de algum lugar, um recorte ou alguma coisa, se dá para tirar xerox eu passo para todos, se não (...) passo um resumo na lousa ou às vezes eu comento com eles e peço para eles fazerem alguma coisa" (professora de Ciências da Escola Estadual J).

"Acho que em todas as escolas a gente tem esta dificuldade porque a gente não tem uma estrutura boa para trabalhar com isto. A gente não tem recursos para trabalhar porque a gente trabalha com alunos pobres. (...). Então a gente improvisa bastante, mas isto é bom porque a gente aprende a trabalhar com muitos materiais, tento improvisar" (professora de Ciências da Escola Estadual E).

Outra questão que nos chamou a atenção durante o levantamento das dificuldades de se trabalhar a EA na escola é a idéia de criação de uma disciplina de EA. Não tínhamos, inicialmente, a pretensão de investigar se entre os entrevistados havia os que acreditassem que a melhor maneira de inserir a EA no ensino formal seria através da criação de uma disciplina específica, por isso, no roteiro de entrevista nenhuma pergunta é destinada para abordar essa questão. Porém, ficou evidente, logo na primeira entrevista realizada, que essa ainda é uma idéia que alguns professores consideram viável. 
Acreditamos que a menção a criação de uma disciplina de EA é, em parte, uma conseqüência das dificuldades enfrentadas na sua incorporação ao currículo escolar. A fala da professora de Ciências da Escola Estadual J nos revela certa frustração com os trabalhos de EA:

"Porque fica uma coisa perdida, porque você começa a desenvolver um projeto, mas não consegue ver um resultado no final. Eu acho que a gente deveria ter uma disciplina mesmo ou sei lá, dividir ai os conteúdos porque é muito pouco (...) É interessante trabalhar com os temas transversais em todas as disciplinas, mas você tem que ter um profissional especializado. Porque eu posso ter mais facilidade de trabalhar esta questão da poluição porque eu fiz Biologia, estou mais em contato, mas o professor de Matemática até pode estar trabalhando de outra forma, mas não tem a bagagem. Eu acredito que o governo teria que estar investindo numa matéria, uma matéria que trabalhasse a questão ambiental mesmo. (...). Se não fica uma coisa muito de sala de aula e acaba se perdendo porque a gente não consegue um resultado efetivo mesmo".

O professor de Geografia da Escola Estadual F também se mostra frustrado com os trabalhos de EA e explica como deveria ser inserida a disciplina de EA no currículo escolar:

“Uma aula por semana ou duas de Educação Ambiental... Seria assim um ganho muito grande porque a pessoa que daria esta aula estaria mais preparada e poderia trabalhar projetos diversos com relação à preservação ambiental. (...) Nem que não pegasse todas as séries. Eu tenho um pensamento que depois de grande você não educa o cara, entendeu? Então eu acho que Educação Ambiental deveria ser entre $5^{\circ}$ e $6^{\circ}$ séries. (...) Porque depois que o cara fica grande e aprendeu a sujar, (...) a não cuidar, é difícil você mudar. Não digo que você não mude, mas é muito dificil. Agora, se você pega o garotinho na $5^{a}$ ou $6^{a}$ série você tem grande chance de formar um cidadão mais cuidadoso com o meio ambiente".

Para esse professor, a justificativa de se criar uma disciplina de EA é válida também porque acredita que quanto mais cedo a criança aprende melhores são os resultados. A coordenadora da Escola Particular F também partilha dessa idéia e diz que, embora a escola trabalhe com a EA em todos os ciclos de ensino, o trabalho de EA mais interessante é feito com as crianças:

"Eles trabalham, fazem hortinha, cuidam das plantas. E esse é um trabalho muito interessante. (...). Eu acho que mais cedo você colhe as plantinhas porque eles se tornam um agente multiplicador dentro da própria casa. (...) é interessante estar vendo isso desde pequenininho. A parte que a gente mais enfatiza. Não é que a gente não enfatiza o de $5^{a}$ a $8^{a}$ e de ensino médio, a gente enfatiza. Mas o mais importante para nós é que quanto menor a criança melhor a qualidade de ensino tem que ser voltada à educação ambiental". 
Já a coordenadora da Escola Particular B acredita que a EA deveria ser inserida através das disciplinas de Ciências:

"E seria interessante que existisse como disciplina, inserida como uma parte talvez na área de Ciências, com um conteúdo especifico. Houve uma época que existia ecologia. A gente trabalhava ecologia. Mas com todas essas mudanças de legislação deu uma parada, principalmente a rede particular”.

Em uma das escolas selecionadas para a pesquisa já houve a experiência de desenvolver uma disciplina de EA. A coordenadora da Escola Particular A nos conta como era essa disciplina:

“(...) trabalhava a questão, por exemplo, do respeito, da questão ética, um trabalho muito importante. Foi uma das coisas que fez com que a gente trouxesse essa disciplina na grade pelo formato da apresentação e da proposta que existia. E isso por que? Porque dava uma ênfase muito grande nos aspectos sociais das escolas, ético das relações. Então, num primeiro momento isso iria somar".

Porém, a escola percebeu que esse não era o melhor caminho:

“(...) essa experiência mostrou para gente que esse não é o caminho. A gente pensou em projetos numa outra dimensão. A gente entendeu que a forma como isso foi encaminhado não foi um caminho positivo. Pelo menos essa foi a nossa experiência (...) Porque a gente entendeu que educação ambiental não deve ser uma disciplina, tratada como disciplina. Tem grandes temas envolvendo educação e meio ambiente. E esses temas precisam ser cuidados, encaminhados, em outro formato que não necessariamente uma disciplina (...)”.

Infelizmente não pudemos ter muitos detalhes da experiência que essa escola teve em instituir uma disciplina de EA na sua grade.

Em suma, as dificuldades levantadas pelos professores entrevistados em relação aos trabalhos com a temática ambiental nos revelam os obstáculos que os atores que atuam no ambiente escolar devem enfrentar ao procurar incorporar a EA ao currículo escolar. Dificuldades essas que são próprias de um campo recente e em formação, como o da EA, onde ainda há uma busca para estruturação e consolidação de suas teorias e práticas. São também dificuldades que nos remetem às deficiências inerentes à instituição escolar, que impõe aos docentes um contexto desfavorável para seu trabalho, como professores sobrecarregados, a alta rotatividade de docentes, falta de recursos 
financeiros e estruturais inadequados, baixos salários, pouco de tempo para trabalhos em equipe, sistema de ensino fechado, etc. Porém, a despeito dessas dificuldades, podemos observar um grande esforço por parte dos educadores em incorporar a EA à educação escolar, através dos conteúdos programados de Ciências e Geografia, no desenvolvimento de projetos e também em atividades pontuais. Contudo, esse ainda é um processo que se mostra paralelo ao projeto político-pedagógico da escola, desenvolvido de maneira, isolada, descontínua e muitas vezes voluntária. De fato, a inclusão da EA nas práticas de ensino escolares ocorre ainda em um ambiente com uma "lógica disciplinar e linear da estrutura conceitual do currículo" (TRISTÃO, 2004, p. 129). É dentro dessa realidade que os atores escolares deverão vislumbrar os limites e potencialidades da $\mathrm{EA}$ e, assim, encontrar os caminhos para sua inserção. 


\section{CONSIDERAÇÕES FINAIS}

O homem pode refletir sobre si mesmo e colocar-se num
determinado momento, numa certa realidade: é um ser na
busca constante de ser mais e, como pode fazer esta auto-
reflexão, pode descobrir-se inacabado, que está em
constante busca. Eis aqui a raiz da educação.

Paulo Freire

Observarmos que as carências e as dificuldades em relação aos trabalhos com EA se fazem presentes tanto nas escolas estaduais quanto nas escolas particulares. Configura-se, dessa maneira, o mesmo contexto escolar desfavorável para a inserção da EA nas escolas das redes privadas e públicas de ensino, porém há certa inclinação de os cursos, capacitações e/ou projetos desenvolvidos por órgãos governamentais e empresariais estarem voltados para escolas da rede pública de ensino.

Identificamos, no presente trabalho, que as dificuldades na incorporação da EA no ensino fundamental nas escolas de Piracicaba são referentes à deficiência nas formações inicial e continuada dos professores, o que torna difícil o trabalho com temas ligados à questão ambiental, um campo complexo e recente, e pode levar a interpretações imediatistas, desprovidas de um entendimento multidimensional, crítico e político como tal questão exige. A falta de tempo e espaço adequado para reuniões de planejamento, estudo e pesquisa, individual e/ou coletivo, impõem ao trabalho docente um contexto onde não há diálogo e participação de todos nesse processo educativo, pois os horários reservados para reuniões mostraram-se insuficientes e conturbados. Os recursos materiais e metodológicos são escassos e até inexistentes, estando os trabalhos com EA sendo predominantemente apoiados em materiais inapropriados, como o livro didático, e desenvolvidos de maneira improvisada. A grade curricular é fechada, organizada por uma estrutura predominantemente disciplinar, o que pode atrelar os professores das escolas particulares e estaduais a conteúdos e prazos determinados e também dificultar o desenvolvimento do trabalho entre as disciplinas. Essas e outras dificuldades são inerentes à estrutura institucional e pedagógica da escola (KRASILCHIK, 1986), que reflete e até impossibilita que a EA seja inserida no ensino escolar de uma forma crítica e emancipatória, conforme defendemos. Assim, mesmo no caso de algumas escolas analisadas que desenvolvem projetos de modo mais contínuo, podemos perceber o quanto 
ainda a EA é trabalhada como uma atividade extracurricular, desvinculada do projeto políticopedagógico da escola.

A maneira com a EA está sendo inserida nas escolas de Piracicaba é similar as práticas de EA que vem sendo desenvolvidas em outros territórios escolares (BRÜGGER, 1998; CARVALHO, 2003, 1989; GRÜN, 1996; GUIMARÃES, 2003; LIMA, 1999; LOUREIRO, 2004). A EA está sendo incorporada nas escolas de Piracicaba de maneira fragmentada, estando presente em atividades desenvolvidas predominantemente por disciplinas cujos conteúdos são considerados "ambientais", como Ciências e Geografia, e direcionadas mais para séries iniciais do ensino fundamental. A visão da problemática ambiental situa-se dentro de uma visão simplista, superficial e restrita, onde os aspectos físicos e biológicos são enfatizados em detrimento dos aspectos social, político, cultural e econômico. As atividades de EA estão sendo desenvolvidas de maneira isolada do currículo escolar, conduzida como uma atividade extracurricular, não havendo a devida ligação entre os saberes sistematizados pela escola e outros saberes. Esse fato dificulta aos educandos e educadores o desenvolvimento de uma leitura crítica e complexa da questão ambiental. As abordagens ainda permanecem descontínuas e as atividades são desenvolvidas e iniciadas sem o compromisso de um fechamento, de avaliações e continuidade. Mesmo os professores entrevistados mais motivados e sensibilizados com as questões ambientais e/ou os professores que demonstram ter uma concepção mais crítica de educação, meio ambiente e de EA, acabam tendo as mesmas dificuldades dos seus colegas e, estando isolados e amarrados a um ambiente escolar pouco fértil para desenvolver um trabalho que se diferencia do tradicional, reproduzem o mesmo modelo de trabalhos com a temática ambiental que vem sendo convencionalmente trabalhado nas escolas, alinhando-se, portanto, mesmo sem querer, a uma EA Conservadora, Convencional e/ou Tradicional, ou seja, a uma EA que vem se revelando hegemônica, em que há:

O predomínio da visão fragmentária (simplista e reducionista) (...), que potencializa uma forte tendência ao desenvolvimento de ações isoladas, de forma pontual, voltada para o comportamento de cada indivíduo, descontextualizada o educando e o educador da realidade sócio-ambiental em que a escola está inserida (GUIMARÃES, 2003, p. 119).

Acreditamos que a maneira como a EA tem sido incorporada nas escolas, de forma pontual e doutrinária, pouco contribuirá para a construção de uma prática educativa que venha a ser transformadora, crítica e emancipatória, como propõem as correntes de educação e de EA mais 
progressistas. Os trabalhos da EA desenvolvidos ficam mais no nível das intenções do que propriamente na possibilidade de promover mudanças no currículo escolar. A EA agoniza na rotina escolar, em parte pela complexidade do campo e da dimensão da tarefa a que se propõe e também pela forma improvisada e desorganizada com que é trabalhada pelas escolas.

Para Guimarães $(2003,2004)$, os professores estão presos ao que o autor chama de armadilhas paradigmáticas, que os impedem de ir além de um EA Conservadora:

Produto e produtora de uma leitura de mundo e um fazer pedagógico, atrelado ao "caminho único" traçado pela racionalidade dominante da sociedade moderna e que busca ser inquestionável. É esse processo que vem gerando, predominantemente, ações educativas reconhecidas no cotidiano escolar como Educação Ambiental e que, por essa armadilha paradigmática na qual se aprisiona os professores, apresenta-se fragilizada em suas práticas pedagógicas. As práticas resultantes (por não saber diferente) tendem a reproduzir o fazer pedagógico da Educação tradicional, enebriando a perspectiva crítica e criativa do processo pedagógico, produzindo predominantemente na realidade escolar uma Educação Ambiental de caráter conservador (GUIMARÃES, 2003, p. 105).

Mesmo os professores que tentam fugir da perspectiva tradicional de ensino acabam também imprimindo em suas práticas um caráter tradicional, alimentando a visão hegemônica de EA. É nesse sentido que para Grün (1996) qualquer tentativa de promover a EA dentro contexto escolar sustentado pela concepção de mundo cartesiana-newtoniana dominante, produzirá uma pedagogia redundante, pois, procura alternativas dentro do próprio paradigma que pretende superar. Assim, ao invés de contribuir para as transformações que nos levam a uma nova ordem social, a escola serve como um dos instrumentos que mantém o modelo social vigente, uma vez que os atores escolares, estando presos às armadilhas paradigmáticas, sustentam e são sustentados pelo status quo (GUIMARÃES, 2003). Acreditamos que a EA viva um momento crítico, espremida entre a possibilidade de ser apenas mais um modismo dentro da educação escolar ou de impor-se concretamente como uma alternativa de mudança para a escola.

De que modo então os atores escolares podem fugir dessa EA que vem sendo trabalhada pelas escolas - fragmentada, superficial, isolada e descontínua - e construir uma proposta de EA que venha a contribuir para uma educação escolar que seja crítica, transformadora e emancipatória?

Para Guimarães (2003), é imprescindível um movimento de ruptura com a armadilha paradigmática que imobiliza educadores e educandos, uma vez que esta provoca e mantém "uma limitação compreensiva (...) em relação ao mundo complexo, que provoca uma incapacidade 
discursiva para lidar com a complexidade das questões ambientais" (VEIÉGAS, 2002 apud GUIMARÃES, 2003, p. 104-105). Lima (1999), abalizado pelas teorias educacionais progressistas, acredita que a construção de práticas educativas críticas e transformadoras podem ser consolidadas nas brechas e nas contradições próprias do sistema sócio-político vigente.

De certo que qualquer que seja o caminho seguido, ele será árduo e longo, o que pode muitas vezes nos trazer um sentimento de impotência diante de um quadro com tantas adversidades, levando-nos a agir somente dentro das possibilidades existentes. Para Gonçalves (1994), é esse quadro de imobilismo e "a falta de condições para se operacionalizar as mudanças idealizadas" que induzem as pessoas "à acomodação e à adaptação responsável pela manutenção e reprodução da situação caótica em que se encontra a educação brasileira” (p. 476). É nesse sentido que reforçamos que as mudanças na educação escolar devem ser almejadas dentro dos limites e potencialidades existentes no contexto escolar. As mudanças devem ser vislumbradas como parte integrante de um conjunto de outras práticas sociais que procuram transformar o modelo social vigente, na crença de que este modelo não se mostra social, econômico e ecologicamente sustentável.

Sabemos que os professores também são vítimas das péssimas condições de ensino que lhes são impostas e seria uma injustiça responsabilizá-los pelo estado em que se encontra o sistema educacional. É nesse sentido que acreditamos e defendemos que somente através de um pacto entre todos os atores que compõem o ambiente escolar será possível que a EA que acreditamos e defendemos seja devidamente incorporada à educação escolar e tenhamos, enfim, uma educação básica de qualidade comprometida com a realidade socioambiental. Um pacto que extrapole os muros da escola e que convide a sociedade a participar desse processo. Não existem fórmulas prontas, mágicas ou instantâneas, mas acreditamos que através de parcerias concretas - diferentes das parcerias que chegam com soluções fechadas e prontas - entre a escola, a universidade, a comunidade, as instituições governamentais e as não-governamentais, poderemos construir uma proposta político-pedagógica de EA. Embora o contexto escolar seja demarcado por dificuldades, deficiências e limitações, que muitas vezes arrastam os educadores e educandos numa prática educativa tradicional, defendemos a construção de uma proposta de EA orientada pelos pilares discutidos no capítulo 2 e, portanto, uma prática educativa que seja comprometida com a transformação social, procurando imprimir ações pedagógicas que sejam coerentes com os princípios em que se apóia: política, participativa e democrática; em busca de uma nova ética e novos saberes; de caráter contínuo e permanente e com uma abordagem inter e transdisciplinar. 
O desenvolvimento de projetos certamente é uma maneira interessante e viável de se trabalhar com EA dentro da escola, mas é preciso ir além e possibilitar que a EA, de fato, conquiste seu espaço e esteja conectada com a proposta político-pedagógica da escola. Assim, canais de diálogos precisam ser abertos e institucionalizados na escola, reaproximando educadores de educandos, escola da comunidade, saberes sistematizados de saberes populares, cognitivo do afetivo, cultura da natureza, etc. É imprescindível formar equipes de docentes, coordenadores e diretores e que esses atores tenham espaço e tempo adequados para discutir, refletir, planejar, programar, pesquisar e estudar conjunta e individualmente. É imprescindível, ademais, que professores e alunos trabalhem juntos nas (re)construções dos conhecimentos, construindo uma prática educativa dinâmica, com uma postura de pesquisadores, e em sintonia com o mundo que os rodeia (ligando local-global). Enfim, buscando uma práxis educativa que dê instrumentos aos indivíduos, educandos e educadores, para que sejam capazes de compreender a realidade socioambiental em sua multidimensionalidade, criando-se uma postura crítica e ativa diante dos novos desafios ambientais e para, assim, transformar o mundo.

Em suma, as propostas de EA, que nascem dentro do modelo de paradigma moderno, não poderão ser muito diferentes das propostas que existem atualmente nas escolas. Reafirmamos a crença de que o trabalho da incorporação da EA ao currículo escolar é também o trabalho da construção de uma educação escolar de qualidade, uma vez que possibilita a ruptura com a armadilha paradigmática que permeia o ambiente escolar. A EA fomenta e resgata as dimensões que foram sendo sufocadas e esquecidas pela educação tradicional e, no movimento de recuperação e recontextualização dessas dimensões, alinha a educação escolar em um cenário de crise socioambiental, juntando-se assim o processo que busca repensar a relação entre os indivíduos e desses com a natureza.

Finalizamos esse trabalho com a frase de uma das professoras entrevistadas, que, resumidamente, ilustra o desejo de todos aqueles que estão envolvidos com a construção de uma educação escolar de qualidade e com a transformação da sociedade: "Eu não vejo outra saída para a escola pública se não for a mudança" (professora de Português da Escola Estadual K). 


\section{REFERÊNCIAS}

ANDRÉ, M.E.D.A. Texto, contexto e significados: algumas questões na análise de dados qualitativos. Cadernos de Pesquisa, São Paulo, n. 45, p. 66-71, maio 1983.

. A pesquisa no cotidiano escolar. In: FAZENDA, I. (Org.). Metodologia da pesquisa educacional. São Paulo: Cortez, 1989. cap. 3, p. 35-45.

. Pesquisa em educação: desafios contemporâneos. Pesquisa em Educação Ambiental:

Abordagens Epistemológicas e Metodológicas, São Carlos, v. 1, n. 1, p. 43-58, jul./dez 2006.

AZANHA, J.M.P. Uma idéia de pesquisa educacional. São Paulo: Edusp, 1992. 201 p.

BARCELOS, V. "Mentiras" que parecem "verdades: (re)pensando a educação ambiental no cotidiano da escola. In: ZAKRZEVSKI, S.B. A educação ambiental na escola: abordagens conceituais. Erechim: Edifapes, p. 82-89, 2003. Disponível em:

$<$ http://www.reasul.org.br/mambo/files/cadernos\%20de\%20EA\%20URI\%202003.pdf $>$. Acesso em: 12 jun. 2006.

BARDIN, L. Análise de conteúdos. Tradução de L.A. Reto e A. Pinheiros. Lisboa: Edições 70, $1991.225 \mathrm{p}$.

BRASIL. Ministério da Educação. Secretaria de Educação Continuada, Alfabetização e Diversidade. Educação Ambiental: aprendizes de sustentabilidade. Brasília, 2007b. (Cadernos Secad, 1). Disponível em: $<$ http://www.jornaldomeioambiente.com.br/JMAtxt_importante/caderno_educacao_ambiental_26.02.pdf $>$. Acesso em: 27 jul. 2007.

BRASIL. Ministério da Educação. Secretaria de Ensino Fundamental. Panorama da educação ambiental no ensino fundamental. Brasília, 2001. Disponível em:

$<$ http://portal.mec.gov.br/secad/arquivos/pdf/educacaoambiental/panorama.pdf $>$. Acesso em: 12 jun. 2006.

BRASIL. Ministério da Educação. Ministério do Meio Ambiente. Conferência Nacional de Educação Ambiental, 1997, Brasília. Disponível em:

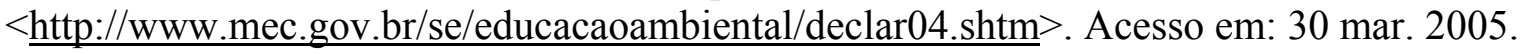

BRASIL. Ministério da Educação. Ministério do Meio Ambiente. Instituto Nacional de Estudos e Pesquisas Educacionais Anísio Teixeira. Mais de 70\% dos alunos do ensino fundamental têm Educação Ambiental. Brasília, 2000. Disponível em:

$<$ http://www.inep.gov.br/imprensa/noticias/censo/escolar/news02 05.htm>. Acesso em: 24 ago. 2006. 
BRASIL. Ministério da Educação. Ministério do Meio Ambiente. Órgão Gestor da Política Nacional da Educação Ambiental. Mapeamento da Educação Ambiental em Instituições Brasileiras de Educação Superior: elementos para políticas públicas. Brasília: Secad; MEC, 2007a. (Série de Documentos Técnicos, 12). Disponível em: http://portal.mec.gov.br/secad/arquivos/pdf/educacaoambiental/dt12.pdf. Acesso em: 29 maio 2007.

BRÜGGER, P. Visões estreitas na educação ambiental. Ciência Hoje, Rio de Janeiro, v. 24, n. 141, p. $62-65,1998$.

BURNHAM, T.F. Educação ambiental e reconstrução do currículo escolar. Cadernos CEDES, Campinas, v. 29, p. 21-30. 1993.

CARVALHO, I.C.M. Territorialidades em lutas: uma análise dos discursos ecológicos. Brasília: Secretaria do Meio Ambiente, Instituto Florestal, 1991. 56 p. (Série Registros, 9).

. Movimentos sociais e políticas de meio ambiente: a educação ambiental aonde fica? In: SORRENTINO, M.; TABANEZ, R; BRAGA, T. (Org.). Cadernos do III Fórum de educação ambiental. São Paulo: Gaia, 1995. p. 58-62.

. As transformações na cultura e o debate ecológico: desafios políticos para a Educação Ambiental. In: PADUA, S.M.; TABANEZ, M.F. (Org.) Educação ambiental: caminhos trilhados no Brasil. Brasília, 1997. 283 p.

. A invenção ecológica: narrativas e trajetórias da educação ambiental no Brasil. 2.ed. Porto Alegre: Editora da UFRGS, 2002a. 229 p.

. O "ambiental" como valor substantivo: uma reflexão sobre a identidade da EA. In: SAUVÉ, L.; SATO, M. Textos escolhidos em Educação ambiental: de uma América à outra. Montreal, Publications ERE-UQAM, 2002b. p. 85-90. Disponível em: <http://groupsbeta.google.com/group/LUSOFONIA>. Acesso em: 24 maio 2005.

. Qual educação ambiental? Elementos para um debate sobre educação ambiental popular e extensão rural. In: ZAKRZEVSKI, S.B. A educação ambiental na escola: abordagens conceituais. Erechim: Edifapes, 2003. p. 55-62. Disponível em: $<$ http://www.reasul.org.br/mambo/files/cadernos\%20de\%20EA\%20URI\%202003.pdf $>$. Acesso em: 12 jun. 2006.

. Educação ambiental crítica: nomes e endereçamentos da educação. In: LAYRARGUES, P.P. (Org). Identidades da educação ambiental brasileira. Brasília: Ministério do Meio Ambiente, 2004. p. 13-24.

. Discutindo a Educação ambiental a partir do diagnóstico em quatro ecossistemas no Brasil. Educação \& Pesquisa, São Paulo, v. 31, n. 2, p. 301-313, maio/ago.2005. Disponível em: $<$ http://www.scielo.br/scielo.php/script sci serial/lng pt/pid 0100-1574/nrm iso $>$. Acesso em: 25 maio 2006. 
CARVALHO, L.M. A temática ambiental e a Escola de $1^{\circ}$ Grau. 1989. 286 p. Tese (Doutorado em Educação) - Faculdade de Educação, Universidade de São Paulo, São Paulo, 1989.

. A educação ambiental e a formação de professores. In: BRASIL. Ministério da Educação. Secretaria de Ensino Fundamental. Panorama da educação ambiental no ensino fundamental. Brasília, 2001. p. 55-64. Disponível em:

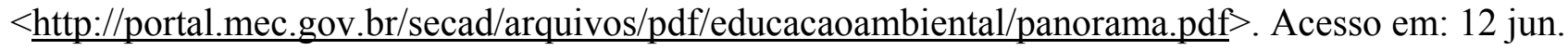
2006.

. A temática ambiental e o processo educativo: dimensões e abordagens. In: CINQUETTI, H.C.S.; LOGAREZZI, A. (Org.). Consumo e resíduo: fundamentos para o trabalho educativo. São Carlos: EDUFSCAR, 2006. cap. 1, p.19-39.

CASCINO, F. Educação ambiental: eixos teórico para uma reflexão curricular. In: CASCINO, F.; JACOBI, P.; OLIVEIRA, J.F. (Org.). Educação, meio ambiente e cidadania: reflexões e experiências. São Paulo: SMA; CEAM, 1998. p. 15-23.

CRESPO, S. Educar para a sustentabilidade: a educação ambiental na agenda 21. In: NOAL, F.O.; REIGOTA, M.; BARCELOS, V.H.L. (Org.). Tendências da educação ambiental. Santa Cruz do Sul: EDUNISC, 1998. p. 211-255.

CRUZ NETO, O. O trabalho de campo como descoberta e criação. In: In: MINAYO, M.C.S. (Org.) Pesquisa social: teoria, método e criatividade. 22.ed. Petrópolis: Ed. Vozes, 2003. cap. 3, p. 51-66.

DEMO, P. Educar pela pesquisa. 4.ed. Campinas: Autores Associados, 2002. 129 p. (Coleção educação contemporânea).

DESLANDES, S.F. A construção do projeto de pesquisa. In: MINAYO, M.C.S. (Org.). Pesquisa social: teoria, método e criatividade. 22.ed. Petrópolis: Ed. Vozes, 2003. cap. 2, p. 31-50.

DIAS, G.F. Os quinze anos da educação ambiental no Brasil: um depoimento. Em Aberto, Brasília, v. 10, n. 49, p. 3-14, jan./mar. 1991.

. Elementos para capacitação em educação ambiental. Ilhéus: Editus, 1999. 189 p.

DIESEL, V. Educação ambiental: um tema démodé? Ciência \& Ambiente. Santa Maria, n. 8, p. 35 52, 1994.

FAZENDA, I.C.A. A questão da interdisciplinaridade no ensino. Educação \& Sociedade, Campinas, v. 27, p. 113-121, 1987.

FOLADORI, G. O desenvolvimento sustentável e a questão dos limites físicos. In: Limites do desenvolvimento sustentável. Tradução de M. Manoel. Campinas: Ed. da Unicamp. 2001. cap. 5, p. 101-140.

FRANCO, M.C. Educação ambiental: uma questão ética. Cadernos CEDES, Campinas, v. 29, p. 11-20, 1993. 
FREIRE, P. Educação e mudança. Tradução de M. Gadotti e L. L. Martin. Rio de Janeiro: Paz e Terra, 1983. 79 p. (Coleção Educação e Comunicação, 1). 1996. $148 \mathrm{p}$.

Pedagogia da autonomia: saberes necessário à prática educativa. São Paulo: Paz e Terra, $2002.176 \mathrm{p}$.

Ação cultural para a liberdade e outros escritos. 10.ed. Rio de Janeiro: Paz e Terra, .Pedagogia do oprimido. 42.ed. Rio de Janeiro: Paz e Terra, 2005. 213 p.

FREITAG, B. Escola, estado e sociedade. 4.ed. São Paulo: Moraes, 1980. 142 p. (Coleção Educação Universitária).

GIL, A.C. Métodos e técnicas da pesquisa em educação ambiental. In: PHILIPPI JÚNIOR, A.; PELICIONI, M.C.F. Educação ambiental e sustentabilidade. Barueri: Monole, 2005. p. 577-597. (Coleção Ambiental, 3).

GOLDENBERG, M A arte de pesquisa: como fazer pesquisa qualitativa em Ciências Sociais. 4ed. Rio de Janeiro: Record, 2000.

GONÇALVES, C.W.P. Os (des) caminhos do meio ambiente. 11.ed. São Paulo: Contexto, 2004. 138 p. (Temas Atuais).

GONÇALVES, F.S. Interdisciplinaridade e construção do conhecimento: concepção pedagógica desafiadora. Educação \& Sociedade, Campinas, n. 49, p.468-485, dez. 1994

GRÜN, M. Uma discussão sobre valores éticos em educação ambiental. Educação \& Realidade, Porto Alegre, v. 19, n. 2, p. 171-198, jul./dez. 1994.

Ética e educação ambiental: a conexão necessária. 5.ed. Campinas: Papirus, 1996. 120 p. (Coleção Magistério: Formação e Trabalho Pedagógico).

GUERRA, A.F.S.; GUIMARÃES, M. Educação ambiental no contexto escolar: questões levantadas no GDP. Pesquisa em Educação Ambiental, São Carlos, v. 2, n. 1, p. 155-166, jan./jun. 2007.

GUIMARÃES, M. A dimensão ambiental na educação. Campinas: Papirus, 1995. 107 p. (Coleção Magistério: Formação e Trabalho Pedagógico).

Educadores ambientais em uma perspectiva crítica: reflexões em Xerém. 2003. 168 p. Tese (Doutorado em Ciências Sociais) - Instituto de Ciências Humanas, Universidade Federal Rural do Rio de Janeiro, Rio de Janeiro, 2003.

. Educação ambiental crítica. In: LAYRARGUES, P.P. (Org.). Identidades da educação ambiental brasileira. Brasília: Ministério do Meio Ambiente, 2004. p. 25-34.

HAGUETTE, T.M. Metodologias qualitativas na sociologia. Rio de Janeiro: Vozes, 1992. 224 p. 
INSTITUTO BRASILEIRO DE GEOGRAFIA E ESTATÍSTICA. Ensino - matrículas, docentes e rede escolar 2006 Disponível em: <http://www.ibge.gov.br/home/>. Acesso em: 22 jun. 2007.

JACOBI, P.R. Educação ambiental: o desafio da construção de um pensamento crítico, complexo e reflexivo. Educação \& Pesquisa, São Paulo, v. 31, n. 2, p. 233-250, 2005. Disponível em:

$<$ http://www.scielo.br/scielo.php?script $=$ sci serial\&pid=1517-9702\&lng=en\&nrm=iso $>$. Acesso em:

17 fev. 2006.

KRASILCHIK, M. Educação ambiental na escola brasileira - passado, presente e futuro. Ciência e Cultura, Rio de Janeiro, v. 38, n. 12, p. 1958-1961, 1986.

. Educação ambiental. Ciência \& Ambiente. Santa Maria, n. 8, p. 71-90, 1994.

. Pesquisa em educação ambiental: tendências e perspectivas. Educação: Teoria e Prática. Rio Claro, v. 9, n.16/17, p. 43-46, jan./dez. 2001

LAYRARGUES, P.P. (Re) Conhecendo a educação ambiental brasileira. In: LAYRARGUES, P.P. (Org.). Identidades da educação ambiental brasileira. Brasília: Ministério do Meio Ambiente, 2004. p. 7-12.

LEFF, E. Educação ambiental e desenvolvimento sustentável. In: REIGOTA, M. Verde cotidiano: o meio ambiente em discussão. Rio de Janeiro: DP\&A, 2001. p. 111-129.

240 p.

. Epistemologia ambiental. Tradução de S. Valenzuela. 2.ed. São Paulo: Cortez, 2002.

. A crise ambiental é um problema do conhecimento. [Entrevista a L.Lopes]. Jornal do Brasil Ecológico, Belo Horizonte, ano 5, n. 64, p. 14-17, maio 2007.

LIBÂNEO, J.C. Democratização da escola pública: a pedagogia crítico-social dos conteúdos. 16.ed. São Paulo: Ed. Lolyola, 1999. 149 p. (Coleção Educar).

LIMA, G.F.C. O debate da sustentabilidade na sociedade insustentável. Política \& Trabalho, João Pessoa, n. 13, p. 201-222, 1997. Disponível em: < http://www.geocities.com/ptreview/13-lima.html $>$. Acesso em: 21 nov. 2005.

. Questão ambiental e educação: contribuições para o debate. Ambiente \& Sociedade, Campinas, ano 2, n. 5, p. 135-153, 1999.

. Crise ambiental, educação e cidadania: os desafios da sustentabilidade emancipatória. In:

LOUREIRO, C.F.B.; LAYRARGUES, P.P.; CASTRO, R.S. (Org.). Educação ambiental: repensando o espaço da cidadania. 2.ed. São Paulo: Cortez, 2002. p. 109 - 141. 
. O discurso da sustentabilidade e suas implicações para a educação. Ambiente \&

Sociedade, Campinas, v. 6, n. 2, p. 99-119, jul./dez. 2003. Disponível em:

$<\mathrm{http}: / /$ www.scielo.br/scielo.php?script=sci_arttext\&pid=S1414753X2003000300007\&lng=en\&nrm $=$ iso $>$. Acesso em: 25 jun. 2006.

. Educação, emancipação e sustentabilidade: em defesa de uma pedagogia libertadora para a educação ambiental. In: LAYRARGUES, P.P. (Org.). Identidades da educação ambiental brasileira. Brasília: Ministério do Meio Ambiente, 2004. p. 85-112.

. Formação e dinâmica do campo da educação ambiental no Brasil: emergências, identidades, desafios. 2005. 207 p. Tese (Doutorado em Sociologia) - Instituto de Filosofia e Ciências Humanas, Universidade de Campinas, Campinas, 2005.

LOUREIRO, C.F.B. Educação ambiental e movimentos sociais na construção da cidadania ecológica e planetária. In: LOUREIRO, C.F.B.; LAYRARGUES, P.P.; CASTRO, R.S. (Org.).

Educação ambiental: repensando o espaço da cidadania. 2.ed. São Paulo: Cortez, 2002. p. 69 - 98.

. A educação ambiental como prática social contextualizada. In: LOUREIRO, C.F.B. (Org.). Cidadania e meio ambiente. Salvador: Centro de Recursos Ambientais, 2003. p. 86-93.

.Trajetórias e fundamentos da educação ambiental. São Paulo: Cortez, 2004a. 176 p.

.Educação ambiental transformadora. In: LAYRARGUES, P.P. (Org.). Identidades da educação ambiental brasileira. Brasília: Ministério do Meio Ambiente, 2004b. p. 65-84.

.Complexidade e dialética: contribuições à práxis política e emancipatória em educação ambiental. Educação \& Sociedade, Campinas, v. 27, n. 94, p. 131-152, jan./abi. 2006. Disponível em: $<$ http://www.scielo.br/scielo.php/script_sci_serial//ng_pt/pid_0101-7330/nrm iso $>$. Acesso em: 25 jun. 2007.

LÜDKE, M. Como anda o debate sobre metodologias quantitativas e qualitativas na pesquisa em educação. Cadernos de Pesquisa, São Paulo, n. 64, p. 61-63, fev.1988.

LÜDKE, M.; ANDRÉ, M.E.D. A pesquisa em educação: abordagens qualitativas. São Paulo: EPU, 1986. $112 \mathrm{p}$.

MARTINS, E.F.; GUIMARÃES, G.M.A. As concepções de natureza nos livros didáticos de ciências. Ensaio - Pesquisa em Educação em Ciências, Belo Horizonte, v. 4, n. 2, nov. 2002. Disponível em: $<$ http/www.fae.ufmg.br/ensaio>. Acesso em: 04 set. 2006.

MATSUSHIMA, K. Dilema contemporâneo e educação ambiental: uma abordagem arquetípica e holística. Em Aberto, Brasília, v. 10, n. 49, p. 15-33, jan./mar.1991.

MEDINA, N.M. Breve histórico da educação ambiental. In: PADUA, S.M.; TABANEZ, M.F. (Org.). Educação ambiental: caminhos trilhados no Brasil. Brasília: Editora, 1997. cap. 21, p. 257269. 
. Formação de multiplicadores para educação ambiental. Revista Eletrônica do Mestrado

de Educação Ambiental, Carreiros, v. 1, jul./ago. 1999. Disponível em:

$<$ hhtp://www.fisica.furg.br/mea/remae/index2html . Acesso em: 11 out. 2006.

. A formação dos professores em educação fundamental. In: BRASIL. Ministério da

Educação. Secretaria de Ensino Fundamental. Panorama da educação ambiental no ensino fundamental. Brasília, 2001. p. 17-24. Disponível em:

$<$ http://portal.mec.gov.br/secad/arquivos/pdf/educacaoambiental/panorama.pdf $>$. Acesso em: 12 jun. 2006.

MEIRA, P.; SATO, M. Só os peixes mortos não conseguem nadar contra a correnteza. Revista de Educação Pública, Mato Grosso, v. 14, n. 25, 2005. No prelo. Disponível em:

$<$ http://www.ufmt.br/revista/revista.html $>$. Acesso em: 24 jun. 2006.

MENDONÇA, P.R. Educação ambiental como política pública: avaliação dos parâmetros em ação - meio ambiente na escola. 2004. Dissertação (Mestrado em Desenvolvimento Sustentável) - Centro de Desenvolvimento Sustentável, Universidade de Brasília, Brasília, 2004. Disponível em:

$<$ http://inep.gov.br/pesquisa/bbeonline/lista.asp?cod=146699\&Assunto=FORMA $\%$ C3\%83\%E2\%80 $\% \mathrm{~A} 1 \% \mathrm{C} 3 \% 83 \% \mathrm{C} 6 \% 92 \mathrm{O}+\mathrm{CONTINUADA \& Doc}=\mathrm{M} \& \mathrm{P}=0 \& \mathrm{nl}=20>$. Acesso em: 01 jul. 2006.

MEYER, M.A.A. Educação ambiental: uma proposta pedagógica. Em Aberto, Brasília, v. 10, n. 49, p. 41-46, 1991. 70,1994

. Educação ambiental e (des)envolvimento. Ciência \& Ambiente, Santa Maria, n. 8, p. 53-

.Reflexões sobre o panorama da educação ambiental no ensino formal. In: BRASIL. Ministério da Educação. Secretaria de Ensino Fundamental. Panorama da educação ambiental no ensino fundamental. Brasília, 2001. p. 89-92. Disponível em:

$<$ http://portal.mec.gov.br/secad/arquivos/pdf/educacaoambiental/panorama.pdf $>$. Acesso em: 12 jun. 2006.

MINAYO, M.C.S. Ciência, técnica e arte: o desafio da pesquisa social. In: social: teoria, método e criatividade. 22.ed. Petrópolis: Ed Vozes, 2003. p. 9-29. . (Org.). Pesquisa

MINAYO, M.C.S.; SANCHES, O. Quantitativo-qualitativo: oposição ou complementaridade? Cadernos de Saúde Pública, Rio de Janeiro, v. 9, n. 3, p. 239-262, jul./set. 1993.

MORIN, E. O método: 1. A natureza da natureza. 2 .ed. Porto Alegre: Ed Publicações EuropaAmérica, [19--]. 363 p.

. Ciência com consciência. Tradução de M.D. Alexandre e M.A.S. Dória. Rio de Janeiro: Bertrand Brasil, 1996. 344 p.

.Os sete saberes necessários à educação do futuro. 8.ed. São Paulo: Cortez; Brasília: UNESCO, 2003. $118 \mathrm{p}$. 
NOAL, F. A interdisciplinaridade como possibilidade metodológica e como vocação da educação ambiental. In: ZAKRZEVSKI, S.B. A educação ambiental na escola: abordagens conceituais. Erechim: Edifapes, 2003. p. 71-78. Disponível em: $<$ http://www.reasul.org.br/mambo/files/cadernos\%20de\%20EA\%20URI\%202003.pdf $>$. Acesso em: 12 jun. 2006.

REIGOTA, M. Educação ambiental: fragmentos de sua história no Brasil. In: NOAL, F.O.; REIGOTA, M.; BARCELOS, V.H.L (Org.). Tendências da educação ambiental. Santa Cruz do Sul: EDUNISC, 1998. p. 11-25.

. Meio ambiente e representação social. 4.ed. São Paulo, Cortez, 2001. 87 p.

(Questões da Nossa Época, 41).

RODRIGUES, N. Educação: da formação humana à construção do sujeito ético. Educação \& Sociedade, Campinas, v. 22, n. 76, p. 232-257, out. 2001. Disponível em:

$<$ http://www.scielo.br/scielo.php $>$. Acesso em: 21 abr. 2006.

RUSCHEINSKY, A. Meio ambiente e percepção do real: os rumos da educação ambiental nas veias das ciências sociais. Revista Eletrônica Mestrado em Educação Ambiental, Carreiros, v. 7, p. 2644, out./dez. 2001. Disponível em: <http://www.remea.furg.br/>. Acesso em: 23 abr. 2007.

SÁ, L.M. Pertencimento. In: FERRARO JÚNIOR, L.A. (Org.). Encontros e caminhos: formação de educadoras (es) ambientais e coletivos educadores. Brasília: MMA, Diretoria de Educação Ambiental, 2005. p. 247-256.

SANTOS, B.S. Um discurso sobre as Ciências na transição para uma ciência pós-moderna. Estudos Avançados, São Paulo, v. 2, n. 2, p. 46-71, 1988.

SANTOS, L.L.C.P. Políticas públicas para o ensino fundamental: parâmetros curriculares nacionais e sistema nacional de avaliação (SAEB). Educação \& Sociedade, Campinas, v. 23, n. 80, p. 346367, set. 2002. Disponível em: $<$ http://www.scielo.br/scielo.php/script_sci_serial/lng_pt/pid_01001574/nrm iso $>$. Acesso em: 16 nov. 2006.

SATO, M. Educação para o ambiente amazônica. 1997. Tese (Doutorado em Ciências, área de concentração em Ecologia e Recursos Naturais) - Centro de Ciências Biológicas e da Saúde, Universidade Federal São Carlos, São Carlos, 1997. Disponível em:

$<$ http://www2.ufscar.br/interface_frames/index.php?link=http://www.bco.ufscar.br>. Acesso em: 14 abr. 2007.

. Formação em educação ambiental - da escola à comunidade. In: BRASIL. Ministério da Educação. Secretaria de Ensino Fundamental. Panorama da educação ambiental no ensino fundamental. Brasília, 2001. p. 7-16. Disponível em: $<$ http://portal.mec.gov.br/secad/arquivos/pdf/educacaoambiental/panorama.pdf $>$. Acesso em: 12 jun. 2006. 
SAUVÉ, L. Educação ambiental e desenvolvimento sustentável: uma análise complexa. Revista de Educação Pública, Mato Grosso, n. 10, jul./dez. 1997. Disponível em:

$<$ http://www.ufmt.br/revista/revista.html >. Acesso em: 24 out. 2006.

. Educação ambiental: possibilidades e limitações. Educação e Pesquisa, São Paulo, v. 31, n. 2, p. 317-322, maio/ago. 2005a. Disponível em:

$<$ http://www.scielo.br/scielo.php? script=sci serial\&pid=1517-9702\&lng=en\&nrm=iso $>$. Acesso em: 26 maio 2006.

. Uma cartografia das correntes em educação ambiental. In: SATO, M.; CARVALHO, I.C.M. (Org.). Educação ambiental: pesquisa e desafios. Porto Alegre: Artmed, 2005b. cap. 1, p. 17-44.

SAVIANI, D. Escola e democracia. 8.ed. São Paulo: Cortez: Autores Associados, 1985. 96 p.

. Educação: seu papel histórico. In: SIMPÓSIO MUNICIPAL DE EDUCAÇÃO, 6. SIMPÓSIO REGIONAL DE EDUCAÇÃO, 3., 1988, Caxias do Sul. Caxias do Sul: Secretaria Municipal de Educação e Cultura, 1988. s/p.

. Pedagogia histórico-crítica: primeiras aproximações. 7.ed Campinas: Autores Associados, 2000. 158 p. (Coleção Polêmica do Nosso Tempo, 40).

SEGURA, D.S.B. Educação ambiental na escola pública: da curiosidade ingênua à consciência crítica. São Paulo: Annablume; Fapesp, 2001. 214 p.

SORRENTINO, M. De Tbilisi a Thessaloniki: a educação ambiental no Brasil. In: QUINTAS, J.S. (Org.) Pensando e praticando a educação ambiental na gestão do meio ambiente. Brasília: Ed. IBAMA, 2000. p.107-114.

. Reflexões sobre o panorama da educação ambiental no ensino formal. In: BRASIL. Ministério da Educação. Secretaria de Ensino Fundamental. Panorama da educação ambiental no ensino fundamental. Brasília, 2001. p. 39-41. Disponível em:

$<$ http://portal.mec.gov.br/secad/arquivos/pdf/educacaoambiental/panorama.pdf.. Acesso em: 12 jun. 2006.

SORRENTINO, M.; TRAJBER, R.; MENDONÇA, P.; FERRARO JÙNIOR, L.A. Educação ambiental como política pública. Educação \& Pesquisa. São Paulo, v. 31, n. 2, p. 285-299, 2005. Disponível em: $<$ http://www.scielo.br/scielo.php?script=sci_serial\&pid=15179702\&lng=en\&nrm=iso $>$. Acesso em: 19 jul. 2007.

TOZONI-REIS, M.F.C. Formação dos educadores ambientais e paradigmas em transição. Ciência \& Educação, Bauru, v. 8, n. 1, p. 83-96, 2002. Disponível em:

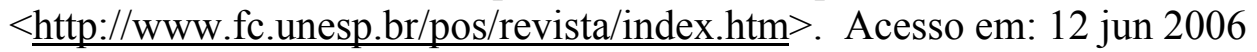

.Pesquisa em educação ambiental na universidade: produção de conhecimentos e ação educativa. In: TALAMONI, J.L.B.; SAMPAIO, A.C. (Org.). Educação ambiental: da prática pedagógica à cidadania. São Paulo: Escrituras Editora, 2003. p .9-19. 
. Educação ambiental: natureza, razão e história. Campinas: Autores Associados, 2004. 170 p. (Coleção Educação Contemporânea).

. Pesquisa-ação: compartilhando saberes; pesquisa e ação educativa ambiental. In:

FERRARO JÚNIOR, L.A. (Org). Encontros e caminhos: formação de educadoras (es) ambientais e coletivos educadores. Brasília: MMA, Diretoria de Educação Ambiental, 2005. p. 267-276.

TRISTÃO, M. A educação ambiental na formação de professores: redes de saberes. São Paulo: Annablume; Vitória, 2004. 236 p.

. Tecendo os fios da educação ambiental: o subjetivo e o coletivo, o pensado e o vivido. Educação \& Pesquisa, São Paulo, v. 31, n. 2, p. 251-264, maio/ago. 2005. Disponível em: $<$ http://www.scielo.br/scielo.php?script=sci_arttext\&pid=S151797022005000200008\&lng=en\&nrm $=$ iso $>$. Acesso em: 25 jun.2007.

TRIVINÕS, A.N.S. Introdução à pesquisa em Ciências Sociais: a pesquisa qualitativa em educação. São Paulo: Ática, 1987. 175 p.

VEIGA, A.; AMORIM, E.; BLANCO, M. Um retrato da presença da educação ambiental no ensino fundamental brasileiro: o percurso de um processo acelerado de expansão. Brasília: Instituto Nacional de Estudos e Pesquisas Educacionais Anísio Teixeira, 2005. Disponível em: $<$ http://www.publicacoes.inep.gov.br/arquivos/\{8A3C33D7-1773-4DA7-BB364F5377F280AB \} MIOLO TEXTO\%20DISCUSSÃO\%2021.pdf $>$. Acesso em: 16 set. 2006.

VEIGA-NETO, A.J. Ciência, ética e educação ambiental em um cenário pós-moderno. Educação \& Realidade, São Paulo, v. 19, n. 2, p. 141-169, jul./dez. 1994.

VIERTLER, R. Métodos antropológicos como ferramenta para estudos em etnobiologia e etnoecologia. In: AMOROZO, M.; MING, L.C.; SILVA,S.P. Encontro regional de etnologia e etnoecologia. Rio Claro: UNESP; CNPQ, 2002. p. 11-29. 
APÊNDICES 


\section{Apêndice A - Roteiros das entrevistas com os diretores ou coordenadores}

Data:

Escola:

Número de alunos do Ensino fundamental (5 à 8 séries):

1) Em que consiste o trabalho do (a) professor (a)-coordenador (a)?

2) Quanto tempo você trabalha nesta escola?

3) Quais foram os projetos temáticos desenvolvidos na escola nos últimos cinco anos?

4) Há algum trabalho desenvolvido na escola em relação à temática ambiental? Qual (is)?

5) Quando e como a escola iniciou seus trabalhos com EA?

6) Como a escola vê o trabalho desenvolvido com a EA?

7) Existe alguma orientação da direção da escola, secretária de ensino e/ou MEC para trabalhar a temática ambiental? Qual?

8) E em relação a cursos de aprimoramento para os professores?

9) E material didático para trabalhos com EA?

10) Quais são os projetos temáticos que serão desenvolvidos na escola este ano de $2006 ?$

11) Quais professores e suas respectivas disciplinas trabalham a temática ambiental em sala de aula?

12) Os trabalhos com EA são transversais na escola? Se sim, de que forma? 


\section{Apêndice B - Roteiros das entrevistas com os professores}

Data:

Escola:

Caracterização dos professores:

Nome:

Idade:

Sexo:

Formação:

Tempo de magistério:

Disciplina que leciona:

Turmas que leciona:

Há quanto tempo trabalha nesta escola:

Só trabalha nesta escola:

1) Você trata da temática ambiental em sala de aula?

De que maneira?

Em quais turmas? Por quê?

2) Quais são os conteúdos da sua disciplina que você relaciona a EA?

São ocasiões pontuais ou desenvolvidas ao longo do ano letivo?

3) Você já participou e/ou desenvolveu algum projeto de EA?

Se sim: Título do projeto:

Responsáveis (orientadores):

Instituição pertencente:

Ano:

Tempo de duração:

Temática:

Qual foi o objetivo do projeto?

Qual é sua avaliação?

Qual a sua participação na elaboração destes projetos? 
4) Existe a participação ou cooperação de outros professores na elaboração e/ou desenvolvimento dos projetos?

$\underline{\text { Se sim, }}$, de que forma foi realizado este trabalho?

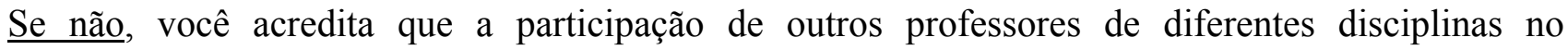
desenvolvimento de atividades relacionadas com EA seria relevante? Por quê?

5) Existe algum momento ou espaço dentro da escola para planejamentos de trabalhos entre as disciplinas?

6) Existe alguma outra atividade que gostaria de compartilhar mais detalhadamente?

7) Quais os recursos didáticos você utiliza nos trabalhos com EA?

Qual é a origem destes materiais?

A escola possui os recursos citados? Se não, onde os encontrou?

8) Descreva o início do seu trabalho com a EA: de que maneira se sentiu incentivado para iniciar atividades com EA?

9) Como você mantém-se informado em relação à EA? De que maneira os temas ambientais chegam ao seu conhecimento?

10) Existe algum tema que ainda não foi trabalhado por você, mas que gostaria de trabalhar no futuro? Qual? Por quê?

11) Quais atividades e/ou projetos que serão trabalhados em sala de aula ainda este ano na sua disciplina?

12) Você se sente satisfeito com os trabalhos de EA desenvolvidos na sua escola? Por quê?

Quais as dificuldades ou problemas encontrados na prática de EA?

O quê, na sua opinião, facilitaria o trabalho de EA?

13) Existe alguma orientação da direção da escola e/ou secretária de ensino para trabalhar a temática ambiental? Qual?

Existe algum apoio da direção?

14) Você já participou de algum curso de aprimoramento e/ou especialização de EA?

(a) Se sim: Título:

Local (instituição responsável):

Ano:

Carga horária:

Temática: 
15) Qual é a sua definição de meio ambiente?

16) Você já ouviu o termo desenvolvimento sustentável?

Se sim, qual é o seu significado?

17) O que é educação para você?

18) O que é EA para você?

19) Como vê a EA na educação escolar?

20) Como vê a EA na formação do aluno?

21) Qual é o papel da escola e do professor no processo formativo do aluno? 